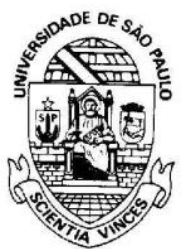

Universidade de São Paulo

Faculdade de Filosofia, Letras e Ciências Humanas

Programa de Pós-Graduação em Sociologia

\title{
A experiência da procura de trabalho. \\ Um estudo de caso
}

\section{Priscila Pereira Faria Vieira}

Dissertação apresentada ao Programa de

Pós-graduação em Sociologia da Faculdade de Filosofia, Letras e Ciências Humanas da Universidade de São Paulo para obtenção do título de Mestre em Sociologia.

Orientadora:

Prof ${ }^{a}$. Dra ${ }^{a}$ Nadya Araujo Guimarães

São Paulo

Julho 2009 


\section{Agradecimentos}

Se é verdade que, por vezes, o trabalho acadêmico é solitário, o presente estudo não seria possível sem o apoio de certas instituições e sem a interlocução e participação de uma série de pessoas importantes. Esse é o espaço para mencioná-las e registrar meus agradecimentos.

Em primeiro lugar, agradeço a minha orientadora, chefe e professora, Nadya Araujo Guimarães, que me guia desde os primeiros passos na vida acadêmica e me ensina, com seriedade e dedicação, muito sobre sociologia e pesquisa. Agradeço à sua orientação entusiasmada e carinhosa e à oportunidade de participar da pesquisa que ela coordena no Centro de Estudos da Metrópole (CEM), na qual nasceu essa investigação. Com certeza esse estudo se beneficia de um trabalho coletivo animado e comprometido.

Devo agradecer aos muitos colegas que participam ou já participaram desse grupo de trabalho, assim como aos colegas do Seminário de Orientação, organizado pela Profa. Nadya Guimarães. Tais grupos propiciaram encontros importantes à minha formação e ao desenvolvimento desse estudo. Pela interlocução e partilha de idéias e aprendizados, agradeço aos colegas: Guilherme Xavier Sobrinho, Ana Cláudia Cardoso, Ana Lúcia Ferraz, Rosi Rosendo, Isabel Georges, Luis Felipe Hirano, Milena Estorniolo, Monise Picanço, Murillo Alves de Brito, Olívia Janequine, Bárbara Vazquez, Mariel Deak, Carlos Carvalho, André Nahoum, Gustavo Taniguti, Lucas Azambuja, Miranda Zoppi e Nathália Leobas Coelho. Faço um agradecimento especial a Jonas Bicev, Flavia Consoni, Gisela Tartuce e Mônica Varasquim Pedro, que acompanharam mais de perto ou por mais tempo o presente trabalho, pela troca e companheirismo. A Uvanderson da Silva, agradeço ainda à amizade que surgiu com o dia-a-dia de trabalho e, a Paulo Henrique da Silva, pela ajuda com o processamento dos dados da RAIS.

Aos professores Álvaro Comin e Maria Filomena Gregori, agradeço por aceitarem compor a banca do exame de defesa, assim como da qualificação, ocasião na qual o trabalho se beneficiou muito de suas leituras atenciosas e comentários pertinentes. Agradeço também à Profa. Fraya Freshe, pela leitura dos capítulos empíricos e sugestões na fase final de redação da dissertação.

Registro meu agradecimento ao apoio do Programa de Pós-Graduação em Sociologia da USP. Fica um agradecimento particular à secretária Ângela que, com tanta disposição e simpatia, ajuda os alunos do Programa a resolver, com a maior eficiência, as mais diversas questões. 
Agradeço aos meus colegas de mestrado pela convivência, especialmente a Ana Carolina, Maria Carolina, Luis Enrique, Fábio, Caio e Cláudia. Esses, mais que colegas se tornaram amigos ao longo desse percurso.

Muitos amigos estiveram presentes oferecendo estímulos, dividindo a vida e tornando-a mais alegre. Thaís e Mariana viveram comigo cada fase desse processo; às duas agradeço pela paciência que só duas irmãs poderiam ter e pelo cotidiano dividido com alegria. Agradeço à Débora pela presença constante e ao Rodrigo pela cumplicidade. Paulinha, obrigada pelo prazer de uma caminhada compartilhada. À Tata, agradeço por ser a mais doce e animada companheira, e prometo um happy hour. Rafa, obrigada pelo bom humor e carinho. À Mel, agradeço pelo apoio e parceria essenciais e ao Enrico pelas lições de antropologia (e futebol e seriados de TV). Má, obrigada pela torcida. Não poderia deixar de citar os amigos Inês, Flor, Arthur, Gláucia, Flávia, Carol, Fê, Thaís Padilha, Nicholas, Rogério e Bruno, a quem agradeço pelos momentos de descontração e conversas, nas quais, inevitavelmente, vez ou outra, a pesquisa virava assunto.

Á minha família agradeço pela confiança e pelo apoio inestimável (e fundamental) ao meu trabalho e à minha formação. Agradeço ao meu pai, Márcio, por me ensinar a ter os pés no chão e à minha mãe, Léia, a olhar sempre para frente. Com certeza, qualquer trabalho que eu realize é uma síntese desses dois ensinamentos. Thaís e Vinícius, meus irmãos, obrigada por, cada vez mais, dividirem comigo o meu caminho.

Devo agradecer a todos os informantes e entrevistados. A esses, que nem imaginam o quanto colaboraram para a realização desse estudo, agradeço destacando que não sei se uma entrevista pode provocar impactos no entrevistado, mas com certeza pode ensinar muito ao pesquisador.

Por último, registro os agradecimentos ao $\mathrm{CNPq}$, à Capes e ao $\mathrm{CEM}$ pelo apoio financeiro, sem o qual essa pesquisa seria inviável. 


\title{
Resumo
}

A dissertação tem como objeto de estudo a procura de trabalho por meio de instituições do mercado de intermediação. Para desenvolver a análise assume-se que a busca de emprego não pode ser reduzida a um fenômeno econômico, baseado no cálculo racional, que une ofertantes e demandantes de vagas; nem pode ser tratada apenas como um indicador estratégico para caracterizar a situação de desemprego, como o faz uma certa sociologia. Ao contrário, assume-se que ela é uma experiência social, moral e subjetiva e que, nesse sentido, é fundamental entender os processos de interação que se dão na situação em que ela transcorre, bem como a forma como ela é vivenciada no cotidiano pelos demandantes de trabalho. A análise se baseia num estudo empírico de tipo qualitativo conduzido, entre 2005 e 2009, na região da Rua Barão de Itapetininga, no Centro de São Paulo, o principal espaço de concentração de agências de emprego da Região Metropolitana, ela mesma o maior mercado de intermediação no Brasil. Observação de tipo etnográfico, entrevistas com os agentes envolvidos na situação e análise de material documental foram as técnicas mobilizadas na análise.

Palavras-chave: procura de trabalho, desemprego, espaço, interação social, São Paulo, Brasil.

\begin{abstract}
This dissertation aims to understand the process of searching for a job by means of the labor market intermediaries. Our theoretical approach refuses both the type of economic analysis that describes it as a mere rational behavior linking job seekers and employers, and the current sociological perspective that reduces it to a crucial variable on the measurement of the unemployment situation. We assume a different sociological point of view which approaches the search for a job as a social, moral and subjective experience; in this sense, it has to be analyzed taking into account its context, as a negotiated situation, and the job seeker perceptions, experiences and discourses. The empirical research took place during four years (2005 to 2009) in the Barão de Itapetininga street, Sao Paulo downtown, the most important cluster of labor market intermediaries in São Paulo Metropolitan Region, which concentrates itself the most important segment of the Brazilian intermediation market. Ethnographic observation, interviews, analysis of documents and secondary data were the main sources in the fieldwork.
\end{abstract}

Key words: job search, unemployment, space, social interaction, Sao Paulo, Brazil 


\section{Glossário de Siglas}

CEM- Centro de Estudos da Metrópole

CONAR-Conselho Nacional de Auto-Regulamentação Publicitária

CV - Curriculum Vitae

Dieese -Departamento Intersindical de Estatística e Estudos Sócio-Econômicos

FAT -Fundo de Amparo ao Trabalhador

IBGE -Instituto Brasileiro de Geografia e Estatística

IPEA -Instituto de Pesquisa Econômica Aplicada

OIT - Organização Internacional do Trabalho

PAEP -Pesquisa de Atividade Econômica Paulista

PASSE/ABC-Pesquisa da Atividade do Setor de Serviços Empresariais do Grande ABC

PED -Pesquisa de Emprego e Desemprego

PME -Pesquisa Mensal de Emprego

RAIS -Relação Anual de Informações Sociais

RMSP -Região Metropolitana de São Paulo

Seade -Sistema Estadual de Análise de Dados

SIGAE - Sistema integrado de Gestão das Ações de Emprego

SINE -Sistema Nacional de Empregos 


\section{Sumário}

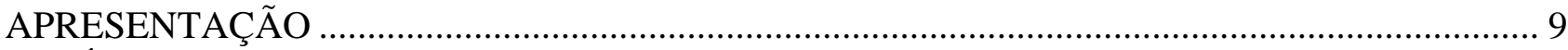

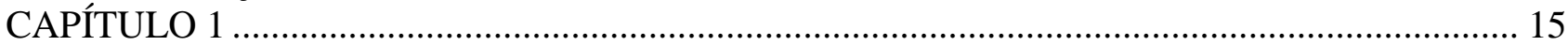

Procura de trabalho: a pertinência de um objeto de estudo ............................................................. 15

1. Do desemprego à procura de trabalho: na busca de um novo olhar......................................... 17

2.Desemprego e procura de trabalho: Brasil e Região metropolitana de São Paulo ........................ 25

3.Seguindo as pistas de estudos recentes sobre a procura de trabalho em São Paulo ...................... 31

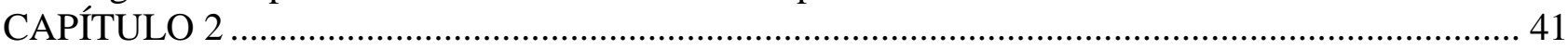

Um interlúdio teórico-metodológico: os fundamentos da construção do objeto ................................. 41

1. A construção teórico-metodológica da situação de procura. A experiência social e as situações

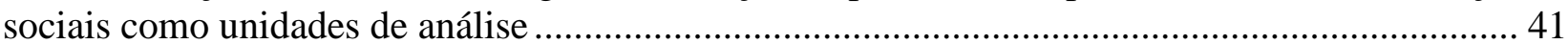

1.1. O espaço no delineamento da situação social: dimensões e processos espaciais................. 45

1.2.Os atores em interação: a construção interativa e negociada da situação social ................... 47

1.3. Condutas sociais: situadas, interativas e padronizadas ......................................................5 50

2 A construção do trabalho de campo na situação de procura: processo e procedimentos ..............53

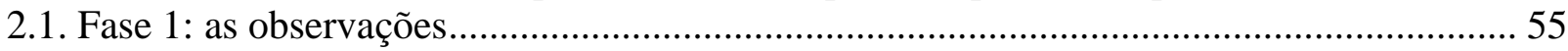

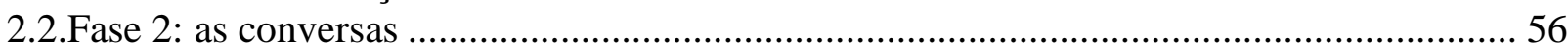

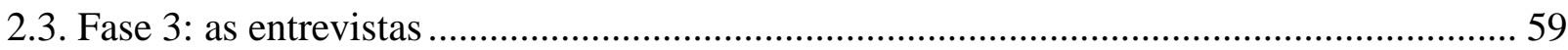

2.4. A "situação de pesquisa" na situação de procura ……………………………………….... 73

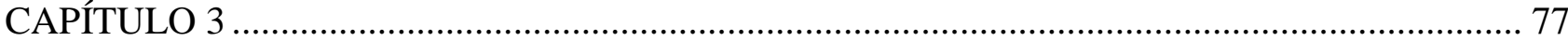

A situação de procura: espaço, instituições, atores, interações e condutas ......................................... 77

1. A procura de trabalho numa perspectiva sócio-espacial: cidade, espaço e territórios ................. 78

2. O "território da procura de trabalho": o lugar e a dinâmica............................................................ 83

3.As agências de emprego ..................................................................................................... 92

3.1. As agências da Barão de Itapetininga: características, atuação e interação de seus funcionários com os outros atores ......................................................................................... 97

3.2. As agências e a situação de procura: agências enraizadas na situação e agências

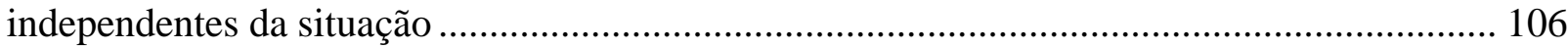

4. Os serviços correlatos à procura de trabalho: o "mercado de condutas" ................................... 110

4.1. Confecção e cópias de currículos …………………………………………………........ 111

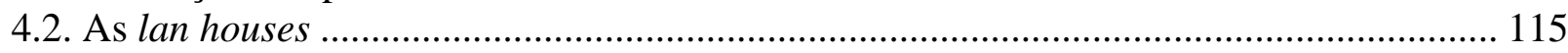

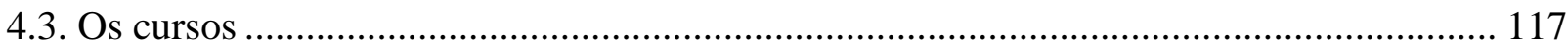

4.4. Os outros (e múltiplos) serviços................................................................................... 119

5. Os plaqueiros: os intermediadores entre as agências e os demandantes .................................. 122

5.1. Atividades e práticas dos plaqueiros ................................................................................ 123

5.2.Divulgadores, receptores e captadores: funções, interações e performances...................... 127

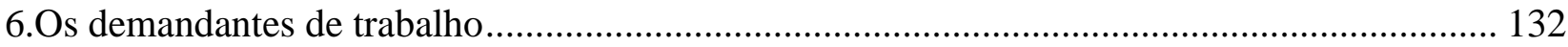

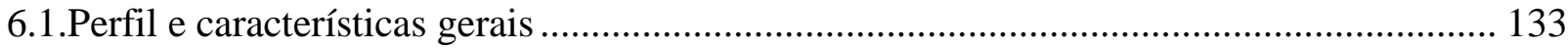

6.2.O demandante na situação: atuação, interação e conduta .................................................. 137

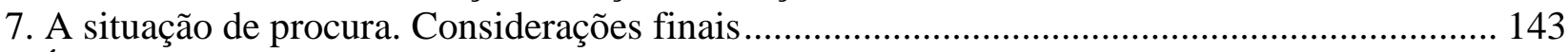

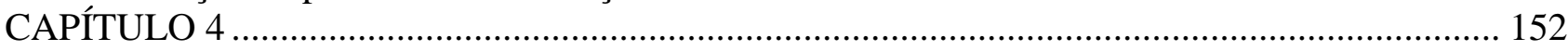

Os demandantes e a experiência da procura de trabalho................................................................. 152

1. Características sociais, expectativas e dificuldades: tipos de demandantes e de experiências de

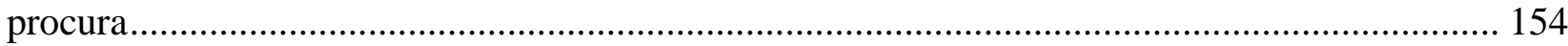

1.2. Jovens adultos em busca de um bom emprego ……………....................................... 158

2 .A procura de trabalho e as outras dimensões da vida social .................................................... 168 
2.1. Conduta social do demandante de trabalho: construção múltipla ................................ 168

2.2. A experiência da procura de trabalho: uma experiência múltipla ................................... 176

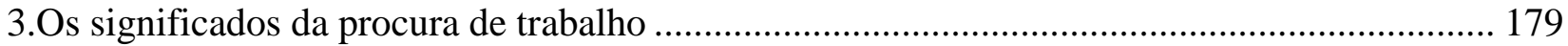

3.1 - Legitimação social e manipulação de estigmas .......................................................... 180

3.2 - "Quem procura acha" ........................................................................................... 182

3.3 - Sensação de autonomia e controle sobre a própria trajetória ....................................... 182

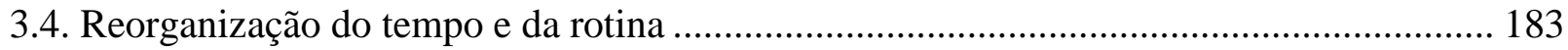

3.5. Recuperação da dimensão pública da vida social ........................................................ 183

3.6. Renovação da esperança e das expectativas ............................................................. 184

4.A situação de procura e a experiência social da procura de trabalho: considerações finais ..... 184

CONSIDERAÇÕES FINAIS ..................................................................................... 188

A experiência da procura de trabalho a aprtir de um estudo de caso .......................................... 188

1. A procura de trabalho e os processos micro-sociológicos .................................................... 190

2. A vivência da procura de trabalho: elementos sociais, morais e subjetivos ......................... 196

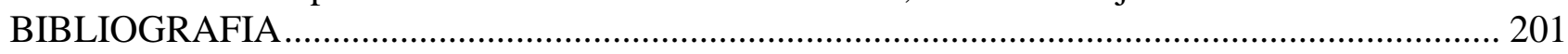

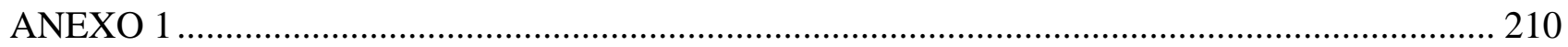

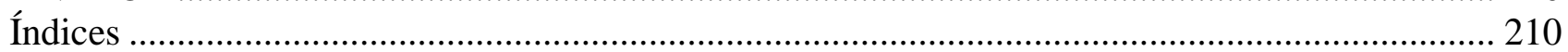

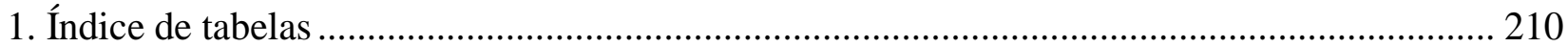

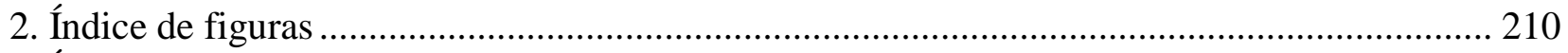

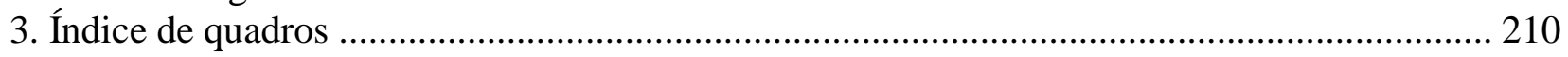




\section{APRESENTAÇÃO}

Essa pesquisa se propõe a estudar a experiência da procura de trabalho. Tal perspectiva importa não apenas porque a existência da procura é a variável definidora da condição de desempregado, mas por se tratar de um objeto relevante que, conquanto pouco estudado, desvenda muito sobre o trabalho hoje. Ainda que o interesse acadêmico pelo tema do desemprego seja crescente, pouca atenção tem sido dedicada à questão da busca de ocupação. Esse estudo pretende, por isso mesmo, argüir da pertinência sociológica de se tomar a procura como um objeto em si. No esforço de avançar no entendimento desse objeto, essa pesquisa se dedica a analisar a experiência da procura de trabalho. A pertinência dessa abordagem pode ser argumentada tanto através da ausência de trabalhos desse tipo na produção acadêmica quanto pelas interessantes e relevantes questões que ela permitiria analisar. Por isso mesmo o ponto de partida dessa investigação não foi o das estatísticas agregadas e nem mesmo o das características do indivíduo à procura de trabalho, mas o da situação de procura de trabalho.

Parte-se de uma idéia central, a saber, a de que a procura de trabalho é uma experiência social que se organiza segundo um variado repertório de situações socialmente construídas, as quais têm seus vocabulários e espaços cognitivos próprios. Situações, tal como aqui se entende, são episódios da vida pública, cotidiana e trivial. Nesses episódios ocorrem interações revestidas de lógica e de sentidos próprios ao contexto em que transcorrem; nelas se reconstrói cotidianamente a natureza dessa mesma situação. Numa situação, o indivíduo se apresenta diante dos outros, estabelece interações e, a partir do desempenho de condutas sociais, próprias a cada situação, tende a incorporar e a reafirmar, mas também a reinterpretar, um conjunto de valores e de representações sociais. Nesse sentido, pode-se afirmar que as condutas sociais são situadas ao mesmo tempo em

que as situações sociais são constituídas das condutas sociais desempenhadas pelos atores em interação, os quais orientam a sua conduta tendo também em conta as características do espaço em que a situação transcorre.

Assim, neste estudo, e seguindo a inspiração dos interacionistas, toma-se a situação social como unidade de análise, sabendo que esta é apenas uma dentre as muitas possíveis maneiras de recompor a experiência social. Como unidade de análise, cada situação social tem uma dinâmica própria e interna, que a torna uma unidade sociologicamente significativa; entretanto, por ser parte de uma experiência social mais ampla, mantém relações de contato com outras situações sociais e com dimensões macro-sociológicas. Desse modo, a experiência social da procura de trabalho seria 
constituída pela vivência de diversas e distintas situações sociais por parte dos demandantes. Tendo isso em mente, partimos do estudo de uma dentre várias possíveis situações sociais de procura para, captando parcela da experiência social da procura de trabalho, entendê-la um pouco melhor. A intenção aqui é analisar a experiência da procura de trabalho a partir da forma como ela é vivida num determinado local, num determinado momento, envolvendo determinados atores que, em parte são transitórios e em parte são fixos. Por isso mesmo, não é propriamente o espaço a unidade de análise do estudo proposto, nem mesmo o mercado de intermediação de mão de obra, nem tampouco os indivíduos singulares em sua procura de trabalho. A intenção é apreender parte da experiência da vida social tal como ela é construída na situação social em que todos esses elementos atuam; vale dizer, importa a situação de procura de trabalho e sua vivência. Busca-se entender a constituição daquela situação específica de procura a partir de seus elementos básicos e também captar, a partir dessa situação, achados sobre outras dimensões da experiência social da procura de trabalho, tal como vivida pelos demandantes, que são aqueles que realizam a atividade de busca de ocupação, sejam eles pessoas desempregadas ou não.

As noções que pautam o presente trabalho foram apropriadas de um conjunto de autores que são comumente rotulados de "interacionistas", tais como Mead, Blumer, Goffman e Strauss ${ }^{1}$; particularmente influentes na construção do argumento foram os dois últimos. Sem entrar na discussão sobre a constituição (ou não) de um campo intelectual "interacionista" que fosse uniforme, coerente e coeso, mas também sem ignorá-la, a intenção é, antes, apropriar, de forma seletiva, as noções e conceitos que, cunhados ou aprimorados por esses autores, convergem com os propósitos desse estudo. Sem essencializar nem desconsiderar as diferenças entre os autores relacionados ao chamado "interacionismo simbólico", faz-se uso de noções e conceitos que contribuem para a construção analítica requerida para a abordagem que se pretende desenvolver no presente trabalho. Por certo, essas inspirações e orientações não esgotam o escopo de questões e conceitos trazidos por cada um desses autores; a apropriação foi, por assim dizer, seletiva, na medida da sua contribuição para a construção das referências teórico-metodológicas que dão base a essa investigação, uma vez que sua principal preocupação era estudar a micro-construção da vida social. O constante cuidado com os métodos qualitativos e a preocupação em legitimá-los e

\footnotetext{
1 Tal como apontam muitos críticos e estudiosos (Alexander, 1987,1987-b; Berger, 1986; Fine, 1993; Joas, 1999; Joseph, 2000; Maines, 1977, 1979; Musolf, 1992; O’Toole 1979, Stryker, 1987; Velho, 2002; Willians, 1986), Goffman e Strauss conseguiram lapidar noções básicas ao enfoque proposto por Mead e Blumer, introduzindo questões ligadas ao poder, à economia e à ordem estrutural; sem contar a sua constante preocupação em articular os níveis macro e micro da vida social.
} 
aperfeiçoá-los, a intenção de propor uma nova articulação entre agência e estrutura a partir do estudo da vida cotidiana, tanto quanto a disposição em dialogar com a antropologia e a psicologia social, são, todas essas, características marcantes no interacionismo e que serviram de inspiração para o empreendimento que aqui se apresenta.

Ao captar a vivência da procura em sua dimensão prática e cotidiana, buscou-se não cair numa perspectiva psicologizante e nem oferecer apenas uma localização decorativa dos processos macroestruturais, mas bem articular esses elementos. Este foi, sem dúvida, o maior desafio enfrentado pela pesquisa. Para ultrapassá-lo, assumiu-se a necessidade de "desnaturalizar" a experiência da procura, entendendo-a como socialmente construída. Até porque a procura de trabalho pode se dar através de diversas estratégias, como por meio de jornais, internet, prospecção direta com apresentação espontânea junto às firmas, contatos pessoais nutridos por redes sociais e instituições do mercado de intermediação de mão-de-obra, como as agências de emprego. Essas diferentes estratégias de saída do desemprego são acionadas pelos indivíduos, que formulam escolhas, estabelecem prioridades e, assim fazendo, conformam as diferentes situações de procura de trabalho; e todas elas são contextos sociais ricos para a análise sociológica, comportando variados atores, práticas, representações e resultados.

Tendo a situação de trabalho como recorte e ponto de partida analítico, a pesquisa pretende chegar, ao final, ao entendimento da experiência da procura de trabalho tal como vivida pelo demandante de emprego, aquele que está à procura de uma oportunidade. Assim focalizada, a análise tem como objetivo entender a constituição daquela situação tendo em conta a sua dinâmica interna e os seus elementos constitutivos, mas também as suas membranas de contato com outras dimensões e fenômenos sociais.

Entretanto, o estudo aqui apresentado tem a pretensão de ser apenas um exercício sociológico, baseado na análise de uma situação de procura de trabalho muito específica. Foi escolhido um caso que permitiria a exploração de diversas questões referentes à vivência do processo de procura de trabalho. Para tal, foi realizado um estudo empírico no principal espaço de procura de trabalho da metrópole paulista: o entorno da Rua Barão de Itapetininga, no Centro da cidade de São Paulo. Tal espaço se caracteriza por congregar a maior concentração de agências privadas de emprego da região metropolitana; nele se localiza o maior cluster de intermediação de mão-de-obra da cidade (Guimarães, 2007-c, 2007-d), capaz de atrair um incrível e diverso volume de pessoas em busca de trabalho. Não sem razão é popularmente conhecido como a "rua do emprego". Outra importante característica do espaço é a multiplicidade de atores, práticas e processos que ali se apresentam, os 
quais operam na constituição de uma "situação social" com elevada potencialidade para desvendar muito sobre o processo de procura de trabalho. Neste espaço foi realizado um estudo qualitativo, de tipo etnográfico, voltado a entender melhor o processo através do qual convergem, ao final, uma vaga de trabalho e um candidato. Observações sistemáticas, aliadas a depoimentos colhidos através de relatos informais ou de entrevistas, foram as principais fontes para a construção do trabalho empírico realizado.

A presente dissertação sistematiza os achados da pesquisa, organizando-os em quatro capítulos principais, aos quais se somam esta apresentação e uma seção de considerações finais.

O primeiro capítulo apresenta o objeto de interesse analítico, a procura de trabalho, destacando como um fenômeno socialmente tão relevante num contexto marcado pelo desemprego, pode ser tornado num problema de pesquisa, constituindo-se em um objeto pertinente por preencher lacunas analíticas que persistem na produção acadêmica da sociologia. Em diálogo com a sociologia do trabalho, evidencia-se que, embora o fenômeno do desemprego tenha sido crescentemente incorporado à agenda da disciplina, dando lugar a reivindicações pela pertinência de uma sociologia do desemprego (Ledrut, 1966; Demazière, 1995; Guimarães, 2002), a procura de trabalho foi apenas marginalmente considerada. Nesse diálogo, tenta-se explorar tanto as lacunas quanto as questões potencialmente interessantes no que diz respeito a esse campo temático. Seguindo pistas de alguns poucos estudos que se dedicaram ao tema, seja no quadro da sociologia do desemprego, seja no âmbito da sociologia econômica, apresenta-se a perspectiva através da qual a procura de trabalho será aqui analisada, reforçando a pertinência em fazê-lo. O capítulo também busca contextualizar a procura de trabalho hoje, destacando algumas tendências do mercado de trabalho no que se refere ao desemprego e às variáveis que medem procura, tanto para o Brasil quanto para a região metropolitana de São Paulo; os dados apresentados deixarão entrever a importância e oportunidade de se fazer também um investimento analítico de tipo qualitativo para melhor elucidar o fenômeno. Por fim, seguindo as pistas de algumas pesquisas recentes sobre a procura de trabalho na metrópole paulista, o capitulo se encerrará argüindo da pertinência de estudos sobre situações de procura, e procurará justificar a escolha do caso que será examinado no curso da dissertação.

Uma vez argumentada a pertinência do objeto de pesquisa, da perspectiva analítica, do recorte empírico e do caso escolhido, o segundo capítulo se dedicará à construção do problema de pesquisa, apresentando as bases teórico-metodológicas da investigação e o desenho da pesquisa de campo. Partindo do princípio de que essas escolhas não são naturais nem triviais, esse capítulo se dedicará a explicitar os conceitos e noções que fundamentam um estudo sobre a experiência da procura através 
da análise de situações. Apresenta-se a discussão sociológica de natureza conceitual que habilita a noção de "situação social" como unidade de análise para a experiência social; aqui, fazendo uso das contribuições do interacionismo simbólico serão o esteio principal para a fundamentação do argumento. Na seqüência, apresenta-se o conjunto de elementos analíticos de valor estratégico para bem descrever e interpretar situações social - espaço, atores em interação e condutas sociais -, procurando mostrar ao leitor como tais elementos foram tomados em conta, norteando, a construção da pesquisa de campo e como foram mobilizados na análise. Finalmente, o capitulo se deterá sobre o modo como a informação empírica foi obtida, tratando detalhadamente dos processos e dos procedimentos do trabalho de campo.

O terceiro capítulo, de caráter empírico, tem a intenção de apresentar, descrever e analisar a situação de procura estudada. Isso se fará através da análise de sua dinâmica e de seus elementos constitutivos. Buscar-se-á entender a constituição de uma situação de procura para nele captar os elementos sociais que estão em jogo no processo de busca de ocupação. Primeiramente, apresentarse-á o espaço em que a situação de procura se desenvolve. Sendo o espaço uma das dimensões constitutivas da situação, faz-se sua descrição apoiada em categorias sócio-espaciais e em uma discussão sócio-antropológica. O espaço é analisado através da forma como é apropriado pelos atores e das características físicas que condicionam a dinâmica da situação. Através do mapeamento do espaço foi possível identificar os atores e interações determinantes daquela situação de procura, os quais serão descritos na seqüência do capítulo. Assim, os atores, investidos de suas condutas sociais, em interação e fazendo uso do espaço, dão corpo a uma outra dimensão constitutiva da situação de procura, na qual esse capítulo se concentra. As interações, as performances, as práticas, os códigos, as negociações e as condutas serão as categorias sociológicas mobilizadas na análise. Buscar-se-á compreender as relações e os códigos sociais que pautam essa vivência situada de procura de trabalho. Ao final do desenvolvimento deste capítulo, procurar-se-á evidenciar a constituição da situação de procura através de sua lógica interna, mas também explorar as membranas que a articulam a outras situações e a outras dimensões sociais, de natureza micro ou macro. Com isso, acredita-se poder avançar no conhecimento dos processos sociais que pautam a atividade da procura.

O quarto capítulo se propõe a tratar mais de perto, e ainda de maneira exploratória, os elementos da experiência social da procura de trabalho, tal como a mesma é vivida pelos demandantes, tomando por base seus próprios discursos. Não sem razão, já que ele é o ator privilegiado da análise, por ser aquele que procura um emprego e que, por isso mesmo, vivencia a 
experiência da procura de trabalho. Para explorar tal experiência, o capítulo trabalhará com três dos seus elementos constituintes e que a análise da situação investigada permitiu apontar, quais sejam: o contexto social e características sociais dos demandantes, a articulação da vivência da procura com outras vivências sociais e os significados sociais da atividade de procura de trabalho. Tentar-se-á demonstrar que esses elementos engendram diferentes experiências de busca e acabam por condicionar a forma como a situação é vivenciada pelos demandantes. Ao longo do capítulo tenta-se também explicitar sensações e sentimentos típicos dessa experiência social, explorando a dimensão do vivido.

Por fim, há uma seção de Considerações Finais, que tenta explicitar e articular achados e análises, assim como apresentar linhas de continuidade para o trabalho aqui iniciado. Respeitando os limites exploratórios desse exercício, nessa última seção faz-se o esforço de destacar dois eixos nos quais se acredita que foi possível avançar na compreensão sobre a experiência da procura de trabalho, quais sejam: os processos micro-sociológicos que regem a atividade de procura assim como parte dos constrangimentos, significados sociais e sentimentos que compõem sua vivência. 


\section{CAPÍTULO 1}

\section{Procura de trabalho: a pertinência de um objeto de estudo}

Este capítulo é uma tentativa de explicitar a pertinência da procura de trabalho como objeto de estudo, destacando as lacunas deixadas pela produção acadêmica, levantando questões analíticas que podem ser exploradas e delineando a perspectiva a partir da qual essa investigação foi realizada.

Convém inicia-lo explicitando que esta pesquisa tem um partido, qual seja, o de assumir que um estudo de tipo qualitativo pode ter elevado valor heurístico quando se quer tratar a procura de trabalho enquanto uma experiência social. Assim, aqui se argumenta a pertinência de observar a procura de trabalho a partir não de seus números, mas da forma como as pessoas a vivem; ou seja, como uma realidade engendrada por relações sociais, códigos, práticas, condutas, significados sociais e subjetividades. Cada contexto de procura cria uma conjunção diferenciada desses elementos. Entende-se aqui que cada contexto de busca, constituído desses elementos e dotado de uma lógica interna, é uma situação de procura diferenciada. Nesse sentido, o objetivo deste estudo é fazer uma pesquisa qualitativa focada em um contexto de busca - situado em um determinado espaço da cidade de São Paulo, envolvendo determinados tipos de instituições e de atores - para tratar, mesmo que de forma exploratória, questões referentes à procura de trabalho ainda pouco desenvolvidas pela sociologia.

Ainda que o esforço aqui realizado seja o de argumentar em favor da procura de trabalho como um objeto em si, é inegável que ela é parte constitutiva do fenômeno do desemprego, tanto no que diz respeito às medidas e estatísticas, quanto no que diz respeito à vida dos desempregados. Assim, este será o ponto de partida na reflexão do capítulo.

Tradicionalmente o desemprego é definido como ausência temporária de trabalho que deve vir

associada à procura regular de atividade ocupacional. É a procura de trabalho que normativa e administrativamente diferencia um trabalhador desempregado de uma pessoa inativa, constituindose, portanto, na variável fundamental da construção das taxas de desemprego e atividade. Por ser uma das variáveis definidoras da condição da situação de desemprego, a busca de ocupação já seria objeto analítico suficientemente relevante.

Entretanto, ainda que a procura de trabalho seja, via de regra, tratada apenas como dimensão constitutiva das medidas de desemprego, é preciso ressaltar que pode haver busca de emprego mesmo por parte de trabalhadores empregados. A procura de trabalho não está, assim, obrigatoriamente associada ao desemprego; pode também estar associada à busca de uma nova 
ocupação. Ou seja, independentemente da condição de desemprego ou de ocupação, ela constitui um processo social em si mesmo. Aquele que busca uma oportunidade ocupacional, seja ele desempregado ou não, é o demandante de trabalho, figura central no desenvolvimento dessa investigação.

A sociologia do trabalho muito pouco investiu no tratamento da busca de ocupação. Mesmo se encarada como constitutiva de situações de desemprego ou de transição para nova ocupação, tem sido um objeto pouco explorado. Quando abordada, é tratada apenas como elemento definidor da situação de desemprego, e assim, uma série de questões analíticas intrínsecas à própria procura deixam de ser exploradas. Daí porque avançar teoricamente no tema requereu trata-lo através do diálogo não apenas com este ramo da sociologia, mas com outros, trazendo à baila, como interlocutores, autores ligados à sociologia do desemprego e à sociologia econômica. Nesse diálogo pretende-se explorar de que forma a procura de trabalho foi abordada e apontar onde ela não foi tratada, explicitando as lacunas sobre esse assunto na literatura ${ }^{2}$.

Para dar consequiência a seus objetivos, este capítulo está divido em três partes. Ele se inicia tratando do fenômeno do desemprego, para recompor brevemente o movimento de sua incorporação analítica pela agenda da sociologia. Concomitantemente à apresentação dessa discussão faz-se o esforço de chamar a atenção para a forma como a procura de trabalho é tratada, assim como para as lacunas que persistem nessas abordagens. O principal objetivo desse tópico é argumentar em favor de tornar a procura de trabalho um objeto analítico e empírico, ressaltando a insuficiência de estudos sobre essa questão e chamando a atenção para a riqueza de pontos interessantes que os poucos estudos realizados já puderam apontar. Com base nas lacunas e nas questões potencialmente relevantes, apresenta-se a abordagem através da qual a procura de trabalho é aqui investigada. Argumenta-se em favor de olhar essa questão através da perspectiva da "experiência de procura", principalmente através da forma como ela é vivida na prática pelos demandantes de trabalho e a partir de diferentes situações de procura.

Para realizar esse empreendimento foi escolhida uma situação espacialmente delimitada na cidade de São Paulo. Assim, a segunda parte do capítulo tem o intuito de contextualizar a realidade empírica investigada, apresentando as configurações recentes do mercado de trabalho brasileiro e da

\footnotetext{
${ }^{2}$ É importante registrar que entrar no tema a partir da discussão sobre desemprego representou um grande desafio, devido à grande quantidade de questões relacionadas a este tema caro à pesquisa, o desemprego, os quais não puderam ser aqui aprofundados. Reconhece-se também a passagem breve por discussões densas e até clássicas no que diz respeito à mercado de trabalho e desemprego, sob a alegação de que elas importam aqui à medida que conduzem até o objeto analítico da pesquisa, que é a procura de trabalho.
} 
região metropolitana de São Paulo, explorando especialmente as características e mudanças nos padrões de desemprego e procura de trabalho. Apresentadas essas características dos contextos brasileiro e paulista, a importância de tomar a procura como um objeto de pesquisa fica mais evidente. Esse tópico pretende não só colocar sobre a mesa de discussão as estatísticas sobre desemprego e procura de trabalho no Brasil e na metrópole paulista como chamar atenção para o fato de que estudos sobre busca de ocupação nesses contextos são especialmente importantes, reforçando, assim, o argumento geral do capítulo.

Apresentadas, no primeiro tópico, as razões que tornam a procura um objeto pertinente de pesquisa, a perspectiva através da qual se pretende aqui explora-lo e, no segundo, as características mais gerais de contextualização da realidade empírica investigada, o terceiro tópico se dedica à apresentação e justificativa do recorte empírico eleito para esse estudo de caso. Essa delimitação do objeto é justificada através de achados de um conjunto de estudos recentes sobre busca de trabalho, no bojo do qual se insere essa investigação. Partindo de avanços desses trabalhos, foi possível atentar para as potencialidades de tomar uma situação de procura espacialmente delimitada (em torno de um cluster de agências de emprego), como recorte empírico e unidade de análise. Tenta-se explicitar as razões que levaram a esse recorte e justificar a escolha de um espaço de procura de trabalho na metrópole, entre outros possíveis, para ser investigado. Nesse espaço se delineia a situação de procura de trabalho analisada nesse estudo de caso. Um dos objetivos do terceiro tópico é, portanto, demonstrar a pertinência do estudo desse caso específico. E, com isso, acredita-se estaria cumprido o objetivo desse capítulo, qual seja, o de evidenciar a pertinência do objeto de estudo, (a procura de trabalho), a perspectiva através da qual esse objeto é tratado (a experiência da procura), o recorte empírico delimitado (uma situação de procura) e o caso escolhido (a situação de procura no cluster de intermediação de trabalho do Centro da cidade de São Paulo). Com base nessa construção analítica e empírica é que esse estudo busca um novo olhar sobre a procura de trabalho.

\section{Do desemprego à procura de trabalho: na busca de um novo olhar}

Se a procura de ocupação supõe, na imensa maioria dos casos, a ausência de trabalho (ainda que, como vimos acima, também possa ser movida pelo desejo de encontrar um trabalho melhor), não é descabido começar a refletir sobre a mesma tomando a porta de entrada habitualmente 
empregada pela literatura no tratamento do tema, ou seja, o fenômeno do desemprego. Por aqui iniciaremos para chegar ao nosso objeto.

O presente estudo norteia-se pela idéia de que a complexidade do fenômeno do desemprego não permite abordá-lo sob uma única ótica analítica - seja ela econômica, histórica, sociológica, psicológica ou política - sem risco de reducionismo ou superficialidade; e pelo reconhecimento apesar de ser este um estudo inspirado na micro-sociologia - de que é fundamental assegurar a interface com as dimensões macro sociais dessa questão.

O desemprego passa a entrar na pauta do debate intelectual e governamental a partir do século XX, tornando-se uma questão social, de fato (Castel, 2005). Mesmo se configurando como "questão social", até meados do século passado a questão do desemprego foi alvo quase exclusivo da economia, envolta no clássico debate entre os neoclássicos e os keynesianos ${ }^{3}$. A partir de 1930, quando o modelo neoclássico pareceu esgotar-se e a explicação keynesiana ganhou espaço, o desemprego passa a ser visto como uma falha do sistema econômico e como um risco à coesão social, surgindo assim o reconhecimento da necessidade de medidas de intervenção nos mercados por parte dos governos. Após a crise de 1930, surgem as políticas de mercado de trabalho nos chamados países de economia desenvolvida. Essas políticas públicas de emprego se desenvolveram lentamente na esteira da concretização do Estado de Bem Estar ${ }^{4}$.

Porém, como Castel (2005) corretamente chama atenção, esse tipo de proteção ao desemprego baseou-se numa concepção de sociedade e de Estado que hoje estão, ambos, abalados. O desemprego, classicamente definido como uma situação transitória e ocasional nas trajetórias de trabalho tem se tornado um fenômeno inerente ao mercado de trabalho, especialmente quando emergem o desemprego de longa duração e o desemprego recorrente. Essas novas formas, por sua vez, dificultaram a continuidade da proteção social tal como antes talhada, pelo substancial aumento dos custos de financiamento de tais políticas. Desse modo, ao longo do século XX, o desemprego tornou-se um problema social e um desafio intelectual. E, na esteira desse movimento, ele adquire também status de questão sociológica.

$\mathrm{Na}$ sociologia, por um longo período, o trabalho se constituía no tema analiticamente relevante; o desemprego era então apenas um tema marginal. Nas últimas décadas, porém, as

\footnotetext{
3 Para mais detalhes sobre as duas tradições do pensamento econômico ver Amadeo \&Dutt, 1994; Keynes, 1936; Mankiw, 1995.

${ }^{4}$ Para mais detalhes sobre as políticas públicas de emprego ver: Barbosa \& Moretto, 1998; Cacciamali, 2005. As políticas de emprego são aquelas que têm ação direta e explicita sobre a oferta de trabalho, podem agir tanto sobre a oferta quanto sobre a demanda de trabalho e podem ser divididas em políticas ativas e passivas. A intermediação pública de mão de obra, por exemplo, pode ser considerada política pública ativa.
} 
sociedades vêm experimentando, e de forma acentuada, um conjunto de mudanças no mercado e nas relações de trabalho. Entre as mudanças mais destacadas pela literatura sobressaem: o acentuado aumento dos níveis e da duração do desemprego, a flexibilização das relações contratuais de trabalho, o aumento da terceirização e da subcontratação, a diminuição dos postos de trabalho para o operariado industrial tradicional, o crescimento dos postos na área de serviços e o aumento da elasticidade da demanda de trabalho, efeito da globalização nos mercados de trabalho. (Offe, 1989; Demazière, 2006; Maruani e Reynaud, 1993; Freyssinet, 1984; Antunes, 1999; Guimarães, 2004; Singer, 2000; Castel, 2005; Rodrik,1997; Dedecca, 1996; Baltar \& Proni, 1996). Nesse mesmo período, houve um aumento significativo do interesse sociológico pelo tema do desemprego.

O mundo acadêmico (especialmente o europeu, onde a norma do trabalho estável e protegido e as políticas sociais para fazer face às incertezas foram certamente mais desenvolvidas) passou se debruçar crescentemente sobre o fenômeno do desemprego. Identificou-se uma nova configuração do fenômeno, que se caracterizaria não só por seu aumento de volume - do número de desempregados - mas também pelo aumento do tempo de duração de tal situação, o "desemprego de longa duração" (Demazière, 2006; Maruani e Reynaud, 1993). Além disso, identificou-se que a trajetória profissional dos indivíduos passava a estar marcada, com freqüência cada vez maior, pela recorrência do desemprego (Freyssinet, 1984; Guimarães, 2002). Assim, além de uma diversificação das modalidades de ocupação e de relações contratuais de trabalho, houve uma significativa ampliação do volume, da duração do desemprego, mas também das formas do desemprego. Este passa ser abordado não apenas como uma situação particular e transitória, mas como uma dimensão constitutiva do mercado. A importância da nova categoria social dos "desempregados de longa duração", aliada à intensidade com que o desemprego se apresentava nas economias capitalistas, notadamente as européias continentais, até então mais caracterizadas pela proteção e regulação do trabalho, explicitou a ruptura do nexo, antes "natural", entre emprego e desemprego - o que constituía para aquelas sociedades uma grande novidade e um desafio ${ }^{5}$. Vale dizer, a saída do desemprego não se dava mais pela obtenção de um trabalho estável e protegido, mas abria caminho uma multiplicidade de formas de inserção e de utilização de trabalho. (Guimarães, 2002; Demaziére, 1995).

O movimento que levaria do trabalho ao desemprego passou a ser crescentemente investigado. $\mathrm{Na}$ Europa, e especialmente na França, os autores se apropriam do desemprego como tema de

\footnotetext{
5 Abre-se, na Europa, um amplo debate sobre as políticas públicas de apoio ao desempregado, que naquele momento tendiam a restringir a cobertura e a duração dos benefícios com a crise do Estado de Bem Estar, o qual andava pari pasu com o aumento da duração e a da recorrência do desemprego.
} 
pesquisa e como questão sociológica, reivindicando, inclusive, a pertinência de uma "sociologia do desemprego". Para completar as abordagens estatísticas e fazer face ao tratamento econômico da questão, os sociólogos sublinhavam a importância de encarar o desafio de analisar a vivência do desemprego, incorporando à agenda intelectual do campo os estudos da dimensão do vivido com respeito a esse fenômeno.

Desenvolveu-se, então, uma série de trabalhos ${ }^{6}$, em torno da experiência subjetiva e moral do desemprego, retomando experiências precursoras como o estudo realizado em Marienthal por Lazarsfeld, Yahoda e Zeizel (1981) na primeira metade do século XX. Como resultado desses estudos, vários autores têm ressaltado que essa série de transformações nas formas de trabalho determina uma profunda alteração nas formas de organização material e subjetiva da vida dos indivíduos que vendem ou têm a intenção de vender sua força de trabalho. Sabe-se, assim e com extensa literatura, que o desemprego implica mudanças na organização do cotidiano, na utilização do tempo, e que ele envolve sentimentos de injustiça, vergonha e estigmatização social, entre outros efeitos de natureza social, moral e subjetiva (Lazarsfeld, Yahoda e Zeizel, 1981; Ledrut, 1966; Demazière, 1995, 2003, 2006; Antunes,1999; Demazière, Guimarães e Sugita, 2006, Sennett, 2003; Castel, 2005, Borges, 2006). Porém, vale ressaltar, à medida que cresceu o interesse pelo movimento que leva do trabalho ao desemprego, o movimento contrário, de retorno ao trabalho foi pouquíssimo explorado e menos ainda a experiência subjetiva e moral associada à procura de trabalho. A dimensão do vivido no que diz respeito à procura de trabalho foi negligenciada mesmo nas abordagens da sociologia do desemprego que buscavam investigar as vivências e experiências sociais.

Outro aspecto central a essa sociologia do desemprego, de inspiração francesa, é o argumento de que tal fenômeno deve ser visto pela ótica sociológica como constituído e delineado por características dos contextos societais, institucionais e históricos, que dão sentido às formas subjetivas de (auto) reconhecimento. Assim, sabe-se que, enquanto categoria oficial, a condição de “desempregado" é uma classificação socialmente partilhada e, nesse sentido, o indivíduo desempregado é um ser que incorpora, (re) interpreta ou (re) constrói categorias e classificações, sintetizando símbolos e características específicas a diferentes comunidades ou contextos societais. Ou seja, a significação - tanto institucional quanto subjetiva - do desemprego varia conforme os espaços nacionais e intra-nacionais e deve ser sociologicamente considerada. Esses estudos chamam

\footnotetext{
${ }^{6}$ Para mais detalhes sobre os variados tipos de tendências teóricas e metodológicas que seguiam esses trabalhos dedicados ao desemprego ver Demaziére, 2003.
} 
a atenção para o fato que uma abordagem sociológica dessa questão deveria encarar que as fronteiras entre desemprego, atividade e inatividade são construções sociais específicas (Demaziére, 1995, 2003, 2006; Guimarães, 2002, Guimarães, Hirata, Montagner \& Sugita, 2004). A procura de trabalho é, como ressaltamos na introdução desse capítulo, fundamental ao delineamento das fronteiras entre desemprego e inatividade, mas, vale repetir, foi muito pouco explorada dentro dessa perspectiva que defende a pertinência de tomar as fronteiras entre situações no mercado de trabalho como construções sociais e subjetivas. Além disso, conquanto que tenha havido um significativo esforço de analisar sociologicamente a construção da categoria de desempregado, a categoria de demandante de trabalho só muito esporadicamente entrou na pauta desses debates.

O que se pretende ressaltar é que essa agenda de pesquisa internacional, mesmo ampliada, muito pouco se dedicou a enfrentar o movimento de saída do desemprego e os elementos analiticamente relevantes para o seu entendimento. Com efeito, se alguma literatura internacional, principalmente no âmbito da sociologia econômica, atentou para as formas de procura de trabalho, e em especial para o papel das redes sociais nesses processos (Granovetter, 1973, 1974), pouca atenção tem sido dedicada pela sociologia do trabalho ao estudo dos mecanismos acionados pelos indivíduos com vistas a obter uma nova ocupação e, menos ainda, à experiência da procura de trabalho. A importância de fazê-lo é inescapável quando levamos em conta esse recente debate internacional, antes referido, o qual tem apontado insistentemente para uma nova configuração do desemprego, especialmente nos países com experiências bem-sucedidas de proteção social institucionalizada, destacando, como expresso acima, o crescimento do desemprego de longa duração e a ampliação da recorrência de transições entre situações no mercado de trabalho (Demazière, 1995, 2006; Maruani e Reynaud, 1993; Freyssinet, 1984).

Além disso, a construção social e cognitiva, ou institucional e subjetiva, da figura do desempregado é indissociável da imagem da procura de trabalho, seja de um ponto de vista prático, seja de um ponto de vista analítico, já que é a procura o elemento chave a diferenciá-lo do inativo. Ainda mais, a procura representa um importante passo rumo à saída da situação de desemprego e, portanto, suas dinâmicas constitutivas e graus de eficiência são de extrema pertinência sociológica. Por fim, essa é também uma situação crucial do ponto de vista sociológico, pois é no momento de procura que o indivíduo assume publicamente a condição de desempregado, incorporando, de fato, tal classificação social e desempenhando um determinado papel, que corresponde a um conjunto socialmente construído de expectativas de comportamento, ou seja, uma conduta social. 
Pode-se dizer, por tudo isso, que, nos estudos sobre desemprego, é inescapável abordar, ainda que tangencialmente, a busca de ocupação. Entretanto, na maioria das analises produzidas pela sociologia do trabalho ela não é tomada como um objeto em si.

Há, no entanto, um esforço que vai no sentido contrário a esse, alguns estudos passaram do desemprego à procura de trabalho. É importante destacar, no âmbito da literatura internacional, o clássico estudo de Granovetter (1974) acima citado e, para o caso brasileiro, as recentes pesquisas de Guimarães (2006-a, 2006-b, 2007, 2007-a, 2007-b, 2007-c, 2007-d e Guimarães e Melo, 2008). Na esteira desse movimento, localiza-se o interesse dessa pesquisa.

O importante trabalho de Granovetter (1974), seminal ao desenvolvimento da chamada "nova sociologia econômica", explorou as diferentes estratégias de procura de emprego e, por meio dele, podemos ver como se delineiam situações sociais específicas, compostas por variados atores, práticas, representações e resultados. O clássico estudo Getting a job (Granovetter, 1974), tornou-se referência nesse assunto. Tal estudo dedicou substancial atenção aos métodos de obtenção de emprego, analisando como circulam as informações sobre oportunidades ocupacionais e constatou a existência de uma impressionante escassez de informação, mostrando que as informações sobre trabalho circulam com dificuldade e constatando a importância das redes sociais na procura e, principalmente, na obtenção de trabalho.

Granovetter identificou que a procura de trabalho pode se basear em três tipos de estratégia: i) estratégia formal, caracterizada pela existência de um intermediário impessoal e que prescinde de um contato prévio entre quem procura trabalho e seu provável empregador; ii) prospecção direta, expressa no ato de apresentar-se ou escrever diretamente junto a um estabelecimento, sem intermediário e sem conhecimento prévio da disponibilidade de postos de trabalho; iii) contatos pessoais e informais, que supõem a existência de algum conhecimento prévio, por meio do qual o indivíduo tem acesso pessoal ao informante. Essas estratégias não são mutuamente excludentes; pelo contrário, combinam-se.

Além desta referência clássica, não podemos deixar de registrar que alguns poucos trabalhos que se desenvolveram no bojo da sociologia do desemprego também dedicaram atenção à procura, principalmente porque esse era o elemento que fundamentava a existência de alguns movimentos sociais ou tentativas de ação coletiva dos desempregados na Europa (Demaziére, 1995, 2003). O estudo de Benoit Guilbot (1990), por exemplo, se questionava sobre o grau de atividade (ou mobilização), de autonomia (em relação ao sistema público de intermediação) e de flexibilidade das estratégias do indivíduo em procura de trabalho com a intenção de traçar perfis de desempregados. 
O resultado dessa pesquisa mostra que quando a autonomia e a mobilização são fortes, há mais chance de obtenção de emprego, independentemente da qualificação e do nível de formação.

Estudos econométricos também dedicaram atenção à procura de trabalho com o objetivo de traçar modelos matemáticos de "eficiência ótima" (Stigler, 1961; Benhabil \& Bull, 1983; Lippman \& McCall, 1976). Esses modelos levam em conta variáveis como tempo de procura, número de ofertas, pluralidade de métodos de obter informação e renda reserva e chegam à conclusão de que a intensidade da procura é o elemento mais determinante em um "modelo ótimo de procura". Benhabib e Bull (1983) argumentam que o modelo ótimo de procura é, na verdade, aquele em que a procura se dá durante o período de atividade e não durante o desemprego. Esses modelos, porém, encontram pouquíssimas evidências empíricas e deixam irresolúveis questões primárias sobre o processo de procura de trabalho. (Vishwananath, 1980).

Mas, o que há para se destacar em relação aos estudos citados acima, incluindo os trabalhos sociológicos, é que eles colocam o peso analítico na mobilização do desempregado em sua busca, sem se questionar sobre o próprio processo de procura, sobre os mecanismos e estratégias de busca ou sobre as relações e constrangimentos sociais que nela estão envolvidos. Ficaram em aberto nesses trabalhos questões como i) quais os tipos de instituições e relações sociais envolvidas em cada mecanismo de procura, ii) por que certos grupos sociais recorrem preferencialmente a um mecanismo em detrimento de outro, iii) o que está por trás dessas escolhas, iv) quais códigos e práticas sociais conformam a atividade da procura a partir de cada um desses mecanismos e v) como se constitui a dimensão do vivido no que diz respeito a essa experiência. Seria possível a formulação de uma série de outras interessantes questões, derivadas dessas, e que ainda se encontram pouco exploradas.

É certo que há um movimento recente de interesse pelas instituições de intermediação de mão de obra, o que representa uma tentativa de resposta à primeira questão referida no parágrafo acima. Com efeito, elas vem se constituindo como um elemento-chave na operação do mercado de trabalho, tornando mais complexo o seu entendimento, que deixa de ser descrito apenas como uma díade que tem de um lado o demandante de trabalho e do outro o ofertante de trabalho. A figura do agente intermediador ganha espaço nesse jogo de forças que se expressa no mercado de trabalho, formando uma tríade. (Guimarães, 2006-a 2007-d).

A literatura internacional tem se dedicado ao tratamento das instituições privadas de intermediação, à medida que esse mercado vem surpreendendo por seu crescimento em diversos países; esse movimento que inclui o Brasil vai desde a América Latina, passando pelos Estados 
Unidos, até a Europa (Koene, Purcell, 2004; Echeverría, 2001, Guimarães, 2006-a, 2007-d; Barley, Evans, Kunda, 2002). Grande parte dessas pesquisas tinha a preocupação de tentar descrever o papel desses atores na (re) inserção ocupacional. O intermediador se destacava nesses estudos como uma figura que adquiria importância crescente no mercado de trabalho, organizando a intermediação entre as necessidades cada vez mais flexíveis das empresas e a busca de novas oportunidades ocupacionais por trabalhadores. Segundo Guimarães (2006-a, 2007-d), as empresas intermediadoras representariam o outro lado da moeda do movimento de reestruturação das firmas e sua atuação no mercado de trabalho torna-se mais presente à medida que tal reestruturação se mostra mais intensa. Ou seja, o crescimento da figura do intermediador seria um dos marcos do processo de flexibilização, até porque, como essas pesquisas mostram, grande parte dessas empresas não funcionava apenas como agências de emprego, mas também contratava e terceirizava trabalho. (Guimarães, 2006-a, 2007-d; Echeverría, 2001).

Para entender o mercado de trabalho e suas relações, cada vez mais complexas, a sociologia precisou voltar seus olhos para o mercado de intermediação. Esse movimento, no entanto, estava focado nas empresas intermediadoras, em suas características e formas de operação, mas não no próprio processo de procura e nem nos demandantes, que são aqueles que realizam a busca de oportunidades.

Assim, esses estudos recentes, ainda que avancem na direção de entender mais sobre as instituições que podem estar envolvidas na procura de trabalho, também pouco dizem sobre o próprio processo de procura e sua vivência. Isso porque, afora esse movimento que se preocupa em desvendar a natureza das instituições que agem no processo de convergência entre uma vaga e um candidato, focando no emergente e crescente mercado privado de intermediação de oportunidades, há, repetimos, muitas questões pouco exploradas no que diz respeito a uma abordagem sociológica da procura de trabalho.

Isso porque a procura de trabalho é, em si mesma, uma experiência social. Nela estão envolvidos atores, instituições, práticas, relações, códigos e significados sociais muito próprios; retomando os termos da sociologia do desemprego, essa também poderia ser vista como uma experiência moral e subjetiva. Essa é, portanto, a perspectiva a partir da qual se busca entender a procura de trabalho. Além disso, a procura de trabalho envolve estratégias, processos e práticas muito peculiares e os estudos antes referidos permitem dizer que os trabalhadores têm que enfrentálos cada vez mais frequentemente e por maiores períodos de tempo. Como argumentaremos no item a seguir, isso é especialmente verdadeiro para a realidade brasileira e paulista. 
Por ora, podemos dizer que, levando em conta a relevância de estudar a busca de trabalho como uma experiência social optou-se por um estudo qualitativo em uma situação de procura para analisar o próprio processo de busca enquanto ele é vivido pelos demandantes de trabalho. Observando a vivência da procura num determinado contexto, buscamos entender mais sobre os atores, instituições, práticas, relações, códigos e significados sociais que estão envolvidos nesse processo tal como ele é vivido no cotidiano. A procura de trabalho, como mostrou Granovetter (1974) pode ser vivenciada através de vários contextos e estratégias de busca as quais podem constituir diferenciadas situações de procura. Como toda experiência social, ela é fruto de uma articulação imprecisa de vivências as quais se dão em diferentes situações sociais. Uma situação de busca de oportunidades no Centro da cidade de São Paulo foi tomada aqui como recorte empírico.

Entretanto, antes de fixar o olhar na situação de procura que será tratada neste trabalho, convém localizá-la, contextualizando em termos macro-sociológicos os padrões de desemprego e de procura de trabalho no Brasil e, mais especialmente, na Região Metropolitana de São Paulo. Quando

olhamos mais de perto o que tipifica a nossa sociedade brasileira a este respeito fica ainda mais evidente a pertinência de tornar a procura um objeto de estudo.

\section{Desemprego e procura de trabalho: Brasil e Região metropolitana de São Paulo}

A agenda temática da sociologia brasileira do trabalho não deixou de lado o fenômeno do desemprego. Contudo, nos estudos inicialmente elaborados, ele não fora percebido como um fenômeno relevante em si, mas como um elemento (central, é claro) da dinâmica de outro processo (esse sim considerado relevante), o da chamada "reestruturação produtiva". Talvez porque, à parte de uma experiência histórica de um Estado de Bem Estar, as linhas divisórias entre emprego e desemprego nunca tenham sido tão nítidas por aqui, fazendo da institucionalização do desemprego, em seus moldes tradicionais de definição, um evento fraco e recente. Isto porque em uma sociedade de industrialização tardia, como a nossa, o fenômeno não se apresenta como uma moeda de dupla face onde, de um lado, está o emprego estável e protegido e, do outro lado, o desemprego aberto e institucionalizado. A configuração de um sistema de emprego em torno a esses dois estatutos principais supunha um sólido sistema público de proteção e a universalização do assalariamento como forma de relação de trabalho. 
O mercado de trabalho brasileiro seria então historicamente caracterizado por dois aspectos importantes: pela heterogeneidade das relações de trabalho e pela instabilidade dos vínculos empregatícios. Assim, a flexibilização, que nos países europeus teve um forte impacto sobre a estabilidade do emprego, não se dá com a mesma intensidade no Brasil, já que aqui a instabilidade já era uma característica estrutural da operação do nosso mercado de trabalho. Porém, observou-se aqui nas últimas duas décadas um movimento de enxugamento dos postos de trabalho, principalmente de trabalho formal e notadamente do trabalho industrial ${ }^{7}$. $\mathrm{O}$ aumento do desemprego urbano, especialmente nas regiões metropolitanas, tem igualmente se evidenciado (Guimarães, Hirata, Montagner \& Sugita, 2004; IPEA, 2007; Chahad, 2003). Ao lado disso, é notável a distribuição desigual do risco do desemprego e das chances de localizar-se em ocupações precárias; os jovens, os negros e as mulheres estão entre os mais afetados por essas duas situações (Cacciamali e José-Silva, 2003; Dedecca, 1996, IPEA, 2007; Brandão, Watanabe, Ferreira e Montagner, 2006). Guimarães (2004) argumenta que a característica mais marcante das trajetórias profissionais, constituídas nos anos 1990, a partir da reestruturação no Brasil foi a recorrência do desemprego e a intensificação das transições de entrada e saída do mercado de trabalho, mais do que a rotatividade entre postos de trabalho num mesmo setor ou que o desemprego de longa duração.

O Instituto de Pesquisas Avançadas (IPEA) analisando o impacto das políticas públicas brasileiras no período $1995-2005^{8}$ destaca, com respeito ao desemprego: "Os níveis absolutos $e$ relativos de desemprego aumentaram, bem como a informalidade das relações de trabalho e a desproteção previdenciária esperada, enquanto os níveis reais médios de renda do trabalho e a sua distribuição pioraram" (pp. 224)9.

Ademais, o aumento da taxa de desemprego veio acompanhado de uma maior dificuldade de buscar emprego. Assim, em 1995, a Pesquisa Mensal de Emprego (IBGE) registrava um tempo médio de procura de trabalho entre 14 e 17 semanas entre os desocupados, conforme o mês; em 2002, esse tempo havia passado para o intervalo de 20 a 24 semanas $^{10}$. Rodarte e Braga (2005), analisando dados recentes da Pesquisa de Emprego e Desemprego (Seade/ Dieese) para as regiões

\footnotetext{
${ }^{7} \mathrm{O}$ ajustamento do mercado de trabalho brasileiro através do setor informal é salientada por vários autores. Para mais detalhes ver: Cacciamali e José-Silva, 2002; IPEA,2007, Singer, 2000; Chahad, 2003; Pochman, 1999, Guimarães, 2002.

${ }^{8}$ Boletim IPEA Políticas Sociais. Acompanhamento e Análise. 1995-2005. Edição Especial, 2007

${ }^{9}$ Os dados sugerem ainda que o aumento do desemprego não se deu ao mesmo tempo de uma melhora na qualidade dos postos de trabalho já existentes, mas pelo contrário, nos grupos em que o desemprego mais cresceu observou-se uma queda do grau de formalização e proteção previdenciária.

${ }^{10} \mathrm{Na}$ PME/ IBGE tal como divulgada a partir de 2003 não consta a informação sobre o tempo médio de procura de trabalho, mas sim a composição da população desocupada por faixas de tempo de procura.
} 
metropolitanas investigadas, afirmam que, a partir de 1999, é possível identificar um aumento na criação de vagas, mas que o tempo de procura por emprego permanece elevado e em ascensão. Isso denota que, dentro do movimento de reconfiguração do mercado de trabalho e do desemprego no Brasil das últimas décadas, a variável tempo de procura de trabalho se destaca por seu crescimento.

Já no que se refere à Região Metropolitana de São Paulo, apesar de ter sido considerada a metrópole paulista por muitas décadas o pólo econômico e o mercado de trabalho mais dinâmico do Brasil, esta sofreu um processo de transição que se acentuou a partir da década de 1990. Boa parte das transformações ali registradas acompanha as tendências gerais brasileiras, revelando, com mais nitidez, alguns desses processos. Os anos 1980 e 1990 permitiram observar algumas mudanças importantes na RMSP; entre elas destaca-se o forte crescimento do desemprego e aumento acentuado do tempo de procura de trabalho. (Chahad, 2003; Singer, 2000; Brandão, Watanabe, Ferreira e Montagner, 2006). Essas alterações produziram uma mudança no perfil dos ocupados na região, conforme Brandão, Watanabe, Ferreira e Montagner (2006). Os autores ressaltam um intenso fluxo entre ocupação e desemprego e de ocupados entre postos de trabalho diferentes. Essa é uma importante característica desse mercado de trabalho e vai ao encontro de uma característica mais geral do mercado de trabalho brasileiro: a instabilidade da inserção representada pelo curto tempo de duração de uma ocupação e o trânsito entre situações de ocupação, desemprego e inatividade. Porém, estudos ressaltam uma mudança no perfil desse trânsito ocupacional, que seria agora melhor caracterizado por trânsitos entre situações de desemprego, do que pelo transito entre ocupações (Guimarães, 2006-b, Guimarães, Hirata, Montagner e Sugita, 2004). Retornando à procura de trabalho, é importante ressaltar que houve no período 1995-2002 um enorme aumento do tempo médio de procura de trabalho na Região Metropolitana de São Paulo (Chahad, 2003, Guimarães, 2006-b, Guimarães, Hirata, Montagner e Sugita, 2004). Esse tempo que em 1995 era de 22 semanas passou para 51 semanas em 2002: um aumento de 150\% (Chahad, 2003).

Vemos no gráfico abaixo que o tempo de procura de trabalho continuou crescendo até 2004, quando atinge o número de 55 semanas e então começa a cair, no período de aquecimento da economia. Em 2008, o tempo médio de procura de trabalho no desemprego total na metrópole paulista foi equivalente a 42 semanas,pouco mais de dez meses. 
Figura 1.1: Evolução do Tempo Médio de Procura de Trabalho (em semanas) por tipo de desemprego na RMSP (1990-2008)

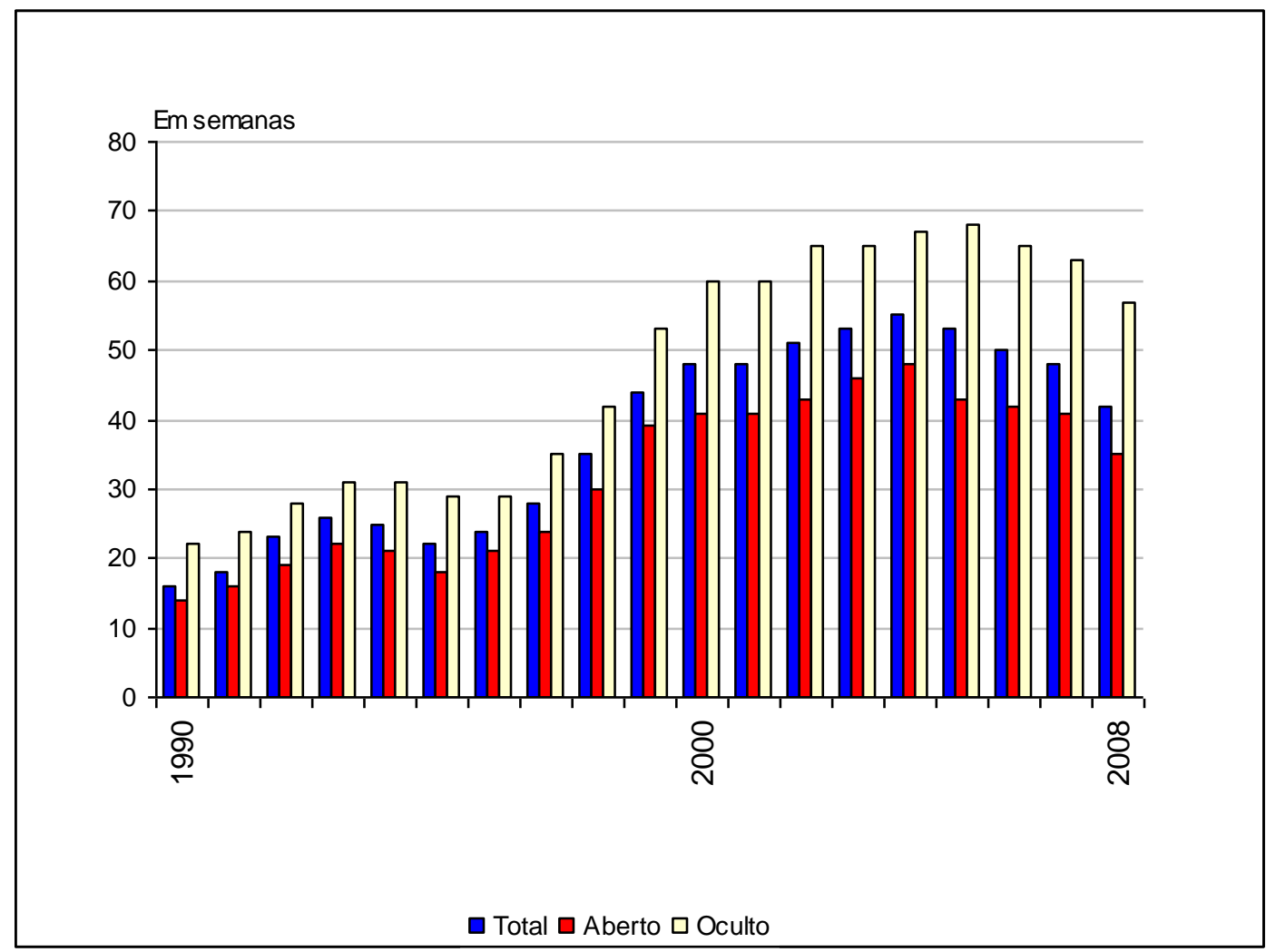

Fonte: Fundação Seade/DIEESE. Pesquisa de Emprego e Desemprego

O gráfico permite observar o notável crescimento do tempo médio dedicado a procurar trabalho ao longo dos últimos 20 anos, ainda que indique também que, nos últimos três anos, esse movimento vem apresentando uma queda gradual conquanto se mantenha bastante elevado e nem de longe retome, apesar do crescimento da economia no período, os valores do inicio da série. Ou seja, na RMSP, a procura de trabalho vem adquirindo mais espaço e importância na dinâmica do mercado de trabalho e nas trajetórias dos trabalhadores, ainda que, por aqui, os períodos de procura de trabalho possam se intercalar com ocupações precárias e com o desalento, o que torna a questão ainda mais complexa e reforça a importância de fazer da experiência da procura um objeto de pesquisa.

Ademais, o aumento do tempo de procura é um ônus tanto para o trabalhador, quanto para a sociedade, pois tal afastamento prolongado do trabalho causaria desatualização profissional por parte dos atingidos. É a "queima de capital" (Rodarte \& Braga, 2005) ou "perda de qualificação acumulada" (Guimarães, 2004), que decorre tanto do afastamento do trabalho quanto de uma inserção no mercado em uma área ou atividade diferente da que o trabalhador atuava. Outra conseqüência evidente é o empobrecimento da população em situação de desemprego, até mesmo 
porque os mecanismos estatais de proteção e auxílio a essa população não são suficientes. Em última análise, se debruçar sobre a experiência da procura de trabalho num contexto como o da metrópole paulista torna-se fundamental para se entender uma parte cada vez mais significativa e recorrente das trajetórias ocupacionais dos trabalhadores; daí a relevância de se estudar os mecanismos de saída do desemprego e as situações de procura de trabalho.

Ainda no que se refere à mensuração da procura de trabalho, em casos como o brasileiro, vê-se que esta questão pode se tornar especialmente importante. Isso porque certas características específicas do mercado de trabalho (muita heterogeneidade, grande rotatividade e baixo grau de formalização) dificultam a mensuração do desemprego segundo critérios típicos de países de capitalismo avançado. Em realidades como a nossa, a linha divisória entre o desemprego, o emprego e a inatividade não é clara e há uma grande variedade de situações intermediárias. Exatamente por isso novas categorias foram construídas de modo a melhor descrever as especificidades locais do fenômeno, a sofisticar a construção de suas medidas e a favorecer a proposição de políticas para enfrentar o problema ${ }^{11}$.

A modalidade "desemprego oculto", por exemplo, introduzida pela Pesquisa de Emprego e Desemprego (PED)12, como uma inovação frente à metodologia da Organização Internacional do Trabalho tenta dar conta dessas especificidades. No Brasil, a metodologia da PED diferencia duas formas de desemprego oculto, quais sejam: i) "desemprego oculto por trabalho precário" - definição aplicável às pessoas que realizaram, nos últimos 30 dias, algum trabalho remunerado irregular ou não-remunerado em ajuda a negócios de parentes - e que procuraram substituí-lo nos 30 dias anteriores à entrevista ou que, não tendo procurado neste período, o fizeram sem êxito até 12 meses atrás e ii) "desemprego oculto por desalento" - aplicável às pessoas sem trabalho e com necessidade de trabalhar, porém sem procura efetiva por desestímulo do mercado de trabalho ou por circunstâncias fortuitas, mas que apresentaram procura ativa, de pelo menos 15 dias, nos últimos 12

\footnotetext{
${ }^{11}$ No Brasil os institutos que medem as estatísticas referentes a mercado de trabalho usam metodologias e conceitos diferentes. (Pochman, 2007; Brandão \&Hoffman, 1996). Porém, apesar do valor heurístico das comparações é necessário ter em mente que o desemprego não significa a mesma coisa em diferentes realidades regionais e medidas universais têm dificuldade para dar conta das especificidades locais, que seriam fruto de construções societais. (Guimarães, 2002)

${ }^{12}$ No Brasil, duas grandes pesquisas produzem dados sobre mercado de trabalho e desemprego e ao fazê-lo também sobre o tempo de procura de trabalho e os mecanismos mobilizados para tal: a Pesquisa Mensal de Emprego (PME), realizada pela IBGE desde 1980 e a Pesquisa de Emprego e Desemprego (PED), realizada por uma parceria entre organismos dos governos estaduais (em São Paulo, por exemplo, pela Fundação Sistema Estadual de Análise de Dados Seade) e o Departamento Intersindical de Estatísticas e Estudos Socioeconômicos (DIEESE) desde 1984. Ambas são mensais e de tipo domiciliar. A PME é aplicada nas regiões metropolitanas de Recife, Salvador, Belo Horizonte, Rio de Janeiro, São Paulo e Porto Alegre. A PED é realizada nas Regiões metropolitanas de Salvador, Belo Horizonte, Recife, Porto Alegre, São Paulo e Distrito Federal.
} 
meses $^{13}$. A primeira subclassificação flexibiliza a condição de ausência de atividade ocupacional, enquanto a segunda flexibiliza a exigência da procura de trabalho.

Com, efeito a categoria do desemprego aberto recobria apenas os indivíduos sem qualquer tipo de trabalho e em procura regular na semana de referência. Sua adoção como medida exclusiva do desemprego só seria possível em realidades de mercados homogêneos, marcados pela prevalência da norma de assalariamento e pela existência de um sistema de proteção que subsidiava o trabalhador enquanto o mesmo procurava trabalho. Este não é o caso brasileiro; por isso mesmo, na categorização do desemprego oculto são consideradas as iniciativas de procura de trabalho que tenham se realizado em lapsos de tempo maiores, mesmo se, no momento da pesquisa, o desalento houver retirado o desempregado da sua atividade de busca de trabalho. Vê-se, assim, que a variável “tempo de procura" tem importância estratégica para a diferenciação dos tipos de desemprego ${ }^{14}$. Há aqui uma ampla discussão sobre as fronteiras entre a) desemprego oculto por trabalho precário e ocupação em trabalho precário e b) entre o desemprego oculto por desalento e a inatividade.

Como se pode notar, é grande a polêmica em torno das formas de medir o desemprego, e do modo de assegurar-se da existência de procura de trabalho. Dessa discussão o que importa ressaltar é que a procura de trabalho esteve no cerne do debate da criação de uma nova categoria de desemprego, o desemprego oculto por desalento. Porém, o debate gira, de fato, em torno do "tempo de procura" e da busca da definição do período de tempo mais adequado para definir o desemprego ou a inatividade. A procura importa apenas como um indicador, a bem medir, para diferenciar as formas do desemprego. Há muito pouca discussão a respeito dos mecanismos e processos de procura, a respeito dos métodos de procura mais eficientes, das dificuldades encontradas na procura, entre outras questões importantes, que bem poderiam ser desveladas pela combinação de abordagens quantitativas e qualitativas.

Isso porque à medida que se multiplicam as situações de desemprego dada a "recorrência do desemprego" captada por diversas pesquisas (Brandão, Watanabe, Ferreira e Montagner, 2006; Guimarães, Hirata, Montagner e Sugita, 2004; Guimarães 2004), aumenta a freqüência dos períodos de procura de trabalho nas trajetórias ocupacionais. Além disso, o tempo de procura de trabalho vem

\footnotetext{
${ }^{13}$ Definições oficiais. Ver metodologia da Pesquisa de Emprego e Desemprego (PED) no site: $\underline{\text { www.seade.gov.br }}$

${ }^{14}$ A ampliação do período de referência para a procura justifica-se pelas interrupções que podem ocorrer nas tentativas individuais de obter novo posto de trabalho, por espera de resposta para uma busca anterior de trabalho, doença ou falta de recursos.
} 
aumentando, conforme pesquisas com dados para o Brasil e para a Região Metropolitana de São Paulo (Guimarães, Hirata, Montagner e Sugita, 2004; IPEA, 2007; Rodarte e Braga, 2005). Entender a dinâmica da procura de trabalho, no nosso caso, é decisivo não apenas para melhorar as formas de mensuração do desemprego, como para compreender os processos que levam à saída do desemprego e que, mais frequentemente e por maiores períodos de tempo, estão presentes na vida dos trabalhadores.

Contextualizada a realidade empírica investigada em termos dos números mais gerais sobre desemprego e procura de trabalho, e ressaltada a pertinência de um estudo qualitativo nessa conjuntura, passamos, no item a seguir, para uma justificação e delimitação do recorte empírico das "situações de procura" e do caso escolhido para dar base a esse estudo. Prosseguimos na construção do problema de pesquisa seguindo as pistas de estudos recentes sobre o tema na RMP e situando esse trabalho no bojo desse conjunto de avanços.

\section{Seguindo as pistas de estudos recentes sobre a procura de trabalho em São Paulo}

O interesse em estudar a procura de trabalho como uma experiência social e a partir da forma como ela é vivida em uma situação de procura específica surgiu tanto pela identificação da ausência desse tipo de tratamento analítico na produção acadêmica quanto pela identificação de questões sociologicamente pertinentes e potencialmente interessantes as quais poderiam ser investigadas nesse tipo de abordagem. As lacunas na produção acadêmica já foram apresentadas, mas a identificação de questões potencialmente interessantes é devedora de recentes estudos que têm se dedicado a tratar da procura de trabalho no contexto brasileiro, especialmente no paulista. $\mathrm{O}$ desenvolvimento desses estudos permitiu vislumbrar a pertinência da investigação de situações de procura de trabalho assim como permitiu escolher uma situação de procura analiticamente interessante. Por isso, iniciamos apresentando os avanços realizados por esses trabalhos e os achados que levaram à delimitação do objeto de pesquisa aqui investigado.

Seguindo pistas de pesquisas sobre desemprego, um conjunto de estudos passou a tratar a procura de trabalho como objeto em si para avançar no entendimento dos mecanismos acionados pelos indivíduos na saída do desemprego. Esses estudos estavam pautados no conhecimento de que i) são socialmente complexos os mecanismos pelos quais se dá a convergência entre oferta e procura de trabalho, ii) é importante o papel das redes sociais nesses processos (Granovetter, 1973, 1974) e iii) o mercado de intermediação de mão-de-obra vinha assumindo por aqui importante e crescente 
papel nesse mesmo processo de convergência. Para investigar esses pontos, uma série de trabalhos foi realizada no bojo da pesquisa "À procura de trabalho: instituições do mercado e redes sociais na saída do desemprego. São Paulo numa perspectiva comparada"15, na qual se inseriu também este estudo.

Essa investigação mais ampla começou por analisar a procura de trabalho através de um olhar mais cuidadoso para o mercado de intermediação de mão-de-obra, igualmente crescente por aqui. Justificava tal ponto de partida o reconhecimento de que em condições de ampliação significativa do desemprego em contextos de reestruturação das firmas, as oportunidades se tornam opacas do ponto de vista de quem procura trabalho tanto quanto o seu preenchimento se torna de alto custo do ponto de vista da empresa contratante, que passa a externalizar boa parte das tarefas de seleção e triagem que antes estavam nos setores de gestão dos seus recursos humanos. A presença do intermediário, seu intenso crescimento nas condições de opacidade e custo assim definidas, parece um elemento decisivo para entender como oferta e demanda se cruzam, como a procura de trabalho se torna realidade. Estudos buscaram, então, entender melhor a constituição desse mercado, suas características mais marcantes, sua forma de atuação e o perfil daqueles que acorrem a essas instituições (Guimarães; 2006-a, 2006-b, 2007-a, 2007-b, 2007-c, 2007-d e Guimarães e Melo, 2008).

Esses trabalhos apontam que, no Brasil, a intermediação privada ganha mais força necessariamente à medida que a intermediação pública vai sendo consolidada e todo esse processo ganha especial vigor no curso dos anos 1990. Para a consolidação desse mercado foram decisivos: i) a intensa reestruturação econômica do período que fez aumentar o desemprego e, especialmente, o desemprego recorrente, ii) a consolidação do negócio do trabalho temporário que se fez concomitantemente a essas mudanças econômicas e seus efeitos no mercado de trabalho e iii) a montagem do atual sistema público de intermediação redesenhado com o recurso do FAT e que fortaleceu o Sistema $\mathrm{SINE}^{16}$. Ou seja, a partir desse momento há um aumento da clientela potencial

\footnotetext{
15 Trata-se de projeto de pesquisa desenvolvido no Centro de Estudos da Metrópole entre 2005 e 2008 , com financiamento do CNPq e Fapesp, sob a coordenação de Nadya Araújo Guimarães, e no qual se concebeu, como uma dimensão da análise do tema, o desenvolvimento do trabalho que deu lugar a esta dissertação. Principais resultados deste projeto estão reunidos em Guimarães, 2009.

${ }^{16} \mathrm{O}$ sistema integrado de serviços públicos voltados para o trabalho e o trabalhador é o Serviço Nacional de Emprego (SINE). Implementado em 1976, só a partir da década de 1990 passa ater uma atuação mais relevante quando passa a ser financiado por um fundo público e dirigido por um conselho tripartite (CODEFAT). As principais funções desse sistema são: intermediação de mão de obra, orientação profissional, treinamento e capacitação, implementação de programas de trabalho e elaboração de estatísticas sobre mercado de trabalho. Na década de 1990 desenvolve-se o Sistema integrado de Gestão das Ações de Emprego (SIGAE) que passa a centralizar todos os dados dos inscritos nos programas de
} 
de demandantes de trabalho para esse mercado de intermediação a medida que também aumenta o interesse do mercado de trabalho e das empresas pela contratação de temporários e terceirizados (Guimarães, 2007-a).

No que diz respeito à intermediação pública, a despeito de sua criação na década de 1970, apenas nos anos 1990, com uma definição estável de financiamento e com a operação dentro de um sistema integrado de serviços, é que essas políticas se institucionalizaram, legitimando-se como serviço relevante frente às empresas e aos trabalhadores. Porém, apesar do aumento da procura desses serviços, tanto pelas empresas quanto pelos demandantes de trabalho, até o início dos anos 2000, é considerada fraca a atuação da intermediação pública brasileira. (Cacciamali, 2005; IPEA, 2007; Guimarães, Hirata, Montagner \& Sugita, 2004).

Os estudos sugerem que, com mais força que a intermediação pública, surgiu a intermediação privada. No Brasil e, mais especificamente, na Região Metropolitana de São Paulo, um mercado de intermediação de oportunidades de trabalho consolidou-se nos anos de 1990. A metrópole paulista seria aquela em que esse mercado estaria mais solidamente constituído, destacando-se como unidade que mais concentra estabelecimentos desse tipo (Guimarães, 2007-a).

Estudos recentes sobre a configuração do mercado de intermediação de mão-de-obra paulistano mostram que essas empresas são extremamente heterogêneas e se caracterizam por operar espacialmente concentradas em clusters $^{17}$, beneficiando-se das vantagens das economias de aglomeração (Guimarães, 2007-c). Estudos qualitativos baseados em entrevistas com funcionários de algumas agências assim como trabalhos com dados administrativos como a PASSE/ABC ${ }^{18}$ e a PAEP $^{19}$, como os realizados por Pamplona (2002) e Bessa e Consoni (2007), permitem avançar ainda mais na descrição dessas empresas.

Primeiro, é possível dizer que elas podem se sub-dividir em dois grandes segmentos: empresas de grande e pequeno porte. As empresas de grande porte podem ser nacionais ou multinacionais, atuam em redes de filiais, possuem longo tempo de implantação, são filiadas a associações e sindicatos, possuem staff especializado e estratégias avançadas e diversificadas de captação de

\footnotetext{
seguro-desemprego e intermediação pública de mão - de obra numa única base de dados. Para mais detalhes sobre o SINE ver: Cacciamali, 2005; IPEA, 2007; Barbosa \& Moretto, 1998; Guimarães, 2006-b.

17 Usa-se a noção de "cluster" para chamar a atenção para o fato de que não se trata de um mero aglomerado, espacialmente localizado por razoes fortuitas, mas de uma distribuição territorial que aproveita as economias de aglomeração e cria interface entre os diferentes tipos de empreendimentos que tem lugar nesses entornos. Para maior desenvolvimento a respeito, ver Guimarães (2009).

${ }^{18}$ Pesquisa de Atividade do Setor de Serviços Empresariais (PASSE/ABC). Agência de Desenvolvimento econômico do Grande ABC/ IMES/ Seade/ Habitat (LA\&C)

${ }^{19}$ Pesquisa de Atividade Econômica Paulista . Fundação Seade.
} 
empresas-cliente e candidatos. Já as empresas de pequeno porte se caracterizam por atuar de forma local e única, muitas das vezes nos clusters de intermediação da cidade, são muito vulneráveis aos movimentos econômicos, têm alta mortalidade (principalmente por possuírem poucos clientes), não são associadas ou sindicalizadas e se caracterizam por intermediar, principalmente, vagas para trabalhos com pouca qualificação e/ ou remuneração. As empresas de menor porte, capital nacional e operação local são aquelas numericamente mais significativas, apesar de empregarem um número menor de funcionários e intermediarem um número menor de vagas (Guimarães, 2007-c; Bessa e Consoni, 2007).

Uma tendência das empresas desse mercado é ampliar o oferecimento de serviços para além da captação e seleção de mão-de-obra, investindo na contratação de estoques de mão-de-obra para alocar ou terceirizar. Paralelamente a esse movimento de diversificação dos serviços, há uma focalização em nichos do mercado de trabalho através da especialização da intermediação de vagas específicas. Por exemplo, existem empresas especializadas em intermediar vagas para estágio, vagas para trabalho doméstico, vagas na área de telemarketing e assim por diante. Assim, basicamente os fatores que caracterizam (e diferenciam entre si) as empresas do mercado de intermediação de mãode-obra são: porte, escala de operação, diversificação de serviços, propriedade do capital, enraizamento espacial, tipo de ocupação intermediada, estratégias de captura e fidelização de clientes e, por último, mecanismos de divulgação de vagas e captação de candidatos (Guimarães, 2007-d).

Um dos interessantes e importantes achados dessas investigações referentes a esse mercado em São Paulo é sua concentração espacial, como demonstra Guimarães (2006-a, 2007-d), organizandose em verdadeiros clusters em diferentes espaços da metrópole. A exploração da base RAIS ${ }^{20}$ de registros administrativos sobre empresas formalmente registradas, associada a observações sistemáticas em campo e aos dados do survey "Á procura de trabalho" 21 foi possível identificar os

\footnotetext{
20. Relação Anual de Informações Sociais (RAIS), banco de dados administrativos produzido pelo Ministério do Trabalho e Emprego com base em informações coligidas junto a empresas que estão obrigadas a informar, a cada 31 de dezembro de cada ano, sobre o plantel de funcionários formalmente registrados, indicando características de perfil do trabalhador e do tipo de contrato de trabalho; é, na verdade, um censo anual do emprego formalmente registrado e das firmas operantes no mercado, embora com os defeitos e problemas de qualidade que resultam dos registros administrativos.

${ }^{21}$ Survey “À procura de Trabalho" realizado pelo Centro de Estudos da Metrópole, em 2004, junto a uma amostra de trabalhadores em procura de trabalho, representativos dos diversos tipos de agências de emprego na Região Metropolitana de São Paulo. Foram entrevistadas 1.548 pessoas em 50 pontos diferentes de procura. Esses pontos foram estratificados segundo propriedade do estabelecimento, porte e localização na região metropolitana. Informações administrativas antes coligidas na RAIS haviam permitido constatar que os estabelecimentos do mercado de intermediação se distribuíam espacialmente na metrópole a partir de aglomerados, que operavam como verdadeiros clusters, o que foi levado em consideração para a escolha dos locais de aplicação de questionários. Para detalhes sobre o
} 
seguintes clusters na região metropolitana de São Paulo: Centro, Santo Amaro, Lapa, ABC, Guarulhos e Alphaville. Assim foi possível perceber que a procura de trabalho através de agências de emprego na metrópole paulista é uma atividade espacial e territorialmente delimitada.

Esse investimento permitiu caracterizar melhor tais clusters e vislumbrar as potencialidades analíticas de tomar esses espaços da metrópole como recortes de investigação empírica, principalmente de tipo qualitativo e etnográfico. Isso porque nesses espaços era possível observar o próprio processo de procura e seus elementos constitutivos. Esse tipo de recorte permitiria a análise da vivência da procura in loco e das relações, práticas, códigos, condutas e significados sociais que nela poderiam estar envolvidos, além da identificação dos tipos específicos de atores e instituições que comporiam cada um desses contextos territorializados de procura. Tomar os espaços de procura como unidades de análise parecia sociologicamente pertinente, o que estimulou o desenvolvimento da presente investigação.

Além de abrir essa porta analítica, o investimento de investigação dos clusters de intermediação acima referido permitiu captar suas características e identificar os perfis de demandantes que recorrem a cada um deles. Além disso, permitiu apontar que o principal cluster, por sua maior concentração e diversidade de estabelecimentos, assim como pelo poder de atração de demandantes, é aquele localizado no Centro do município de São Paulo, no qual foi realizada a investigação empírica que será apresentada.

O perfil das agências do Centro $^{22}$ é de certo modo similar ao perfil das demais agências localizadas em outros clusters importantes (ABC, Guarulhos, Alphaville etc.). O que as distingue é a maior participação das grandes agências com mais de 100 funcionários, embora quase metade das agências ali localizadas (42,9\%) sejam muito pequenas ( 0 a 4 funcionários).

desenho da pesquisa ver relatório "Á procura de trabalho: instituições de intermediação e redes sociais na saída do desemprego. São Paulo numa perspectiva comparada" (Guimarães, 2007), disponível no site: www.centrodametropole.org.br, tanto quanto Guimarães (2009).

${ }^{22}$ No cluster do Centro estão incluídas as agências localizadas nos distritos da Sé e República. 
Tabela 1.1: Distribuição das agências privadas da RMSP por porte e localização

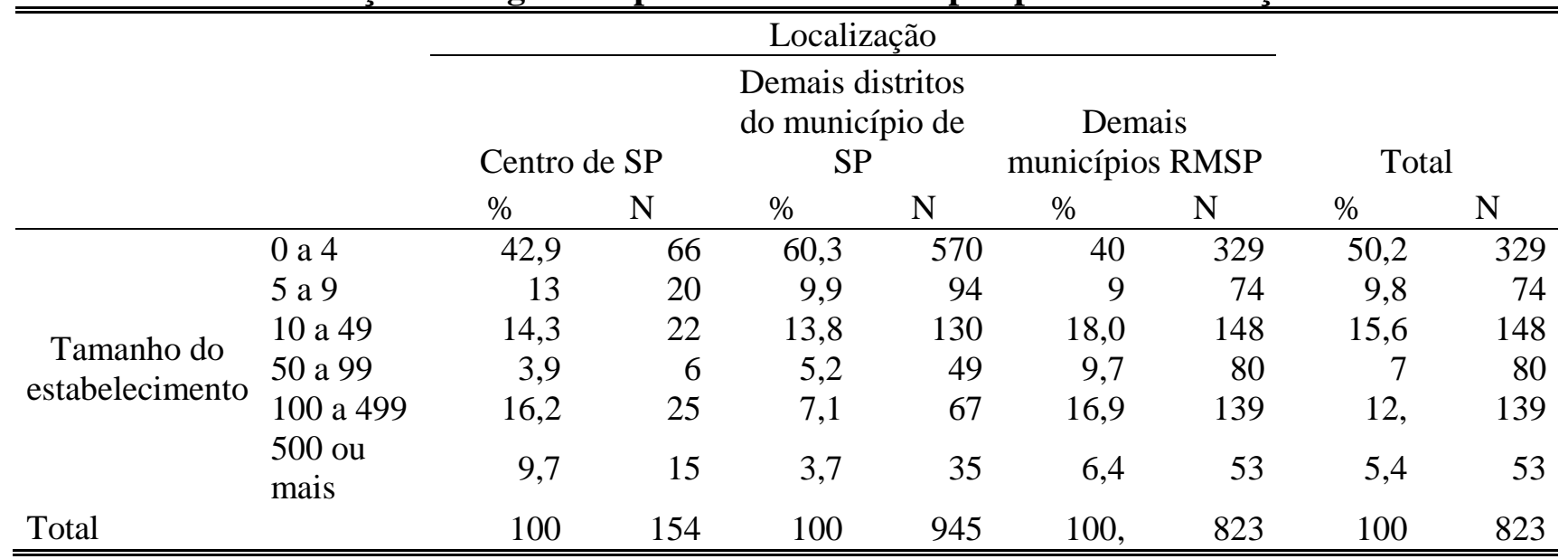

Fonte: MTE / RAIS2002 - Processamento equipe CEM

A característica mais importante do Centro como local privilegiado de pesquisa sobre a busca de trabalho em agência é a sua capacidade de atrair demandantes de toda a metrópole e até de fora dela, qualidade única desse espaço que não é observada em nenhum outro grande cluster de agências. A figura seguinte, usando os dados do survey "Á procura de trabalho", de 2004, apresenta a distribuição no espaço da metrópole paulista dos endereços de residência daqueles demandantes de emprego entrevistados no Centro ${ }^{23}$. Nota-se a enorme capacidade de atração de indivíduos dos mais diversos lugares que exerce o cluster de agencias do Centro; ao contrário dele, todos os demais clusters têm uma capacidade de atração apenas local. Ou seja, as pessoas que vão procurar emprego no cluster de Guarulhos são os moradores daquele município, salvo raras exceções; em Santo Amaro encontramos apenas moradores da zona sul da cidade de São Paulo; na Lapa temos os moradores próximos ás duas linhas de trem que passam por aquele bairro e assim para os demais. Diversidade e (muito provável) heterogeneidade dos demandantes de trabalho nos deram um forte argumento para escolher este como o espaço de referencia para observação e análise.

\footnotetext{
${ }^{23}$ Agradeço a Paulo Henrique da Silva pelo apoio no preparo destes dados.
} 


\section{Figura 1.2: Onde moram os demandantes entrevistados no cluster de agências do Centro}

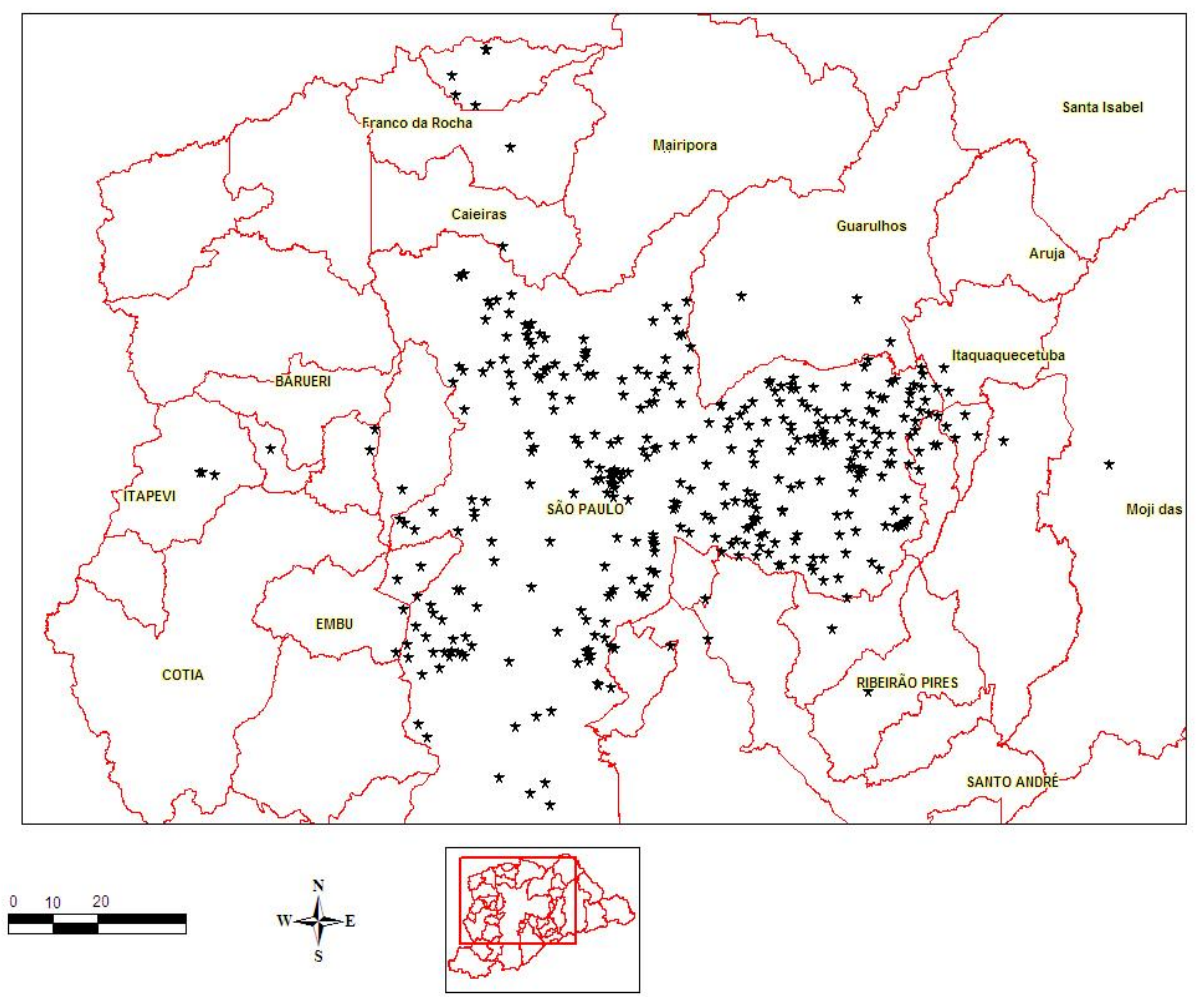

Fonte : Pesquisa direta CEM “À procura de trabalho”, região metropolitana de São Paulo, agosto de 2004

Porém, outras especificidades daquele cluster estimularam a sua escolha como local para sediarmos o trabalho empírico. Uma dessas interessantes características é que a maior parte dessas agências do Centro se concentra num espaço muito circunscrito, delimitado por alguns poucos quarteirões em torno do calçadão da Rua Barão de Itapetininga, o que cria uma configuração espacial interessante. Esse aglomerado de agências opera dentro de edifícios e galerias e não têm nenhuma visibilidade, o que gerou a necessidade de desenvolver alternativas de divulgação e captação de candidatos através da apropriação do espaço do calçadão e das ruas do entorno. Assim, naquele local o processo de procura se dá com o engajamento de tipos mais variados e peculiares de atores, dentre eles os plaqueiros que divulgam nas ruas as vagas de trabalho que as agências localizadas dentro de edifícios e galerias disponibilizam. A atuação desse tipo de ator configura formas diferenciadas de divulgação de vagas e captação de candidatos pelas agências, além de atípicas formas de apropriação do espaço das ruas por esse mercado e de interação com os demandantes.

Outra característica interessante é que ali, paralelamente ao mercado de intermediação, se concentra igualmente uma outra gama de serviços voltados ao publico em procura de trabalho tais 
como: manufatura e cópia de Cvs, comércio de listas com os endereços das agências de emprego da cidade, cursos de capacitação profissional, cursos para aprender a se portar em entrevistas de emprego e dinâmicas de grupo, empréstimos e adiantamento do seguro-desemprego, escritórios de advogados trabalhistas, entre outros. É impressionante o número de estabelecimentos que oferecem serviços correlatos à atividade da procura de trabalho. É interessante notar que uma boa parte desses serviços tem o objetivo de bem dotar os indivíduos à procura de trabalho, tornando-os bem apresentáveis e competitivos, tanto pelo lado da capacitação profissional quanto pelo lado da capacitação comportamental, frente aos olhos do intermediador de trabalho e/ou do futuro empregador (Hirano, 2007, Guimarães, 2007-b, Vieira, 2007).

A observação de um cluster de intermediação de mão-de-obra, como aquele que se localiza no Centro de São Paulo, sugere, assim, que a procura de trabalho, portanto, não é um empreendimento simples, como poderia parecer a princípio. As análises qualitativas das situações de procura deixam entrever o longo caminho que por vezes tem que ser percorrido para o desempenho da atividade da procura de trabalho e para qualificar-se como um bom demandante de emprego ou seja, alguém apto a concorrer por uma vaga no mercado de trabalho e merecer essa vaga. Não tem nada de trivial ou natural nesse processo, como em nenhum outro processo econômico e social. Não basta estar desempregado, ou à procura de trabalho, para "naturalmente" ser considerado habilitado a ocupar uma vaga. Há um processo de legitimação do indivíduo enquanto demandante de trabalho; o curso deste complexo processo se dá exatamente durante a procura de trabalho. (Guimarães, 2007-b; Tartuce, 2007, 2007-b). Há um conjunto de códigos e práticas que regem o desempenho da atividade de procura de trabalho, assim como uma série de relações sociais e interações que são estabelecidas ao longo dessa atividade e delas pode depender, inclusive, o sucesso e eficiência da procura.

Alem do mais, o Centro tem todo um atrativo em termos de sociabilidade urbana dada a enorme variedade de outros serviços, fracamente ou de todo desconectados da procura, mas de vivo interesse para os habitantes de uma grande cidade, notadamente para os jovens, que constituem a parcela mais importante de quem acorre aos serviços do mercado de intermediação, como se verá adiante. São parques, lojas, cinemas, monumentos, espaços de lazer, enfim, que são um atrativo especial; sem contar os bancos, órgãos públicos, serviços diversos que podem ser simultaneamente acessados no momento em que se procura trabalho.

Basicamente o que se pretende ressaltar aqui é que i) as observações dos clusters de intermediação apontaram que esses eram locais com potencialidade para revelar bastante sobre a 
prática da procura de trabalho e seus processos sociais constitutivos e ii) as primeiras observações no cluster da Barão de Itapetininga, no Centro de São Paulo, permitiram perceber que ali havia também uma diversidade e riqueza de instituições, relações e práticas que extrapolavam a simples relação agência-demandante, tornando aquela uma realidade micro-sociológica potencialmente densa e interessante para a realização de um estudo etnográfico sobre o processo de procura. Por isso mesmo essa última se mostrou uma escolha ainda mais interessante para essa investigação que se propunha, desde o início, a observar a procura de trabalho in loco, tal como vivida na prática pelos atores sociais.

Mas, quem são as firmas que acorrem a este espaço? Quem são estes intermediadores? Neste espaço de procura se concentram principalmente agências de pequeno porte (de resto, a significativa maioria em termos de numero de estabelecimentos, qualquer que seja o cluster); nelas circulam especialmente ofertas para vagas de trabalho pouco qualificados e mal remunerados, especialmente em Serviços, com destaque para as áreas de vendas e telemarketing. Isso naturalmente condiciona o perfil do demandante; assim, ainda que haja grande diversidade no que se refere ao local de moradia, o survey citado acima mostrou que o público que freqüenta o cluster do Centro de São Paulo se caracteriza por ser jovem (significativamente mais jovem que a média de outros clusters) e por possuir baixa qualificação e menor competitividade no mercado de trabalho (Guimarães, 2006-a, 2007-d; Tartuce, 2007, 2007-b).

Entretanto, nesse estudo de caso, a intenção não é a investigação profunda daquele mercado de intermediação de mão-de-obra, mas aproveitar a concentração de instituições, de serviços e de atores sociais ali envolvidos na procura de trabalho para explorar o próprio processo de procura com suas relações sociais, interações, práticas, códigos e significados sociais. Ou seja, utiliza-se o mais importante espaço metropolitano de busca de oportunidades ocupacionais para apreender mais sobre o processo de procura tal como vivido numa situação de procura peculiar. Para tal, observando uma situação de procura de trabalho específica e terrritorializada, pretende-se levar em conta espaço, atores, instituições e condutas sociais, assumindo que o processo de convergência entre uma vaga e um candidato, que se dá no bojo da ampla dinâmica do mercado de trabalho, não é natural e muito menos trivial. Procurar-se-á, para tal, evidenciar que nele operam práticas sociais e valores, e que a análise micro-sociológica é uma boa perspectiva de estudo para bem deslinda-lo. Acredita-se, retomando o argumento do capítulo, que seria pertinente tomar a procura de trabalho como um objeto de pesquisa e tratá-la como uma experiência social. Essa perspectiva da "experiência de procura" poderia ser bem desenvolvida através do recorte empírico das "situações de procura". E, 
para tanto, foi escolhido um caso de situação de procura territorializada, um importante espaço de procura da metrópole paulista.

Mas, antes de passar a apresentar resultados, e postas as balizas do contexto macro-social em que a análise se moverá, convém detalhar com maior cuidado a perspectiva teórico-metodológica que será aqui utilizada. Este será o objetivo do capítulo seguinte. Nele se buscará evidenciar os fundamentos teóricos em que estão ancoradas as noções chaves de "situação social" e de “experiência social”, norteadoras da perspectiva e do recorte aqui propostos e que pautam, por conseqüência, tanto a construção do trabalho de campo quanto a análise dos dados nele coletados.

Assim, no próximo capítulo tentamos novamente argumentar, agora pelo diálogo com literatura e com a produção acadêmica (e não, como no item que aqui se finda, pelo dialogo com os dados do macro-contexto), a pertinência de tornar a procura de trabalho um objeto si, de encará-la como uma experiência social e de abordá-la através da análise das situações de procura, tomando uma situação de procura como caso de estudo.

Ademais, o próximo capítulo se encarregará também de dar ao leitor todas as informações necessárias a entender como se passou de um enfoque teórico a um desenho empírico, deixando claros os passos adotados na construção do problema de pesquisa, não apenas por apresentar as bases teórico-metodológicas dessa investigação, mas também por descrever detalhadamente os procedimentos e processos transcorridos no trabalho de campo. 


\section{CAPÍTULO 2}

\section{Um interlúdio teórico-metodológico: os fundamentos da construção do objeto}

Como procuramos argumentar até aqui, é de suma importância tomar a procura de trabalho como um objeto sociológico em si. Estudos qualitativos sobre essa questão podem ser muito fecundos. Mas, existem variadas formas de se empreender um estudo qualitativo sobre a procura de trabalho. Aqui, será analisada uma situação de procura de trabalho específica e espacialmente delimitada. Para tal, parte-se do suposto de que uma situação social é revestida de lógica e sentidos próprios e pode ser tomada como unidade analítica e como parte da experiência social, a qual é composta por um repertório múltiplo de situações sociais. Assim, uma situação social de procura de trabalho comporia, juntamente com outras situações desse tipo, a experiência social da procura de trabalho.

O local apresentado no capítulo anterior, o qual foi escolhido como recorte empírico dessa pesquisa é tomado então como uma situação de procura de trabalho, que é também uma unidade de análise, entre outras possíveis, para recomposição de parte da experiência da procura de trabalho, tal como vivida pelos demandantes.

Esse recorte analítico está baseado numa série de noções e conceitos sociológicos que formam a base teórico-metodológica do presente estudo qualitativo, pautado em um olhar interpretativo que convém apresentar, pois ele condiciona não só a interpretação dos dados como a própria construção dos processos de coleta de informações. Assim, o que se pretende nesse capítulo é explicitar a forma como foi construída a pesquisa. Primeiro apresentaremos as noções e conceitos que serviram como inspiração teórica e orientação da construção do trabalho de campo, explicitando a definição de situação social e dos elementos que a compõem. Em seguida, detalharemos os processos e procedimentos práticos adotados no trabalho de campo, recompondo o processo de pesquisa empírica que tomou a situação de procura como unidade de análise e tentou captar os seus elementos constituintes.

\section{A construção teórico-metodológica da situação de procura. A experiência social e as situações sociais como unidades de análise}

A definição de situação social é especialmente importante para esse trabalho, pois nela está baseado o recorte empírico da situação social de procura de trabalho, que é a unidade analítica deste 
investigação. A relação entre a experiência social da procura de trabalho e a situação de procura é uma dimensão que guia essa pesquisa. Os elementos que constituem uma situação social também dever explicitados, pois tanto o trabalho de campo quanto a análise buscaram recobri-los e captá-los.

Essa discussão está baseada nas elaborações de um conjunto de autores ligados ao que usualmente reconhecemos com o nome de interacionismo simbólico. ${ }^{24}$ Buscando encarar os limites da perspectiva voluntarista do utilitarismo e da perspectiva determinista do funcionalismo, o interacionismo se propôs a estudar a experiência social da ação através das "situações sociais". Nelas, a ação não adota a forma de mera transferência de regras fixas; ao contrário, esses autores partem do princípio de que as definições das relações sociais são recíproca e conjuntamente estabelecidas (Joas, 1999). Questões como interação entre agentes, desempenho de papéis sociais, condutas sociais e interpretação dos símbolos e sentidos da ação são centrais a sua agenda. Por isso mesmo, o interacionismo tem uma constante preocupação com a construção cotidiana da realidade social e com o universo empírico, assumindo assim os dilemas e desafios metodológicos da pesquisa de base qualitativa. Utilizam-se aqui conceitos e noções desenvolvidos por alguns dos autores comumente associados a essa tradição, sem ignorar as diferenças entre eles e, por isso, mesmo fazendo um uso seletivo das elaborações teóricas de cada um deles que parecem contribuir mais para o desenvolvimento dessa pesquisa. George Mead, Herbert Blumer, Anselm Strauss e Erving Goffman são, dentre eles, os autores que tomaremos como principais para melhor circunscrever o conceito chave de "situação social".

\footnotetext{
${ }^{24}$ Há muita discussão sobre a pertinência de se encarar o interacionismo como uma tradição sociológica una, dada a diversidade entre os autores classificados como interacionistas, cujas idéias, bem sabemos, estão longe de apresentarem uma perfeita coesão em torno de um mesmo arcabouço teórico-metodológico. Com efeito, alguns dos autores que adiante referiremos são, por vezes, associados a linhagens nomeadas de modos distintos, às vezes como "dramaturgia", outras tantas como "etnometodologia". Sem embargo, e tal como exploraremos adiante, proximidades não desprezíveis em seus pontos de partida, tanto quanto no modo de encarar a realidade empírica e o conhecimento sobre ela formulado, autorizaram outros intérpretes a privilegiar as convergências em detrimento das notórias diferenças entre eles existentes. Se mais não fosse porque diversidades de pensamento jamais impediram que reconhecêssemos convergências, como as que nos permitem nomear e alinhar autores ao redor de paradigmas como o "funcionalismo" ou o "marxismo", apenas para citarmos dois exemplos. Nessa linha de entendimento, se tomarmos um pensador da teoria sociológica como J. Alexander, veremos que, para ele, é indiscutível que se possa reconhecer no interacionismo simbólico uma linhagem do pensamento da ciência social. Sua narrativa a este respeito é um exemplo de entendimento que valoriza as aproximações frente aos elementos que distinguem esses autores. Assim, para ele, essa abordagem teórica tem uma origem temporal e espacialmente demarcável: desenvolveu-se no início do século XX nos Estados Unidos, mais precisamente, ao redor da influencia do Departamento de Sociologia e Antropologia da Universidade de Chicago. Tem nomes de estirpe,como Charles Cooley, Willian Thomas, George Mead; e, posteriormente, Herbert Blumer, Ernest Burgess, Louis Wirth e Everett Hughes. Forjou uma agenda de pesquisa empírica própria, rica e diversa, com ênfase nos problemas sociais urbanos da época como migração, violência e segregação racial. Assim, por volta da década de 1950, período a partir do qual sua visibilidade internacional se torna crescente, o interacionismo destacou-se tanto nos Estados Unidos quanto em outros países, tendo pouco a pouco adquirido proeminência internacional, marcadamente por sua critica contundente ao estrutural-funcionalismo, perspectiva teórica então dominante (Alexander, 1987).
} 
Começando com Goffman, assumimos aqui que as situações sociais são momentos privilegiados para a análise sociológica, isto é, para a análise do modo como se constroem as experiências sociais. Goffman explora a pluralidade de mundos sociais em que os indivíduos têm que atuar; imprescindíveis para compreender, através da ação, o engajamento dos indivíduos na sociedade e sua vivência da experiência social. Ele diz de forma bastante simples em Manicômios, Prisões e Conventos (2003) que "uma disposição básica da sociedade moderna é que o indivíduo tende a dormir, brincar e trabalhar em diferentes lugares, com diferentes co-participantes, sob diferentes autoridades e sem um plano racional geral" (Goffman, 2003, pp17). Assim, a experiência social se organizaria segundo um conjunto variado de situações, dotadas de linguagens e códigos próprios. O autor resume a sua teoria das situações ou momentos comuns numa frase provocativa: "Not, then, men and their moments. Rather moments and their men" (Goffman, 1982, pp. 3) ${ }^{25}$. As situações são, para Goffman, uma unidade de análise, já que revestidas de características próprias. É preciso entender uma situação tendo em conta a "membrana" que a envolve tornando-a uma realidade social específica; mas, e ao mesmo tempo, há que entender o contato dessa membrana com o exterior, captando como ela faz parte de uma realidade social mais ampla ${ }^{26}$.

"I have argued in this paper that any social encounter, any focused gathering, is to be understood, in the first instance, in terms of the functioning of the 'membrane' that encloses it, cutting it off from a field of properties that cold be given weight." (Goffman, 1961, pp. 80, grifos meus)

Outra questão fundamental é a relação entre uma situação e uma conduta social que é, para Goffman, intrínseca e pode ser apreendida na sua definição conceitual abaixo. Nela, vê-se que a situação estrutura a conduta e vice-versa; essa relação de estruturação se dá através de códigos culturais, da manipulação desses códigos e da interpretação da situação por parte dos agentes:

"I can be argued that social situations, at least, in our society, constitute a reality sui generis as He used to say, and therefore need and warrant analysis in their own right. (...) I would define a social situation as an environment of mutual monitoring possibilities, anywhere within which and individual will find himself accessible to the naked senses of all others who are present, and similarly find them accessible to him. (...)

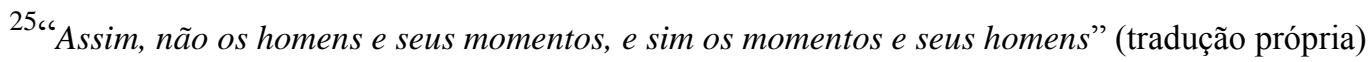

${ }^{26}$ Ou seja, as situações sociais são unidades de análise-chave para entender a complexa e imprecisa articulação entre a ordem macro-estrutural e a ordem micro das interações. Ela é importante também, pois ajudaria a responder a pergunta básica que perpassa toda obra de Goffman que é: como a sociedade se infiltra na vivência cotidiana dos indivíduos? Longe de desprezar as estruturas sociais em suas análises, crítica que lhe foi dirigida com frequiência, o que Goffman busca é, antes, o efeito que estas exercem sobre a experiência social cotidiana dos indivíduos, através de suas condutas e interações ordinárias, ou seja, como as estruturas de diferenciação (econômica, política, racial, entre outras) se expressam na vivência das experiências as mais rotineiras, como na vivência das situações sociais diversas.
} 
Cultural rules establish how individual are to conduct themselves by virtue of being in a gathering and these rules for commingling when adhered to, socially organize the behavior in the situation. Although participation in a gathering always entails constraint and organization, there are special social arrangements of all or some of those present which entail additional and greater structuring of conduct." (Goffman, 1964, pp. 134-135, grifos meus)

Já a noção de "mundo social" cumpre, no pensamento de Strauss, papel equivalente ao de "situação social" presente nas formulações de Goffman. Na esteira de sua influência interacionista, de inspiração meadiana, Strauss (1999) cunha o termo "mundos sociais", categoria desenvolvida para a investigação de sociedades complexas, como a contemporânea, em que os indivíduos atuam em diversas esferas, independentes entre si. Cada um desses mundos pode ter dimensões cognitivas e comunicacionais - e, portanto, simbólicas - muito particulares. Desse modo, a ação só pode ser analisada levando em conta a especificidade de cada mundo social; ou seja, para ele a ação também precisa ser situada e a relação de dependência entre situação e condutas também é fundamental.

Strauss (1999) demonstra especial interesse pelos mundos sociais em que as afiliações dos atores são sutis, frouxas e pouco institucionalizadas: atraem-no os agrupamentos abstratos, cuja existência não é tão aparente no que se refere a interesses comuns ou estruturas definidas, mas que são determinantes da vida social dos indivíduos. Por mais estranha que possa parecer a idéia de "afiliação a grupos abstratos", com ela Strauss pretende chamar a atenção para o fato de esse tipo de afiliação é especialmente importante para a vivência social, dotando-a de um conjunto de símbolos e valores, mesmo que pouco formalizados ou explícitos. Isso é, a nosso ver, exatamente o que ocorre na situação de procura estudada. Isso porque, se as interações acontecem entre os indivíduos, esses também representam, em termos sociológicos, diferentes coletividades que se estão expressando por meio das interações nas diversas situações ou mundos sociais. Assim, estrutura social e interação estão intimamente relacionadas na geração e manutenção dos comportamentos coletivamente construídos e partilhados nos mundos sociais diversos.

Strauss considera, portanto, imprescindível que as teorias tentem captar as relações entre homens e estruturas, mas que o façam sem se perder em abstrações teóricas, pois a Sociologia, a Antropologia e a Psicologia social deveriam se voltar para a "vida real" a fim de tentar explicá-la. A análise de situações sociais seria um caminho para realizar tal empreendimento sociológico:

“... uma teoria da ação não deveria ser abstrata ou especulativa ao ponto de nos impedir de atingir a compreensão dos aspectos mais concretos da 'verdadeira vida' ou da 'vida em geral'. Lendo certas teorias da ação, é fácil perder-se em suas abstrações e seus densos comentários orientados para questões criadas por outros teóricos. De tal maneira que, após ter lido esses textos, é preciso dar um salto imaginativo para mergulhar de novo nos acontecimentos, nas situações, nos problemas, nas paixões e nas 
lutas das pessoas reais, de suas instituições e outros coletivos." (Strauss, Continual Permutations of action, apud: Lahire, 2002, pp. 16)

É de extrema importância para a delimitação do nosso próprio objeto do estudo aqui apresentado a idéia, desenvolvida tanto por Goffman quanto por Strauss, de que "situação social" ou "mundo social" são, em primeira instância, unidades de análise e devem ser entendidas como tal, em sua dinâmica interna e tendo em conta sua membrana de contato com o exterior. Além disso, partese do princípio que a conduta social de uma pessoa à procura de trabalho é construída dentro da situação de procura, portanto é uma conduta situada. Esses pontos de partida teóricos que fundamentam a noção de situação afetam a definição do nosso objeto, inspirando-nos a estruturar duas dimensões chaves a observar, a saber: (i) o modo pelo qual está constituída internamente a situação de procura de trabalho, vale dizer, a sua dinâmica interna; (ii) o modo pelo qual as estruturas sociais e outras dimensões da realidade social estão refletidas na constituição dessa situação de procura de trabalho, vale dizer, as "membranas" de contato daquela situação social $\underline{\text { com }}$ o exterior.

Para esses autores as situações sociais, em suas dinâmicas internas, são constituídas basicamente por três elementos e seus sub-processos: espaço, interações entre os atores e condutas sociais. Esses três elementos são reciprocamente condicionados e articulados e a cada articulação específica entre eles corresponde uma realidade social peculiar, ou seja, uma situação social. A análise da situação de procura de trabalho estudada foi pautada nesses elementos e a pesquisa de campo foi construída de forma a tentar captá-los. Vejamos a seguir e de modo mais sistemático, como tais elementos são teoricamente problematizados pelos autores mobilizados na construção da base teórico-metodológica dessa pesquisa.

\subsection{O espaço no delineamento da situação social: dimensões e processos espaciais}

Um dos principais elementos constituintes de um "mundo social", diz Strauss, é sua relação com o espaço (Strauss, 1979). Aspectos físicos do espaço produzem efeitos na operação dos mundos ou situações sociais, na interação entre os atores e na construção de condutas sociais. Os dispositivos físicos que podem ou não ser mobilizados pelos atores no curso da interação podem levar os atores a criar estratégias especificas para interagir naquele espaço e/ou para dele se apropriar no curso da dinâmica da situação social.

As formas de utilização e apropriação dos espaços pelos atores em interação dependem de algumas características desse mesmo espaço, tais como apresentadas por Strauss (1979, pp. 1-2): 
1-Escopo de dispersão espacial: as atividades estão concentradas ou dispersas?

2-Quantidade de espaço utilizado nas atividades: há muito ou pouco espaço?

3-Número de espaços e sub-espaços utilizados na situação social

4-Compartilhamento de espaços com outras situações sociais

5-Visibilidade dos espaços para atores externos à situação social: há visibilidade completa ou ela é inexistente?

6-Acessibilidade dos espaços para atores externos à situação: ela é muito fechada ou muito aberta?

7-Grau de organização do espaço: se trata de um espaço muito diferenciado e organizado ou relativamente indiferenciado?

8-Frequiência da utilização do espaço pelos atores

9-Hierarquia entre espaços

Essas dimensões caracterizam fisicamente o espaço, condicionam as interações que nele se estabelecem e configuram a dinâmica da situação social e, por isso, são dimensões que articulam espaço e situação social. A nossa análise da situação de procura de trabalho investigada foi feita também a partir dessas dimensões espaciais que a observação permitiu captar.

Mas, além das dimensões que influenciam a apropriação do espaço para o desenvolvimento da atividade central da situação social (tal como a procura de trabalho para o caso da situação social de procura), Strauss diz que existem alguns processos que se desenvolvem nas situações que são, essencialmente, processos espaciais. Nesses processos, o uso do espaço não seria secundário à realização de alguma atividade, mas estaria no foco da realização de algum objetivo. A busca ou abandono de locais para o desempenho de determinadas atividades por grupos, por exemplo, é um desses processos espaciais. Assim são também os processos de reconfiguração ou de competição por espaço, e os processos que tentam tornar determinados espaços, mobilizados em situações sociais, mais visíveis e acessíveis, ou, ao contrario, invisíveis e inacessíveis. Assim, Strauss chama atenção para existência de outros processos, além dos processos de interação, nas situações sociais. Os processos espaciais, em conjunção com os outros processos que constituem uma situação social, são responsáveis por sua manutenção ou transformação e, embora a importância desses processos seja verdadeira para todas as situações sociais, Strauss reforça que é preciso entender quais deles são mais relevantes para a configuração de cada situação social específica. Como se verá este aspecto também comporá a análise do espaço de procura, tal como será apresentada adiante, no capítulo 3. 
O espaço, com suas configurações físicas e arquitetônicas pode estabelecer (ou não) os limites físicos em que transcorre uma situação social; mas, e principalmente, pode constranger a atuação daqueles que dela participam. O espaço não é meramente ilustrativo nessa abordagem, mas, pelo contrário é constitutivo da situação social. A relação entre atores e espaço pode especificar e diferenciar muito uma situação social frente a outras. Construir uma cartografia da situação de procura de trabalho aqui investigada, tendo em vista as dimensões e os processos espaciais acima listados, será, então, condição primeira para explorar seus limites, agentes e dinâmica.

\subsection{Os atores em interação: a construção interativa e negociada da situação social}

Apesar de todas as diferenças entre as abordagens teóricas dos autores rotulados como interacionistas, há um pressuposto que os aproxima: as situações sociais são baseadas nas interações entre os atores. A ação numa situação é, desde Mead, em primeiro lugar, relacional, ou seja, fruto de interação. A interação é a relação que um ator estabelece com outro quando em co-presença, ou seja, quando um está na presença visível do outro; essa é uma idéia que perpassa as abordagens de Mead, Blumer, Goffman e Strauss. Essa interação pode ser verbal, mas também corporal e gestual; mesmo uma simples expressão facial é evidência de interação. Quando um ator está em presença do outro, até mesmo o silêncio representa um modo de interação.

Essa interação é determinada, primeiramente, pelo espaço em que ela se desenvolve e por seus dispositivos físicos, como enfatizado no item anterior, mas também pelos atores que nela estão envolvidos. Portanto, é fundamental entender o que cada ator representa na situação social em questão e, por conseqüência, o que representa na interação com os outros atores. É importante entender o papel ou lugar social a partir do qual aquele ator interage com os demais. Assim, quando um ator interage com outro na qualidade de parte, membro ou funcionário de uma instituição ou grupo social, é fundamental entender as características dessa instituição ou grupo, assim como os códigos e regras que os regem, tal como se buscou fazer nos capítulos empíricos, com os atores e instituições envolvidos na situação de procura estudada. Entender as características e o funcionamento das instituições que estão envolvidas na situação de procura é fundamental para compreender a dinâmica das interações que seus membros, no caso, seus funcionários, estabelecem com os demais atores da situação e como eles representam e negociam tal identidade institucional na dinâmica da situação de interação.

Ao aprofundar os princípios práticos desse tipo de relação, Mead (1952) ressaltou que a interação se dá quando há um comportamento cooperativo; esse, por sua vez, só é possível quando 
cada ator percebe a intenção dos atos dos outros com os quais interage, e constrói sua própria resposta tendo como referência sua interpretação daquela intenção. Vale dizer, na interação social, é necessário que cada ator possa entender as linhas de ação dos outros e possa direcionar seu próprio comportamento de forma a se acomodar àquela linha de ação. Para Mead, a ação se funda nos sentidos compartilhados sob a forma de interpretações e expectativas comuns construídas no ato da interação e expressas pela linguagem, inclusive gestual. Por isso mesmo, buscou-se na análise da situação de procura de trabalho, através de observações sistemáticas e entrevistas, descobrir quais eram as expectativas que um ator tinham em relação a outro, assim como os sentidos compartilhados por eles que embasavam as suas interações.

Para Strauss (1988), além dos processos comunicacionais, as negociações são o substrato das interações e dependem dos tipos de atores, das estratégias utilizadas por eles e do que está em jogo no processo de negociação. É certo que o termo "negociação" pode ser associado a um amplo corpo de literatura e é ele mesmo um termo muito amplo, largamente utilizado pelo interacionismo simbólico e pela teoria da troca (embora em sentidos diferentes). Porém, Strauss argumenta, não havia sido usado ainda como conceito, como um objeto em si ou como instrumento para pensar a ordem social, no que residiria a inovação de sua proposta. Essa noção enriqueceu a idéia de "situação social" (que em sua teoria aparece como "mundo social") com a busca clara de articulação com elementos tais como hierarquia e autoridade, interligando, assim, diversos níveis de análise. Strauss parte do princípio de que toda e qualquer ordem social, micro ou macro, é assentada, em alguma medida, em relações de negociação. As negociações seriam processos presentes em ordens

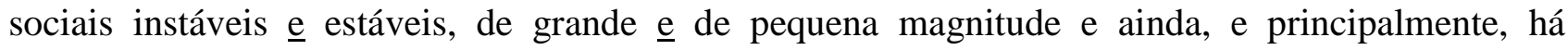
negociações entre ordens sociais de natureza distintas, como entre ordens macro e micro sociais. $\mathrm{O}$ paradigma das negociações seria uma ferramenta analítica para compreender não apenas a articulação de interações numa situação ou mundo social, mas também para produzir conhecimento sobre a interdependência das situações sociais com as estruturas. Aqui as ações são situadas e a ordem social é negociada, pois se trata de uma "ordem negociada".

\footnotetext{
"The implication is that social orders are, in some sense, always negotiated orders. The phrase "in some sense' is a guard against asserting that negotiation explains 'everything' for it is always found in conjunction with others processes, other alternatives to getting things done - notably coercion, persuasion, manipulation, and the like. (...) I have argued that issues of outcome, efficiency, decision making and the like are secondary to issues pertaining first to how negotiation is related to other modes of action and second to varying kinds of social order. I have also argued that larger structural considerations need to be explicitly linked with microscopic analyses of negotiations processes. Negotiations always take place within social setting. The various structural conditions of the settings affect the actions of the negotiating parties, the aims they pursue though negotiation and alternative modes of action, their tactics during the
} 
negotiations, and, undoubtedly, the outcomes of the negotiations themselves - which in turn may affect not only future courses of action but also the social setting themselves." (Strauss, 1988, pp. 335)

Importa nessa abordagem das interações o contexto da negociação. Cada um desses contextos, seguindo Strauss seriam unidades que delineiam uma configuração particular de negociação, definindo o que é negociado, por quem, de que maneira, com qual propósito e com quais conseqüências. Cada contexto de negociação é, de alguma forma, conectado a outros contextos , os quais são interconectados entre si e podem formar uma escala organizacional mais ampla e complexa. O contexto de negociação e seus sub-processos formam o que o autor chama de "contexto estrutural", um conjunto de propriedades estruturais que são diretamente relacionados às negociações que se dão no curso das interações analisadas pelo pesquisador. Na situação de procura várias coisas podem ser negociadas pelos atores. Buscou-se captar o que era negociado, por quem e com quais objetivos. Para captar também os contextos em que se realizaram essas negociações, tentou-se investigar a relação delas com outras dimensões da vida social, em tese exteriores à constituição daquela situação de procura.

Se em Strauss a ordem é negociada, em Goffman ela é interativa; para este último a “interactional order" seria um domínio legítimo da Sociologia e uma unidade de análise possível para a micro-sociologia (Goffman, 1983,1983-b, 1963). Mas, Goffman dá ênfase à idéia de que a vida social pode ser comparada metaforicamente a um jogo de informações. É importante, portanto, nesse ponto de vista, observar os processos de manipulação das informações pelos atores em interação, pois, diz Goffman, os indivíduos querem influenciar a definição da situação, para assim poder construir sua representação. Esses processos de manipulação de informações se mostraram fundamentais à manutenção das interações na situação de procura de trabalho.

Seguindo a herança de Mead, a interação na situação, para Goffman (1983, 1988), é, além de um jogo de informações, também uma "atividade cooperativa" e baseada em um "consenso operacional". É uma atividade cooperativa porque cada indivíduo em interação fornece e/ ou esconde informações sobre si e, ao mesmo tempo, tem que aceitar as informações que os outros lhe fornecem. Cada um constrói seu personagem em função do personagem que o outro vai desempenhar e, assim, cada um tem que aceitar o personagem do outro para desempenhar o seu. $\mathrm{O}$ consenso operacional de que fala Goffman está baseado na tendência de que os atores, em conjunto, contribuam para uma definição da situação a fim de evitar rupturas ou conflitos na interação (Goffman, 1983, pp.18). Para que uma performance numa situação social seja boa e convincente, é necessário que o ator saiba o que esperar daquele com quem interage e saiba o que esperam dele. 
Tudo isso, pois, na ordem interativa de Goffman, há sempre algum espaço para manipulação consciente das regras no curso da interação; apesar da aceitação tácita do "léxico" social e da existência de padrões de comportamento institucionalizados, pois:

“... quando as pessoas se engajam em relações controladas por regras, empregam rotinas ou práticas sociais, adaptações padronizadas - incluindo ajustes, desvios, variações secretas, infrações desculpáveis. Esses padrões do comportamento real (...) associados com regras básicas, constituem juntos o que pode ser chamado 'ordem social”' (Relations in Public places, apud Nunes, 2005, pp. 101, 102).

Ao lado de entender as técnicas de negociação e de manipulação de informação, tentou-se apreender também como os atores na situação de procura colocam em prática as técnicas de adequação da performance às expectativas do ator com quem interagem, de modo a manter o consenso operacional e a ordem da situação.

Assim, com base nessas noções, as interações entre os atores envolvidos na situação de procura serão analisadas adiante, levando em conta: i) o espaço físico no qual elas transcorrem, ii)as características de cada tipo de ator e o papel social que desempenha naquela situação (nisso compreendidas as características da instituição social da qual eles eventualmente fazem parte, como é o caso dos funcionários das agências de emprego e dos demais estabelecimentos comerciais que ali operam) e iii) a própria natureza da interação entre os atores, caracterizando-a em suas técnicas corporais e discursivas e em seus significados sociais.

\subsection{Condutas sociais: situadas, interativas e padronizadas}

Para os autores mobilizados nessa análise, as condutas sociais são conjuntos de práticas desenvolvidos por diferentes tipos de atores em diferentes situações sociais. Assim, as condutas sociais são situadas, segundo Mead, Strauss e Goffman, e construídas pelos diferentes atores no curso da interação, como disse Blumer (1969). Diferentes conjuntos de práticas são esperados de diferentes atores em situações específicas. Ou seja, há uma expectativa social de que certos personagens, em determinadas situações, desempenhem condutas sociais específicas. Essas são constituídas por conjuntos de práticas peculiares, que englobam ações, gestos, discursos, componentes visuais e estéticos. Está implícita na idéia de conduta uma padronização de comportamentos que responde às expectativas sociais, baseadas em representações sociais, referentes ao papel desempenhado e à situação na qual ela transcorre. Porém, para esses autores, essa padronização coexiste com a re-interpretação dos códigos de conduta por parte dos atores durante a interação. Nisso radica a riqueza dessa abordagem e a complexidade da pesquisa empírica por ela norteada. 
Assim, há uma noção proposta por Mead que se tornou fundamental nesse debate e também para essa pesquisa, que é a noção de "atitudes sociais generalizadas"27. As atitudes sociais generalizadas são séries de comportamentos institucionalizados, os quais representam respostas padronizadas e práticas comuns em situações particulares (Mead, 1952, pp. 262, 263). Cada situação pode ter um conjunto de atitudes sociais generalizadas típicas, as quais se esperam dos atores e às quais os atores tendem a desempenhar. Fica claro que, ao tratar disso, ele chega à noção de "condutas sociais".

Mas, se Mead ressalta as formas organizadas e padronizadas de ação que variam de acordo com as situações, ele também explora também a capacidade humana de criação de formas alternativas de ação e de variações. Estas, entretanto, se encaixam em um conjunto de reações esperadas para cada situação, pois há sempre um espaço para re-interepretação e re-elaboração das regras sociais. Para essa pesquisa foi fundamental reter das idéias de Mead a noção de "atitudes sociais generalizadas". Assim, é possível observar essa padronização de comportamentos e respostas na situação de procura de trabalho, o que será desenvolvido no curso dos capítulos empíricos. Essa foi uma questão especialmente investigada para um tipo de ator da situação estudada, o demandante de trabalho. Mas, igualmente relevante, como se verá adiante, foi reter a sua idéia de que existiria uma dimensão criativa e flexível da construção das condutas sociais, tanto quanto seguir as pistas da sua proposta de análise das interações sociais através dos gestos e da comunicação.

Com efeito, na abordagem de Strauss, assim como na de Mead, a linguagem assume papel fundamental na análise das condutas sociais e, consequentemente, na análise dos "mundos sociais". Através de nomeações, classificações e linguagens compartilhadas pelos grupos é que se dá o constante processo de formação de coletividades e identidades, que se expressam em condutas.

Goffman, ao tomar a situação como unidade, não trata do indivíduo ou personagem, mas da figuração e da performance, pois a reputação social não se aloja no interior nem na superfície do indivíduo, mas no curso da interação. Ao tratar de performance e reputação, Goffman também trata das condutas sociais. Na construção da performance para Goffman entram igualmente os gestos e os modos de agir. Na procura de trabalho os gestos e os modos de agir, ou seja, a própria figuração e performance, são determinantes do resultado do processo. De fato, e como veremos adiante, não basta procurar, o demandante precisa convencer os outros atores envolvidos na procura de que é um bom candidato; essa questão será tratada em detalhe.

\footnotetext{
${ }^{27}$ Para mais detalhes sobre esse conceito e a discussão gerada por ele ver: Alexander,1987; Becker \& McCall, 1990; Collins, 1994; Haguette, 1987 e Mead, 1952.
} 
A tentativa de tratar das condutas sociais fica ainda mais explícita no conceito de "representações coletivas" de Goffman, a partir do qual o autor trata de padrões de ação e atuação. Apesar da possibilidade de criar e manipular informações, os indivíduos situados em determinados grupos têm às vezes, Goffman diz, permissão ou obrigação a manter uma mesma "fachada social", ou seja, um mesmo tipo de comportamento. São as condutas socialmente institucionalizadas, em torno das quais há estereótipos ou conjuntos de expectativas estáveis. Aos papéis sociais correspondem determinadas representações coletivas ou idealizadas e a cada representação corresponde um conjunto de práticas sociais. Isso também como ocorre na situação investigada; a representação do "bom candidato", que é construída a partir de um conjunto de práticas, é um dos exemplos de conduta social que se tentou compreender. As práticas sociais seguiriam padrões de ação pré-estabelecidos para tipos de papel social ou para situações sociais específicas; essas tendem a ser reproduzidas com alguma uniformidade e freqüência, funcionando como uma espécie de "atalho" no constante processo de construção de performances sociais. Para que essas representações idealizadas sejam adequadamente desempenhadas, é, muitas vezes, preciso que os indivíduos abandonem ou escondam ações e emoções que sejam incompatíveis com as condutas que devem ser desempenhadas. Assim, apenas mediante conhecimento dos códigos da conduta e da disciplina social é que se pode representar um personagem por um período longo de tempo, nos termos de Goffman.

Inspirando-nos nessas noções, tentamos captar, ao longo da pesquisa de campo, as condutas sociais de cada um dos tipos de atores envolvidos na situação de procura de trabalho estudada, a partir do conjunto de práticas, ações, gestos e códigos que lhes são característicos, conferindo maior destaque para as condutas sociais dos demandantes de trabalho. Isso, levando em conta que: i) as condutas sociais são interativas e situadas, respondendo à dinâmica interna daquela situação, ii) mas são também padronizadas, respondendo às expectativas pautadas em representações sociais referentes àquela situação e àquele papel social e que iii) tais representações sociais, no entanto, extrapolam os limites daquela situação social específica, pois são construídas e disseminadas em outras dimensões sociais.

$\mathrm{Na}$ configuração da situação de procura estudada foram tomados em conta os seguintes elementos:

i) o espaço (encarnado de usos e apropriações sociais),

ii) os atores (com suas características e interações entre si e com o espaço) e 
iii) as condutas sociais (desempenhadas pelos atores e condicionadas pelo espaço - e pelos usos que dele se faz -, pela interação com os demais atores e pautadas por representações sociais)

De acordo com a argumentação acima, é impossível pensar:

i) Espaço sem atores ou sem apropriações e práticas sociais específicas

ii) Atores sem espaço para situar suas condutas sociais ou atores sem condutas sociais situadas

iii) Condutas sociais desenraizadas dos espaços em que são encenadas ou condutas sociais desencarnadas de seus atores e das interações em que eles estão imersos

Desse modo, através do estudo de uma situação concreta de procura de trabalho, busca-se entender um pouco mais sobre a vivência cotidiana da procura, tal como ela é construída in loco e ao longo da própria atividade de procura, o que possibilita desvendar as relações, processos e códigos que ali tomam lugar. Ou seja, trabalhamos com uma noção de "vivência situada" tentando apreender, em primeiro lugar a própria situação, sem, contudo, desconsiderar que ela é parte de uma vivência social e subjetiva mais ampla, a saber, a experiência da procura de trabalho. Parte-se do pressuposto de que uma investigação sobre a "vivência situada" da procura de trabalho poderia captar, com mais facilidade e espontaneidade, discursos dos demandantes sobre os elementos sociais e subjetivos que estão envolvidos nessa atividade. Com isso, poder-se-ia entender, a partir de uma situação de procura específica, parte da experiência social da procura de trabalho, composta por um repertório de diversas situações sociais.

\section{A construção do trabalho de campo na situação de procura: processo e procedimentos}

A construção da etnografia, a escolha dos procedimentos metodológicos e as decisões mais práticas e operacionais do trabalho de campo tiveram como base as orientações teóricometodológicas depreendidas dos autores antes apresentados. Descrever o processo de realização do trabalho de campo e de construção da etnografia será, então, o próximo passo. Problematizar-se-á, a seguir, tanto o que foi realizado, em quais situações e a partir de quais procedimentos, como o que não foi possível realizar e por quais razões. Assim fazendo, podemos explicitar como essas noções e conceitos foram mobilizados seja nas decisões metodológicas, seja no processo de construção da análise que será apresentada nos capítulos seguintes.

Fiel à inspiração interacionista, a pesquisa teve a intenção de se aproximar ao máximo do "mundo empírico", captando a vivência prática e cotidiana da procura de trabalho, através de uma situação social de procura e recobrindo os vários elementos que a compõem, a saber: espaço, 
instituições, atores, condutas, práticas e discursos. Tenta-se realizar esse empreendimento através da proposta metodológica da proposta de ir ao "mundo empírico", nos termos de Blumer, e com a disposição distinta de um "outsider", buscar a análise da ação através da observação da "vida real", tal como defende Strauss, ou do "cotidiano", como na terminologia de Goffman. Justamente por isso a observação participante foi escolhida como estratégia metodológica de inserção naquela situação e de coleta de informações e discursos. Para captar a construção da situação social e todos os fatores que a determinam optou-se, a princípio, pela observação participante ${ }^{28}$ Tal escolha estava em consonância com o desejo de não apenas observar de perto, mas de "perto e de dentro" (Magnani, 1996), de modo a buscar fazer uma verdadeira etnografia, mesmo ali onde o campo é a cidade. Esse tipo de etnografia urbana pretende buscar os padrões e regularidades das práticas sociais e do comportamento dos conjuntos de atores em espaços da cidade. A idéia é tentar apreender, descrever e analisar certos aspectos urbanos (principalmente relações construídas no dia-a-dia) difíceis de serem capturados nos enfoques metodológicos que abordam o empírico de fora e de longe. Porém, esse tipo de olhar não impede o pesquisador de articular a especificidade do seu objeto com outras questões para compreender fenômenos sociais mais abrangentes.

Se a escolha da observação participante pode (como de resto qualquer escolha) deixar lacunas, ela oferece, por outro lado, maior densidade às informações colhidas sobre as práticas e condutas, além de prover melhor apropriação para as questões relativas ao espaço vis-à-vis o que se obteria usando apenas a técnica das entrevistas convencionais, por exemplo. Claro está que a observação não descarta as conversas e as entrevistas, que também foram sistematicamente realizadas, mas, faz com que estas sejam ditadas pelos acontecimentos ou pela dinâmica de interação próprios da situação investigada. As interações sociais na situação de procura de trabalho foram primeiramente observadas, em um segundo momento elas foram temas-alvo de conversas informais com os atores daquela situação e em um terceiro momento foram detalhadamente questionadas em entrevistas com os atores que se mostraram mais relevantes ao delineamento da mesma situação.

Isto posto, passa-se a uma descrição do trabalho de campo, o qual se realizou em três fases diferentes. Essas três fases tinham objetivos diferentes, se realizaram a partir de engajamentos também distintos e fazendo uso de procedimentos diferenciados. Na seqüência apresentamos cada uma dessas fases do trabalho de campo, tentando evidenciar as decisões práticas que o construíram.

\footnotetext{
28 A atualização da noção de observação participante para o estudo de grupos ou situações sociais das sociedades contemporâneas não exige uma imersão ou isolamento, mas um contato o mais próximo possível com a realidade que se pretende estudar, atentando para o fato de que, contudo, como pesquisador, o objetivo não é misturar-se ou confundir-se aos observados e à realidade empírica, como alerta Foote-White (2005).
} 
Em alguma medida, faz-se também o exercício de reflexão sobre a construção desse processo, tentando captar o impacto que as características da situação investigada tiveram sobre ele. Convém registrar que, como soe acontecer num trabalho acadêmico, e para proteger as fontes, todos os nomes dos informantes são fictícios.

\subsection{Fase 1: as observações}

No início de 2007, começamos as visitas esporádicas à Rua Barão de Itapetininga e adjacências, local escolhido para a observação sistemática, pelas razoes já apontadas no capítulo anterior. $\mathrm{O}$ intuito era fazer observações exploratórias e acompanhar as transformações sofridas pelo espaço e pela dinâmica da situação. Como seria de esperar, antes de iniciar esta fase do trabalho, e mesmo no curso dela, foi empreendido um esforço sistemático de levantamento de material documental relativo à área escolhida, de sorte a produzir algum tipo de estranhamento ao observador, já agora municiado pela informação que permitia recompor o processo histórico de construção social do uso deste espaço. ${ }^{29}$

Nessa primeira fase, as observações se realizavam de forma que, após uma caminhada pela região, eu me localizava em pontos estratégicos da rua e observava, tentando apreender a dinâmica geral da situação, em seu conjunto de elementos, sem me deter propositadamente em nenhum deles. A caminhada parecia uma boa estratégia para engajar uma observação, pois:

"Pelo efeito de estranhamento que induz permite treinar e dirigir o olhar por uma realidade inicialmente tida como familiar e conhecida. Para tanto, deve obedecer a um timing que a distinga do andar apressado e alheio do usuário habitual, assim como do passante descomprometido. (...) O pesquisador, ao contrário, mesmo numa caminhada de reconhecimento, tem um plano preestabelecido, e seu caminhar (...) deve permitir uma observação contínua e seguir o fluxo do andar e parar. Caminhada sistemática, mas não exaustiva. A recomendação é deixar-se impregnar pelos estímulos sensoriais durante o percurso." (Magnani, 1996, pp. 37).

As caminhadas na Rua Barão de Itapetininga e outras ruas adjacentes, eram complementadas com visitas e observações no interior dos edifícios e galerias onde funcionam as agências de emprego e outros serviços conexos à atividade de procura de trabalho. Essa fase tinha intenção exploratória, e visava captar as características mais gerais da situação, objetivando especificamente: i) explorar as práticas típicas daquela dinâmica, ii) observar como essa dinâmica era influenciada pelo espaço, iii) captar mudanças na dinâmica de acordo com os dias da semana e os horários do dia e iv) apreender processos de transformação ao longo dos meses.

\footnotetext{
${ }^{29}$ Neste esforço, jornais de circulação nacional, documentos, registros fotográficos, materiais de grupos organizados de apoio à recuperação do Centro foram sistematicamente escrutinados. Contem, neste trabalho, com o apoio de Nathalia Leobas, bolsista de Iniciação Científica, a quem agradeço.
} 
Para tal, as visitas, distribuídas entre o início de 2007 e a metade de 2008, foram planejadas para se realizar em diferentes dias da semana e horários do dia. Pode-se dizer que nesse período, aproximadamente dez visitas foram realizadas, com duração de duas a três horas cada uma. As observações eram registradas num caderno de campo. Na maioria das vezes não usava o caderno para as anotações no próprio local da pesquisa para não suscitar a curiosidade ou desconfiança dos atores ali estabelecidos. Usava o interior de uma das galerias, a "Galeria Nova Barão", como espaço para as anotações, dado que aquele é, além de um ambiente relativamente tranqüilo em meio à grande agitação, o único local que dispõe de espaço para sentar - quatro banquinhos de ferro. As anotações e o caderno de campo foram fundamentais, pois se a etnografia não é mera descrição ou coleta de dados, as primeiras observações e anotações já contêm alguma interpretação e obedecem a algum princípio de orientação da análise.

Ainda que nessa fase exploratória o procedimento principal fosse a observação, quando um acontecimento específico chamava a atenção durante as visitas, tentava sondar suas causas com os próprios atores da situação (plaqueiros, camelôs, demandantes de trabalho ou transeuntes) através de conversas rápidas na própria rua. Nessas situações, as perguntas se relacionavam principalmente as questões referentes à rua, à dinâmica do espaço, ao mercado de intermediação ali operante, ao fluxo de movimento, aos serviços ali ofertados e a possíveis acontecimentos que tinham lugar. Porém, tais contatos eram circunstanciais e a observação foi o procedimento privilegiado nessa etapa, pois o que se buscava era conhecer melhor o espaço e apreender sua dinâmica geral.

Essa fase foi fundamental para a observação das características daquele espaço e para a identificação dos atores e das instituições que ali atuavam, assim como para mapear de maneira mais geral as práticas e as regras que orientam as interações, as condutas e a dinâmica daquela situação.

\subsection{Fase 2: as conversas}

Em uma segunda fase da pesquisa, realizei visitas mais longas, mais freqüentes e mais concentradas no tempo. Essa nova fase durou aproximadamente quinze dias, entre o fim de julho e o começo de agosto de 2008. Buscava, então, intensificar as observações, e, sobretudo, os contatos com os atores da situação de procura. A intenção era não somente observar, mas aumentar a comunicação com aqueles diversos agentes, aproximando-me deles para entender a forma como participavam daquela situação e como falavam sobre sua participação. Embora apresentando-me na condição de estudante ou de pesquisadora, passara a tomar parte daquela situação; assim sendo, a 
minha interação com aqueles atores (e potenciais informantes) era, como deve ser em uma observação participante, impregnada ou ditada pela dinâmica, pelo ritmo e pela vivência - deles e minha - da situação em questão.

A característica dessa segunda fase foi o investimento mais focado nas conversas, as quais se somaram às observações, que continuaram sendo realizadas. Essas conversas eram ditadas pela dinâmica da situação; não estavam baseadas em um roteiro de questões pré-definido, mas eram completamente pautadas pelo objetivo de entender como os diferentes atores atuam naquela situação de procura. Ainda que informais, essas conversas eram orientadas por certas diretrizes básicas. Procurava investigar melhor acerca da participação, atuação e função que cada um dos agentes desenvolve no processo de procura de trabalho que ali se desenvolve. Entender a configuração do espaço era outra diretriz: tal configuração foi, então, mais detalhadamente observada; o modo de apropriação do espaço, tal como feito por cada um dos personagens pôde ser tomado como objeto nas conversas. Elucidar o funcionamento do mercado de intermediação que ali opera, foi outra diretriz que animou temas correntemente tratados nas conversas. A própria procura de trabalho passou a ser mais focalizada, seja nas observações, seja nas conversas nessa fase da pesquisa empírica. As práticas e os códigos que regem as interações na procura de trabalho começaram a ser investigados a partir dos discursos dos atores, assim como as características das instituições de intermediação e dos demandantes de trabalho.

Conversas foram realizadas com os mais diversos atores que ali circulam e se apropriam daquele espaço, mesmo se não estivessem envolvidos na dinâmica de procura de trabalho. Eram eles: demandantes de trabalho, vendedores ambulantes, plaqueiros, funcionários das agências de emprego e de outros estabelecimentos comerciais, agentes da Guarda Metropolitana, membros da Polícia Militar e funcionários da Sub-Prefeitura da Sé. As observações da fase anterior mostraram que esses personagens faziam uso freqüente e regular daquele espaço, nele desempenhando atividades diversas e, por isso mesmo, poderiam fornecer informações relevantes sobre a dinâmica do lugar. Foi possível conversar nessa fase com cerca de quarenta informantes ${ }^{30}$, contemplando a variedade de personagens do local, de acordo com a disponibilidade, a disposição e o interesse dos mesmos, e, por isso mesmo, essas conversas tinham duração de tempo muito variável. A tabela abaixo mostra a distribuição das conversas por tipo de informante e indica os locais em que esses foram abordados e onde as conversas transcorreram.

\footnotetext{
${ }^{30}$ Devido às características intrínsecas dessa fase da pesquisa, onde cada conversa mais breve e despretensiosa é um contato, e, por vezes, muito valioso, é extremamente difícil precisar o número exato de informantes. Esse número aproximado está baseado nas anotações do diário de campo.
} 


\section{Quadro 2.1: Distribuição das conversas por tipo de informante e local de abordagem}

(julho/agosto 2008)

\begin{tabular}{|l|l|l|}
\hline Tipo de informante & $\mathbf{N}^{\mathbf{0}}$ de informantes & Abordagem e realização da conversa \\
\hline Demandantes de trabalho & 15 & Rua, Fila, Corredores dos edifícios e galerias. \\
\hline Plaqueiros & 7 & Rua. \\
\hline Funcionários de agências & 6 & Agências \\
\hline Guarda Metropolitana & 2 & Rua \\
\hline Polícia militar & 2 & Rua \\
\hline Fiscal da Sub-Prefeitura da Sé & 1 & Rua \\
\hline Vendedores ambulantes & 3 & Rua \\
\hline Empregado da banca de jornal & 2 & Bancas de jornal \\
\hline Segurança do Ed. Rio Branco & 1 & Rua .Lado de fora do Ed. Rio Branco. \\
\hline
\end{tabular}

Fonte: Levantamento de campo, 2008.

A aproximação com os informantes deu-se, a princípio, através de perguntas despretensiosas sobre o movimento do local ou sobre algo relacionado ao trabalho de cada um deles (quando se tratava de alguém que exercia seu trabalho no local), ou ainda sobre algo relacionado a algum anúncio de vaga de trabalho (quando se tratava de alguém à procura de trabalho) com a intenção de desencadear alguma interação. Na rua, ao notar no potencial informante alguma disponibilidade ou disposição para estabelecer uma conversa, eu me apresentava como estudante que realizava pesquisa sobre procura de trabalho e dava início a um contato mais direcionado, ainda que nesse momento a intenção fosse menos a de estabelecer uma dinâmica de perguntas e respostas e mais a de entabular uma conversa exploratória. No caso dos funcionários das agências, a interação era mais direta, pois ao entrar na agência, já me apresentava como pesquisadora e pedia autorização para uma conversa, sem a possibilidade de sondar, a priori, a disposição do informante. As conversas se realizaram, via de regra, no mesmo local em que foram abordados os informantes. A maior parte das interações com os informantes se deu na própria rua, em horários e dias diversificados, porém concentrados nos quinze dias que durou essa segunda fase, entre o fim de julho e o começo de agosto de 2008. Alguns demandantes, no entanto, foram abordados no interior de algum edifício ou galeria em que procuravam trabalho e os funcionários das agências foram todos abordados dentro dos locais de trabalho. Como o que se pretendia nesta fase era delinear primeiros achados e captar elementos importantes sobre aquela situação e atuação dos personagens naquela dinâmica, certas características desses personagens deixaram de ser apreendidas. Assim não foram captadas, por exemplo, informações suficientes que nos permitisse caracterizar do ponto de 
vista sócio-econômico esses informantes. Tais elementos seriam investigados em maior detalhe e mais sistematicamente na fase seguinte da pesquisa de campo.

Essa fase permitiu avançar bastante no delineamento interpretativo da situação de procura de trabalho. Em primeiro lugar, foi possível identificar as instituições e os atores envolvidos de maneira mais direta na procura de trabalho. Foi possível também avançar na captação das regras de interação entre eles e dos códigos da conduta de cada um. Discursos muito interessantes sobre as relações entre os atores permitiram vislumbrar as expectativas, os conflitos e as negociações que nelas estavam envolvidas. No que diz respeito aos demandantes especificamente, surgiram nessas conversas muitos temas diretamente relacionados à experiência da procura de trabalho, tais como seus significados, e as dificuldades e expectativas que lhe constituem. Por isso, uma série de questões que se mostraram importantes nessa etapa das conversas informais foram aprofundadas e detalhadas na fase posterior da pesquisa empírica, pois puderam ser incorporadas aos roteiros de entrevistas. Os achados dessa fase foram explorados na etapa seguinte.

\subsection{Fase 3: as entrevistas}

A terceira fase do trabalho de campo se realizou entre dezembro de 2008 e março de 2009. Essa fase de trabalho foi composta por três procedimentos: observações, pesquisa na internet e entrevistas.

A principal característica dessa terceira fase da pesquisa empírica foi o investimento nos contatos com os atores principais daquela situação para a realização de um conjunto de entrevistas direcionadas por perguntas-chave, elaboradas a partir do conhecimento acumulado na fase anterior. Os atores tomados como privilegiados para essas entrevistas foram aqueles que, tal como também foi possível identificar na fase anterior, desempenhavam papel vital na dinâmica da procura de trabalho naquela situação, quais sejam: funcionários das agências de emprego, funcionários dos estabelecimentos que ofertam serviços correlatos à procura de trabalho, plaqueiros e demandantes de trabalho. A importância de cada um deles na situação e a pertinência de investigá-los mais a fundo serão detalhadas no capítulo seguinte.

Esses atores foram entrevistados com base em roteiros semi-estruturadas. Apesar de guiadas, as interações com os informantes, ainda nessa fase, tiveram um caráter informal. Após algumas tentativas de abordagem usando a palavra "entrevista", retornei ao uso da palavra "conversa", devido à grande resistência das pessoas com relação à primeira palavra. Entretanto, apesar do uso da palavra conversa, o que se realizou nessa fase foram entrevistas. Cada entrevista seguia sua 
dinâmica própria, mas era orientada pelo roteiro de perguntas, o qual deveria estar na mente da pesquisadora. Quando havia disponibilidade de tempo por parte dos entrevistados um conjunto mais completo de questões era formulado. Quando havia restrição de tempo, algumas perguntas do roteiro eram suprimidas. Em alguns casos de restrição de tempo, as entrevistas foram realizadas em duas partes, em dias diferentes, como ocorreu com plaqueiros e funcionários das agências. Improvisos e mudanças na rota das entrevistas eram bem-vindos se pudessem acrescentar informações interessantes, assim como poderiam ser reorientados no caso de desvios muito grandes dos temas pertinentes à pesquisa.

Foram realizadas nessa fase da pesquisa 51 entrevistas sendo: 24 entrevistas com demandantes de trabalho, 7 entrevistas com plaqueiros, 11 entrevistas com funcionários de agências de emprego, 7 entrevistas com funcionários dos estabelecimentos que ofertam serviços correlatos à procura de trabalho.

\section{Quadro 2.2. Distribuição das entrevistas por tipo de informante (dez/2008 - mar/2009)}

\begin{tabular}{|l|l}
\hline Tipo de informante & $\begin{array}{l}\mathbf{N}^{\mathbf{0}} \text { de } \\
\text { informantes }\end{array}$ \\
\hline Demandantes de trabalho & 24 \\
\hline Plaqueiros & 7 \\
\hline Funcionários de agências & 11 \\
\hline Funcionários serviços correlatos à procura & 7 \\
\hline
\end{tabular}

Fonte: Levantamento de campo, 2008-2009.

As entrevistas dessa terceira fase também se distribuíram em dias e horários diversificados. Sem a pretensão da representatividade típica dos estudos quantitativos, tentou-se, contudo, buscar uma certa variedade entre os tipos de entrevistados. No que diz respeito aos demandantes, buscou-se uma variedade no que diz respeito à idade, sexo e cor. No que diz respeito aos plaqueiros, buscou-se uma variedade no que diz respeito ao tipo de atuação que eles desenvolviam e o tipo de estabelecimento para o qual trabalhavam. Já no que diz respeito às agências de emprego e aos estabelecimentos que ofertam serviços correlatos à procura, buscou-se uma variedade no que diz respeito às características da firma e dos serviços ofertados. Porém, ao final, a disponibilidade e a cooperação dos atores abordados é o que acabou determinando a configuração de cada grupo de entrevistados.

As entrevistas buscavam responder a algumas questões sobre a atuação de cada ator e seus efeitos no delineamento geral da situação. Tais questões mais amplas orientaram a construção dos 
roteiros de entrevistas e todas as entrevistas realizadas nessa fase tinham o objetivo de captar informações a respeito desses tópicos mais gerais. Porém, algumas perguntas mais específicas a cada tipo de ator se faziam pertinentes e relevantes. Assim, foram construídos roteiros diferentes para cada tipo de ator investigado, buscando responder esses questionamentos mais amplos sobre o papel na situação de procura, mas também as perguntas mais específicas às práticas de cada um deles. Os roteiros de entrevista que guiaram a interação com cada tipo de ator serão apresentados ao longo do capítulo, mas os temas principais e comuns a todos os roteiros de entrevistas específicos, são as seguintes:

\section{Quadro 2.3. Temas comuns a todos os roteiros de entrevistas}

1)Quais as principais características sociais de cada tipo de ator da situação de procura?

2) Quais as principais diferenças entre atores do mesmo tipo no que diz respeito à atuação e características sociais?

3)Como atua na situação de procura? Qual papel exerce na situação? Quais práticas desempenha?

4)Relação de cada ator com o espaço. Formas de apropriação.

5)Interação com os outros atores. Códigos, expectativas e técnicas que pautam as interações.

6)Discurso e percepções sobre os códigos de conduta mobilizados e julgados na procura de trabalho.

Fonte: Levantamento de campo, 2008-2009.

Esses temas se desdobravam em perguntas que tinham como objetivo entender o papel do ator, suas práticas, conduta, como ele se apropria do espaço e como e com quem estabelece interações.

Com base nesse roteiro geral, para cada um dos quatro principais grupos de atores da situação foi elaborado um roteiro de entrevista específico e uma forma particular de abordagem. A interação com cada um desses grupos era permeada por características específicas e dificuldades particulares para a abordagem. Na seqüência apresentam-se os roteiros específicos que guiaram as entrevistas, assim como as estratégias de abordagem traçadas, as dificuldades que surgiram na realização das entrevistas, as estratégias de contorná-las e as características das interações entre cada grupo de entrevistados e a pesquisadora. As entrevistas não foram gravadas, mas exaustivamente registradas nos cadernos de campo. A opção de não gravar foi feita após algumas recusas e após a percepção de que seria praticamente impossível operar um gravador e fazer anotações ao mesmo tempo, isso porque a grande maioria das entrevistas se deu no meio da rua, em meio a muito barulho, de pé, e sem apoio. Além disso, pela ausência de uma relação previamente estabelecida entre entrevistador e entrevistado e dada a necessidade de criar uma relação de empatia e confiança em meio ao próprio curso da entrevista, acredita-se que o gravador inibiria discursos e enfatizaria para o informante o tom de "entrevista" daquela interação e não o de "conversa", por eles preferido e, por isso mesmo, por mim enfatizado na abordagem. Tomada a decisão de não gravar as entrevistas realizadas na rua, 
essa decisão foi estendida para as entrevistas realizadas dentro de agências de emprego e demais estabelecimentos comerciais, pela constatação de que essa estratégia havia permitido, mesmo na rua e em condições adversas, discursos muito ricos e espontâneos. Mas, as informações eram exaustivamente anotadas durante e após as entrevistas, buscando, sempre que possível, anotar os discursos literais dos informantes, tal como expressos em suas próprias palavras ou o mais próximo possível de suas palavras.

Quatro grupos de atores foram entrevistados. As entrevistas de cada grupo foram realizadas a partir de um mesmo roteiro e sob condições, abordagens e constrangimentos semelhantes. Apresentamos a seguir o processo de realização de cada um desses quatro conjuntos de entrevistas, começando pelo grupo dos atores ligados as agências de emprego, seguindo por aqueles que ofertam serviços conexos à procura de trabalho, passando para os plaqueiros e encerrando com os demandantes de trabalho. As entrevistas não são descritas na ordem cronológica em que foram realizadas.

\subsubsection{Agências de emprego}

As agências de emprego, instituições fundamentais à dinâmica daquela situação, foram investigadas através de entrevistas com seus funcionários, assim como por meio de pesquisas em suas páginas na internet e de observações de suas instalações e do seu modo de funcionamento. Nas agências de emprego, as entrevistas foram realizadas, predominantemente, com dois tipos de funcionários, os quais se mostraram mais fundamentais à dinâmica da situação e os quais estabelecem relações diretas com os demandantes de trabalho. São os funcionários que trabalham na recepção da agência e na seleção dos candidatos. Além disso, supervisores e gerentes também foram entrevistados.

Caracterizar essas agências foi um alvo das entrevistas com seus funcionários. Isso porque, partiu-se do pressuposto de que esses atores falam a partir de um lugar social específico, a instituição em que trabalham; que eles interagem com os demandantes a partir das regras de funcionamento dessa instituição; e que eles dão voz às representações desta. Algumas questões de caracterização foram introduzidas nos roteiros de entrevistas utilizados com os funcionários de agências, articuladas às questões gerais do roteiro básico. No que diz respeito às agências, buscouse entender mais sobre os serviços ofertados, tipos de vagas intermediadas, tipo de demandante que atraem, tipo de demandante que gostariam de atrair, qual o tipo de cliente atrai, dificuldades que enfrentam, estratégias de divulgação das vagas e captação de candidatos e operacionalização dos 
processos seletivos, número de funcionários e de filiais. Além disso, buscou-se entender melhor o que essas instituições esperam de um bom demandante de trabalho. O roteiro aplicado ao grupo dos funcionários das agências é o que segue abaixo. Nas entrevistas com as recepcionistas algumas questões eram mais exploradas, enquanto nas entrevistas com os selecionadores outras questões eram investigadas em mais detalhe.

Quadro 2.4. Roteiro de entrevista aplicado aos funcionários das agências de emprego.

1)Perfil da agência, quais as suas principais características: número de funcionários, de filiais, serviços ofertados, principais clientes, como é a relação com os clientes

2)Como a empresa opera, como é a sua dinâmica de funcionamento.

3)Por que atua aqui nesse espaço? Quais as vantagens e desvantagens de atuar aqui?

4)Tem filiais em outros espaços da cidade? Qual a diferença dessa filial para a (s) outra(s)?

5)Quais os tipos de vagas ofertadas? Quais as vagas mais comuns?

6)Contratam plaqueiros? Quantos? Por quê? Qual o papel desse funcionário na dinâmica da agência? Quais as orientações dadas a ele?

7)Como capturam os demandantes de trabalho?

8)Qual o tipo de demandante procura? Qual tipo de demandante atrai?

9)Como funcionam os processos seletivos?

10)O que se espera de um bom candidato?

11)O que é inadmissível em um candidato e o coloca fora da concorrência pelas vagas?

12)Poderia me dar exemplo de um bom currículo? E de um currículo ruim?

13)Quais as maiores dificuldades na atuação da empresa? O que se faz para superar essas dificuldades?

Fonte: Levantamento de campo, 2009.

A princípio, foi traçada uma estratégia de eleger alguns tipos de agências que se tornariam alvo de investigação mais sistemática. Esse conjunto foi delineado levando em conta seu porte e estrutura, suas características de atuação e os tipos de serviços ofertados. Porém, houve muitas recusas, adiamentos e cancelamentos de entrevistas, especialmente daquelas solicitadas aos funcionários das agências pequenas, as quais representam grande parte das empresas que constituem aquele mercado de intermediação territorializado. Por isso, as agências pequenas estão subrepresentadas aqui. Esse problema tentou ser contornado através de pesquisas na internet e perguntas sobre as características de operação dessas agências menores formuladas àqueles que concederam entrevistas e que, por trabalharem naquele mercado, conhecem a atuação de suas concorrentes. Foram entrevistados funcionários de seis agências diferentes, que apresentam semelhanças e diferenças que se revelaram interessantes para a análise. Houve em alguns casos observações in loco do funcionamento da empresa, da operação dos serviços e da interação com os outros atores da situação, como a interação entre recepcionista e demandante de trabalho. Assim, foi possível observar de perto, com a devida autorização dos responsáveis, momentos muito importantes da procura de trabalho como o processo de apresentação dos candidatos às recepções 
das agências e parte de um processo seletivo de uma agência recrutando candidatos. Segue quadro com características das agências que foram alvo de investigação e detalhamento dos funcionários que foram entrevistados.

\section{Quadro 2.5 . Distribuição de observações e entrevistas por agência analisada}

\begin{tabular}{|c|c|c|c|c|c|}
\hline Agência & $\begin{array}{l}\text { Localizaçã } \\
\quad \text { o }\end{array}$ & Características & $\begin{array}{l}\text { Funcionários } \\
\text { entrevistados }\end{array}$ & $\begin{array}{c}\text { Observação } \\
\text { na agência }\end{array}$ & $\begin{array}{l}\text { Data das } \\
\text { observs. }\end{array}$ \\
\hline Agencia 1 & $\begin{array}{l}\text { R. Barão de } \\
\text { Itapetininga }\end{array}$ & $\begin{array}{l}\text { Porte médio. Bem } \\
\text { estruturada. } \\
\text { Grande diversidade de tipos } \\
\text { de vagas intermediadas. O } \\
\text { foco é a intermediação. }\end{array}$ & $\begin{array}{l}\text {-Coord. de seleção } \\
\text {-Recepcionista }\end{array}$ & $\begin{array}{l}\text { Sala de } \\
\text { recepção }\end{array}$ & $\begin{array}{l}04 / 03 / 09 \\
06 / 03 / 09\end{array}$ \\
\hline Agencia 2 & $\begin{array}{l}\text { R. Barão de } \\
\text { Itapetininga }\end{array}$ & $\begin{array}{l}\text { Porte médio. Intermediação } \\
\text { de estágios exclusivamente. } \\
\text { Empresa em expansão. }\end{array}$ & $\begin{array}{l}\text {-Coord. de } \\
\text { treinamento e } \\
\text { desenvolvimento } \\
\text {-Coord. de } \\
\text { assessoria de } \\
\text { imprensa } \\
\text {-Selecionadora }\end{array}$ & $\begin{array}{l}\text { Sala de } \\
\text { recepção }\end{array}$ & $05 / 03 / 09$ \\
\hline Agencia 3 & $\begin{array}{l}\text { R. Barão de } \\
\text { Itapetininga }\end{array}$ & $\begin{array}{l}\text { Porte pequeno. Intermediação } \\
\text { e terceirização. } \\
\text { Especialmente para vagas de } \\
\text { telemarketing e outras vagas } \\
\text { operacionais. }\end{array}$ & $\begin{array}{l}\text {-Coord. de seleção } \\
\text {-Recepcionista }\end{array}$ & $\begin{array}{l}\text { Sala de } \\
\text { recepção }\end{array}$ & $13 / 03 / 09$ \\
\hline Agencia 4 & $\begin{array}{l}\text { R. Barão de } \\
\text { Itapetininga }\end{array}$ & $\begin{array}{l}\text { Porte médio. Exclusivamente } \\
\text { intermediação para vagas de } \\
\text { operador de telemarketing }\end{array}$ & $\begin{array}{l}\text {-Coord, de seleção } \\
\text {-Estagiária de } \\
\text { seleção }\end{array}$ & $\begin{array}{l}\text { Sala de } \\
\text { recepção e } \\
\text { acompanhame } \\
\text { nto de parte do } \\
\text { processo } \\
\text { seletivo } \\
\end{array}$ & $\begin{array}{l}05 / 03 / 09 \\
06 / 03 / 09\end{array}$ \\
\hline Agencia 5 & $\begin{array}{l}\text { R. } 24 \text { de } \\
\text { Maio }\end{array}$ & $\begin{array}{l}\text { Porte grande. Grande } \\
\text { diversidade de tipos de vagas } \\
\text { intermediadas e de serviços } \\
\text { oferecidos. Filial da maior } \\
\text { rede de agencias do país. }\end{array}$ & -Recepcionista & Não & -- \\
\hline Agencia 6 & R. Marconi & $\begin{array}{l}\text { Pequena e precária. Vagas } \\
\text { operacionais }\end{array}$ & -Recepcionista & Não & \\
\hline
\end{tabular}

Fonte: Levantamento de campo, 2009.

Todos os funcionários de agências foram abordados dentro desses estabelecimentos em seus horário de trabalho. Propunha-se uma conversa sobre procura de trabalho e sobre a operação daquela empresa, ressaltando a possibilidade de que essa conversa se realizasse no horário e local mais convenientes ao informante. Das quatro recepcionistas, duas só concederam a entrevista após a 
permissão de seus superiores; uma concedeu a entrevista mesmo sem pedir permissão; outra disse que preferia dar a entrevista fora da agência, pois sabia que não teria permissão. Os funcionários da área de seleção, por sua maior autonomia, concederam entrevistas sem a necessidade de pedido de permissão a superiores. Quase todas as entrevistas concedidas por esses funcionários se realizaram no interior da própria agência. Ali, informante e pesquisadora interagiam sentados, com mais conforto, inclusive para as anotações no caderno de campo. Talvez, por isso, essas entrevistas duraram mais tempo, de 45 minutos a duas horas. Por disponibilidade de tempo dos informantes, algumas entrevistas se realizaram em duas fases, em dias ou horários diferentes. Uma das recepcionistas preferiu realizar a primeira parte da entrevista do lado de fora da agência, no horário de seu lanche. A recepcionista que não pediu permissão aos superiores concedeu entrevista que foi divida em duas partes, ambas realizadas na rua, do lado de fora da agência, uma em seu horário de almoço e outra após sua jornada de trabalho. As entrevistas com esse grupo de entrevistados se distribuíram tal como mostra a tabela abaixo:

\section{Quadro 2.6. Entrevistas com funcionários de Agências de Emprego (março/ 2009)}

\begin{tabular}{|c|c|c|c|c|c|c|}
\hline Nome & Idade & Função & Agencia & Local da entrev. & Data da entrev. & Entrevistas \\
\hline Juliana & 19 & Recepcionista & Agencia 1 & $\begin{array}{ll}\text { Corredor } & \text { do } \\
\text { edifício } & \\
\text { Agência } & \end{array}$ & $04 / 03 / 09$ & 2 \\
\hline Paty & 20 & Recepcionista & Agencia 3 & Agência & $13 / 03 / 09$ & 1 \\
\hline Ana & 20 & Recepcionista & Agencia 5 & $\begin{array}{l}\text { Agência } \\
\text { Rua (do lado de } \\
\text { fora da agência) }\end{array}$ & $\begin{array}{l}06 / 03 / 09 \\
12 / 03 / 09\end{array}$ & 2 \\
\hline Fabiana & 22 & Recepcionista & Agencia 6 & Agência & $12 / 03 / 09$ & 1 \\
\hline Heloísa & 35 & Selecionadora & Agencia 1 & Agência & 06/03/09 & 1 \\
\hline Tânia & 40 & Selecionadora & Agencia 2 & Agência & $05 / 03 / 09$ & 1 \\
\hline Ricardo & 30 & Selecionadora & Agencia 3 & Agência & $13 / 03 / 09$ & 1 \\
\hline Carolina & 27 & Selecionadora & Agencia 4 & Agência & $\begin{array}{l}05 / 03 / 09 \\
06 / 032009\end{array}$ & 2 \\
\hline Paula & 22 & $\begin{array}{l}\text { Estagiária de } \\
\text { seleção }\end{array}$ & Agencia 4 & Agência & $05 / 03 / 09$ & 1 \\
\hline Carla & 40 & $\begin{array}{l}\text { Coordenadora } \\
\text { de } \\
\text { desenvolvime } \\
\text { nto e } \\
\text { treinamento }\end{array}$ & Agencia 2 & Agência & $05 / 03 / 09$ & 1 \\
\hline Mario & 35 & $\begin{array}{l}\text { Coordenador } \\
\text { de assessoria } \\
\text { de imprensa } \\
\end{array}$ & Agencia 2 & Agência & $05 / 03 / 09$ & 1 \\
\hline
\end{tabular}

Fonte: levantamento de campo, 2009. 
Duas foram as principais dificuldades encontradas na realização das entrevistas com esse grupo de atores foram duas: entrevistar funcionários de agências pequenas e conseguir permissão para entrevistar funcionários da filial da maior rede de agências de emprego do país (que opera também naquele cluster). No mais, as entrevistas concedidas transcorrem sem grandes dificuldades, as interações com os informantes foram amistosas e muitos demonstraram muita vontade em colaborar.

\subsubsection{Serviços conexos à procura de trabalho}

$\mathrm{Na}$ fase 2 da pesquisa de campo foi possível perceber que alguns serviços eram muito utilizados pelos demandantes de trabalho. Eles estavam, alguns mais outros menos, relacionados à atividade de procura de trabalho e se tornavam, em alguns casos, fundamentais para que a própria procura se realizasse. São os serviços conexos à procura de trabalho, tais como lan houses, xerox, elaboração de currículos, agências financiadoras de crédito, cursos preparatórios para processos seletivos, cursos preparatórios para concursos públicos, advogados e médicos trabalhistas, entre outros. Pela importância desses serviços para os demandantes e para a dinâmica da situação, esses estabelecimentos passaram a configurar, junto com as agências, instituições-chave para o entendimento da situação de procura. Buscou-se entender um pouco mais sobre eles a partir de entrevistas com seus funcionários, de observações e de relatos dos demandantes, que são os potenciais clientes desses serviços.

Nesses estabelecimentos comerciais que oferecem serviços correlatos à procura, as entrevistas foram feitas com aqueles funcionários que desempenhavam a função de atender o público e realizar o serviço ofertado; as razoes para tal advinham do reconhecimento da interação mais direta que eles estabelecem com os clientes e da influência que eles podem ter sobre o processo de realização do serviço. Para as entrevistas com os funcionários desses estabelecimentos não houve a preparação de um roteiro específico e único, pois cada tipo de estabelecimento oferta um tipo de serviço e possui uma forma diversa de funcionamento e operação. Essas entrevistas foram baseadas em perguntas mais gerais sobre a operação do estabelecimento, os serviços ofertados e a dinâmica de interação desses funcionários com os demandantes, seus principais clientes. O roteiro geral que guiou as entrevistas com os funcionários desses estabelecimentos diversos segue abaixo: 
Quadro. 2.7. Roteiro de entrevistas aplicado aos estabelecimentos que ofertam serviços correlatos à procura

1)Perfil do estabelecimento. Como funciona? Quais serviços são oferecidos? Horário de funcionamento? Preço dos serviços? Quantos funcionários?

2)Qual é o principal tipo de cliente? As pessoas à procura de trabalho representam o maior número de clientes que usam os serviços? Há uma clientela que vem com freqüência?

3)Como é o movimento?Algum dia da semana ou horário do dia mais movimentado?

4)Como é a interação entre os clientes e funcionários?

5)Os clientes pedem dicas ou informações referentes à procura de trabalho? Quais são as informações requeridas?

6)Há interação entre os clientes?

7)Como os clientes chegam até aqui? Tem divulgação na rua? Plaqueiro? Panfleteiro?

8)Quais as vantagens e desvantagens de atuar nesse espaço?

9)Tem filiais? Onde? Se sim, qual a diferença dessa unidade da Barão para a(s) outra(s)?

Fonte: levantamento de campo, 2009.

Foram entrevistados sete funcionários desses estabelecimentos, sendo que dois trabalhavam na elaboração de currículos, dois trabalhavam como atendentes em lan houses, dois eram promotores de rua de uma agência financiadora de crédito e um trabalhava na recepção de um estabelecimento que oferece cursos preparatórios para concurso público.

Além das entrevistas, foram empreendidas observações no interior desses estabelecimentos que nos permitiram captar mais sobre sua operação e sobre as interações lá estabelecidas. Assim, foi possível observar de perto, momentos muito importantes da procura de trabalho realizada naquele espaço tais como o processo de confecção de currículos e o processo de procura virtual em lan houses. Cada um desses funcionários concedeu uma entrevista, a qual se realizou no mesmo dia da observação, quando houve. Essas entrevistas e observações se realizaram em janeiro de 2009.

Quadro 2.8. Distribuição de entrevistas e observações nos estabelecimentos que ofertam serviços conexos à procura por tipo de estabelecimento (janeiro/2009)

\begin{tabular}{|l|l|l|l|l|}
\hline \multicolumn{1}{|c|}{ Tipo de estabelecimento } & \multicolumn{1}{|c|}{ Entrevistado } & $\begin{array}{c}\mathbf{N}^{\mathbf{0}} \text { de } \\
\text { entrevistados }\end{array}$ & Observação interna & Data \\
\hline Elaboração de currículo 1 & Atendente & 1 & Sim & $22 / 01 / 09$ \\
\hline Elaboração de currículo 2 & Atendente & 1 & Não & $22 / 01 / 09$ \\
\hline Lan house 1 & Atendente & 1 & Sim & $27 / 01 / 09$ \\
\hline Lan house 2 & Atendente & 1 & Sim & $27 / 01 / 09$ \\
\hline Curso prep. concurso público & Recepcionista & 1 & Não & $27 / 01 / 09$ \\
\hline
\end{tabular}

Fonte: Levantamento de Campo, 2009.

Os funcionários desses estabelecimentos foram abordados no interior dos mesmos, durante horário de trabalho. No caso das lan houses e estabelecimentos que elaboram currículos, após as 
entrevistas foi feito o pedido para realizar observações no local. Das quatro tentativas, houve apenas uma recusa. Essas abordagens foram feitas em momentos que o movimento dos estabelecimentos era pequeno, para que não atrapalhasse o trabalho dos informantes. Em alguns casos, as entrevistas precisaram ser momentaneamente interrompidas para que eles realizassem alguma atividade ou atendessem algum cliente, momentos em que se aproveitava a oportunidade para observar. Todos os funcionários desse grupo que concederam entrevista, o fizeram sem pedir permissão para o supervisor, até porque na maioria desses casos nem há um supervisor que esteja constantemente no estabelecimento. Foram prontamente recusadas ou canceladas cerca de sete entrevistas sob a alegação de falta de tempo ou de permissão do supervisor. Segue abaixo tabela com as informações sobre as entrevistas realizadas com esse grupo de atores.

Quadro 2.9. Entrevistas com funcionários dos estabelecimentos que ofertam serviços conexos à procura

\begin{tabular}{|l|l|l|l|l|}
\hline Nome & Função & Estabelecimento & Idade & Data \\
\hline Raquel & Atendente & Elaboração de CV 1 & 25 & $22 / 01 / 09$ \\
\hline Anderson & Atendente & Elaboração de CV 1 & 22 & $22 / 01 / 09$ \\
\hline Bruna & Atendente & Lan house 1 & 20 & $27 / 01 / 09$ \\
\hline Marcos & Atendente & Lan House 2 & 27 & $27 / 01 / 09$ \\
\hline Lílian & Recepcionista & Curso Concurso Público & 30 & $27 / 01 / 09$ \\
\hline Marta & Promotor & Ag. Financiadora Crédito & 22 & $22 / 01 / 09$ \\
\hline Michel & Promotor & Ag. Financiadora Crédito & 20 & $22 / 01 / 09$ \\
\hline
\end{tabular}

Fonte: Levantamento de campo, 2009.

Foi possível coletar mais informações sobre esses estabelecimentos que ofertam serviços correlatos à procura através dos depoimentos dos demandantes de trabalho, que são os potenciais clientes dessas firmas. Essa complementação de informação através dos demandantes que já utilizaram alguns desses serviços foi muito importante, primeiro, para tentar driblar as lacunas das variadas recusas e, segundo, porque a diversidade e pluralidade dessas firmas é muito grande e não seria possível, dentro dos limites dessa pesquisa, fazer uma investigação mais exaustiva desse mercado. A dificuldade de apreender tal diversidade foi o principal obstáculo encontrado na investigação desses estabelecimentos, razão pela qual as entrevistas foram focadas em alguns tipos deles. Porém, na análise realizada no capítulo seguinte são descritos também, com base em observações e relatos de clientes, outros tipos de serviços e estabelecimentos.

\subsubsection{Plaqueiros}


Os plaqueiros, personagens que se mostraram, desde as primeiras observações, fundamentais à dinâmica daquela situação de procura e vitais ao funcionamento das agências que ali atuam, serão aqui tratados como integrantes de um grupo de atores específicos da situação investigada, ainda que sejam eles próprios funcionários das agências de emprego. Eles divulgam vagas de trabalho na rua, mas também desempenham, na rua ou no interior das agências, outras funções, tal como será tratado no capítulo seguinte. Eles estão ligados às agências de emprego, mas desenvolvem seu trabalho principal na rua, onde estabelecem interações muito peculiares com os demandantes de trabalho e com outros personagens que se apropriam daquele espaço. As relações de apropriação do espaço, as interações com os demandantes e outros personagens, as práticas de atuação, as orientações recebidas das agências e as funções que desempenham dentro delas foram questões investigadas nas entrevistas com esses atores, tal como pode ser observado no roteiro de entrevistas a seguir apresentado:

\section{Quadro 2.10. Roteiro de entrevista aplicado aos plaqueiros}

1)Como é o trabalho? Qual a rotina? Quais atividades? Quais as orientações que a agência dá?

2)Há quanto tempo trabalha como plaqueiro? Há quanto tempo trabalha naquela região?

3)Quais as maiores dificuldades desse trabalho? O que vc faz para superar essas dificuldades?

4)Como é o trabalho na rua? Fica aqui parado ou circulando? Qual é a melhor parte da rua pra ficar ou circular? Por quê?

5)Aborda os demandantes na rua ou espera que eles se aproximem?

6)Como é a relação com os demandantes? Há conversas? Pedidos de dicas, informações, favores?

7)Recolhe currículos? Faz uma pré-seleção antes de levar par agência? Quais são os critérios considerados nessa seleção? Quais as orientações da agência?

8)Como deve ser um bom candidato? Como ele deve se vestir e se comportar?

9)Como deve ser um bom currículo? E um currículo ruim?

10)Como é a relação com os outros plaqueiros? E com os policiais? E com os camelôs?

11)Algo mudou no trabalho depois do Projeto Cidade Limpa? O que?

12)Há uma clientela ou grupo de demandantes que voltam com freqüência e que podem acionados quando surgem certos tipos de vaga?

13)Há a prática de divulgação das vagas que a agencia oferece para os seus amigos, parentes e vizinhos? A agência estimula esse tipo de prática? Como funciona?

Fonte: levantamento de campo, 2009.

Os plaqueiros foram abordados na rua, durante sua jornada de trabalho. Essa abordagem era feita em momentos em que o movimento na rua estava pequeno (principalmente às quintas e sextas, no fim da tarde) para não atrapalhar o trabalho dos informantes e aumentar a probabilidade de uma resposta positiva ao pedido de entrevista. No momento da abordagem, além de me apresentar como pesquisadora, propor uma conversa sobre procura de trabalho naquele espaço, eu ressaltava que essa poderia se realizar em outro momento ou outro lugar, de acordo com a preferência do informante. 
Quatro dos sete entrevistados desse grupo aceitaram conceder a entrevista na rua durante a atividade de trabalho, os outros três pediram que ela se realizasse após o fim da jornada de trabalho. Dessas três entrevistas, uma se realizou na rua mesmo, outra se realizou numa galeria da região, e a outra se realizou em duas partes, sendo a primeira na rua e a segunda em uma lanchonete. As entrevistas com os plaqueiros duravam cerca de uma hora cada uma. Aquelas realizadas durante a atividade de trabalho na rua podiam ser momentaneamente interrompidas por alguma demanda das pessoas à procura de trabalho ou dos colegas de trabalho, os outros plaqueiros na rua. Durante essas interrupções eram realizadas observações sobre essas interações. As entrevistas com os plaqueiros se concentraram no mês de janeiro de 2009, como se pode notar na tabela que descreve esse conjunto de entrevistas:

Quadro 2.11. Entrevistas com plaqueiros (Janeiro/2009)

\begin{tabular}{|l|l|l|l|l|l|}
\hline Nome & Idade aprox. & Abordagem & Realização & Data da entrev. & Entrevistas \\
\hline Fernando & 60 & Rua & $\begin{array}{l}\text { Rua } \\
\text { Lanchonete }\end{array}$ & $\begin{array}{l}07 / 01 / 09 \\
09 / 01 / 09\end{array}$ & 2 \\
\hline Vladimir & 50 & Rua & Rua & $15 / 0109$ & 1 \\
\hline João & 60 & Rua & Rua & $07 / 01 / 09$ & 1 \\
\hline Josivaldo & 50 & Rua & Rua & $07 / 01 / 09$ & 1 \\
\hline Antônio & 50 & Rua & Rua & $07 / 01 / 09$ & 1 \\
\hline Jorge & 40 & Rua & Rua & $\begin{array}{l}09 / 01 / 09 \\
15 / 01 / 09\end{array}$ & 2 \\
\hline Raimundo & 50 & & & $15 / 01 / 09$ & 1 \\
\hline
\end{tabular}

Fonte: Levantamento de campo, 2009.

Após observação prévia na rua, buscou-se entrevistar plaqueiros que se distinguissem por suas práticas, condutas, interações diferentes e formas diferenciadas de apropriação do espaço.

A principal dificuldade encontrada na realização desse grupo de entrevistas foi conduzi-las, não somente no meio da rua, mas exatamente no centro do calçadão, onde é mais intenso o movimento e a circulação de plaqueiros e demandantes. Quando realizadas ao longo da atividade de trabalho dos informantes, essas entrevistas tiveram lugar nas partes mais movimentadas da rua, que são aquelas ocupadas pelos plaqueiros, em meio a outras pessoas e a muito barulho. Ao invés de tentar contornar esse problema, tentou-se tirar proveito dessa condição, tentando uma observação mais próxima possível da dinâmica de atuação desses personagens.

\subsubsection{Demandantes de trabalho}

No que diz respeito aos demandantes de trabalho, que formam o conjunto mais numeroso de entrevistas, buscou-se uma conversa direcionada por questões que tentassem captar, além das 
questões gerais apresentadas no roteiro básico antes apresentado, também impressões e relatos sobre: i) a procura de trabalho naquele espaço específico, ii) motivos para buscar trabalho ali, iii) as formas de obtenção de informações sobre trabalho, iv) as dificuldades no processo de procura e maiores barreiras à obtenção de um posto, v) o que eles acreditam que se espera de um bom demandante de trabalho e o que fazer para conseguir esses atributos e comportamentos, vi) as expectativas desenvolvidas em torno da procura e vii) os significados sociais e subjetivos envolvidos na procura de trabalho. Nas entrevistas com os demandantes foi feito o esforço de estimular discursos sobre a experiência da procura de trabalho, seus significados, sentimentos, dificuldades e expectativas. Partiu-se do pressuposto de que, por se encontrarem em pleno curso da atividade de procura, vivendo esses sentimentos e elaborando subjetivamente sobre seus significados, discursos sobre esses temas poderiam ser produzidos com maior espontaneidade e naturalidade. Somadas essas questões às do roteiro básico, os demandantes foram entrevistados a partir do seguinte roteiro:

\section{Quadro 2.12. Roteiro de entrevista aplicado aos demandantes de trabalho}

1)Nome, Idade, escolaridade, profissão, desempregado ou empregado, qual tipo de vaga procura.

2)Conte um pouco sobre como tem sido a experiência de procura de trabalho.

3)Como tomou conhecimento desse lugar? Por que procurar trabalho aqui? Quantas vezes veio procurar nesse local?

4)De que bairro vem? Como faz pra chegar até aqui? Quanto tempo demora?

5)Como é o processo de procura naquele local? Descreva um pouco do processo de procura aqui, quais lugares vai, o que faz

6)Como é a interação com os plaqueiros? E com os funcionários das agências?

7)Utiliza algum serviço oferecido aqui como produção de currículo, xerox, internet, cursos, financiamentos?

8)O que faz depois de distribuir os currículos?Volta para casa? Faz alguma coisa no Centro?

9)Procura trabalho em outros lugares da cidade? Onde? Procura trabalho de outras formas? Quais?Sai para procurar trabalho com qual frequiência?

10)Onde ou com quem consegue dicas ou informações sobre procura de trabalho (aonde ir, o que colocar no currículo, que roupa usar, o que falar numa entrevista)? Quais as dicas/informações recebeu?

11)O que imagina que se espera de um bom candidato?

12)Dificuldades que está enfrentando na procura? Como tenta supera-las?

Fonte: Levantamento de campo, 2009.

Foram entrevistados, a partir desse roteiro, 24 demandantes entre dezembro de 2008 e fevereiro de 2009. Os demandantes foram abordados em diferentes momentos de seu processo de procura: aguardando na fila de alguma agência ou edifício, olhando algum plaqueiro ou anúncio na rua, saindo de alguma agência ou estabelecimento que oferece serviços conexos à procura. A grande maioria foi abordada na rua; alguns, no entanto, foram abordados dentro dos edifícios e galerias. Via 
de regra, os demandantes foram entrevistados no mesmo lugar em que foram abordados, seja na rua ou nos edifícios, inclusive por preferência deles, pois eu sempre indagava se eles gostariam de se dirigir para alguma lanchonete ou local mais calmo. Apenas três preferiram se deslocar do local da abordagem para uma lanchonete ou para o interior daquela única galeria que possui alguns banquinhos. A maioria das entrevistas transcorreu na rua de forma que entrevistado e pesquisadora estavam de pé, um na frente do outro. Entretanto, e diferentemente das entrevistas com os plaqueiros, para a realização dessas entrevistas com demandantes, era possível buscar partes menos movimentadas e barulhentas da rua. Para que isso ocorresse, eu simplesmente sugeria que nos dirigíssemos para as laterais do calçadão ou para as pontas da rua, evitando o centro do calçadão e o meio dos quarteirões. Apesar do aparente desconforto colocado pela opção das entrevistas na rua, os informantes que concederam as entrevistas falaram de forma confortável sobre as questões propostas. As entrevistas realizadas na rua tiveram duração variável entre 20 e 60 minutos. Nenhuma entrevista foi realizada em duas partes. Nos casos em que amigos, ou mãe e filho procuravam trabalho juntos, as entrevistas foram realizadas na presença física do companheiro do entrevistado, mas de forma separada. As perguntas foram direcionadas a um informante de cada vez, embora com algumas participações do acompanhante. As entrevistas com esse grupo de informantes se realizaram tal como mostra a tabela abaixo:

Quadro2.13. Entrevistas com demandantes de trabalho (dezembro/2008-fevereiro/2009)

\begin{tabular}{|l|l|l|l|l|}
\hline Nome & Idade & Abordagem & Realização & Data \\
\hline Juliana & 17 & Fila na rua & Fila na rua & $03 / 02 / 09$ \\
\hline Mara & 37 & Rua & Rua & $18 / 12 / 08$ \\
\hline Darcio & 16 & Rua & Rua & $28 / 01 / 09$ \\
\hline Elisa & 18 & Rua & Rua & $28 / 01 / 09$ \\
\hline Ana Maria & 19 & Manufatura de CV & Rua & $29 / 01 / 09$ \\
\hline Juliano & 19 & Rua & Rua & $18 / 12 / 08$ \\
\hline Wellington & 19 & Rua & Rua & $18 / 12 / 08$ \\
\hline Rogério & 19 & Fila na rua & Fila na rua & $03 / 02 / 09$ \\
\hline Fabiana & 17 & Fila na rua & Fila na rua & $03 / 02 / 09$ \\
\hline Sandro & 20 & Lan house & Rua & $18 / 12 / 08$ \\
\hline Adriano & 19 & Rua & Rua & $18 / 12 / 08$ \\
\hline Thiago & 19 & Rua & Galeria Nova Barão & $19 / 12 / 08$ \\
\hline Edson & 23 & Rua & Rua & $28 / 01 / 09$ \\
\hline Walter & 29 & Rua & Rua & $29 / 01 / 09$ \\
\hline Ângela & 22 & Rua & Rua & $18 / 12 / 08$ \\
\hline Silvana & 23 & Rua & Galeria Nova Barão & $19 / 12 / 08$ \\
\hline Ana Paula & 26 & Rua & Ruachonete & $09 / 02 / 09$ \\
\hline Marcelo & 24 & Rua & $09 / 02 / 09$ \\
\hline Silmara & 30 & Corredor de edifício & Escada de edifício & $03 / 02 / 09$ \\
\hline Carlão & 25 & Corredor de edifício & Rua & $28 / 01 / 09$ \\
\hline
\end{tabular}




\begin{tabular}{|l|l|l|l|l|}
\hline Vera & 37 & Corredor de edifício & Corredor de edifício & $03 / 02 / 09$ \\
\hline Armando & 43 & Rua & Rua & $03 / 02 / 09$ \\
\hline Carmem & 50 & Rua & Rua & $29 / 01 / 09$ \\
\hline Miro & 48 & Rua & Rua & $28 / 01 / 09$ \\
\hline
\end{tabular}

Fonte: Levantamento de campo, 2009.

A principal dificuldade para a realização desse grupo de entrevistas foi o grande número de recusas dos demandantes sob a alegação de que estavam ocupados procurando trabalho; nesses casos, com a sugestão de que a entrevista se realizasse ao fim do processo de procura, as recusas permaneciam. Apesar de constituir o grupo mais numeroso de entrevistas, foi também aquele que apresentou maior dificuldade na abordagem e no convencimento dos informantes. Tais recusas, que são legítimas e compreensíveis, parecem estar associadas não apenas à falta de disponibilidade dos demandantes, mas também a características intrínsecas àquela situação e daquele espaço. Essas questões serão abordadas no item seguinte que tenta expor e problematizar as condições em que as entrevistas foram realizadas, qual o impacto dessas condições na produção dos discursos e nas interações entre entrevistados e entrevistadora.

\subsection{A "situação de pesquisa" na situação de procura}

A situação de pesquisa é, ela mesma, determinada, em grande medida, pelas características da própria situação social na qual se insere e que se pretende investigar. Ora, se o próprio local e sua dinâmica estimulam ou constrangem comportamentos e discursos, eles também afetam a dinâmica da pesquisa. Tentou-se, assim, minimizar efeitos de possíveis desconfortos; sendo este um fator inerente ao processo de pesquisa empírica, tentar contorná-los foi fundamental. Entretanto, deve-se ter em mente que eles se constituem também em elementos de análise, pois interferem na inserção do pesquisador no campo e na dinâmica das entrevistas, tanto quanto na qualidade e na natureza da informação; como diz Peirano referindo-se à pesquisa etnográfica:

\footnotetext{
"Na antropologia a pesquisa depende, entre outras coisas, da biografia do pesquisador, das opções teóricas da disciplina em determinado momento, do contexto histórico mais amplo e, não menos, das imprevisíveis situações que configuram o dia-a-dia da pesquisa, entre pesquisador e pesquisados." (Peirano, 1992, pp. 13)
}

A situação social investigada empiricamente é, ela própria, muito específica e colocou para a pesquisa, e para a pesquisadora, desafios também muito próprios. A escolha do tipo de abordagem e a natureza dos instrumentos de coleta de informação foram bastante influenciados pela dinâmica do lugar e da situação. Por exemplo, a abordagem dos informantes na rua, e, principalmente, numa das 
ruas mais movimentadas do Centro de São Paulo, colocou uma série de dificuldades. Embora contornadas, de uma forma ou de outra, elas são parte intrínseca do processo de construção da investigação, à medida que são condicionantes diretos do curso da interação do pesquisador com o informante.

Como relatado, no momento da abordagem, interpelava o informante sobre a possibilidade de uma conversa sobre a dinâmica daquele lugar ou sobre a procura de trabalho, ressaltando seu aspecto informal e enfatizando o termo "conversa" após perceber o incômodo das pessoas com a abordagem na rua e com a palavra "pesquisa". Isso, provavelmente por algumas razões. Primeiro, porque aquele é um espaço apropriado também por pesquisadores de empresas de pesquisa de mercado que aplicam questionários sobre os mais diversos produtos e que, em grande número e espalhados pelo curso da rua, abordam as pessoas, às vezes de forma bastante incisiva, para não dizer agressiva. As pessoas tendem a fugir deste tipo de proposta. Acredito que a palavra "pesquisa", quando proferida naquele lugar, seja rapidamente associada a esse tipo de abordagem. Segundo, porque, devido às mudanças impostas pelo poder público (Prefeitura da Cidade) através das determinações do "Projeto Cidade Limpa" e de algumas ações da Subprefeitura da Sé, aquele espaço vivia, quando do levantamento de dados, um momento de grande tensão e conflito, o que provocava desconfiança e medo nos personagens que tradicionalmente ocupam a rua e que passaram a se sentir ameaçados pelas novas regulamentações.

Mesmo tentando minimizar os efeitos negativos que a idéia de pesquisa pode trazer através da ênfase na noção de "conversa" e no esclarecimento da ausência de relação com o poder público, é, mesmo assim, sensível que aquele é um espaço que produz nas pessoas um comportamento defensivo, que pode dificultar a conversação. Acredito que isso se dê por várias razões. Primeiramente porque, apesar da concentração de pessoas mobilizadas em torno da oferta ou procura de serviços relacionados ao desemprego e procura de trabalho, aquele é um local de intenso trânsito, tendo sido projetado para facilitar a circulação, no qual não existe sequer espaço para sentar, encostar ou descansar. É difícil ficar ali, fixar-se, mesmo se apenas por alguns instantes; somos instados ao movimento, dado o modo pelo qual o espaço se organiza e é apropriado. Além disso, aquele é um espaço muito público, onde as pessoas estão demasiadamente expostas e um grau de proteção da própria pessoa e de distanciamento em relação às outras pessoas se torna necessário. As freqüentes, incisivas (e, como dito antes, às vezes até agressivas) abordagens por parte de panfleteiros, vendedores, promotores de financiadoras, aplicadores de questionários entre outros, podem assustar ou incomodar aquele que não esteja acostumado a essa dinâmica, própria da 
região central da cidade. Um outro elemento que pode produzir esse tipo de conduta reativa é o medo da violência urbana, principalmente dos assaltos tão típicos e freqüentes no Centro. Ademais, aquele é um espaço em que os estímulos visuais, auditivos e sensoriais são muito intensos, o que torna até "natural" que todos se encontrem em um certo "estado de alerta" ou numa atitude de reserva. Há que destacar ainda que, para os demandantes de trabalho, falar sobre sua possível situação de desemprego pode ser, e muitas vezes é, constrangedor; daí a preferência pelo uso da expressão "procura de trabalho" e o descarte da palavra "desemprego". Resumindo, todo esse conjunto de condições adversas à entrevista realizada na rua pode constranger discursos mais longos e elaborados. Isso se comprova pela comparação do tempo de duração das entrevistas realizadas na rua e no interior das agências e estabelecimentos comerciais. Essas últimas foram muito mais longas e exigiram menos trabalho de convencimento na hora da abordagem, tanto porque as condições eram mais confortáveis, quanto porque em seus locais de trabalho esses funcionários não se encontravam em "estado de alerta" ou "atitude de reserva". Isso porque aquele é o ambiente deles, o qual eles dominam e a entrevistadora, essa sim, representava um elemento externo à ele.

Porém, além dessa aparente desvantagem da estratégia de realizar entrevista com alguns atores na rua, há uma vantagem notável na captura de discurso sobre a procura de trabalho no próprio espaço de procura de trabalho. Ali, as sensações sobre essa experiência e as representações sociais mobilizadas no desempenho dessa atividade estão muito afloradas e produzem, às vezes até espontaneamente, depoimentos muito ricos. Essa hipótese, que se constituiu em uma das principais razões para a realização da pesquisa na própria situação de procura, se comprovou e representou uma grande vantagem dessa estratégia metodológica. Ainda que os relatos não fossem muito longos, eles acabavam caindo quase naturalmente em temas e assuntos pertinentes à investigação e produziam discursos sobre questões que, em outros momentos, seriam difíceis de ser abordadas. As entrevistas não eram longas, mas eram certeiras no tipo de discurso que se pretendia estimular. Ou seja, falar sobre uma experiência no exato momento em que ela está sendo vivida produz um efeito positivo na produção do discurso e na condução da entrevista. Isso foi válido, por exemplo, para as entrevistas realizadas com os plaqueiros durante suas atividades de trabalho, onde o que se explorava era justamente o conjunto de características e práticas referentes à atividade de trabalho. Nessas condições falar sobre o que se propunha era muito fácil.

Porém, essa vantagem foi especialmente importante e positiva para o caso das entrevistas com os demandantes de trabalho. Foi possível captar, mesmo em condições adversas e em entrevistas 
curtas, muitos discursos sobre a experiência subjetiva da procura de trabalho. Sentimentos como insegurança, medo, frustração, dúvida e vergonha, eram expressos sem a necessidade de tantos estímulos, pois estavam aflorados. O que seria difícil estimular em outras circunstâncias, como numa entrevista domiciliar, por exemplo, era mais facilmente relatado naquela situação. Essa característica das entrevistas colhidas in loco, ou seja, durante a atividade de procura, possibilitou a análise de elementos dificilmente aprendidos em outras condições e permitiu a investigação de interessantes questões referentes à experiência da procura de trabalho.

Apresentadas as bases do processo de construção teórico-metodológica do presente estudo e descrito o processo de construção prática da pesquisa de campo, estamos agora em condições de passar a descrição detalhada e análise da situação de procura de trabalho, abordando-a sob o prisma das diretrizes teóricas que nos serviram de inspiração. 


\section{CAPÍTULO 3}

\section{A situação de procura: espaço, instituições, atores, interações e condutas}

Partindo das discussões, noções e conceitos apresentados anteriormente, esse capítulo pretende mapear o espaço, as instituições, os atores sociais, as interações e as condutas que têm lugar na situação de procura de trabalho que foi investigada, de modo a evidenciar as características do processo de procura, destacando os elementos micro-sociológicos da vivência de tal situação Espaço, instituições, atores, interações e condutas são elementos que só têm sentido analítico quando tomadas em conta as articulações que mantêm entre si. Dessa articulação é que resulta a situação social, daí porque é impossível analisar um elemento sem remissão aos demais. Embora, por facilidade expositiva, eles venham a aparecer, em seguida, apresentados em tópicos diferentes, ver-se-á que o tratamento de cada um remeterá invariavelmente à sua articulação com outros.

Iniciaremos propondo a idéia de "território de procura de trabalho", construção conceitual que pretende dar conta do modo como se articula espaço físico e apropriações sociais do espaço referidas à situação de procura de trabalho. Com base nessa noção, o espaço estudado será apresentado ressaltando suas dimensões e os processos espaciais requeridos para a descrição de suas características físicas e de sua dinâmica. A forma como os atores sociais se distribuem no espaço e os usos que dele fazem também são parte desse tópico, conquanto venham a ser retomados na descrição detalhada da atuação de cada um desses atores, a ser feita em itens separados.

Apresentados o espaço e a dinâmica da situação de procura em linhas gerais, parte-se para a análise do próprio processo de busca de trabalho e dos elementos micro-sociológicos que o compõem. Para tanto, faz-se uma descrição das instituições e dos grupos de atores sociais que atuam naquela situação de procura, buscando apresentar suas práticas, interações e condutas sociais. Essas instituições e atores foram escolhidos levando em conta sua relevância para a dinâmica da situação de procura de trabalho; assim, na apresentação de cada um deles, é possível observar a apropriação que fazem do espaço, assim como as interações que estabelecem com os demais atores.

As instituições sociais ali presentes (instituições comerciais) foram analisadas através de suas características, mas principalmente, serão abordadas como núcleos concentradores de tipos específicos de atores, centrais à situação investigada. Importam aqui as características dessas instituições, pois elas influenciam a dinâmica de interação entre os atores e a construção de condutas sociais específicas. Com efeito, para entender essa dinâmica, é preciso entender de onde os atores 
falam, ou seja, a partir de quais instituições ou grupos sociais eles concebem a realidade que vivem, trazendo códigos cognitivos específicos, que se expressam quando interagem.

No que se refere aos atores propriamente ditos, importa reter as características de sua atuação e de sua interação com os demais, ressaltando suas práticas e condutas sociais. Importam também as técnicas empregadas na construção das interações tais como a manipulação de informações, as negociações, os consensos operacionais, as cooperações; mas também importam os conflitos, os desequilíbrios e constrangimentos, os quais também são parte das interações reais. A descrição e análise das instituições e dos atores sociais serão baseadas nas pistas deixadas pela literatura, em material documental recolhido, em pesquisas pela internet, e, sobretudo no trabalho de campo, composto por observações, relatos e entrevistas.

Finalizando o capítulo, há uma tentativa de sistematizar os elos entre os vários elementos constitutivos da situação de procura, explicitando sua dinâmica interna e as características que a fazem peculiar. Concomitantemente se tentará indicar alguns dos possíveis elos que aquela realidade de natureza micro-sociológica estabelece com situações sociais distintas, com fenômenos de natureza macro-sociológica e com outras dimensões da vida social dos demandantes de trabalho.

\section{A procura de trabalho numa perspectiva sócio-espacial: cidade, espaço e territórios}

Uma situação social é sempre constituída pelo espaço e pelos elementos físicos que a compõem. A situação de procura de trabalho escolhida como objeto empírico dessa pesquisa está, como toda situação social, nitidamente pautada pelo espaço urbano em que se circunscreve. Não sem razão: o tipo de procura de trabalho que escolhemos estudar se define por uma particularidade, a de ser territorializada; basta compará-la, por exemplo, com a procura via internet, a procura virtual, na qual, tanto o sentido de espaço, quanto a natureza da relação social estabelecida no exercício do serviço de intermediação de oportunidades são radicalmente distintas daquela que se expressa através da procura em agência de emprego. Sendo assim, assumimos, como ponto de partida, que a cidade e a rua estão longe de ser, do ponto de vista analítico, meros panos de fundo

para o delineamento da situação de procura que está em pauta. Daí porque é impossível prosseguir numa descrição detalhada sem antes situá-la numa (mesmo que breve) discussão sobre cidade, espaço e território, de modo a introduzir a problemática sócio-espacial na qual a investigação se insere. 
O espaço, numa perspectiva sócio-antropológica, significa muito mais que um conjunto de dispositivos físicos. O espaço urbano, por sua vez, é, nessa mesma perspectiva, um elemento complexo, o qual não pode ser simplesmente delimitado por barreiras ou características físicas. Nessa mesma linha, sugere Magnani (1996) que, na metrópole, as unidades significativas para observação e análise não são dadas de antemão, pois:

“...é necessário destacá-las do fundo impreciso da realidade tal como é vista pelo senso comum. As descontinuidades significativas do tecido urbano não são o resultado de fatores naturais, como a topografia, ou de intervenções como o traçado de ruas, zoneamento e outras normas. Tais descontinuidades são produzidas por diferentes formas de uso e apropriação do espaço.” (Magnani, 1996, pp. 38)

Mas, para além do desafio da delimitação dos espaços, há sempre o desafio da apreensão da articulação entre as dimensões espacial e social e esse esforço pode ser feito a partir de mais de uma perspectiva teórica. O olhar sócio-antropológico sobre a cidade contemporânea implica uma tentativa de superação de pressupostos e metodologias da antropologia e da sociologia clássicas, pois, os espaços urbanos hoje não são necessariamente expressão de identidades fortemente enraizadas e claramente definidas; não se pode mais pensar em espaços apenas nos termos de "pertencimento".

Para Zukin (2000), há uma dissolução das identidades espaciais tradicionais e uma reconstituição dessas sob novas bases ${ }^{31}$, mas o espaço urbano seria um instrumento analítico importante para construir uma ponte de convergência entre biografia individual e mudança estrutural. (Zukin, 2000, pp. 84). A experiência urbana contemporânea propiciaria a formação de uma complexa arquitetura de territorialidades múltiplas e flexíveis. Essa, não formaria um mosaico harmonioso, mas criaria uma dinâmica complexa de sobreposição de espaços e zonas simbólicas. Nessa perspectiva, defendida por Arantes (2000), importam também as ruas e as praças: as paisagens de passagem. A situação de procura estudada é aqui vista pela perspectiva das territorialidades, pois não se configura como um "espaço de pertencimento". Essa abordagem baseada na multiplicidade, na sobreposição e na flexibilidade dos espaços é utilizada para pensar o espaço no qual se dá a situação de procura estudada, isso porque aquela é também uma paisagem de passagem. Ela é realmente um espaço de trânsito intenso de pedestres, que não cria identidades enraizadas, mas performances temporalmente marcadas e situadas, como no caso das pessoas à procura de trabalho. Além disso, desenvolvem-se naquele mesmo contexto diversas atividades distintas da procura de trabalho, as quais configurariam outras situações sociais caracterizadas por

\footnotetext{
${ }^{31}$ Para a autora esses processos de reconstituição das identidades espaciais nas cidades pós-modernas estão fortemente associados ao consumo e às novas formas de apropriação cultural.
} 
outros usos e apropriações do espaço. Nesse sentido, existe ali uma sobreposição de espaços e de zonas simbólicas.

Convergindo de forma muito interessante com a forma interacionista de pensar o espaço na constituição da situação social, nessa abordagem sócio-antropológico aqui utilizada, também está explícita a idéia básica de há uma relação de interdependência entre as dimensões social e espacial. Grosso modo, não há exterioridade do espaço e da paisagem urbana em relação às práticas sociais.

“.Importam as práticas por meio das quais as estruturas físicas são balizas de territorialidades, ainda que efêmeras, em marcos de lugar ou de vida social re-singularizada. É fundamental saber de que modo estes constructos identificadores, que ocupam posição de destaque na paisagem e no mercado de bens materiais e simbólicos, participam efetivamente dos processos sociais." (Arantes, 2000, pp. 12-13.)

Parte-se também da hipótese de que um espaço, mesmo que constituído de regras implícitas e fronteiras pouco definidas, ao modo de Strauss, pode permitir a construção de um conjunto de práticas e condutas sociais específicas, configurando uma situação socialmente densa e impregnada de significado. O território da procura de trabalho é constituído por barreiras e delimitações pouco definidas, assim como por regras muitas vezes implícitas; porém, ele comporta e condiciona a situação de procura de trabalho, como veremos a seguir.

Partimos desses pressupostos e, assim como Telles, acreditamos que, também para essa pesquisa:

"É preciso que se diga que estamos trabalhando com uma noção de território que se distancia das noções mais correntes associadas às comunidades de referência. (...) Feitos de práticas e conexões que articulam espaços diversos e dimensões variadas da cidade, os territórios não têm fronteiras fixas e desenham diagramas muito diferenciados de relações conforme as regiões da cidade e os tempos sociais cifrados em seus espaços." (Telles, 2006, pp. 71, 72)

O que se pretende enfatizar na noção de espaço utilizada é, assim, o modo pelo qual se constrói o alinhamento de condutas numa situação concreta, mais ou menos definida espacialmente. Novamente com Telles, assume-se, então, que os espaços são circuitos que, por sua densidade, permitem desvendar "a natureza de [suas] vinculações, mediações e agenciamentos da vida cotidiana que operam como condensação de práticas e relações diversas” (Telles, 2006, pp. 72). Para a presente pesquisa entende-se que o território é, nesse sentido, expressão da dimensão das práticas, conexões e agenciamentos da vida cotidiana; das disposições cognitivas e comportamentais pelas quais os atores definem uma experiência social e dela participam. Assim:

"O que transforma uma área física ou sensível em entidade sociologicamente pertinente são as regras que permitem controlar a ordem dos lugares e a comunicação entre os participantes ratificados, transeuntes, espectadores obrigatórios ou 'não-indivíduos'. (...) Não a rua dos movimentos sociais, mas a rua que cotidianamente dá ensejo a ajuntamentos e, com esses ajuntamentos, a testes normativos sobre o próprio e o impróprio, o conveniente e o tolerável em nossas sociedades.” (Joseph, 2000, pp. 56-57) 
Importa extrair dessas abordagens para a análise da situação estudada a busca dos usos e apropriações que se faz do espaço, e não só a descrição da sua dimensão física e das suas delimitações concretas. O conjunto de usos e apropriações do espaço investigado ligados à atividade de procura de trabalho é aqui denominado "território de procura de trabalho". A caracterização desse território não se faz por sua configuração física concreta, mas pela forma como é apropriado pelos atores e instituições envolvidos na procura; mas e ao mesmo tempo, pela forma como condiciona a atuação desses atores, o que converge com a forma como o espaço é analiticamente problematizado por Strauss (1979). A relação daquela situação social com o espaço em que se desenvolve é vista, dentro da dinâmica mais ampla da cidade, a partir da perspectiva das territorialidades, pois ali se desenvolvem outras situações sociais territorializadas e simbolicamente diferenciadas, havendo, portanto, uma sobreposição de territórios. Porém, não importam, para essa investigação, todas as características físicas e todos os usos que se faz daquele espaço, mas os usos e apropriações relacionados à procura de trabalho, alvo desse estudo, que constituem simbolicamente o "território da procura de trabalho". Essa noção de território é utilizada aqui, pois, acredita-se que, ela possibilita articular espaço, interações e condutas, além de situar aquela situação numa dinâmica urbana mais ampla.

Reconhecido hoje como um espaço de procura de trabalho, a Rua Barão de Itapetininga era, em torno da década de 1950, conhecida como "a artéria que vale milhões" (Marques, 1966, pp. 263) 32. A região caracterizava-se à época por suas galerias sofisticadas e inovadoras, do ponto de vista arquitetônico, tais como a Galeria Califórnia e a Galeria Nova Barão, que completavam o cenário de modernidade e o espaço de lazer $^{33}$ e comércio da elite ${ }^{34}$. Esse poder econômico e simbólico do Centro Novo e, mais especificamente, da Rua Barão de Itapetininga atingem seu auge na década de 1960. Há, a partir de 1970, um novo processo de apropriação espacial e um movimento de declínio no prestígio da área, que geraram um gradual processo de esvaziamento e desvalorização imobiliária da região. Tal movimento pode ser atribuído à criação de novas centralidades na cidade. Conforme Frúgoli (2000), ao longo do século XX, a cidade de São Paulo teria passado por um processo

\footnotetext{
${ }^{32}$ Para mais detalhes sobre a história mais longínqua da rua e do Centro da cidade ver: Alonso, 1991 e Americano, 1957. Para mais detalhes sobre a construção do Viaduto do Chá ver: Americano, 1957, pp. 123-128 e Guimarães, 2005 , pp. 201-203. Para mais detalhes a construção do Teatro Municipal e seu impacto no Centro de São Paulo e na cultura paulistana ver: Luz, 1999, 61-72 e Americano, 1957, pp.328-330.

${ }^{33} \mathrm{O}$ entorno da Rua Barão de Itapetininga ficou famoso pelos cinemas, muito modernos para a época; a região era chamada de Cinelândia. Para mais detalhes ver: Guimarães, 2005. Além disso, se estabelece ali também a famosa Confeitaria Fasano. Importantes nomes do Modernismo como Mário e Oswald de Andrade eram freqüentadores da região.

${ }^{34}$ Sobre a história do comércio paulistano ver Deaecto, 2002 e Malin, 1995.
} 
contínuo de criação e recriação de centralidades. Isso se deu através da constituição de locais urbanos voltados para a apropriação e para o consumo das camadas economicamente mais altas, seguidos de posterior abandono dessas áreas, que se tornam degradadas e são, na seqüência, reapropriadas pelas camadas mais populares. Esse processo teria se dado paralelamente à disseminação das periferias. O Centro de São Paulo configurou uma centralidade que perdeu seu lugar para a região da Avenida Paulista e essa, por sua vez, estaria perdendo seu lugar para a região da Avenida Engenheiro Luís Carlos Berrini. Há que se citar também o surgimento de novas formas de estabelecimento comercial, os shoppings centers, que tiraram a importância e o glamour das galerias e transformaram os modos de consumo, de sociabilidade e a dinâmica da cidade (Frúgoli., 1992; 2000).

Voltado para explicar esse movimento de transformação do Centro há também outro tipo de repertório, calcado no discurso que atribui as novas formas de apropriação social do mesmo às medidas de intervenção urbana que, a partir de 1970, construíram as vias para pedestres, ruas com acesso proibido aos automóveis. Esses calçadões, inspirados nos bulevares europeus, teriam o objetivo de "embelezar" o Centro e facilitar o trânsito de pedestres. Porém, o argumento defendido por alguns arquitetos, urbanistas e alguns atores fundamentais do processo de gentrification do Centro paulistano, como a ONG "Viva o Centro", é o de que os calçadões teriam facilitado a apropriação do espaço pelo comércio informal, por atividades ilegais e pela violência urbana, afastando os estabelecimentos comerciais de luxo e as grandes empresas ${ }^{35}$.

Desde a década de 1970, quando a Rua Barão de Itapetininga se transformou num largo calçadão, esse espaço foi marcado pela intensa circulação de pedestres ${ }^{36}$, como seria de se esperar, mas foi e tem sido também apropriado por personagens diversos. São vendedores ambulantes, artistas de rua, pregadores religiosos, e hoje em dia, principalmente, panfleteiros e plaqueiros. Esses dois últimos dedicam-se crescentemente a veicular anúncios de agências de emprego e dos demais serviços conexos à procura de trabalho. Sobreviveram os edifícios antigos, a arquitetura art decó, as galerias cada vez mais esvaziadas e alguns poucos estabelecimentos comerciais antigos. Neles, muitos já deteriorados ou esvaziados, predominam escritórios, consultórios e serviços, tal como notamos nas observações de campo e como havia sido destacado pela literatura desde há muito

\footnotetext{
${ }^{35} \mathrm{O}$ discurso que culpa a "pedestrianização" do Centro pela degradação da área é muito característico da ONG "Viva o Centro"- influente ator nos debates que envolvem o Centro de São Paulo- e de intelectuais ligados a ela. Há uma série de iniciativas, principalmente coordenadas ou ligadas a esta ONG de tentar reverter tal processo. Para mais detalhes sobre os calçadões ver: Guimarães, 2005; Anelli, 2005 e Yoshinaga, 2004.

${ }^{36}$ Nas ruas Direita, São Bento, viaduto do Chá, Xavier de Toledo e Barão de Itapetininga, todas no Centro, o volume de pedestres estimado é superior a 6.000 pessoas por hora. (Campos, Nakano, e Rolnik, 2004, pp. 136)
} 
(Frúgoli, 1995). É nesses edifícios e galerias que se localizam hoje, as agências de empregos e os serviços procurados pelas pessoas em busca de trabalho.

Esse processo de transformação iniciado nos anos de 1970, e que culminou na composição desse "território da procura de trabalho", constitui a história recente do lugar e ainda carece de investigação histórica sistemática. Relatos de funcionários das agências de emprego sugerem que o local passou a ser procurado não apenas por seu baixo custo locacional, mas por sua grande facilidade de acesso por meio de transportes públicos; isso porque, no período de constituição desse mercado, a captação de candidatos constituía a grande dificuldade das agências. Por ora, podemos dizer quer esse movimento de concentração de agências de emprego vai ao encontro de uma tendência urbanística geral, no sentido da redefinição funcional dos espaços da cidade. Tal tendência se expressa na crescente especialização de subespaços em redutos comerciais, notadamente nas áreas centrais. Dada a amplitude das metrópoles, torna-se interessante para alguns setores comerciais operarem em conjunto, formando clusters que reúnem firmas e estabelecimentos envolvidos com atividades inter-complementares, num pólo espacial concentrador, o que acaba sendo também vantajoso para os consumidores de um produto ou serviço específico:

\footnotetext{
“Tais concentrações ou 'clusters' atingem trechos ou conjuntos de ruas e ocorrem muitas vezes espontaneamente, a partir de precedentes historicamente localizados ou empreendimentos-âncora (...). A concentração de atividades, por sua vez, cria lugares de referência para fornecedores e consumidores, reforçando a preferência dos comerciantes por aquela localização, que tende a se valorizar e se torna, em última instância, um endereço indispensável..” (Campos, Nakano e Rolnik, 2004, pp. 147)
}

No caso de São Paulo, a Rua Barão de Itapetininga (e seu entorno), no chamado Centro Novo, é um endereço indispensável na rota das pessoas à procura de trabalho.

\section{O "território da procura de trabalho": o lugar e a dinâmica}

A Rua Barão de Itapetininga tem 330 metros de extensão por 20 metros de largura. É um largo calçadão formado por três quarteirões. Conta com aproximadamente 28 edifícios (de 8 a 14 andares), 400 lojas e seis galerias ${ }^{37}$. Ela é cortada por várias transversais: Avenida Ipiranga, Rua Dom José de Barros, Rua Marconi e Conselheiro Crispiniano e acaba na Praça Ramos. As ruas Vinte e Quatro de Maio e Sete de Abril são paralelas à rua Barão de Itapetininga e juntamente com ela e com as transversais citadas formam o que aqui é denominado "território da procura de trabalho”. Em uma ponta da rua estão a Praça Ramos e o Teatro Municipal; na outra ponta estão a

\footnotetext{
37 As galerias com entrada na Rua Barão de Itapetininga são: Galeria Califórnia, Galeria Ita, Galeria Guatapará, Galeria Itapetininga, Galeria Lousan e Galeria Nova Barão. Nas ruas do entorno podemos contar pelo menos mais sete galerias.
} 
Praça da República e a Escola Caetano de Campos. A região é fartamente servida pelo transporte público; não só porque fica localizada entre duas estações de metrô (República e Anhangabaú), mas também por se localizar perto de importantes terminais de ônibus (Praça Ramos, Terminal Parque D. Pedro e Terminal Princesa Isabel) e de algumas das principais avenidas da cidade, como a Avenida Ipiranga, a Avenida Consolação e a Avenida Nove de Julho.

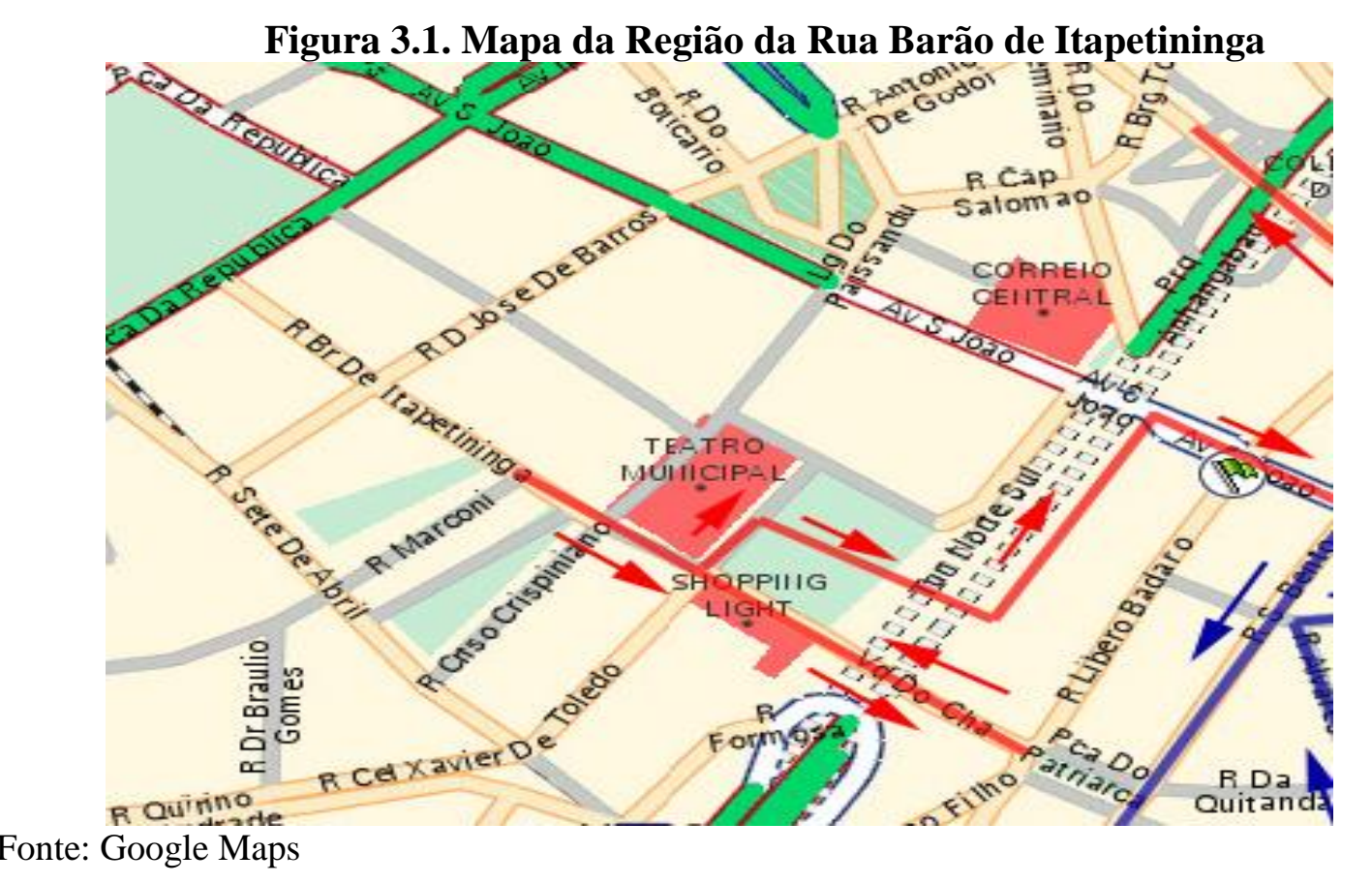

No interior dos prédios e galerias estão estabelecidos hoje, além das agências de emprego e dos serviços conexos à procura, profissionais liberais como advogados, contadores e médicos, principalmente. Na parte térrea dessas edificações funciona um movimentado comércio, o qual é constituído predominantemente por lojas de artigos populares (roupas, calçados, perfumaria, eletrodomésticos), além de agências bancárias, agências de crédito e financiamento, farmácias e lanchonetes. As entradas desses edifícios e galerias se intercalam com as vitrines de lojas e agências bancárias. Existem ainda duas bancas de jornal no meio do calçadão, cerca de dez postes de iluminação e algumas poucas latas de lixo.

As demais ruas desse território da procura, como as transversais e paralelas à Barão possuem um comércio semelhante. Só as ruas Conselheiro Crispiniano e Marconi têm um comércio diferenciado; na primeira especializado em artigos fotográficos (câmeras, lentes, filmes, conserto de aparelhos e recuperação de imagens) e na em lojas de vestuário feminino. Nos calçadões das ruas Dom José de Barros, Marconi e Conselheiro Crispiniano encontramos barracas de vendedores 
ambulantes autorizados pela Prefeitura ${ }^{38}$. Na Rua Barão de Itapetininga elas não existem. Porém, vendedores ambulantes sem autorização da Prefeitura ocupam de forma intermitente todo esse território e sua atuação depende da dinâmica da fiscalização da Subprefeitura. Esses, que são considerados vendedores "ilegais", vendem principalmente CDs, DVDs, mas também eletroeletrônicos, brinquedos, óculos de sol, calçados e roupas e têm sido alvo de intensa repressão durante a gestão do atual Prefeito, Gilberto Kassab. Apesar do intenso movimento, a Rua Barão de Itapetininga e as demais ruas do seu entorno são razoavelmente limpas, o que sugere um trabalho intenso de limpeza urbana. Porém, uma das características daquela localidade é o barulho, provocado por carros e ônibus, que não circulam não pelos calçadões, mas principalmente por plaqueiros, panfleteiros, vendedores de mercadorias e serviços diversos que, assim como numa feira a céu aberto, divulgam aos gritos as informações sobre os seus produtos.

\section{Figura 3.2. Foto da Rua Barão de Itapetininga}

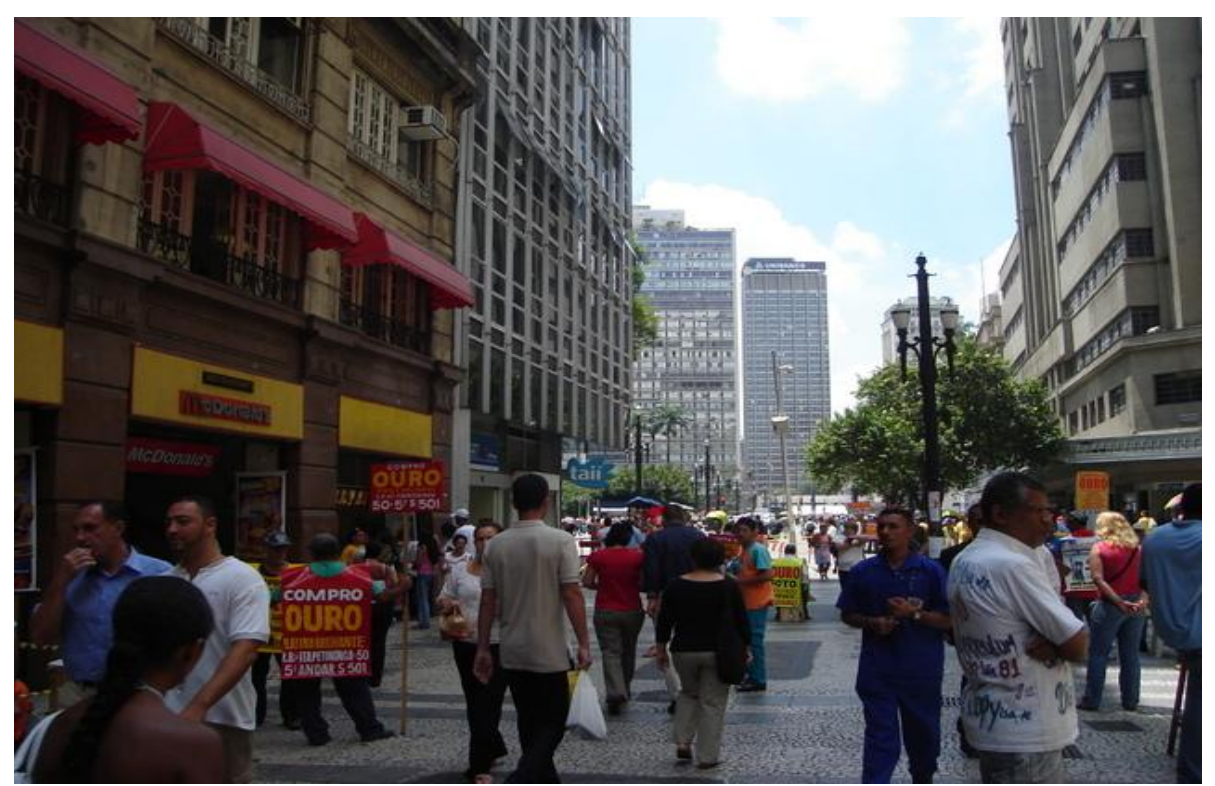

Fonte: Levantamento de campo, 2009.

Inúmeras agências de emprego estão instaladas na Rua Barão de Itapetininga e adjacências: desde a mais importante empresa brasileira do mercado de intermediação de mão-de-obra, a pioneira

\footnotetext{
${ }^{38}$ Esses ambulantes são os que possuem o TPU (Termo de Permissão de Uso) e pagam uma taxa anual para a Prefeitura. Idosos e deficientes têm prioridade na obtenção dessa licença. As barracas dos permissionários são fixas, com local determinado e devem seguir uma série de regras. Essas barracas vendem artigos diversos como artesanato, bijuterias, roupas, bolsas, livros, enfeites, entre outros, mas deve-se comprovar que não são artigos falsificados ou contrabandeados, o que cabe aos fiscais da Subprefeitura fiscalizar.
} 
Gelre $^{39}$, até agências extremamente pequenas ${ }^{40}$. Só na Rua Barão de Itapetininga (em seus edifícios e galerias) existem quase 30 agências de emprego. Se computarmos as agências sediadas nas ruas de seu entorno como as paralelas Vinte e Quatro de Maio e Sete de Abril e as transversais Marconi, Conselheiro Crispiniano e Dom José de Barros, esse número chega a mais de 60 agências ${ }^{41}$. Os prédios e galerias do passado, que hoje sediam as inúmeras agências de emprego, tornam-nas quase invisíveis - não fosse pelo imenso número de panfleteiros e plaqueiros que representam, na rua, a "cara" desses estabelecimentos - e, ao fazê-lo, imprimem uma dinâmica à procura de trabalho que passa não só pela busca de ocupações, mas também pela procura das próprias agências, dando ao personagem do plaqueiro um papel fundamental no funcionamento desse mercado. A estratégia do uso maciço do trabalho de panfleteiros e plaqueiros só é possível porque a Barão é uma via exclusiva de pedestres desde os anos de 1970; por isso, eles podem ali circular sem a interferência de carros.

Esses plaqueiros são responsáveis por divulgar, com anúncios em suas placas, as vagas de emprego oferecidas pelas agências ou serviços propiciados por outros tipos de estabelecimento. Os plaqueiros podem segurar placas ou vestí-las na forma de um colete de plástico flexível no qual são afixadas informações. Eles ficam o dia todo na rua, sentados ou de pé circulando. Alguns plaqueiros simplesmente desfilam suas placas na rua, outros divulgam oralmente (aos gritos) as informações das placas; mas há também os que recolhem currículos e aqueles que fazem até mesmo a triagem desses currículos. Ou seja, a configuração daquele espaço impede a visibilidade dos estabelecimentos, trazendo à cena um personagem que se torna central à dinâmica da situação, não só porque divulga vagas e estabelecimentos, mas porque, como será explorado adiante, pode ser responsável por outras funções fundamentais da operação das agências.

Esse processo de tornar visível, através dos plaqueiros, espaços como os das agências, que são invisíveis àqueles que passam na rua, pode ser considerado um processo espacial de visibilidade, dentre aqueles listados por Strauss (1979). Sem dúvida esse é um dos processos espaciais mais significativos para composição daquela situação social e de toda a dinâmica de procura que ali se desenvolve. O processo de competição pelo uso do espaço, travado entre plaqueiros e panfleteiros e entre esses atores da situação de procura e outros atores exteriores à ela, como desenvolveremos a

\footnotetext{
${ }^{39}$ Ver Pedro (2007)

${ }^{40}$ Ver Georges e Janequine (2007)

${ }^{41}$ Números tirados da edição mais atualizada, ao tempo do trabalho de campo, do "Guia das Agências de Emprego de São Paulo" vendido na própria rua a R \$1,00. Nele constam os nomes das agências e seus endereços. Além das agências daquela região o Guia traz também uma listagem com mais de 220 endereços de agências, organizados por zona da cidade.
} 
seguir, é outro processo espacial determinante daquela dinâmica. Exemplos como estes nos ajudam a ressaltar a articulação entre espaço e situação social.

A dificuldade de visualizar esses estabelecimentos criou também o surgimento de um novo produto nesse mercado de serviços associados ao desemprego e à procura de trabalho: uma lista com os endereços das agências de emprego que é vendida na rua a preços módicos $(\mathrm{R} \$ 1,00)$; frequentemente atualizada, essa lista tem grande saída e é o guia do demandante de trabalho. Igualmente pelo fato de que as agências de emprego se localizam dentro dos prédios, surgiu a necessidade - por parte dos estabelecimentos situados no edifício Rio Branco, aquele com maior concentração de agências - de organizar uma fila de demandantes de trabalho do lado de fora do prédio, na própria rua, para não gerar lotação no interior do mesmo exigir a apresentação de documento de identidade.

Dentre os edifícios que comportam as agências de emprego, o edifício Rio Branco é o mais famoso porque nele operava o maior número delas. Segundo informações de funcionários do edifício ele já chegou a sediar quase vinte agências. Hoje, no entanto, elas não chegam a dez. Porém, esse prédio ainda é bastante conhecido na região porque ali se forma diariamente uma fila de demandantes de trabalho. Essa fila fica disposta na rua e é organizada por um segurança que vai, aos poucos, liberando a entrada daqueles que procuram as agências e possuem documento de identidade em mãos. Nos demais edifícios e galerias a entrada é livre ou se exige apenas a identificação na recepção. Devido à pluralidade de sub-espaços relacionados à situação de procura de trabalho existentes dentro do edifício Rio Branco, no qual funcionam várias agencias de emprego, surgiu a necessidade de criar uma forma organizada de acesso a eles. Esse processo de organização do uso dos espaços desse edifício, que acaba por gerar a fila organizada de demandantes de trabalho na rua, é outro processo espacial que compõe e tipifica aquela situação social, para seguirmos explorando a inspiração de Strauss.

$\mathrm{Na}$ rua, é impressionante o número de informações sobre vagas de trabalho e serviços correlatos à procura que se expressam, das mais diferentes formas: nos corpos dos plaqueiros e nos gritos proferidos por alguns deles; nos papéis de propaganda distribuídos pelos panfleteiros; nos papéis, cartazes e anúncios colados no chão, nas latas de lixo, nas fachadas dos edifícios, nos postes, nas bancas de jornal, nos muros e, nas árvores. Vê-se, assim, que o espaço e todos os seus dispositivos físicos (muros, postes, fachadas e chão) são mobilizados pelos atores como recurso concreto na divulgação de informações e serviços. Além disso, uma prática cada vez mais comum 
naquele espaço é a coleta de currículos por parte dos plaqueiros. A rua pode ser, então, não só espaço de procura de trabalho, mas também, em algum nível, de seleção e recrutamento.

\section{Figura 3.3. Foto de anúncios de trabalho colados nas fachadas do comércio}

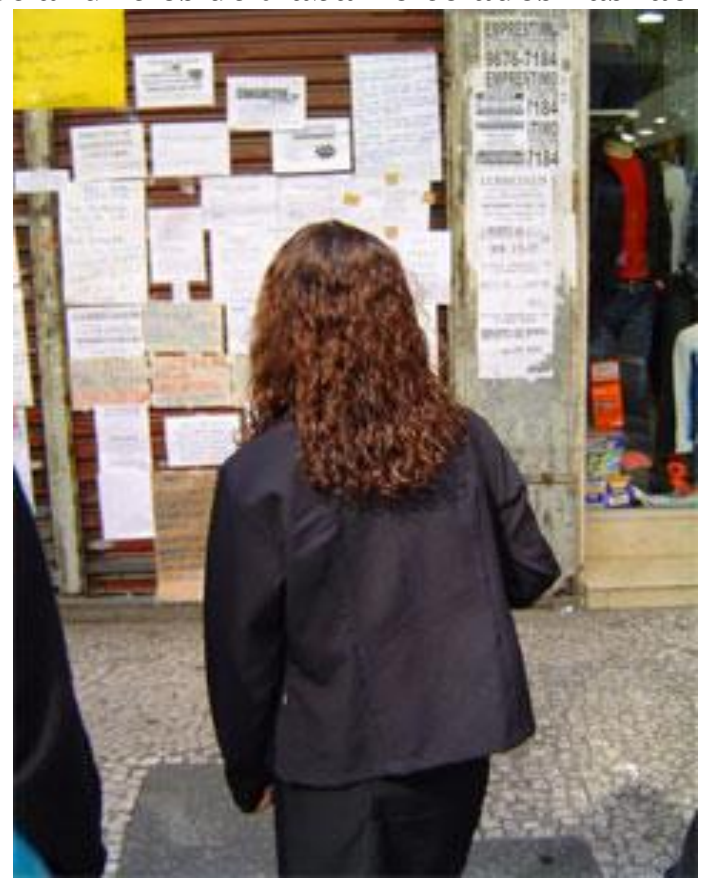

Fonte: Site do Centro de Estudos da Metrópole (www.centrodametropole.org.br/divercidade/numero4)

Esse cenário composto por agências, plaqueiros e informações abundantes sobre oportunidades de trabalho atrai diariamente um número enorme de pessoas, os demandantes de trabalho, sejam eles desempregados ou não. Esses demandantes circulam pelo espaço durante o horário comercial, predominantemente no período matutino e, principalmente, nos primeiros dias da semana; de segunda a quarta o movimento é maior. Vão em busca de trabalho, procurando as agências de emprego ali instaladas e qualquer outro tipo de informação correlata à procura que por ali possa circular, assim como também os serviços conexos à procura de trabalho. Basicamente, os demandantes fazem uma "peregrinação" naquele território, tentando alcançar o maior número possível de agências, maximizando a busca.

Aproveitando esse cenário que atrai as pessoas em busca de trabalho, algumas empresas usuárias de trabalho, vale dizer, empregadoras diretas (mesmo que não localizadas na região) enviam funcionários para captar ali candidatos às suas vagas. Outras firmas têm ali o seu próprio plaqueiro, que faz o mesmo serviço que os plaqueiros das agências, mas que divulgam, sem a intermediação destas, as vagas abertas por uma empresa ou firma específica. Indústrias, redes de 
supermercados e redes de fast-food são alguns exemplos de empresas que recorrem a esse tipo de estratégia, como foi observado durante o trabalho de campo. Outros tipos de empresas, como as agências de promoção de eventos e centrais de telemarketing, setores de atuação em que há muita demanda e muita rotatividade de mão-de-obra, têm adotado a estratégia de estabelecer escritórios ou filiais naquela região, e enviar selecionadores próprios para, na própria rua, dar inicio ao processo de captação de candidatos. Agências de promoção de eventos colocam seus selecionadores na rua com a instrução de abordar as pessoas que se encaixam no perfil de candidato que eles precisam, levando em conta, principalmente idade e a aparência física. Ou seja, há um processo de seleção para determinadas vagas que tem lugar ali mesmo na própria rua e que pode incluir até as pessoas que não estão à procura de trabalho ${ }^{42}$. Assim, prescindindo das instituições de intermediação de mão de obra, algumas firmas se aproveitam do público que essas instituições atraem para realizar diretamente e sem intermediação de outra empresa a captação de mão-de-obra na rua, reforçando o tipo de uso e apropriação daquele espaço e potencializando a imagem de "território de procura de trabalho" do mesmo.

Além das numerosas agências de emprego e das empresas que buscam candidatos sem fazer uso do mercado de intermediação de mão-de-obra, ali atuam também outros personagens envolvidos no mercado que tem o demandante de trabalho como principal cliente. Há uma ampla gama de serviços especializados e dirigidos a esse público. Manufatura e cópia de currículos (ou envio de currículos pela internet), adiantamento do seguro-desemprego, venda de guias com os endereços das agências de emprego (organizadas segundo áreas do centro e mesmo do município), escritórios de advogados trabalhistas, financiadoras de empréstimo, estabelecimentos que ofertam cursos e treinamento profissional, cursos preparatórios para processos de seleção (como se comportar, como se vestir e o que falar em entrevistas e dinâmicas de grupo), cursos preparatórios e venda de apostilas para concursos públicos, exames médicos (para admissão e demissão), grupos de apoio psicológico oferecido aos desempregados (muitas vezes organizados pelas próprias agências ou por ONGs), e grupos de apoio espiritual (organizados por igrejas, que pretendem arrebanhar novos fiéis entre os desempregados que podem se encontrar em situação de instabilidade social e emocional) tudo isso está ao dispor daquele à procura de trabalho.

Parte significativa desses serviços tem a função de transformar pessoas que não têm emprego em "verdadeiros demandantes de trabalho", dotando-os dos instrumentos, recursos, habilidades e

\footnotetext{
${ }^{42} \mathrm{Eu}$ própria, durante minhas observações, fui abordada por um desses selecionadores e recebi a proposta de participar de uma entrevista para seleção de promotoras de venda para a rede uma grande rede de hipermercados.
} 
códigos que deles se espera; outra parte compensa ou suplementa as necessidades materiais ou emocionais postas pela situação de privação de trabalho (Guimarães, 2007-b). Esses estabelecimentos, assim como as agências, não se concentram somente na rua Barão de Itapetininga, podendo sediar-se nas ruas do entorno. Entretanto, tanto seus plaqueiros quanto seus panfleteiros, concentram-se no calçadão da Barão, onde também estão igualmente localizados os seus principais clientes. Esse é um mercado que cresce em número de estabelecimentos e variedade de produtos e será tratado em detalhe a seguir.

Esse mosaico de atividades e de informações atrai diariamente um número de desempregados e demandantes de trabalho, que assusta o observador por sua magnitude, especialmente volumosa às segundas e terças-feiras, notadamente nos períodos da manhã, quando o movimento é surpreendente. É possível dizer, novamente com Strauss, que a freqüência da mobilização deste espaço para a encenação daquela situação social é ditada pelo funcionamento do mercado de intermediação que ali opera, de segunda à sexta, das 8 horas às 17 horas. Porém, em alguns dias da semana e horários do dia, o uso daquele espaço para a procura de trabalho se torna ainda mais intenso. Essa variação na intensidade, é ditada pelos demandantes que acorrem àquele espaço, mais que pelas firmas; ao que voltaremos no curso deste trabalho.

Há uma circulação intensa de pessoas na rua e dentro dos edifícios onde se localizam as agências, além de filas e aglomerações em torno dos plaqueiros com a finalidade de visualizar as informações neles veiculadas. Isso sugere a importância de outras características espaciais que têm impacto na configuração da situação, uma situação de procura de trabalho que poderia ser qualificada como espacialmente dispersa; a pista novamente extraída de Strauss, é particularmente estimulante já que permite olhar "de perto e de dentro" para este cluster; é um aglomerado, se visto de fora, mas espacialmente disperso, quando visto de dentro e com lentes de aproximação; com efeito, suas atividades estão distribuídas por algumas ruas e, além das ruas, outros sub-espaços desse território são utilizados, tais como os espaços internos das agências de emprego e de outros estabelecimentos comerciais conexos à procura. Mas, apesar dessa dispersão, a Rua Barão de Itapetininga, especialmente o quarteirão que fica ao lado da Praça Ramos, é a parte desse território mais intensamente mobilizada na situação de procura, pois é onde se concentra o maior número de atores nela envolvidos. Com isso, sugere-se que há na situação uma hierarquia entre os espaços que coloca esse último descrito como aquele de maior destaque.

As observações permitem perceber que há um grande número de atores que não estão envolvidos nos processos de procura de trabalho, mas que também usam e se apropriam (cada um da 
sua forma) daquele espaço. Personagens que são típicos daquele lugar, vale sublinhar, mas que não participam diretamente das atividades relacionadas à procura de trabalho: vendedores ambulantes os chamados "camelôs" -, mendigos, promotores de crédito, pesquisadores tentando aplicar questionários sobre algum tipo de produto, pregadores religiosos, artistas de rua, consumidores das lojas de artigos populares, fiscais da Subprefeitura, policiais da Guarda Metropolitana e transeuntes apenas de passagem. Muitos se aproveitam da aglomeração de pessoas que aquele espaço lhes põe ao dispor, para mendigar, para oferecer outros serviços, para obter informações estratégicas; outros se aproveitam das próprias condições físicas que estão na base da aglomeração, como a "pedestrianização" da rua, que confere mais tranqüilidade aos deslocamentos daqueles que por ali circulam como meros transeuntes.

Porém, como exposto, o que caracteriza e diferencia um território de outro não são só os seus dispositivos físicos, mas, principalmente, seus usos, práticas e apropriações. Aquele espaço tem mais de um tipo de uso e apropriação, como alertado: i) é uma zona de intensa passagem de transeuntes, pois liga pontos importantes do Centro, ii) é uma região de diversificado comércio popular, iii) possui uma grande concentração de serviços de profissionais liberais, como médicos e advogados e iv) é um território de procura de trabalho. Os usos concretos e simbólicos daquele espaço se sobrepõem, desse modo, o que é consistente com a lógica das territorialidades múltiplas e flexíveis. No mesmo espaço da rua em que se desenvolve a situação de procura de trabalho e atuam os demandantes de trabalho, os plaqueiros e os panfleteiros do mercado de intermediação, também circulam transeuntes e clientes do comércio ali estabelecido, assim como camelôs, mendigos, artistas de rua e pregadores religiosos. Cada um desses grupos de atores faz apropriações diferenciadas e concomitantes do espaço, é importante reter.

Porém, é o conjunto de usos e apropriações desse espaço ligados à busca e oferta de oportunidades que constitui, para nós, aquilo que analiticamente distinguimos como o "território da procura de trabalho"; são esses usos do espaço, e não outros, que aqui importam e que serão explorados. Com isso, podemos concluir também que uma das características espaciais daquela situação social é o compartilhamento do espaço com outras situações sociais. A grande visibilidade e a facilidade de acesso àquele espaço que pode ter atores sociais externos àquela situação, também são características espaciais que acabam por influenciar a dinâmica da situação de procura e as interações que ali transcorrem, como veremos adiante.

No que toca os interesses dessa pesquisa, os atores que usam e se apropriam daquele espaço na dinâmica da situação de procura de trabalho são os que realmente nos importam. Dentre todos os 
atores atuantes nessa dinâmica, quatro grupos deles são fundamentais, pois formam o núcleo básico da situação de procura, sem os quais a dinâmica de procura ali não existiria. São eles: i) os funcionários das agências de emprego, ii) os funcionários dos serviços correlatos à procura de trabalho, iii) os plaqueiros e iv) os demandantes de trabalho. Nos itens seguintes será feita uma análise da situação de procura de trabalho a partir da atuação e das interações tendo em vista, justamente, esses quatro grupos de atores essenciais. Por que esses atores especificamente? É isso que se pretende responder ao longo do trabalho de descrição das características e da atuação de cada

tipo de ator e instituição. As descrições que se seguem não cumprem o papel de mera ilustração, mas de exposição de uma análise da situação social estudada através do papel de cada ator/instituição que ali ganham existência .

Ainda que a sistematização das informações sobre a situação de procura seja feita através do papel desses atores específicos, o espaço continuará em jogo, já que é um dos elementos constituintes da situação de procura e da atuação e interação desenvolvida por esses atores específicos. Porém, a partir daqui o espaço aparecerá sobretudo através da forma como é mobilizado ou como orienta a conduta dos atores dessa situação. O espaço estudado é ocupado e apropriado por uma multiplicidade de atores e cada tipo de ator é, em conjunto e em interação com os demais, responsável também pela construção da situação estudada. O papel da atuação e da interação entre os atores na constituição da situação social da procura de trabalho que ali toma lugar é a dimensão que se procurará analisar nos próximos itens. Com essas descrições buscar-se-á desvelar as características dos atores (e as características das instituições de que fazem parte, quando isso for cabível), suas relações com o espaço e com os outros atores e suas formas típicas de performance e atuação.

O que se segue é uma forma, entre muitas possíveis, de organização e sistematização de observações, relatos e informações secundárias concomitantemente a uma tentativa de exercício sociológico pautado tanto no uso das noções e conceitos apresentados, quanto na criação de classificações para a interpretação da realidade que serviu como base empírica.

\section{As agências de emprego}

As agências de emprego são instituições fundamentais na constituição daquela situação de procura de trabalho. Sem desconsiderar os outros serviços que lá são oferecidos e as vagas divulgadas diretamente pelas empresas contratantes de mão de obra na rua, é justamente a concentração de agências de emprego que constitui a principal razão pela qual os demandantes de 
trabalho procuram aquele espaço, segundo seus próprios depoimentos. A maior parte das vagas de trabalho lá ofertadas é intermediada pelas agências de emprego; elas estão no centro das iniciativas de procura de trabalho naquele território; vale dizer, a procura passa por elas e pelas relações que os atores com elas estabelecem, a través de seus funcionários. Além disso, a conduta do demandante de trabalho é construída com base nas representações sociais difundidas por esse tipo de instituição e é construída para ser encenada dentro dela. As agências de emprego não são atores, no sentido interacionista do termo, mas são núcleos concentradores de atores que interagem com outros a partir de seu lugar nessas instituições e com práticas e discursos pautados nas regras, códigos e representações próprios a cada instituição. As agências, enquanto instituições, operam por meio de seus funcionários, que são os atores. Mas esses atores não podem ser considerados sem que se leve em conta as características da instituição a qual representam e vice-versa.

Os funcionários das agências de emprego são os atores que dão voz às representações dessas instituições e interagem com os demais atores em nome delas, e, por isso, constituem um dos grupos de atores determinantes da dinâmica da procura. Aqueles funcionários responsáveis pela recepção e pela seleção foram privilegiados nessa análise tanto por serem os que estabelecem relações e interações mais freqüentes e diretas com os demandantes dentro da agência, como porque da natureza dessas interações pode depender, inclusive, o sucesso na procura. Foram entrevistadas 4 recepcionistas, 4 selecionadores, 1 coordenadora de desenvolvimento e treinamento, 1 coordenador de assessoria de imprensa, e 1 estagiária de seleção, conforme quadro abaixo.

\section{Quadro 3.1.Características dos funcionários entrevistados nas agencias}

\begin{tabular}{|l|l|l|l|l|l|}
\hline Função & Agencia & Nome & Idade & Escolaridade & Formação \\
\hline Recepcionista & Agencia 1 & Juliana & 19 & E. Médio Compl. & ----------- \\
\hline Recepcionista & Agencia 3 & Paty & 20 & E. Superior Incompl & Administração \\
\hline Recepcionista & Agencia 5 & Ana & 20 & E. Superior Incompl & Comunicação \\
\hline Recepcionista & Agencia 6 & Fabiana & 22 & E. Médio Compl. & --------- \\
\hline Selecionadora & Agencia 1 & Heloísa & 35 & E. Superior Compl & Psicologia \\
\hline Selecionadora & Agencia 2 & Tânia & 40 & E. Superior Compl & Psicologia \\
\hline Selecionadora & Agencia 3 & Ricardo & 30 & E. Superior Compl & Psicologia \\
\hline Selecionadora & Agencia 4 & Carolina & 27 & E. Superior Compl & Psicologia \\
\hline Estagiária de seleção & Agencia 4 & Paula & 22 & E. Superior Compl & Psicologia \\
\hline $\begin{array}{l}\text { Coordenadora } \\
\text { desenvolvimento } \\
\text { treinamento }\end{array}$ & Agencia 2 & Carla & 40 & Pós-graduação & Psicologia \\
\hline $\begin{array}{l}\text { Coordenador de assessoria } \\
\text { de imprensa }\end{array}$ & Agencia 2 & Mario & 35 & Pós-graduação & Jornalismo \\
\hline
\end{tabular}

Fonte: Levantamento de campo, 2009. 
Os plaqueiros são funcionários das agências que também estabelecem interação direta e freqüente com os demandantes, mas terão seu papel e performance analisados num item particular (item 5) devido ao caráter especial que adquire nessa dinâmica e porque, atuando na rua e não dentro da agência, estabelecem um tipo de relação muito diferente com o espaço, com os demandantes e com os outros atores que ocupam a rua.

As numerosas agências de emprego da Rua Barão de Itapetininga são um grande atrativo para as pessoas à procura de trabalho. A rua e suas transversais concentram mais de sessenta agências. $\mathrm{O}$ mercado de intermediação de mão de obra que se constituiu no Centro, na rua Barão de Itapetininga e ruas adjacentes, tornou aquele um local indispensável na rota de um tipo de demandante de trabalho; não é sem razão que ele é o local é referido por alguns entrevistados como a "rua do emprego". Essa concentração de agências acabou por atrair um conjunto de serviços conexos à procura de trabalho. Muitas empresas se aproveitam do poder de atração de demandantes de trabalho que aquele espaço possui para fazer, sem a intermediação das agências, a divulgação de vagas de trabalho disponíveis, o que acaba potencializando esse poder de atração do espaço. Relatos dos funcionários dessas agências de emprego sugerem que esse mercado começou a se estabelecer por lá a partir dos anos 1980 e se consolidou ao longo dos anos 1990. A conjunção de dois motivos foi citada como fator de atração das empresas para aquele local: o fácil acesso por meio dos mais diversos tipos de transporte e os aluguéis razoavelmente baratos, pela tendência de deterioração do Centro. A questão do fácil acesso não é nada desprezível se pensarmos na quantidade de pessoas que uma agência tem que atrair para conseguir extrair um pequeno número de candidatos que se encaixe nas vagas de que dispõe. Isso era especialmente importante nos anos 1980 e 1990, quando a internet não era usada para divulgação de vagas e captação e cadastro de candidatos. Naquela época, o maior desafio era atrair quantidades numerosas de candidatos, segundo depoimentos de funcionários. $\mathrm{O}$ problema da atração de candidatos foi sendo superado à medida que o local passou a concentrar mais e mais agências e se tornou "a rua do emprego". Hoje em dia o problema da captação candidatos vem sendo contornado também com as ferramentas da internet. A grande dificuldade dessas agências, segundo relatos de funcionários diversos, é não a simples atração de demandantes, mas de "bons demandantes", como argumentaremos a seguir.

Essas agências, por suas características estruturais e pelos dispositivos físicos do local em que estão estabelecidas, têm uma forma de operação muito particular. A divulgação de vagas e captação de candidatos na rua é uma das características mais peculiares. Essa estratégia acaba por influenciar toda a dinâmica de procura de trabalho naquele espaço e a interação de todos os atores que fazem 
parte daquela situação social. Justamente por isso, ao fim desse tópico, usarei essa característica para diferenciar essas agências entre si.

As agências de emprego que operam na situação estudada integram o mercado de intermediação privada de mão de obra de São Paulo, aquele que se caracteriza por ser o mais consolidado do país (Guimarães, 2007-b, 2007-c). Conforme discussão apresentada no capítulo 1, sabemos como transcorreu o processo de constituição e consolidação desse mercado de intermediação de mão-de-obra no Brasil, assim como a importância que vem adquirindo o intermediador no processo de convergência entre um posto de trabalho e um candidato e as características mais gerais desse mercado. Mas as agências daquele "território de procura" possuem algumas características específicas e operam de forma curiosa, isso porque essas agências estabelecem uma relação vital com a rua e com o espaço externo a elas, como desenvolveremos a seguir; e uma relação muito peculiar com os demandantes de trabalho, a qual é condicionada por algumas regras implícitas à dinâmica daquela situação e também pelo espaço. Em seguida apresenta-se um quadro com as características mais gerais das agencias investigadas. As informações que ali constam são provenientes dos discursos dos funcionários entrevistados, das observações e de pesquisas nas páginas dessas empresas na internet. 
Quadro 3.2: Características das agências de emprego investigadas

\begin{tabular}{|c|c|c|c|c|c|c|c|}
\hline Agencia & $\begin{array}{c}\text { Estrutura e } \\
\text { espaço }\end{array}$ & $\begin{array}{c}\text { Características } \\
\text { gerais }\end{array}$ & $\begin{array}{l}\text { Serviços } \\
\text { ofertados }\end{array}$ & $\begin{array}{l}\text { Captação de } \\
\text { candidatos }\end{array}$ & $\begin{array}{l}\text { Perfil das } \\
\text { vagas }\end{array}$ & $\begin{array}{c}\text { Candidatos que } \\
\text { atrai }\end{array}$ & Dificuldades \\
\hline 1 & $\begin{array}{l}\text { Ocupa três salas de um } \\
\text { edifício. Estrutura média e } \\
\text { organizada. } \\
\text { Possui site. }\end{array}$ & $\begin{array}{l}\text { A grande característica é } \\
\text { a variedade de serviços, } \\
\text { dos clientes, e dos tipos } \\
\text { de vagas intermediadas. }\end{array}$ & $\begin{array}{l}\text { Captação } \\
\text { Seleção } \\
\text { Terceirização } \\
\text { Estágios }\end{array}$ & $\begin{array}{l}\text { Rua (através de } \\
\text { plaqueiro) } \\
\text { Recepção } \\
\text { (recebe } \\
\text { currículo) } \\
\text { Cadastros on- } \\
\text { line. }\end{array}$ & $\begin{array}{l}\text { Variadas, mas } \\
\text { principalmente } \\
\text { vagas } \\
\text { operacionais. }\end{array}$ & $\begin{array}{l}\text { Candidatos dos } \\
\text { mais diversos } \\
\text { tipos sociais, } \\
\text { etários e } \\
\text { educacionais. }\end{array}$ & $\begin{array}{l}\text { Captação de } \\
\text { candidatos adequados } \\
\text { para cada tipo de } \\
\text { vaga em curto tempo. }\end{array}$ \\
\hline 2 & $\begin{array}{l}\text { Ocupa três salas de um } \\
\text { edifício Decoração jovem e } \\
\text { descontraída. } \\
\text { Cerca de } 350 \text { funcionários } \\
\text { e } 5.000 \text { empresas-cliente } \\
\text { espalhadas pelo Brasil. } \\
\text { Possui site. }\end{array}$ & $\begin{array}{l}\text { Exclusivamente estágios. } \\
\text { É a segunda maior } \\
\text { empresa desse nicho. Se } \\
\text { diferencia por discurso } \\
\text { jovem, práticas modernas } \\
\text { de seleção e por atrair } \\
\text { candidatos mais } \\
\text { qualificados. }\end{array}$ & $\begin{array}{l}\text { Captação } \\
\text { Seleção } \\
\text { Terceirização } \\
\text { Headhunting }\end{array}$ & $\begin{array}{l}\text { Cadastros on line } \\
\text { (Um milhão e } \\
\text { quinhentos mil } \\
\text { estudantes } \\
\text { cadastrados) }\end{array}$ & $\begin{array}{l}\text { Estágios para } \\
\text { ensino médio e } \\
\text { ensino superior }\end{array}$ & $\begin{array}{l}\text { Jovens } \\
\text { estudantes do } \\
\text { ensino médio e, } \\
\text { principalmente, } \\
\text { do ensino } \\
\text { superior. }\end{array}$ & $\begin{array}{l}\text { Captação de } \\
\text { estagiários de áreas } \\
\text { específicas, como a } \\
\text { Engenharia. } \\
\text { Adaptação às novas } \\
\text { leis de dos estágio. }\end{array}$ \\
\hline 3 & $\begin{array}{l}\text { Possui mais } 3 \text { filiais. Ocupa } \\
\text { um espaço pequeno, tem } \\
\text { menos de } 10 \text { funcionários } \\
\text { e, uma infra-estrutura } \\
\text { simples. } \\
\text { Possui site }\end{array}$ & $\begin{array}{l}\text { Especializada em vagas } \\
\text { para telemarketing. }\end{array}$ & $\begin{array}{l}\text { Captação, } \\
\text { Seleção } \\
\text { Terceirização } \\
\text { para a área } \\
\text { de } \\
\text { telemarketing }\end{array}$ & $\begin{array}{l}\text { Rua (através de } \\
\text { plaqueiro) } \\
\text { Recepção } \\
\text { (recebe } \\
\text { currículo) } \\
\text { Cadastros on line }\end{array}$ & $\begin{array}{l}\text { Principalmente } \\
\text { vagas para } \\
\text { telemarketing, } \\
\text { e outras vagas } \\
\text { operacionais. }\end{array}$ & $\begin{array}{l}\text { Jovens sem ou } \\
\text { com pouca } \\
\text { experiência e } \\
\text { escolaridade } \\
\text { média. }\end{array}$ & $\begin{array}{l}\text { Captação de grande } \\
\text { volume de candidatos }\end{array}$ \\
\hline 4 & $\begin{array}{l}\text { Ocupa espaço pequeno, } \\
\text { dividido em seis salas, tem } \\
12 \text { funcionários. Possui } \\
\text { mais } 5 \text { filiais e vai abrir } \\
\text { mais três. } \\
\text { Possui site. }\end{array}$ & $\begin{array}{l}\text { Atendimento a um único } \\
\text { cliente, a maior empresa } \\
\text { de call center de SP. } \\
\text { Preenche, em média, } \\
1.500 \text { vagas desse cliente } \\
\text { por mês. }\end{array}$ & $\begin{array}{l}\text { Captação } \\
\text { Seleção }\end{array}$ & $\begin{array}{l}\text { Rua (através de } \\
\text { plaqueiro) } \\
\text { Recepção } \\
\text { (recebe } \\
\text { currículo) } \\
\text { Cadastros on line } \\
\text { Telefone }\end{array}$ & $\begin{array}{l}\text { Operador de } \\
\text { telemarketing } \\
\text { (exclusivament } \\
\text { e) }\end{array}$ & $\begin{array}{l}\text { Jovens sem ou } \\
\text { com pouca } \\
\text { experiência } \mathrm{e} \\
\text { escolaridade } \\
\text { média. }\end{array}$ & $\begin{array}{l}\text { Captação de grande } \\
\text { volume de candidatos }\end{array}$ \\
\hline 5 & $\begin{array}{l}\text { Filiais espalhadas dentro e } \\
\text { fora do Brasil. } \\
\text { Empresa estruturada e } \\
\text { estabelecida no mercado. }\end{array}$ & $\begin{array}{l}\text { Variedade de serviços e } \\
\text { vagas ofertadas }\end{array}$ & $\begin{array}{l}\text { Captação } \\
\text { Seleção } \\
\text { Terceirização } \\
\text { Headhunting }\end{array}$ & $\begin{array}{l}\text { Recepção } \\
\text { (recebe } \\
\text { currículo) } \\
\text { Cadastros on line }\end{array}$ & $\begin{array}{l}\text { Muito variadas. } \\
\text { Dividas em } \\
\text { estágios, } \\
\text { administrativas } \\
\text { e operacionais. }\end{array}$ & $\begin{array}{l}\text { Candidatos dos } \\
\text { mais diversos } \\
\text { tipos sociais, } \\
\text { etários e } \\
\text { educacionais. }\end{array}$ & $\begin{array}{l}\text { Captação de } \\
\text { deficientes físicos. }\end{array}$ \\
\hline 6 & $\begin{array}{l}\text { Ocupa espaço pequeno, } 7 \\
\text { funcionários, não possui } \\
\text { filiais e nem site. }\end{array}$ & $\begin{array}{l}\text { Agência pequena e com } \\
\text { muita dificuldade de } \\
\text { captar clientes. Em } \\
\text { alguns momentos opera } \\
\text { de portas fechadas. }\end{array}$ & $\begin{array}{l}\text { Captação } \\
\text { Seleção }\end{array}$ & $\begin{array}{l}\text { Rua (através de } \\
\text { plaqueiro) } \\
\text { Recepção } \\
\text { (recebe } \\
\text { currículo) }\end{array}$ & $\begin{array}{l}\text { Vagas } \\
\text { operacionais }\end{array}$ & $\begin{array}{l}\text { Candidatos com } \\
\text { pouca } \\
\text { qualificação. }\end{array}$ & $\begin{array}{l}\text { Captação de } \\
\text { empresas-cliente. }\end{array}$ \\
\hline
\end{tabular}




\subsection{As agências da Barão de Itapetininga: características, atuação e interação de seus funcionários com os outros atores}

As agências de emprego do entorno da Rua Barão de Itapetininga são espacialmente enraizadas e, majoritariamente de pequeno porte. Muitas delas operam unicamente naquele espaço ou possuem, no máximo, mais uma filial. Essas agências pequenas, típicas daquele território, operam com poucos funcionários, em média, menos de dez, segundo observações e relatos de funcionários. A grande maioria dessas agências, pela falta de estrutura, faz principalmente seleção e recrutamento de candidatos, enquanto que a terceirização e a sub-contratação fica mais por conta das agências de médio e grande porte, de acordo com informação do mesmo funcionário referido acima.

Já no que diz respeito às vagas intermediadas, a maioria daquelas agências não aderiu à tendência de especialização em nichos de mercado e trabalha com as mais variadas vagas, o que se pode observar nos anúncios colocados nas ruas e em suas páginas na internet, embora a maioria delas tenda a intermediar vagas de má qualidade (baixa qualificação e /ou remuneração), como previsto pelas pesquisas citadas no capítulo 1 para as empresas de pequeno porte. A grande maioria das vagas exige Ensino Médio como pré-requisito e, em alguns casos, cursos técnicos, mas ali a principal exigência que se vê nos anúncios é a "experiência comprovada em carteira". Para cargos administrativos os conhecimentos de informática são um pré-requisito importante. São poucas as ofertas de vagas que exigem formação superior e idiomas, mas existem. As vagas oferecidas por essas agências se concentram, principalmente, na área de Serviços. As vagas ofertadas em maior número são para as funções: vendedor, promotor de vendas, operador de telemarketing, recepcionista, vigilante, serviços gerais e manutenção; isso com base na observação sistemática das vagas ofertadas na rua e de informações dos funcionários das agências entrevistados. Os tipos de vagas oferecidas acabam condicionando o perfil dos demandantes que acorrem àquele território, como exploraremos no item 7 desse mesmo capítulo. Por ora, adianta-se que esses demandantes são majoritariamente jovens, com escolaridade média, e, por constrangimentos sociais diversos, os quais serão explorados adiante, encontram-se numa busca urgente e pouca seletiva, aceitando trabalhos pouco qualificados e mal remunerados.

As agências normalmente possuem uma área comercial, responsável pela captação e pela relação com os clientes, as empresas que pagam pela prestação do serviço de intermediação de mãode-obra. Além da área comercial, a outra área fundamental à operação dessas agências é a área de seleção, formada por psicólogos (as), especializados (as) em recursos humanos que comandam os processos seletivos. Essas duas áreas são os pilares de operação de qualquer agência de 
intermediação de mão-de-obra. Podemos dizer que a área comercial cuida dos clientes, enquanto a área de seleção cuida dos candidatos e envia os selecionados para a empresa cliente. Entre essas duas pontas do processo de trabalho das agências, há a divulgação das vagas, a captação dos clientes, a recepção dos currículos, sem falar, é claro, de todo processo administrativo interno, realizado pelas áreas jurídicas e de contabilidade e pela manutenção e limpeza do espaço.

O processo básico de trabalho de uma agência começa pela captação de clientes e é seguido pelo recebimento de pedidos e demandas desses clientes. A partir das demandas para preenchimento de vagas de trabalho, é criada uma estratégia de divulgação de vagas para alcançar os candidatos, de forma a conseguir um número determinado de candidatos em um determinado prazo, tais como firmados em contrato. Alcançados os candidatos, inicia-se o processo de seleção que conduzirá alguns deles para a empresa cliente. Via de regra, é o cliente que dá a palavra final para a contratação dos candidatos selecionados pela agência. Cabe registrar ainda que essas agências são muito influenciadas pelas fases de expansão e retração do mercado de trabalho. Por exemplo, nos meses que antecedem as festas de fim de ano ou a páscoa a demanda de trabalho nas agências aumenta devido ao grande volume de contratações temporárias nas áreas de serviços e indústria. Já no período que antecede o dissídio, abril e maio, as contratações caem consideravelmente, e assim, diminui o trabalho e o lucro dessas empresas.

No que diz respeito à problemática espacial, as agências de emprego devem ser abordadas de duas formas. Primeiro, por suas locações internas e, segundo, pelos usos que as agencias fazem de espaços externos às suas locações, como das ruas do território de procura. É possível adiantar, portanto, que as agências se distribuem por sub-espaços daquele território e nele atuam de forma dispersa e diferenciada, tanto em seus espaços internos, quanto nas ruas.

No que diz respeito às locações internas, as agências de emprego operam em salas dentro de edifícios e galerias da região, as quais são geralmente acessadas por escadas e elevadores. Do ponto de vista dos dispositivos físicos internos, elas possuem um lay out simples. Essas locações se caracterizam por possuir, em sua entrada, algumas poucas cadeiras ao lado ou de frente para uma mesa ou balcão onde se sentam as recepcionistas, as quais são responsáveis pelo fornecimento de informações e pela coleta e triagem dos currículos entregues pelos demandantes. Além do espaço da recepção, essas agências são subdivididas em salas onde são realizadas as diversas fases do processo de seleção como provas, exames escritos, dinâmicas de grupo e entrevistas com os selecionadores. As salas nas quais se realizam esses processos mais internos e administrativos são pouco visíveis por quem se encontra na recepção. As agências de médio porte, que operam com mais funcionários e 
fazem diversos processos seletivos concomitantemente, operam em espaços maiores. A recepção das agências são espaços importantes para a dinâmica da situação de procura, pois ali demandantes de trabalho interagem com funcionários desses estabelecimentos e com outros demandantes. Ou seja, ali acontece a interação entre concorrentes às mesmas vagas e entre candidatos e intermediadores.

Já no que toca à relação dessas agências com os espaços externos às suas locações repetimos que, no que se refere às formas de captação de candidatos, elas dependem, algumas mais e outras menos, do poder de atração de demandantes que aquele território possui e da divulgação de vagas feita nas ruas, por plaqueiros ou através de anúncios colados em paredes, muros e postes. Isso porque, como citado, elas operam em salas pouco visíveis. O que acontece nos espaços internos das agências depende muito dos processos de divulgação, captação e atração que se realizam na rua. Essa importante relação entre espaço interno e rua é estabelecida pelas agências através da figura do plaqueiro. Ele é fundamental não só por isso, mas também porque desempenha múltiplas funções, como será argumentado no item dedicado especificamente ao papel desse ator na situação. Por ora, basta dizer que a primeira relação dos demandantes com as agências se faz ou via plaqueiros na rua, ou via recepcionistas, no interior de cada empresa. Porém, pelo custo de manutenção de uma ou várias salas e pela eficiência de captação de candidatos através de plaqueiros e anúncios, algumas empresas, especialmente as menores e pouco estruturadas, operam de portas fechadas, prescindindo do contato com os demandantes na sua recepção e recebendo currículos apenas por intermédio de internet e plaqueiros, diminuindo o número de funcionários e reservando para o seu espaço apenas atividades internas como captação de empresas-clientes e processos seletivos. Isso reforça a idéia de que a relação de grande parte das agências com o espaço e com os processos que se realizam nas ruas daquele território é muito grande. São poucas, mas existem, porém, aquelas empresas que, mais estruturadas e consolidadas no mercado, têm uma capacidade de atração de candidatos que independe do poder de atração daquele território. Essas empresas maiores não contratam plaqueiros, não divulgam vagas na rua, à medida que oferecem vagas de melhor qualidade e captam candidatos primordialmente ou exclusivamente por internet. A relação das agências com o espaço da rua é, portanto, um fator que condiciona a dinâmica geral da situação de procura e ao mesmo tempo pode diferenciar essa empresa entre si dentro daquele território.

Como se pode entrever, a relação que as agências estabelecem com os demandantes de trabalho pode variar. Ela pode se estabelecer através dos plaqueiros, na rua, ou das recepcionistas, no interior de suas locações. Algumas agências mantêm as portas fechadas, recebendo currículos apenas por internet ou pelo intermédio dos plaqueiros, como adiantado e muitas funcionam com as 
portas abertas e recebem diretamente os currículos. Nesse último caso, os currículos são entregues a uma recepcionista, a qual geralmente olha o CV e confere alguns dados na presença do demandante, certificando-se da veracidade de algumas informações ou requisitando informações complementares como pretensão salarial, disponibilidade para viajar ou trabalhar no período noturno. Conforme relatos de funcionários das agências esse procedimento pode incluir a anotação de observações sobre cor e aparência física da pessoa à procura de trabalho, o que os demandantes não sabem, embora alguns suspeitem. Juliana, a recepcionista da "Agência 1" disse que quando a agencia está recrutando para vagas de atendimento ao público como recepcionista e vendedor, por exemplo, ela é instruída a anotar de lápis no currículo a cor do candidato e se ele é gordo ou magro. Isso porque, para algumas empresas-cliente, essas características fazem diferença e, como ela disse que “infelizmente é o cliente que decide no final", é melhor nem encaminhar os candidatos que não se adequam às "exigências" da vaga. Ironicamente, essa informante era negra.

Os recepcionistas configuram um "ator-chave" da dinâmica de funcionamento desses estabelecimentos. Esses funcionários geralmente atuam sozinhos ou em duplas e são jovens; há predominância de mulheres nas recepções das agências. No interior das agências é esse funcionário que estabelece uma primeira interação com os demandantes de trabalho e, por estabelecer com ele uma relação visual, pode iniciar o processo de julgamento do candidato, transmitindo para os selecionadores não só informações complementares ao currículo, mas também impressões sobre aparência e estética. Essa interação, apesar disso, é geralmente muito curta e composta, basicamente, por perguntas dos recepcionistas e não dos demandantes. Como grande maioria dos demandantes não sabem que já podem estar sendo avaliados, a interação com os recepcionistas é formal, principalmente por ser dentro da agencia, mas descomprometida. Muitas vezes essa interação que se dá na recepção entre funcionário e demandante é entre jovens de idades, escolaridades e condições sócio-econômicas muito semelhantes, o que a torna mais equilibrada e diminui o constrangimento que pode haver por parte dos demandantes.

È importante notar que, tanto através dos plaqueiros quanto através das recepcionistas, a princípio, a relação do demandante com a agência de emprego é mediada por um instrumento fundamental: o currículo. Só para dar um exemplo, funcionários da "Agencia 4", afirmaram que recebem mais de 600 currículos por dia. Os selecionadores entrevistados foram categóricos em dizer que a maioria dos candidatos não sabe fazer um "bom currículo". No site da "Agencia 3" os demandantes dispõem de dicas, como um longo e detalhado documento sobre "como fazer currículo". Do ponto de vista das agências, o bom currículo é conciso e objetivo, deve ter, no 
máximo, duas páginas. Dados incompletos, como ausência das referências dos trabalhos anteriores e as respectivas datas, assim como erros de português são imperdoáveis, segundo o levantamento de campo e Hirano (2007). Currículos feitos à mão ou com fotos informais e/ou indecentes também podem sepultar chances $^{43}$, segundo relatos de recepcionistas e selecionadores. No currículo, logo após a apresentação dos dados pessoais completos (endereço, telefone, e-mail, idade e estado civil) deve vir o que se chama de "objetivo" ou "cargo pretendido" que expressa exatamente o tipo de atividade que o demandante está buscando; esse tópico seria fundamental porque é ele que ordena a triagem dos currículos. Os demandantes não são classificados pelas agências pelo trabalho que eles já fizeram, mas pelo trabalho que eles pretendem fazer.

Os currículos são separados segundo o item "objetivo" ou "cargo pretendido" e dentro de cada uma desses grupos de currículos previamente separados é que outros itens como experiência, escolaridade e qualificação são avaliados. É importante registrar que antes da avaliação da trajetória profissional e escolar do indivíduo, dois fatores são usados numa triagem complementar: pretensão salarial e local de moradia. Demandantes que moram muito longe do local do trabalho oferecido são eliminados da concorrência, assim como aqueles que têm pretensão salarial muito superior à que será oferecida. A pretensão salarial e o local de moradia foram muito citados entre os funcionários das agências como fatores eliminatórios logo no começo do processo de seleção. Ricardo, selecionador da "Agência 3" disse que sabe que é injusto, mas que são as próprias empresas contratantes que exigem que a moradia dos candidatos seja próxima ao local de trabalho, o que representaria uma economia com vale transporte e diminuiria o problemas com possíveis atrasos. Com algumas empresas isso pode ser negociado. Nesses casos em que pode haver negociação desse pré-requisito, ele disse que não descarta currículo bom de candidato que não more tão próximo ao local de trabalho. Porém, com alguns clientes essa condição é inegociável e já passa ser anunciada junto com os pré-requisitos da vaga. Ele disse ainda que a moradia fora da região metropolitana, por exemplo, pode ser um problema para os candidatos, pois só de falar para o cliente que o candidato mora em outra cidade ele se assusta. No que diz respeito à pretensão salarial, segue depoimento da coordenadora de seleção de uma agencia que trabalha exclusivamente com vagas para operador de telemarketing:

"A primeira coisa que a gente olha no currículo é a pretensão salarial, se estiver muito fora do que vai ser oferecido a gente nem perde tempo entrando em contato com essa pessoa. Ou ela não aceitaria o trabalho ou, se aceitasse, trocaria de trabalho na hora que recebesse uma proposta melhor. Mas, se a pretensão salarial for só um pouco maior do que vai ser oferecido a gente não descarta, não, porque a gente sabe que, 
se estiver precisando, a pessoa aceita. A pretensão salarial diz muito sobre o perfil do candidato, sobre suas expectativas... " (Carolina, coordenadora de seleção da "Agencia 4")

Assim, após o recolhimento dos currículos, começa o processo de triagem. Os currículos que não são selecionados para alguma vaga disponível no momento vão para um arquivo, onde permanecem por alguns meses, até que sejam jogados no lixo. Assim, o banco de currículos é constantemente renovado, o que faz com que os demandantes, de tempos em tempos, procurem as mesmas agências para deixar os mesmos currículos que eles deixaram e foram eliminados. Após uma ou várias triagens de currículos, as agências entram em contato, por telefone ou e-mail, com aqueles candidatos que melhor se encaixam nas exigências das vagas intermediadas no momento.

Vencida a fase da triagem, começa uma outra relação entre agências e demandantes, que se dá através de um processo seletivo. Nesse momento, aquela pessoa em busca de trabalho que deixou um currículo na agência, deixa de ser um demandante de trabalho e se torna um candidato a uma vaga. Esse candidato passa a se relacionar com aquela empresa não mais através de um plaqueiro ou de uma recepcionista, mas, através de um (a) selecionador (a), uma das figuras mais importantes de uma agência de emprego.

A figura do selecionador é fundamental em qualquer agência de emprego, pois é o responsável pelo processo seletivo. As agências possuem uma equipe de seleção, geralmente composta por estagiários, selecionadores e um coordenador. Esse tipo de funcionário tem, invariavelmente, formação em Psicologia e experiência na gestão de recursos humanos. Eles possuem credencial requerida para aplicar testes psicológicos, conduzir as dinâmicas de grupo e as entrevistas e, ao final, elaborar um parecer sobre o candidato, o qual será utilizado na decisão de selecioná-lo ou não, o que deixa entrever a autoridade que eles têm. $O$ selecionador deveria ser capaz de avaliar não somente o candidato, mas também entender muito bem a demanda da empresa cliente, pois só assim seria possível o cruzamento entre oferta e demanda de trabalho com sucesso e satisfação de ambas as partes. O poder desse tipo de funcionário na dinâmica do processo de convergência entre uma vaga e um candidato é enorme. Esse personagem é a autoridade que dá voz às representações da gestão de recursos humanos e as coloca em pratica através de técnicas as mais diversas. Dentro da estrutura de uma agência, os selecionadores ocupam papel vital, assumem uma função muito especializada e possuem certo status. A interação desse personagem com os demandantes é marcada por uma desigualdade muito grande entre os papéis que ambos desenvolvem na situação de procura, a qual deixa os últimos submissos às decisões dos primeiros. 
Existem diversos tipos de processos seletivos. Quase todos eles envolvem, no mínimo, duas etapas: um exame escrito e uma entrevista. Frequentemente esse processo pode ser incrementado com as famosas "dinâmicas de grupo". Quanto melhor a vaga, mais detalhado e refinado o processo seletivo e vice-versa. Uma das agências investigadas pode fazer processos seletivos que passem por mais de sete fases, dependendo da rigidez do cliente, que vão dos mais variados exames escritos, passando por exames psicológicos e dinâmicas de grupo diversas até chegar na entrevista. Mas, geralmente, os processos seletivos realizados pelas agências de emprego daquele cluster são mais simples, compostos de, pelo menos, um exame escrito e uma entrevista e, em muitos casos, incrementado com uma dinâmica de grupo. Os exames escritos envolvem conhecimentos gerais, português, matemática e redação e, dependendo do cargo, exames específicos podem ser aplicados como os de conhecimentos de informática, de idiomas ou de técnicas e procedimentos de trabalho. Os processos seletivos para as vagas de operador de telemarketing, por exemplo, envolvem também um teste de dicção ${ }^{44}$, como foi possível acompanhar durante uma observação do trabalho de campo. Esse teste consistia na repetição de determinadas palavras por todos os que candidatos que tinham passado nos exames escritos. Esse procedimento era realizado numa sala com todos os demandantes que, naquele momento eram concorrentes, e cada um tinha que fazer a sua sequiência de repetição na frente dos outros. O clima de competição entre os demandantes era visível assim como o constrangimento e humilhação por parte daqueles que não conseguiam cumprir a repetição corretamente. Segundo relato da funcionária que coordenava essa seleção, é comum demandantes deixarem o processo seletivo chorando. Essa mesma situação foi narrada por outro selecionador que descrevia as dinâmicas de grupo, mas segundo, ele, isso se dava pelo despreparo emocional dos candidatos e não pela possível crueldade das técnicas aplicadas nos processos seletivos. A dinâmica de grupo consiste em um conjunto de atividades, realizadas conjuntamente pelos candidatos à uma vaga com a supervisão de um ou mais selecionadores. Essas atividades, que segundo definição de uma das coordenadoras da "Agencia 2", seriam "lúdicas" e estariam baseadas em técnicas psicológicas de apreensão das características da personalidade dos participantes. Na dinâmica de grupo a interação é entre candidatos, que concorrem pelas mesmas vagas, e entre candidatos e selecionadores. Uma interação se dá em termos de concorrência enquanto a outra em termos de julgamento e, ambas, podem ser emocionalmente difíceis para os demandantes em interação. Esse

\footnotetext{
44 A observação de parte de um processo seletivo para vagas de operador de telemarketing pôde flagrar esse teste de dicção que consistia na repetição das seguintes palavras por parte dos candidatos às vagas: cadastro, registro e problema. Essas seriam "palavras-chave" para captar problemas de diç̧ão e de pronúncia e são muito utilizadas por qualquer operador de telemarketing.
} 
tipo de situação coloca muita pressão no desenvolvimento de uma performance que deixe uma boa impressão no selecionador e intimide o concorrente. Aqui entram dois elementos importantes que atuam não só na interação durante o processo seletivo, mas na situação de procura de trabalho: a concorrência entre demandantes e a conduta socialmente esperada do "bom demandante de trabalho".

A entrevista é a última parte do processo; só chega nela quem passou pelas etapas anteriores, e se trata de uma conversa individual com o (a) selecionador (a). Aqui não há o peso da concorrência entre candidatos e da comparação com os concorrentes; entretanto, a interação entre selecionador e demandante é mais direta e, portanto, mais intimidadora. Na entrevista, temas da trajetória profissional e pessoal do candidato são abordados pelo selecionador que deve ter a capacidade de avaliar tanto a capacidade de comunicação, compreensão de questões, raciocínio e elaboração de respostas quanto características da personalidade dele, conforme relatos de todos os selecionadores entrevistados. Assim, aspectos os mais subjetivos possíveis são colocados em jogo e são determinantes do resultado final de uma competição por uma vaga. "Força de vontade", "vontade de vencer", "garra", “determinação", "pró-atividade", "comprometimento", "responsabilidade” são as características mais citadas entre os selecionadores entrevistados como aqueles indispensáveis a qualquer candidato, independente do tipo de vaga pretendida. Um exemplo é o seguinte texto voltado aos demandantes de trabalho, retirado do site de uma das agências investigadas e que vai ao encontro do discurso geral dos selecionadores: "Estar disponível no mercado de trabalho não é ser desempregado, é uma situação, não é uma condição estável e estática, mas sim mutável, que depende de você. A responsabilidade de sua vida não está nas mãos das outras pessoas e sim de você mesmo!" E, além dessas características gerais que qualificam qualquer candidato como "batalhador" e "responsável”, outras características específicas são requeridas, conforme o tipo de trabalho. De tal forma, "simpatia" e "carisma" são necessários aos vendedores, promotores de venda e operadores de telemarketing ativo. "Boa aparência" é imprescindível para vendedores e recepcionistas. "Seriedade" e "liderança" são características que são buscadas em candidatos à cargos de chefia ou coordenação. Assim, o conjunto de qualidades almejadas depende também da vaga a ser preenchida, o que pode sugerir que para vagas diversas haja não só a expectativa de características diferentes, mas também de condutas diferentes por parte dos demandantes.

Todas essas características subjetivas dos demandantes seriam apreendidas na dinâmica de grupo e, principalmente, na entrevista a qual, sendo o último passo do processo seletivo, é também o mais decisivo. A natureza da interação estabelecida entre selecionador e demandante é desigual, pois 
ao selecionador cabe o julgamento que será determinante do resultado final da seleção. Nesse processo de interação, demandantes podem fazer uso da técnica da manipulação de informações, assim como na elaboração do currículo, ressaltando umas em detrimento de outras de forma a desempenhar uma conduta de bom demandante de trabalho e a encenar um personagem que eles julguem mais adequado à vaga pretendida. Os selecionadores sabem que o recurso da manipulação de informações é utilizado e a eles cabe identificar o uso dessa técnica por parte dos demandantes nas entrevistas. O selecionador deve ser capaz de identificar a veracidade do discurso do candidato, através de sua própria forma de falar, isso, pois, como disse Tânia, da "Agencia 2" é fácil omitir ou inventar informações no currículo, mas não é nada fácil sustentar essa manipulação de informações numa interação face-a-face, ainda mais com um funcionário treinado para captar essas falhas; “a pessoa se entrega", ela disse.

Não à toa, as dinâmicas de grupo e as entrevistas são as fases mais temidas pelos demandantes, mas para os (as) selecionadores (as) é a parte mais fundamental do processo, pois, nas palavras de Carla, da "Agencia 2", oferece uma "amostra de comportamento e é exatamente a partir dessa amostra que os candidatos são avaliados". A princípio, independentemente do conteúdo da dinâmica ou da entrevista, as atitudes e gestos são analisados. As atitudes mais condenadas pelos selecionadores são: mascar chiclete, atender celular, falar gíria, falar muito baixo, falar muito alto, tremer, transpirar excessivamente, apresentar "tiques nervosos", sentar de perna aberta, vestir roupas muito informais ou indecentes. Esses gestos denotariam uma atitude displicente ou nervosa/ansiosa, ambas consideradas negativas. Nessas fases do processo seletivo, é fundamental que os demandantes consigam evitar também dois julgamentos considerados negativos pelos selecionadores, timidez e insegurança, os quais também seriam apreendidos tanto pelo discurso quanto pelos gestos.

A grande reclamação dos selecionadores é a falta de qualificação por parte dos candidatos e, principalmente, a falta dos atributos considerados fundamentais pelas técnicas da gestão de recursos humanos, tais como: saber vestir-se, portar-se e comunicar-se bem. Isso, os selecionadores insistem, é o mais difícil de encontrar nos candidatos e, muitas vezes, cabe à própria agência ensinar essa que se considera a "conduta ideal", através de conselhos informais durante a interação do selecionador com o candidato, ou mesmo através de cursos e palestras organizados pelas agências, com o objetivo de tornar os candidatos mais aptos a preencher as vagas disponíveis. A "Agência 1" oferece cursos preparatórios para os demandantes com freqüência. Porém, nem sempre há tempo para esse tipo de formação, pois a lógica desse mercado é, na maioria das vezes, ditada pela pressa no preenchimento 
dos postos. O selecionador da "Agencia 3" disse que muitas vezes é possível perceber que o candidato pode se encaixar bem na vaga, mas que precisa ser "lapidado" para passar nos processos seletivos. Seria possível, portanto, identificar quando a pessoa parece apta a desenvolver um trabalho, mas não está preparada para passar pelos processos que levam a ele, o que sugere que a conduta do bom demandante de trabalho não é a mesma do bom trabalhador. Reza o discurso dos selecionadores das agências que a conduta usual do demandante de trabalho que acorre àquele cluster de intermediação não corresponde à "conduta ideal do demandante de trabalho", ou, pelo menos, à conduta condizente com o discurso predominante entre os gestores de recursos humanos ${ }^{45}$. Três selecionadores entrevistados, Rodrigo, Ana Carolina e Raquel, usaram a mesma palavra "despreparados" para se referir, de forma genérica aos demandantes que procuram os estabelecimentos em que trabalham. O despreparo a que eles se referem diz respeito à falta de experiência e informação sobre como se portar no processo de procura de trabalho.

Cumpridas as fases do processo seletivo, candidatos devidamente avaliados, a agência encaminha o candidato selecionado à vaga ou um pequeno conjunto de candidatos para que a própria empresa escolha seu futuro funcionário. A partir de então é iniciado entre agência e candidato um processo burocrático que envolve documentos e contratos. Se a agência foi contratada apenas para selecionar e recrutar o candidato, a relação entre agência e demandante termina após esse processo. Se a agência foi contratada para treinar, terceirizar ou sub-contratar a mão-de-obra, a relação se estende um pouco mais no caso de treinamento, e se estende até o fim da relação de trabalho, no caso de terceirização ou subcontratação.

\subsection{As agências e a situação de procura: agências enraizadas na situação e agências independentes da situação}

Podemos dizer que no território de procura da Rua Barão de Itapetininga e redondezas existem agências de emprego de pequeno, médio e grande porte. As de pequeno porte são a maioria, porém, as de médio porte, como algumas das investigadas no trabalho de campo, são as que mais conseguem movimentar aquele espaço, pois oferecem um número maior e mais variado de vagas, atraindo, portanto mais demandantes. As de grande porte são extrema minoria, mas podemos citar pelo menos uma, a maior agência de intermediação brasileira tem uma filial lá.

Mas, para além da estrutura da empresa (tipo e volume de capital, capilaridade, número de filiais, número de funcionários), proponho uma divisão entre elas que passe antes pelo tipo de 
relação que elas tecem com aquele espaço em que estão estabelecidas e com os demandantes de trabalho, a partir de suas estratégias de captação de candidatos, já que são justamente as relações com o espaço e entre os atores da situação que mais interessam para o presente estudo.

Uma parte das agências é extremamente dependente da dinâmica de atração de demandantes daquele território da procura de trabalho, sendo o recebimento de currículos impressos, na recepção ou por plaqueiros, seu principal meio de captação de candidatos. Essas empresas não têm uma estratégia consolidada de captação de candidatos via internet, principalmente porque são empresas pequenas e, às vezes precárias, que não contam com uma estrutura mínima. Esse tipo de empresa pequena tende a terceirizar serviços diversos, como os jurídicos e de contabilidade, por exemplo. Além disso, não possuem um número grande de clientes ou clientes fixos, e, à medida que ficam à mercê das demandas desses podem enfrentar épocas de baixo movimento, nos quais não seja necessário e nem lucrativo ter um staff completo e disponível. Funcionando com uma certa instabilidade e precariedade, essas pequenas firmas não dispõem de muitas estratégias de divulgação de vagas e captação de candidatos, a não ser aquelas que se pode por em prática de forma rápida e barata na rua, através de plaqueiros e cartazes. Somado a esses fatores, podemos agregar também o fato de que essas pequenas agências intermediam vagas de muito baixa qualidade, procuradas por demandantes de mais baixo poder aquisitivo e escolaridade, que não necessariamente possuem acesso ou conhecimento para realizar uma busca virtual, e para os quais a divulgação na rua é mais eficiente. Essas agências são aquelas que considero as mais "enraizadas" na situação de procura, pois são extremamente dependentes da dinâmica daquela situação e do poder de atração daquele território.

Porém, nem só as de pequeno porte são tão dependentes do espaço. Uma das agências investigadas, a "Agência 4", aqui classificada como de médio porte, por fazer parte uma rede de cinco filiais no estado de São Paulo, e por intermediar mensalmente cerca de 1.500 vagas de operador de telemarketing para a maior rede de call center do estado, se mostrou extremamente enraizada na dinâmica daquela situação. Pelo grande volume de vagas que a agência tem que preencher mensalmente, a questão da urgência pauta o seu trabalho e, para tentar contornar esse problema, ela faz dois processos seletivos diários, um de manhã e um à tarde, com o maior número de candidatos possível, dos quais não se exige experiência, apenas Ensino Médio completo. Para alcançar um bom número de participantes para esses processos seletivos diários, a estratégia é abordagem na rua, através de plaqueiro ou panfleteiro, ou então através do recebimento de currículos na recepção da agência. Nesses casos, assim que confirmado que o demandante possui 
nível de escolaridade médio completo, ele é imediatamente convidado a participar do próximo processo seletivo, que pode ser realizado até naquele mesmo dia. A agência faz divulgação de vagas na internet, através de seu site próprio ou de outros portais que divulgam vagas, porém, o maior número de candidatos é alcançado na rua, disse a selecionadora dessa agência. E, no caso dessa agência, em que a maior dificuldade está na captação de um grande volume de candidatos e não tanto na adequação ao perfil da vaga (já que não se exige experiência), essa relação com o demandante que se dá na rua é fundamental, para não dizer vital à operação da firma. O plaqueiro dessa agencia é instruído a não apenas divulgar vagas, mas a abordar e convencer demandantes na rua a participarem desses processos seletivos diários. Em épocas em que a captação de candidatos se faz mais urgente, os funcionários internos da agência, inclusive selecionadores, descem à rua e ajudam o plaqueiro nesse processo de captação de candidatos. Essa agência citada como exemplo, apesar de ser médio porte, é extremamente enraizada na situação e no espaço estudado. Além da “Agência 4", a "Agência 6" também é extremamente dependente da dinâmica de captação na rua, já que, nem página na internet ela possui.

Algumas agências, que podem ser tanto de pequeno quanto de médio porte, e que, ainda que se utilizem do poder de atração daquele território de procura, desenvolvem outras estratégias de captação de candidatos e de mediação da relação com eles, de modo que não sejam tão dependentes daquela situação ou daquele espaço. Essas agências que estão numa situação intermediária entre as que são aqui denominadas como "enraizadas no território de procura" e as que são "independentes do território", também são bastante representativas. Elas possuem plaqueiros na rua, e recebem currículos impressos, mas também investem em divulgação e captação por internet, jornal ou em outros clusters da cidade, como os da Lapa ou de Santo Amaro. Essas agências intermediárias abrem seus leques de estratégias e investem nelas, sem, contudo, abrir mão das estratégias mais tradicionais que são aquelas enraizadas na rua, no espaço e na dinâmica da situação e atuam com um olho naquele território e o outro em outros espaços, sejam eles virtuais ou localizados em outros bairros da cidade. A "Agencia 1" e a "Agência 3" estariam nesse grupo.

Por último, há um conjunto pequeno de agências que são totalmente independentes da dinâmica de atração de demandantes daquele espaço. Elas não possuem plaqueiros nem colam cartazes na rua e, mesmo assim, atraem seus candidatos com sucesso. São empresas estabelecidas, consolidadas no mercado e que possuem "um nome conhecido" no ramo em que atuam, de forma que são "naturalmente" procuradas pelos demandantes. Não quer dizer que elas não se preocupem com divulgação, muito pelo contrário, mas que elas o fazem através de outros meios, os quais 
consideram, nas palavras da funcionária da "Agencia 2", mais "profissionais", mais "legítimos" e menos "improvisados" de divulgação de vagas e captação de clientes, como, por exemplo, internet, jornais, revistas, propagandas em diversos meios de comunicação e participação em feiras e eventos. Isso é possível, pois essas empresas investem muito em propaganda e marketing e têm condição financeira para isso, diferentemente das outras que atuam naquele espaço. Além disso, essa acaba sendo uma forma de se diferenciar simbolicamente das outras empresas que atuam ali. Duas das empresas investigadas se encaixam nessa categoria das agências independentes do território e da situação de procura. A primeira delas, a "Agencia 5" até recebe currículos impressos, mas alega que essa não é a estratégia que mais capta candidatos, e sim, a internet; sendo essa a maior rede de agência de empregos do Brasil, seu poder de captação de candidatos não é local ou espacialmente concentrado e ela é independente do território. A outra delas, especializada em intermediação de estágios e a segunda maior representante nacional desse ramo, nem recebe currículos impressos e a relação com os demandantes é exclusivamente feita através da internet, assim como as primeiras fases do processo seletivo (exames escritos e testes psicológicos). Pela forma de operação dessa última agência, ela não precisava estar estabelecida naquele cluster de intermediação de mão-deobra, à medida que é totalmente independente dele. Uma das coordenadoras dessa agencia disse que seu estabelecimento naquele espaço da cidade foi meramente casual e o principal motivo para se manter ali é o acesso facilitado por meios de transporte diversos. Inclusive, o perfil sócio-econômico do demandante que acorre àquela agência é bem diferente do demandante típico que circula na Rua Barão de Itapetininga. Isso, porque à medida que intermedia vagas para estágios, e não para empregos, já faz um corte de classe que se acentua pela razão de que a grande maioria dos estágios ali oferecidos são para estudantes universitários. O perfil de demandante almejado por essa empresa é de jovens cursando ensino superior em instituições respeitadas, preferencialmente públicas, e com amplos conhecimentos de idiomas estrangeiros. Esses jovens são captados pela empresa em suas instituições de ensino, em feiras e eventos e a partir de anúncios em meios de comunicação. Dessa forma, a coordenadora dessa agência afirmou que a instituição não possui uma relação importante com aquele território e nem tem interesse na captação de demandantes na rua, pois busca jovens muito diferentes daqueles que ali circulam.

Com isso, tentou-se mostrar um pouco da pluralidade existente entre as agências que atuam naquele território, ressaltando que essas diferenças podem ser vistas tomando como recorte a relação que elas estabelecem com o espaço e, por consequiência, com os demandantes. É claro que o porte e o poder da empresa naquele mercado acabam influenciando a relação que ela estabelece com o 
espaço, sendo mais ou menos dependente dele. Porém, não depende só disso, mas também do tipo de demandante que a agencia pretende alcançar, pois para o preenchimento de algumas vagas a captação de demandantes na rua é muito mais eficiente que em outros meios, e para o preenchimento de outras vagas ela é totalmente dispensável. Aqui importa principalmente a forma como cada tipo de empresa, independentemente do porte, se enraíza (ou não) no espaço estudado, e de que forma ela se relaciona com os atores que participam daquela situação de procura de trabalho.

\section{Os serviços correlatos à procura de trabalho: o "mercado de condutas"}

Esse item é dedicado a um amplo conjunto de estabelecimentos que conforma um mercado em torno da procura de trabalho, pois oferece serviços que estão direta ou indiretamente relacionados à ela e tornam aquele lugar mais atrativo para as pessoas em busca de trabalho. A princípio, o que está no centro do interesse nesse item, assim como no item anterior são instituições que operam como estabelecimentos comerciais. Esses estabelecimentos são, assim como as agencias, núcleos concentradores de atores que interagem com outros a partir de seu lugar e função nessas instituições e de acordo com práticas e regras próprias a cada uma dessas instituições. Tais estabelecimentos comerciais, enquanto instituições, operam por meio de seus funcionários, que são os atores. Além disso, nesses estabelecimentos ocorrem interações que também delineiam aquela situação de procura. Porém, pela pulverização desses estabelecimentos e pela quantidade enorme e diferenciada de serviços ofertados, é difícil dizer que aí existam praticas e representações sociais muito institucionalizadas. Exatamente por isso, a intenção não é fazer uma descrição detalhada desses estabelecimentos e dos atores aí envolvidos, mas mostrar, em termos gerais, como eles operam, o que eles ofertam, como se dá a relação com os seus clientes (os demandantes de trabalho) e,

principalmente, como esses serviços podem influenciar na dinâmica da procura de trabalho e na construção da conduta do demandante de trabalho.

Esses estabelecimentos, tratados aqui como parte da situação de procura são muito relevantes para aquela situação; são bem característicos daquele território e constituintes de um tipo de mercado peculiar, aquele que tem os demandantes de trabalho como clientes. Mais que isso, esse mercado dota os demandantes de instrumentos, qualificação e modos necessários a uma procura eficiente de trabalho; assim sendo, através da prestação desses serviços, lhes confere os códigos simbólicos e elementos materiais necessários à construção da "conduta de demandante de trabalho". Eles formam, assim, o que será doravante denominado um "mercado de condutas", dimensão central 
à compreensão do modus operandi do mercado de trabalho quando o observamos do ponto de vista do acesso às oportunidades ocupacionais e, notadamente, quando privilegiamos a dinâmica da situação de procura como o ângulo de reconstrução deste mercado. Tais serviços são fundamentais na medida em que dotam demandantes pobres e com pouca qualificação - e, às vezes, pouca ou nenhuma experiência de trabalho - daqueles conhecimentos, instrumentos e posturas requeridos para que se pleiteie entrar na competição por uma vaga de trabalho.

São múltiplos os serviços que se vende no mercado de condutas. Trataremos aqui de quatro deles: aquele ofertado pelos estabelecimentos de confecção e cópia de currículos, os que são providos nas lan houses, os treinamentos na forma de cursos, além de uma gama de outros serviços, de diversa natureza, de que trataremos mais acuradamente também adiante.

Esses estabelecimentos não são apenas muito numerosos, como crescem e se diversificam a cada dia, tal como se pode observar no curso das fases do trabalho de campo. A grande maioria deles é de pequeno porte, opera em salas improvisadas e conta com poucos funcionários, entre eles os plaqueiros e/ou panfleteiros que fazem a divulgação na rua; assim como as agências, eles também ficam localizados no interior de edifícios comerciais e galerias e muitos carecem de "braços externos" que os tornem visíveis aos seus potenciais clientes. As instalações são simples; em alguns casos até precárias. Esses estabelecimentos têm que cobrar barato pelos seus serviços e fazer diversas "promoções" para garantir a competitividade em meio a tanta concorrência. ${ }^{46}$ Se mais não fosse porque, além de complementares, precisam convencer o demandante inexperiente de que são cruciais para a sua performance eficaz. Atrair cliente é, assim, parte do processo de formar um nicho para sua própria existência e a política de preços competitivos pode ser um meio para tal; sem contar, como dito, que a clientela que aflui ao Centro e que, uma vez ali, enceta o tipo de procura aqui analisado, provem de grupos sociais de baixo poder aquisitivo (Guimarães e Melo, 2008).

\subsection{Confecção e cópias de currículos}

Os estabelecimentos que confeccionam currículos, apesar de muito pequenos, são muito numerosos, movimentados e requisitados, chegando a distribuir senhas e formar filas. Esses negócios oferecem aos clientes, para facilitar e agilizar o processo, uma espécie de portfolio dos seus serviços: uma pasta com os mais variados modelos de currículo e cartas de apresentação. Os modelos variam do ponto de vista estético e da quantidade de informações adicionais, deixando entrever quais são as formas eficientes de apresentação de si que, a juízo desses produtores de

\footnotetext{
46 ,Como, por exemplo, “currículo a R \$0,50”, “quarenta cópias de currículo a R $\$ 3,00 ”$ e "lista das agências de emprego da cidade a R\$1,00” Esses valores são reais e referentes a março de 2009.
} 
condutas, formam o leque de condutas normativamente aceitas pelas recepcionistas e selecionadores com que eles se defrontarão logo em seguida.

O cliente escolhe o seu modelo de currículo nessa pasta e, chegada a sua vez, é atendido por um funcionário que vai, a partir do modelo escolhido e da experiência de cada candidato, compor o currículo, personalizando-o. O processo de confecção de um currículo pode demorar algum tempo, dado que o cliente precisa oferecer muitos dados pessoais e contar sua experiência profissional. Vemos assim, e tal como indicado por Guimarães (2009), que a procura por meio de agencias privadas de emprego impõe ao demandante que realize (e pague por) atividades que, nas agencias do sistema público, não apenas são gratuitas como são parte do processo de trabalho da própria agencia. A firma produtora do serviço de montagem de CV, na verdade, antecipa, internalizando como sua, a tarefa de realizar a primeira entrevista para montagem do perfil do potencial candidato a qual, numa agencia sindical ou governamental é feita mediante uma entrevista inicial, com a funcionaria da linha de frente, que preenche o perfil daquele que se inscreve num refinado sistema informatizado de dados (o SIGAE), o qual já indica a existência de vagas que se adequem a este perfil (fazendo o tradicional "matching").

Mas, há uma especificidade que convém sublinhar e que faz deste procedimento uma rotina central ao mercado de condutas (e não uma rotineira inscrição para habilitar-se a uma vaga). Tal como ouvimos de um funcionário de um estabelecimento desse tipo, este é o momento de dotar o candidato do perfil e descrevê-lo por condutas que são as esperadas. No mercado de condutas é sempre preciso "melhorar" a trajetória real do demandante, "inventando ou escondendo algumas informações" ou "substituindo expressões simples por mais sofisticadas" e nisso residiria a "grande vantagem de pagar por um currículo ao invés de fazê-lo", para tomar as palavras de um dos nossos informantes, funcionário desse tipo de estabelecimento há um ano.

É justamente desse jogo de informações inventadas e escondidas que se faz um bom currículo, o que nos remete claramente a Goffman e à importância da manipulação das informações para a manutenção dos personagens. A confecção de um bom currículo estaria baseada num bom lay out, na objetividade, e na ciência de re-elaborar positivamente e com as palavras adequadas a experiência de cada um. Seguindo essa lógica, relatos apontam que a experiência de babá, de "cuidar de crianças" passa a ser nomeada como um trabalho como "baby-sitter", a faxineira (o) torna-se “ajudante de serviços gerais", a "recepcionista" pode ser descrita como "secretária" e assim por diante, tal como relatado por outra funcionária desse tipo de estabelecimento, formada em design gráfico, mas que ali trabalhava a três anos fazendo currículos e tirando cópias. 
Olhando pelo lado do produtor do serviço, onde se forma esta competência (como se adquire o senso do que o mercado demanda de modo a traduzir a trajetória e o perfil do demandante com os elementos esperados por que os examinará)? Foram entrevistados dois jovens que trabalham confeccionando e copiando currículos em estabelecimentos diferentes e ambos contaram que aprenderam sozinhos essa ciência. Os dois relataram que nunca receberam instruções detalhadas de seus superiores sobre a forma de elaborar os CV's. Disseram que desempenhavam essa função seguindo o que eles próprios consideravam que devesse ser um bom currículo, o que sugere haver certa arbitrariedade nesse processo de elaboração. Um deles disse que, na atividade de elaboração de currículo, é tudo uma questão de "bom português e bom senso"; outra entrevistada disse que aprendeu com as dicas dos professores da faculdade e com os meios de comunicação, como internet e televisão, os segredos de um bom currículo.

Porém, a grande dificuldade desse serviço não seria manipular positivamente informações, mas extrair dos demandantes as informações necessárias sobre sua própria experiência de trabalho. Os relatos dos dois funcionários entrevistados são semelhantes na afirmação de que muitos clientes não saberiam elaborar oralmente de forma cronológica e objetiva sua própria experiência de trabalho, o que demandaria desse funcionário alguma habilidade e paciência. Os dois entrevistados vivenciaram conflitos com clientes que não gostaram dos seus currículos. Há muita insatisfação com o tamanho do currículo, eles afirmam, pois os demandantes querem que os seus sejam "currículos extensos" enquanto os funcionários desses estabelecimentos tentam fazer "currículos objetivos", tal como pregam as agências. Às vezes é necessário convencer o cliente que é melhor omitir uma informação, disseram os dois entrevistados. Então, nessa interação pode haver tanto um trabalho de composição conjunta (funcionário e cliente) e colaborativa do currículo, quanto uma negociação das informações que devem compô-lo e até mesmo conflitos nesse processo. Durante observações em um desses estabelecimentos foi possível flagrar tanto expressões de satisfação quanto de insatisfação por parte dos clientes que pagam por seus currículos. Uma jovem que saiu insatisfeita disse que a atendente estava com "má vontade", não prestou atenção nos relatos de sua experiência de trabalho e omitiu trabalhos relatados no formato final do currículo sem consultá-la, o que ela não lhe satisfez. Apesar disso, disse que iria usar esse mesmo texto para não perder as cópias já feitas (e pagas), mas que o próximo currículo faria em outro estabelecimento. Assim, é possível perceber que essa interação entre funcionário e cliente pode ser conflituosa; o que é compreensível já que, ao final, o que está em jogo é a própria forma de interpretar e apresentar a trajetória profissional de cada um. Três demandantes entrevistados e que haviam pago pela elaboração de currículo, deixam entrever 
essa diversidade de desfecho: uma delas, referida acima, teve impressão negativa do serviço e da relação com a atendente ; os outros dois se mostraram satisfeitos com o serviço.

Como não poderia deixar de ser, os currículos seguem um tipo específico de linguagem e de composição gráfica (tamanho e estilo da fonte, margens e parágrafos), o que os torna muito padronizados. Ironicamente, ao tentar se diferenciar frente aos outros candidatos na procura, ao recorrer a esse tipo de currículo "diferenciado", o demandante se torna mais parecido com os outros que também recorrem a esse tipo de serviço, e são muitos os que o fazem, pois muitos demandantes declaram não saber preparar esse tipo de documento.

Feito o currículo o cliente pode ainda optar pelos serviços complementares: cópia dos currículos, envio pela internet, confecção de carta de apresentação, compra de pastas para guardá-los ou de listas de agências de emprego, para saber onde distribuí-los.

Mas é a cópia do currículo o serviço mais procurado; grande parte dos demandantes entrevistados afirmaram recorrer a este tipo de apoio, o que deixa entrever algo sobre a origem social do demandante que acorre à Barão; impressora não é um artefato que faça parte do ambiente domestico corrente. Mesmo quem já leva seu currículo pronto pode fazer cópias a preços promocionais; curioso que, nas copiadoras da Barão de Itapetininga, tais promoções são válidas apenas para currículos, outros materiais têm preço diferenciado. Oito dos vinte quatro demandantes entrevistados contaram que fizeram cópias de seus currículos nessas copiadoras do território de procura, aproveitando seus preços promocionais. Os demandantes de trabalho geralmente pedem de vinte a quarenta cópias de $\mathrm{CV}$, mas esse número pode chegar a cem, conforme observações e relatos dos funcionários das copiadoras e dos próprios demandantes.

É fundamental ressaltar que, sendo o currículo o instrumento mais elementar para dar inicio à procura em agências privadas, ao pagar por esse tipo de serviço, o demandante transfere muita responsabilidade para um estabelecimento comercial, e, mais concretamente, para um desconhecido, um atendente que, entre cinco e dez minutos tem que interpretar e recontar a sua trajetória e suas habilidades. Nesse momento, o demandante de trabalho perde sua autonomia ou parte dela na tarefa de contar sua própria história, à sua maneira, ressaltando atividades e qualidades que ele próprio julgue como positivas. A possibilidade de manipulação de suas próprias informações pessoais é igualmente transferida para outrem. Porém, a falta de domínio da linguagem formal e mesmo do uso de computador, assim como dos termos e dos formatos adequados pode ser tanta que compense essa transferência de responsabilidade e autonomia, a qual se concretiza numa relação mercantil, no âmbito do "mercado de condutas", tal como aqui denominado. Enfim, essas condutas podem sugerir 
não apenas quanto o mercado de trabalho lhes parece opaco, como quão inexperientes eles próprios se sentem para encetar a tarefa de buscar trabalho por meios mercantis.

\subsection{As lan houses}

As lan houses proliferaram na região há cerca de dois anos; elas passaram a ser muito utilizadas e não apenas para divertimento e comunicação, mas também para a procura de trabalho, já que tornou-se norma de boa procura colocar o endereço de e-mail no currículo como forma de contato.

A internet é utilizada não só para checar alguma oportunidade que tenha chegado via e-mail, como também buscar trabalho ativamente através do cadastramento em sites. Sendo assim, o demandante tem que se conectar com alguma freqüência à internet para não correr o risco de perder alguma oportunidade de trabalho que chegue através de seu endereço virtual. O computador pode, portanto, ser um instrumento tão necessário quanto um currículo na procura de trabalho; isso dá a medida de como mudam os procedimentos das agências de intermediação e, como, mais uma vez, transferem aos demandantes os custos, agora sob forma de investimentos no mundo virtual, para a obtenção de emprego. Mas, é certo que a democratização digital ainda tem que percorrer muitos passos; sendo assim, muitas pessoas que buscam emprego naquele cluster, por sua condição sócioeconômica, não possuem em casa computador ou acesso fácil à internet, conforme relatos dos demandantes entrevistados, daí porque dependem diretamente de estabelecimentos como as lan houses, que se multiplicam em todos os espaços da cidade. Assim, mesmo sendo o nosso objeto empírico a procura direta em agências de emprego, terminamos por encontrar que, com o passar do tempo, a interface entre procura direta e procura virtual se amplia e uma parte do processo de procura de trabalho se realiza virtualmente, mesmo para aqueles que apenas têm recursos para encetar a procura direta. E, mais interessante ainda, crescendo o interface com o mundo virtual - e ampliando-se a noção de espaço com que iniciamos o trabalho - essa busca passa a ter que se realizar complementarmente nesses outros estabelecimentos comerciais, as lan houses, razão pela qual ampliaram-se até elas as observações e entrevistas.

Muitas lan houses foram montadas em espaços que já ofertavam outros serviços, como os de confecção e cópia de currículo, aumentando, assim, o leque de oferta de serviços conexos à procura prestados pelo mesmo estabelecimento, num processo de ampliação de portfolio de atividades que lembra aquele que também mostramos que se passava com as agências, na descrição efetuada no item anterior. Alguns desses estabelecimentos, porém, funcionam apenas como lan houses; essas são 
maiores e têm equipamentos mais novos e internet mais rápida. Já aquelas que funcionam em espaços que oferecem outros serviços são de pequeno porte, equipadas com máquinas antigas e oferecem conexão à internet de má qualidade. As lan houses menores não chegam possuir nem dez computadores. A sua forma de operação é bem semelhante: o cliente, ao entrar no estabelecimento, se dirige ao balcão do atendente que faz um pequeno cadastro com suas informações pessoais e indica para qual computador o cliente deve se encaminhar. Alguns estabelecimentos exigem que o cliente pague adiantado pelo uso do serviço por um determinado tempo, o qual pode ser prorrogado; em outros estabelecimentos o cliente paga após o uso.

O horário do almoço e o fim da tarde são os horários em que esses estabelecimentos ficam especialmente lotados. Ou seja, há uma complementaridade entre movimento na rua e movimento nas lan houses, a denotar a importância destas para os demandantes; assim, quando o movimento na rua é maior, o movimento nas lan houses é menor e vice-versa. Apesar do grande fluxo de pessoas, não há muita interação entre os usuários nas lan houses; ali, a relação é com a máquina, e não se pode perder tempo, já que por tal relação se paga por minuto. Sem embargo, é muito comum os usuários fazerem perguntas e pedirem dicas sobre procura virtual de trabalho para os atendentes e funcionários desses estabelecimentos, conforme relatos deles próprios e observações dentro das lan houses. Um dos informantes, funcionário a 7 meses de uma pequena lan house localizada em um edifício da Barão de Itapetininga, disse que já criou conta de e-mail para muitos clientes que pediram sua ajuda, assim como já foi solicitado a auxiliar no preenchimento de cadastro em sites de agências de emprego e portais virtuais de procura. A relação entre os demandantes e os funcionários desses estabelecimentos é menos intensa e mais curta do que no caso da manufatura de currículos, mas também pode ser uma interação mais amistosa quando baseada no pedido de favores e dicas.

Como observado, algumas lan houses daquela região vendem uma lista com sites para procurar trabalho, o que seria um equivalente dos guias das agencias de emprego da cidade. Já outras se responsabilizam pela própria procura virtual, enviando o currículo do cliente para uma lista de agências. Essa atividade é realizada pelo mesmo funcionário que atende, cadastra e cobra dos clientes, nos horários em que o movimento está fraco. Aqui é interessante notar que o demandante que acorre a esse tipo de serviço transfere o próprio processo de procura para um estabelecimento comercial. É no oferecimento desse tipo de serviço que as lan houses da região da Rua Barão de Itapetininga se diferenciam, respondendo às necessidades de parte do público que freqüenta aquele espaço em busca de trabalho, tornando esse público cliente de mais um tipo de serviço conexo à procura e sobrepondo, inclusive, as dimensões presencial e virtual da procura de trabalho. Dos 
demandantes entrevistados, Juliana, Ana Maria e Sandro contaram que utilizaram lan houses da região ao longo do dia de procura de trabalho.

\subsection{Os cursos}

No Centro da cidade o oferecimento de cursos é abundante. Especificamente na região estudada proliferam os cursos de informática, s os cursos de idiomas, os cursos preparatórios para exames de concursos públicos e até mesmo cursos preparatórios para processos seletivos.

Os cursos de idiomas e de informática são os mais abundantes e possuem qualidade e preços que variam muito. Porém, pode-se destacar o grande oferecimento de cursos intensivos a preços populares. Um dos demandantes entrevistados, Adriano, de 19 anos, era técnico em Informática e, além de um curso superior nessa área, ele cursava seu segundo curso intensivo numa escola de informática próxima à Barão de Itapetininga; com razão, pois ele acreditava que "quanto mais cursos no currículo, melhor".

É notável também o crescimento dos cursos preparatórios para concursos públicos naquela região. Esse crescimento responde ao aumento das oportunidades no serviço público e ao crescente interesse em entrar para as estáveis e protegidas carreiras no funcionalismo público. Dois demandantes que foram entrevistados, Silvana e Édson, afirmaram que concomitantemente à procura regular de trabalho, também estavam estudando para concursos públicos. Walter disse que o seu sonho mesmo era passar num concurso para polícia, ele já havia prestado concursos algumas vezes sem sucesso e, enquanto não conseguia passar, tentava achar outro trabalho.

Mas, esse mercado que gira em torno dos concursos públicos não pára nos cursos e nas aulas particulares, também diversifica seus produtos. As apostilas de apoio ao estudo para esses exames são vendidas tantos nos próprios espaços que oferecem os cursos, quanto em lojas especializadas nesse tipo de material, em pequenos e precários estandes, na internet e nas bancas de jornal do Centro, como nas duas bancas de jornal da Rua Barão de Itapetininga. Conforme declarações dos próprios vendedores, essas apostilas são muito procuradas. Elas são preparadas de acordo com o conjunto de conteúdos exigidos para cada concurso e cargo posto específico. Conforme são abertas inscrições para um determinado concurso público, surgem no mercado apostilas destinadas especificamente aos candidatos que vão prestá-lo. O preço dessas apostilas pode variar de $\mathrm{R} \$ 10,00 \mathrm{a}$ $\mathrm{R} \$ 100,00$, dependendo do tipo de cargo, e da quantidade de matéria e de exercícios. O aumento da procura por serviços que capacitam para exames de concursos públicos, assim como o aumento do 
investimento nesse tipo de estratégia para sair do desemprego estão relacionados a algumas importantes questões que serão exploradas em detalhe no capítulo 4.

Existem ainda os cursos voltados diretamente à preparação do "bom demandante de trabalho". Eles nos importam de perto, dada a transparência com que deixam entrever os códigos a serem apreendidos no mercado de condutas. Esses pretendem ensinar tanto o discurso quanto a postura apropriados para as diversas situações de procura, como entrevistas e dinâmicas de grupo. Pretendese ensinar, além do tipo de roupa e do que escrever num currículo, principalmente o que dizer nesses momentos e de que forma dizê-lo para demonstrar confiança, auto-estima, pró-atividade, iniciativa, espírito de liderança, habilidade para trabalhar em equipe entre outros requisitos valorizados pelos agentes da intermediação e da gestão de mão-de-obra, como já apontamos no item anterior. Almejase ensinar, através de truques e frases feitas, a conduta "ideal" de um demandante de trabalho. Esses cursos podem ser oferecidos por consultorias, por palestrantes autônomos ou pelas próprias agências de emprego da região, mediante pagamento dos candidatos ou gratuitamente, com o objetivo de divulgação da empresa e/ou de treinamento e preparação de candidatos para posterior encaminhamento para as empresas-cliente.

Essa é uma iniciativa interessante de ser observada também do ponto de vista da lógica empresarial e da alocação de custos desenvolvida por essas firmas. Assim, se é certo que as agências privadas de emprego cobram das empresas usuárias, que nelas colocam as vagas e não dos demandantes pelos serviços que prestam, é igualmente verdadeiro que elas "desenvolvem novos produtos" que lhes permite legitimamente cobrar ao demandante pelo "novo serviço" que prestam.

Muitos demandantes entrevistados demonstraram interesse quando havia alguma referencia a esse tipo de serviço durante as entrevistas. Isso porque, como retomaremos no capítulo a seguir, há um conjunto de habilidades e práticas, de natureza fortemente subjetiva, que são valorizadas pelo mercado de trabalho e pelo mercado de intermediação, as quais os demandantes de trabalho nem sempre interiorizaram e dominam e, por isso mesmo, os tornam vulneráveis na concorrência por vagas. Eles próprios assim o percebem e elaboram. Esse conjunto de códigos e habilidades que nem todos tiveram a oportunidade de aprender "naturalmente", seja em seus meios sociais de origem, seja no curso de sua experiência de trabalho e vida, são almejados como dimensões importantes do capital simbólico requerido pela procura, e tornam-se, desse modo, bens que podem ser consumidos ou como práticas que podem ser artificialmente aprendidas mediante algumas lições ou palestras. 


\subsection{Os outros (e múltiplos) serviços}

Há ainda no Centro de São Paulo uma concentração de alguns outros serviços, muito claramente associados à situação de desemprego ou ao empreendimento da procura e obtenção de trabalho, como: i) os de advocacia, especialmente os escritórios de advogados trabalhistas, ii) os provedores de exames médicos admissionais e demissionais, iii) as agências financiadoras de crédito e agiotas. Mas há também outros serviços típicos do Centro tradicional de São Paulo, como iv) os sebos e antiquários e v) o "comércio do ouro" (compra e venda de metais e pedras preciosas). Toda essa gama de serviços se concentra na região da Rua Barão de Itapetininga, ocupando seus edifícios e galerias e completando a face visível deste território da procura de trabalho. Muitos, como os primeiros citados, são procurados por pessoas na busca de emprego, mas, vale frisar, não servem exclusivamente a estas.

É muito comum que demandantes de trabalho (especialmente os que também são desempregados) possuam problemas e/ ou pendências relativos a seus trabalhos anteriores, por isso os advogados trabalhistas lhes são muito úteis. Vimos que, não raro quando o demandante tem alguma questão trabalhista para resolver, pode unir essa atividade à própria procura de trabalho no Centro. Miro, um dos demandantes de trabalho entrevistado, tinha pendências jurídicas com o seu antigo patrão e iria procurar ali nas redondezas um advogado para tratar de suas questões trabalhistas, após distribuir seus currículos. Já o farto oferecimento de exames médicos admissionais e demissionais parece bem conveniente, já que grande parte do público que ali se encontra foi demitida e almeja, tanto quanto busca, ser readmitida no mercado de trabalho, sendo, portanto, parte da potencial clientela desse tipo de serviço.

Nesse território da procura de trabalho não podemos descartar as agências financiadoras de empréstimo, que se multiplicam e invadem a rua, com seus promotores oferecendo "crédito fácil e sem comprovação de renda" assim como os tão tradicionais agiotas. Dada a privação material que normalmente acompanha o desemprego, a procura por esse tipo de recurso pode ser necessária para a manutenção da sobrevivência e para sustentar o próprio processo de procura de trabalho, que tem custos (transporte, alimentação, roupas, confecção e/ou cópia de currículos, entre outros). Segundo os discursos, essa é uma estratégia que, a princípio se busca evitar, mas que é muito utilizada principalmente na ausência de bicos ou trabalhos irregulares e quando o recurso às redes pessoais de apoio, como parentes, amigos e vizinhos, já não pode ser mais acionado. Carmem, Carlão, Silmara, Ana Paula e Wagner, dentre os demandantes de trabalho entrevistados, afirmaram que tomaram 
dinheiro emprestado nesse tipo de agencia financiadora, recentemente, para contornar as dificuldades financeiras.

A venda de bens pessoais como jóias, por exemplo, também pode ser outro recurso, pois o que não falta por ali são os estabelecimentos que compram e vendem ouro, metais e pedras preciosas. $\mathrm{O}$ número de plaqueiros que divulga venda e compra de ouro ali é bastante grande. Existem ainda naquelas proximidades vários sebos, antiquários e estabelecimentos que costumam comprar outros tipos de bens pessoais, estratégia que também pode ser utilizada em caso de necessidade financeira.

Todos esses expedientes podem ser acionados para garantir a sobrevivência, o consumo e a procura de trabalho na ausência de ocupação remunerada. Mas, sobretudo, todos eles mostram como, nesse particular espaço de procura, não são apenas a acessibilidade e a concentração de provedores de oportunidades que podem fazer dele o mais importante território de procura na mais importante metrópole brasileira, ela mesma campeã nos meios mercantis de procura. A isso se agrega toda essa gama de serviços complementares que multiplica os atrativos para que o demandante, dos mais diversos quadrantes da grande São Paulo, escolha ali investir seu esforço na procura de trabalho, já que ele pode também ser complementado por outras atividades que lhes são conexas. Retomaremos o assunto no capitulo 4, explorando também os outros elementos que o Centro disponibiliza e que para ele atraem o "jovem demandante", figura dominante neste "território de procura".

Convém também retomar e alinhar alguns fios com respeito a outro aspecto que nos importa aqui, e de modo particular, qual seja a característica que faz desse "território de procura" também um "mercado de condutas", voltado a dotar as pessoas de atributos, recursos e instrumentos que lhes permitam sair do desemprego ou sobreviver durante o desemprego. Vimos até aqui como essas atividades são operacionalizados através da interação direta com os demandantes e com a verbalização de suas dificuldades e necessidades, as quais os serviços almejam resolver. Porém, há que ter em mente que muitos desses serviços surgem como uma resposta às demandas da própria dinâmica da procura naquele espaço; é o caso, por exemplo, do que antes referimos como a venda de guias de agências, necessária devido à própria disposição das agências, em espaços invisíveis aos transeuntes. Ou do enorme número de estabelecimentos que fazem xerox, que responde também a uma necessidade gerada pela dinâmica de procura que se dá ali, a qual é baseada numa relação entre agência privada e demandante, que requer ser mediada pela entrega, em mãos, de um currículo impresso. E, por ultimo, é o caso da proliferação recente das lan houses que responde não só ao crescimento e intensificação do uso da internet pela população, mas também ao aumento de espaços 
virtuais de procura de trabalho e à necessidade de cadastros virtuais em sites de agências que, como descrito no item anterior, operam muitas vezes "de portas fechadas". Assim esses serviços surgem como resposta às novas e antigas exigências da relação entre demandantes e agências e fazem, inclusive, uma mediação da relação entre eles. Por isso esses estabelecimentos são considerados fundamentais na composição da situação de procura de trabalho analisada.

Há que destacar que uma geografia particular preside a distribuição espacial desse mercado; ele também é espacialmente concentrado. Esse tipo de serviço opera, via de regra, próximo a concentrações de agências de emprego, o que podemos notar não só Centro, mas também na Lapa e em Santo Amaro, a sugerir que a concentração espacial de um tipo de mercado permite a proliferação de serviços conexos a ele; no caso estudado, o mercado de intermediação, capitaneado pelas agências fortalece o "mercado das condutas", provido por todos esses diferentes tipos de estabelecimentos; e vive-versa. Isso torna a concentração espacial interessante para ambos e a economia de aglomeração tem efeitos virtuosos para ambos os segmentos. No rastro desse processo, o "território da procura de trabalho" se torna mais denso e diverso no que se refere às práticas e usos do espaço ligados à procura de oportunidades ocupacionais.

Finalmente, e fechando este item, vimos até aqui que tais serviços surgem justamente com o objetivo de preencher as lacunas e contornar as dificuldades da construção do "bom demandante de trabalho", dotando-os de alguns atributos básicos à procura, tais como a qualificação (através dos mais diversos cursos) ou mesmo, do instrumento mais fundamental à procura, tal como o currículo. A procura de trabalho e a própria composição da conduta de demandante de trabalho - com seu discurso, suas práticas e instrumentos próprios - são ali mercadejadas na forma de serviços. Preparando o terreno para o argumento que será desenvolvido no capítulo a seguir - de que a construção da conduta do demandante é múltipla -, foi possível documentar aqui que tal construção passa crescentemente pela esfera mercantil, por um processo de compra e venda, constituindo aquilo que denominamos (por mais estranha que possa parecer a idéia) um "mercado de condutas". Ele é o espaço para adquirir ou aprender códigos e instrumentos que, não tendo sido forjados na socialização familiar, escolar ou na trajetória ocupacional prévia - e sendo crescentemente requeridos pelas firmas - vão ser mobilizados, por exemplo, nas agências de emprego. A procura por trabalho é uma situação em que essa conduta - multiplamente constituída - deve ser desempenhada, ao modo de Goffman, independentemente da forma como foi construída, vivenciada e internalizada; pois isso não importa, no momento crucial e decisivo da encenação, como tal conduta foi apreendida e quanto ela se encontra internalizada, mas, sim, se está ou não sendo adequadamente representada. 


\section{Os plaqueiros: os intermediadores entre as agências e os demandantes}

Na passagem pela Rua Barão de Itapetininga chama a atenção o grande número de "plaqueiros" ou "homens-placa" 47 . Eles não desempenham ali a simples função de portadores de uma placa e veiculadores de informações, mas podem ter um papel ativo na captação de clientes para os mais diversos tipos de negócios que se desenvolvem no Centro e, muito particularmente, na captação de candidatos às vagas das agências de emprego e das consultorias de recursos humanos que ali se concentram. A dinâmica da procura de trabalho no Centro, tanto pelo ângulo daqueles que procuram emprego, quanto pelo funcionamento de significativa parcela do mercado de intermediação de mão-de-obra ali estabelecida, tem grande relação com a atividade desse trabalhador, motivo pelo qual ele dever ser entendido como um ator fundamental da situação estudada e sua atuação merece ser explorada em detalhe. As descrições e análises seguintes são baseadas em estudos anteriores sobre os plaqueiros daquele espaço (Cerqueira, 2000; Vieira, 2007), em observações sistemáticas, em conversas e em entrevistas com sete plaqueiros que atuam como funcionários das agências de emprego e consultorias de recursos humanos daquela região.

A ocupação de plaqueiro é negativamente representada na sociedade; figurada como uma atividade desqualificada e sujeita a ser ridicularizada ${ }^{48}$. Poder-se-ia pensar que tal estigmatização seria o resultado da baixa remuneração e da forma precária pela qual as relações de trabalho se configuram nessa ocupação. Porém, acredita-se que, mais ainda, a própria natureza do trabalho do plaqueiro, sua função e os gestos que a atividade implica são associados a uma imagem de desqualificação; diria que se trata de uma "Desqualificação cujo sentido não se esgota nos índices $e$ nos salários... [Mas]que nasce de uma imagem de indignidade" (Desjours, 1987, pp. 49). Arrisca-se aqui a sugerir que tal estigmatização resulte da articulação da imagem de atividade desqualificada com a exposição do corpo do trabalhador em nome da publicidade de uma empresa, da qual ele é

\footnotetext{
47 "Plaqueiro" é o nome que adotarei para me referir ao indivíduo que desempenha a ocupação de portar uma placa e divulgar o conteúdo nela anunciado. Cabe ressaltar, essa não é a única forma de nomeação possível. Recolhi-a, num leque de possibilidades, por entendê-la como a que melhor se presta a conotar a especificidade de tal trabalho. Entre eles é esse o termo mais comum, assim como também o termo "o placa". São freqüentes construções como "fulano é placa" ou "o placa da agência X", por mais estranhas que elas possam soar, a princípio.

48 Uma boa ilustração disso pode ser a campanha publicitária do vestibular de 1997 para uma universidade particular; ali se exibia um plaqueiro vestindo uma placa com o seguinte texto: "Evite empregos ridículos como o meu”. Ver foto em Cerqueira (2000, pp. 24). A campanha foi suspensa pelo Conselho Nacional de Auto-Regulamentação Publicitária (CONAR) acusada de desrespeitar a dignidade da pessoa humana e de discriminar o trabalho legal e honesto.
} 
apenas um funcionário. $\mathrm{O}$ aspecto da exploração do próprio corpo parece ser aquele que mais desperta a idéia de que tal atividade implica em humilhação para aquele que a desempenha.

Apesar da representação social negativa dessa ocupação, pretende-se enfatizar aqui a importância desse personagem na dinâmica de funcionamento das agências de emprego do Centro. Um dos fatores que explica a importância desse trabalhador é, como dito antes, a visibilidade que ele dá a pequenos negócios que são pouco visíveis porque se localizam dentro de edifícios ou galerias; ou ainda porque, em se tratando de negócios clandestinos e ilícitos (como a maioria dos negociadores de ouro, passes, tickets e celulares), de fato, lhes convém a pouca visibilidade, e se escondem ${ }^{49}$. Os plaqueiros são, nesse sentido, "a cara" do negócio, a parte do estabelecimento que está exposta. Mas são mais que isso, tal como será explorado doravante.

A função de plaqueiro era majoritariamente ocupada por homens idosos, senhores aposentados ou, se não pelo menos com idade para sê-lo; alguns, inclusive, com a saúde bastante debilitada. Porém, ao longo dos últimos quatro anos (desde que a primeira observação de campo se realizou), essa característica vem mudando. Primeiro, os jovens começaram a ocupar as placas das lan houses e dos estabelecimentos que fazem e copiam currículos. O número de jovens cresceu bastante e, mais recentemente, as mulheres passaram a ocupar aquele espaço e essa função. Antes, encontrar uma "mulher-placa” era raríssimo; hoje, entretanto, elas já existem em número considerável. Apesar disso, ainda é possível afirmar que os plaqueiros são majoritariamente homens e senhores, mesmo reconhecendo-se a diversificação em curso, tanto de gênero quanto de idade. Por isso preserva-se o termo que os referencia no masculino.

\subsection{Atividades e práticas dos plaqueiros}

O porte da placa pode se traduzir tanto no ato de segurá-la ${ }^{50}$, como no de vesti-la, em forma de um colete que contém impressas as informações a serem divulgadas. ${ }^{51}$ Aqueles que seguram a placa trabalham para escritórios de advogados trabalhistas e consultórios médicos, mas, sobretudo, veiculam negócios tais como compra e venda de ouro, de passes, de tickets de metrô, de celulares usados e de cartuchos de impressora, empreendimentos muitas vezes ilícitos. Já os que vestem a

\footnotetext{
49 É importante chamar a atenção aqui para o fato de que a dinâmica do centro conta com o que Cerqueira (2000) chama de "teias de ilegalidades", que são um conjunto de práticas ilícitas que se desenvolvem na rua, que são de conhecimento público, e com as quais havia, na época de sua pesquisa, uma certa condescendência por parte da polícia. Atualmente a repressão da polícia é constante.

50 A placa, do tipo que é segurada, é feita de madeira e afixada em uma haste que pode ser de madeira ou ferro e mede em torno de dois metros de comprimento, aplaca é segurada por essa haste.

$51 \quad$ Esse colete é feito de um plástico flexível e colorido e pode ser, tanto na parte da frente, quanto na de trás, subdividido em pequenos bolsos de plástico transparente, onde se colocam os papéis com as informações a divulgar.
} 
placa em forma de colete, trabalham principalmente para as agências de emprego e para as consultorias de recursos humanos, razão pela qual neles concentro a atenção a partir de agora ${ }^{52}$.

Portando suas placas, eles ficam espalhados pela rua; alguns de pé, outros sentados em um banquinho, normalmente em pequenos grupos de três ou quatro. Os plaqueiros que veiculam compra e venda de ouro ficam parados na rua e gritam para atrair atenção, enquanto que os das agências de emprego normalmente não gritam, mas circulam mais intensamente pela rua devido à maior liberdade que a placa em forma de colete lhes dá. Alguns ficam o dia todo sentados no banquinho, outros ficam o dia todo de pé, e outros intercalam, um pouco de pé e um pouco sentados. Alguns circulam pelas ruas do território, outros ficam sempre no mesmo lugar. Isso depende da idade desses trabalhadores (os mais velhos ficam mais sentados) e das instruções dadas pelas agências contratantes. Enquanto eles trazem no corpo ou nas mãos os anúncios das vagas de trabalho, os demandantes e transeuntes, se interessados, param e observam as placas; muitos fazem perguntas, pedem informações. Essa interação visual e verbal entre plaqueiros e demandantes de trabalho é muito típica daquele espaço e fundamental na situação de procura de trabalho na Barão (Vieira, 2007).

Figura. 3.4. Foto dos plaqueiros divulgando vagas na Rua Barão de Itapetininga

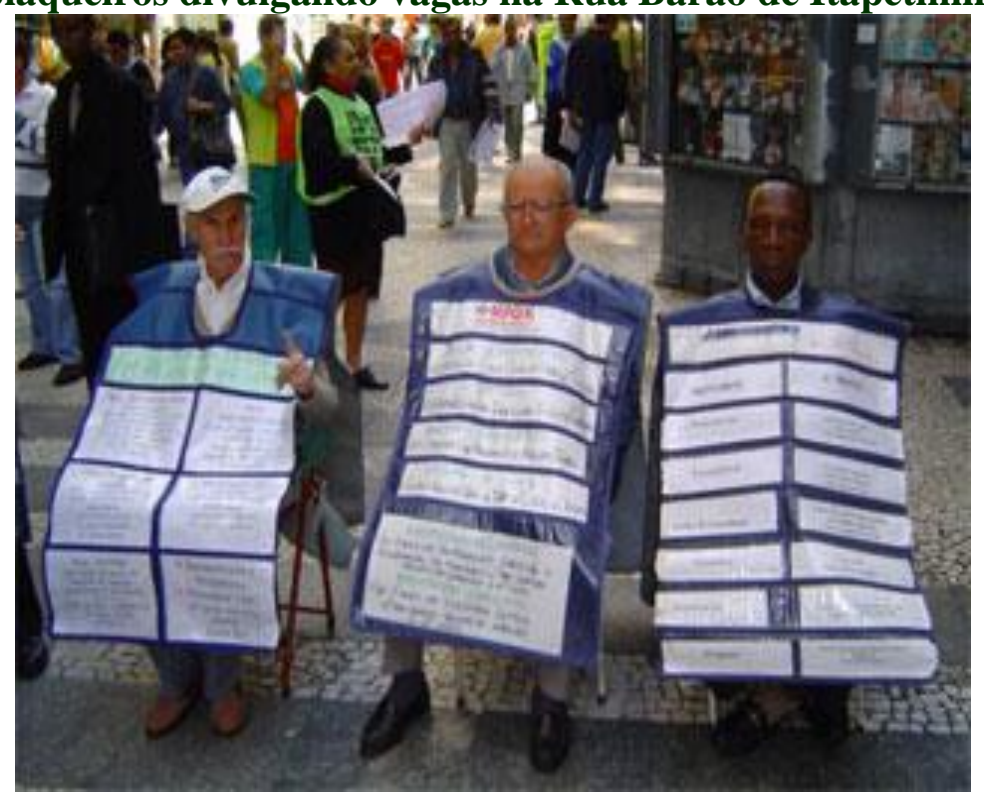

Fonte: Site do Centro de Estudos da Metrópole (www.centrodametropole.org.br/divercidade/numero4)

Para melhor entender o cotidiano do plaqueiro, suas práticas e seu papel na dinâmica da situação de procura estudada, convém fazer uma descrição breve da sua jornada diária de

$52 \quad$ Para mais detalhes sobre as diferenças entre os tipos de plaqueiros e para uma reflexão mais focada nesse tipo de ocupação ver Cerqueira, (2000) e Vieira (2007). 
atividades $^{53}$. O dia de trabalho começa, para quase todos, às oito horas da manhã, quando chegam à agência e pegam a placa, com a qual descem para a rua. Lá sua função básica é divulgar vagas de trabalho. Ali na rua eles permanecem até por volta do meio dia, quando retornam à agência para almoçar. Normalmente levam a própria marmita, pois as agências não fornecem vale-refeição. Freqüentemente, ainda no horário de almoço, são solicitados a desempenhar funções complementares, que podem ser desenvolvidas tanto na parte interna da agência quanto na externa; são atividades de apoio à retaguarda das agências ou de office-boy. Por volta das quatorze horas, voltam para a rua, onde ficam até às dezesseis ou dezessete horas, horário em que a circulação de demandantes de trabalho já se encontra bem fraca. Cumprida a jornada diária na rua, eles retornam à agência para entregar a placa e ir embora, ou ajudar em alguma coisa, caso sejam solicitados, podendo permanecer em atividade de trabalho até ás dezoito ou dezenove horas, se necessário. A jornada de trabalho é pesada, as horas-extras não são remuneradas e atuação desse trabalhador é múltipla e polivalente, não se restringindo à veiculação de informações na rua. "A gente faz de tudo um pouco, não pode ter tempo ruim, trabalho é o que não falta. Eu sou plaqueiro, mas trabalho tanto na rua, quanto na agência", disse S. Fernando, que já foi metalúrgico, mas trabalha como plaqueiro há mais de 6 anos, sendo que há 4 anos na agencia em que se encontra atualmente .

A jornada semanal de trabalho é de segunda à sexta; as agências não operam aos sábados. Os pagamentos são feitos, na maioria dos casos, semanalmente, mas contando apenas os dias trabalhados; faltas e feriados não são remunerados. Tal remuneração mal chega a totalizar um salário mínimo e meio por mês. As relações de trabalho entre os plaqueiros e as agências de emprego são, na maioria dos casos, de natureza informal; poucos deles possuem registro em carteira. Porém, ao contrário do que poderia supor o senso comum, apesar de informais essas relações de trabalho são razoavelmente estáveis e duradouras, podendo durar anos. Um dos plaqueiros entrevistados estava a dezesseis anos trabalhando como plaqueiro em uma agência de emprego. Os relatos dizem que isso é comum para plaqueiros que trabalham para as agências, mas não para plaqueiros que trabalham para estabelecimentos que fazem e copiam currículos, compram e vendem ouro ou outros serviços, onde há muita rotatividade. Dentro da realidade daquela ocupação, trabalhar para as agências de emprego é a melhor opção, o que é almejado por muitos daqueles que trabalham como plaqueiros para outros estabelecimentos; é o que disse S. Vladimir, que já trabalhou como plaqueiro de variados tipos de estabelecimentos, inclusive para o comércio de compra e venda de ouro e que trabalhava naquele território há 3 anos.

53 Tal descrição tem como fonte os relatos dos plaqueiros que trabalham para as agências de emprego. 
Abaixo se apresenta um quadro onde se sistematizam as práticas e atividades dos plaqueiros entrevistados.

Quadro. 3.3.Práticas e atividades dos plaqueiros entrevistados

\begin{tabular}{|c|c|c|c|c|c|c|c|}
\hline Nome & $\begin{array}{c}\text { Recolhe } \\
\text { currícul } \\
\text { o na } \\
\text { rua? }\end{array}$ & $\begin{array}{c}\text { Faz pré- } \\
\text { seleção de } \\
\text { currículo na } \\
\text { rua? }\end{array}$ & $\begin{array}{c}\text { Exerce } \\
\text { outras } \\
\text { funções na } \\
\text { agência? } \\
\text { Quais? }\end{array}$ & $\begin{array}{c}\text { Aborda as } \\
\text { pessoas na } \\
\text { rua? }\end{array}$ & $\begin{array}{c}\text { Circula } \\
\text { ou fica } \\
\text { parado? }\end{array}$ & $\begin{array}{c}\text { Interage } \\
\text { com as } \\
\text { pessoas? } \\
\text { Conversa, } \\
\text { informações, } \\
\text { dicas? }\end{array}$ & $\begin{array}{c}\text { Aciona } \\
\text { contatos } \\
\text { pessoais ou } \\
\text { possui uma } \\
\text { clientela? }\end{array}$ \\
\hline Fernando & sim & sim & office-boy & sim & circula & sim & sim \\
\hline Vladimir & sim & não & não & sim & circula & sim & não \\
\hline João & não & não & não & não & parado & não & não \\
\hline Josivaldo & não & não & office-boy & não & parado & não & não \\
\hline Antônio & não & não & $\begin{array}{c}\text { office-boy } \\
\text { e triagem } \\
\text { de } \\
\text { currículos }\end{array}$ & não & parado & não & não \\
\hline Jorge & sim & não & office-boy & não & circula & sim & não \\
\hline Raimundo & sim & sim & $\begin{array}{c}\text { triagem de } \\
\text { currículos }\end{array}$ & não & parado & sim & sim \\
\hline
\end{tabular}

Fonte: Levantamento de campo, 2009.

Ainda no que diz respeito ao cotidiano, é importante registrar que o trabalhador que desenvolve sua atividade na rua tem a necessidade de consolidar um espaço e protegê-lo; há uma concorrência por espaço e visibilidade. Cerqueira (2000) descreve a existência de uma disputa de espaços acirrada e marcada por hostilidade que se travava entre plaqueiros e vendedores ambulantes no fim da década de 1990. Hoje, no entanto, os plaqueiros continuam de certa forma em competição, mas entre si, pois, para eles é imprescindível garantir a visibilidade e a eficácia da circulação de informações, o que essa profusão de veiculadores de informação pode atrapalhar. Por outro lado, como os ambulantes ilegais passaram a ser recentemente combatidos pelo poder público e os ambulantes licenciados estão fixados nas transversais à rua Barão de Itapetininga, esse antigo conflito pelo espaço perdeu relevância naquela dinâmica. Por outro lado, como será explorado logo a seguir, o conflito com outros atores, os fiscais da Sub-prefeitura da Sé, ganhou importância. Esse processo de competição por espaço configura um dos processos espaciais aludidos por Strauss (1979) e que já foi mencionado anteriormente.

Além de desempenharem funções na retaguarda operacional das agências (serviços de Office boy e triagem dos currículos), e distribuírem panfletos (acumulando a função de panfleteiros), esses trabalhadores multifuncionais podem acumular outras funções na própria rua, durante a veiculação das vagas, que os envolve mais ativamente no processo de captação e seleção de candidatos, e os faz 
ainda mais fundamentais à dinâmica de procura de trabalho ali constituída. Por isso, além da divisão básica entre os plaqueiros que trabalham para as agências e os que trabalham para outros estabelecimentos, a partir de agora os sub-classifico de acordo com sua atuação na situação de procura, entre i) divulgadores de vagas, ii) receptores de currículos e iii) captadores de candidatos.

\subsection{Divulgadores, receptores e captadores: funções, interações e performances}

Práticas, funções e performances diferenciam a atuação dos plaqueiros na situação de procura estudada. E essas diferentes atuações na rua se refletem diretamente na interação deles tanto com os demandantes de trabalho quanto com as agências de emprego.

A prática mais básica à atividade de plaqueiro de agências de emprego é a divulgação na rua de vagas de trabalho através de placas que podem ser tanto seguradas quanto vestidas. Aqueles que desempenham na rua apenas essa função básica são classificados aqui como divulgadores de vagas. João, Josivaldo e Antônio podem ser assim classificados. À divulgação das vagas através das placas pode se somar também a distribuição de panfletos, mas ainda assim são considerados divulgadores, dado que os panfletos podem divulgar tanto as agências de emprego quanto vagas de trabalho. Aqui o processo de interação com os demandantes na rua é, em primeiro lugar, visual e, complementarmente, verbal. O demandante olha as ofertas de trabalho expostas nas placas divulgadas pelo plaqueiro e, se houver interesse, se encaminha para agência que o plaqueiro representa e divulga, pois há na placa o nome e o endereço da mesma. A interação verbal, nesse caso, é geralmente fruto de perguntas e pedidos de informação dos demandantes, as quais são freqüentes, mas que propiciam apenas diálogos breves, principalmente nos dias e horários mais movimentados.

Além da função básica de divulgação, muitos plaqueiros somam também a tarefa de recolher os currículos dos candidatos na rua. Esses são chamados de receptores de currículos. Vladimir e Jorge se encaixam nesse grupo. Nesse caso, quando os demandantes têm interesse nas vagas divulgadas nas placas, entregam os seus currículos nas mãos do próprio plaqueiro, que pode simplesmente recolhe-los ou, e tal como muitas vezes é orientado pela agência, fazer uma prétriagem ali mesmo na rua. Assim, se após uma rápida olhada o plaqueiro percebe que o currículo recebido não se encaixa no que a agência quer, separa esse daqueles que se adequam melhor ao posto ou o devolve para o demandante, explicando o motivo. Eles guardam os currículos recolhidos e pré-selecionados em pastas de plástico ou caixas de papelão e os entregam nas agências no horário do almoço e no fim do expediente. 
Ao receberem os currículos dos candidatos, os plaqueiros assumem a linha de frente da agência, operando não só como a "cara" e a parte visível, mas também como parte de atendimento ao público, ainda que de tipo itinerante. Ao recolherem os currículos na rua, eles desempenham a mesma função que as recepcionistas que o fazem no interior das agências de emprego. Ao fazerem uma espécie de triagem, eles se envolvem numa parte fundamental do processo de intermediação de mão-de-obra, que é o processo de seleção. Essa prática de coleta e triagem de CV's na rua se torna mais comum á medida que as agências operam cada vez mais num ritmo de urgência em que cada minuto economizado no processo de recrutamento de candidatos é valioso; afora isso, muitas agências operam, parcial ou integralmente, com as portas fechadas ao público. Segundo observações ao longo dos últimos quatro anos é possível afirmar que essa prática aumentou consideravelmente. Esse processo que se dá na própria rua é uma forma de economizar tempo e dinheiro por parte das agências de emprego. E, do ponto de vista dos demandantes, essa prática também é vantajosa, pois economiza o tempo que eles levariam para chegar até à agência.

Os receptores de currículos mantém uma interação muito mais intensa e longa com os demandantes, pois além de informações sobre as vagas, os plaqueiros muitas vezes têm que até explicar para o demandante porque ele não se encaixa na vaga ou, ao contrário, tentar convencer alguém que não parece interessado nas vagas ofertadas a deixar seu currículo. Foi possível observar diversas cenas em que os plaqueiros interagiam com os demandantes, conferindo os dados de seus currículos, fazendo questionamentos sobre trabalhos anteriores, perguntando sobre experiência comprovada em carteira de trabalho e sobre pretensão salarial (tal como fazem as recepcionistas das agencias) e até mesmo oferecendo dicas aos demandantes. Ao coletar os CVs, eles mesmos os analisam e fazem uma pré-seleção dos que podem ser mais adequados às vagas ofertadas. Assim, a relação da pessoa à procura de trabalho com a agencia de intermediação é cada vez mais mediada pela interação com o plaqueiro. Vladimir disse:

“Quando eu pego a placa na agência, o pessoal já fala 'para essas vagas precisa de ensino médio
completo', 'para aquelas vagas precisa de tantos anos de experiência'. Então, se eu vejo no currículo que a
pessoa não tem a experiência que eles querem, e não vai se encaixar em nenhuma vaga que tem no
momento, eu já descarto. Não adianta, que lá em cima eles não vão olhar. Se dá tempo de devolver o
currículo pro cara eu até devolvo, ele pode deixar com outro plaqueiro ou aproveitar aquilo que ia acabar
virando lixo. Se eu sei que tem outro lugar que ta pegando gente com o perfil dele eu aviso, dou a dica.”

Porém, a coleta de currículos na rua não é permitida, pois configura atividade comercial em espaço público e só os vendedores ambulantes autorizados pela Prefeitura podem fazê-lo. Assim, tal como acontece com os camelôs, nos últimos meses as atividades dos plaqueiros têm sido mais intensamente fiscalizadas pelo poder público, através de fiscais da Subprefeitura da Sé. Essas 
práticas que eram toleradas tornaram-se alvo de preocupação da Subprefeitura no contexto de intensificação de ações do projeto "Cidade Limpa". Segundo as determinações de tal projeto municipal, os plaqueiros podem veicular as informações das placas que seguram ou vestem, porém não podem recolher nada que venha dos demandantes; coletar currículos fica expressamente proibido, sob pena de apreensão do material e multa à agência representada. Mas, na prática, a atividade de recolhimento de currículo continua existindo, mesmo proibida. Os fiscais da Subprefeitura só eventualmente aparecem para cumprir sua função e realizar eventuais apreensões, e há uma dispersão rápida dos plaqueiros que só muito raramente são flagrados pelos fiscais; banquinhos e currículos são rapidamente escondidos ao menor sinal de chegada dos fiscais da Subprefeitura e voltam à cena assim que eles vão embora. No dia-a-dia, seriam os policiais da Guarda Civil Metropolitana, esses sim presença constante no lugar, que deveriam reprimir essas práticas; entretanto, eles não fazem. Há uma relação baseada na camaradagem e na negociação entre os guardas e os plaqueiros ${ }^{54}$. "Eles [guardas] respeitam nosso trabalho, eles são gente boa", disse Fernando. O clima de medo e tensão, no entanto, é presente, pois os fiscais podem chegar a qualquer momento.

Desde então, esses plaqueiros receptores se sentem ameaçados, temem que a utilidade de sua ocupação seja diminuída, justamente quando haviam se tornado mais fundamentais ao funcionamento das agências. A sensação de revolta e desaprovação para com o poder público é total. Prefeito, Subprefeito da Sé e seus fiscais são alvos constantes de críticas.

Mas, o mais interessante é notar que os próprios demandantes também desaprovam essa pretensa mudança; dizem que é muito mais prático distribuir os currículos entre os plaqueiros na rua, pois essa estratégia lhes poupa tempo, como já adiantado. E mais que isso, algumas pessoas disseram que se sentem mais à vontade com essa prática do que com a prática usual de entrar nas agências, destacando o desconforto ou constrangimento que esse estabelecimento pode causar, referindo-se à violência simbólica imposta pela interação dentro da agência, a qual é superada na interação com o plaqueiro. Se a interação com a recepcionista ou com a selecionadora da agencia de emprego pode assustar o demandante via de regra inexperiente, sem códigos e com origem em segmentos mais pobres da população, a interação com o plaqueiro não. Ela teria a vantagem de

$54 \quad$ Foi possível presenciar uma situação em que tal camaradagem e possibilidade de negociação entre esses atores ficaram explícitas. Numa tarde de pouco movimento, chegou uma equipe grande de policiais da Guarda Metropolitana e, espalhados em duplas e trios pela rua, pediram para os plaqueiros guardarem temporariamente seus bancos e currículos, pois uma rede de televisão estava chegando para fazer uma reportagem sobre a Rua Barão de Itapetininga. O tom da abordagem dos policiais era totalmente amigável e sugeria um pedido e não uma ordem. Ademais, assim que a reportagem acabasse, tudo poderia "voltar ao normal". 
evitar a violência simbólica contida na encenação do "bom demandante de trabalho". A máscara que se faz necessária quando se passa da porta da agência para dentro, parece ser muito mais maleável da porta da agência para fora. A negociação da representação de si na interação com o plaqueiro é menos assimétrica e mais informal do que a que se faz na interação com os funcionários especializados, com os profissionais da intermediação. Assim, disse Jorge:

“Os meninos não tem vergonha de perguntar pra gente [plaqueiros] se o trabalho é bom, se o salário é bom, porque essas coisas nem sempre estão escritas na placa. Eles perguntam mesmo, numa boa. A gente bate um papo, mas eu não minto; quando é temporário, quando não é registrado eu falo; a pessoa tem que saber, daí ela avalia se vale à pena. E tá certo, é normal querer saber se o salário é bom, se é registrado. Mas lá dentro da agência, eles não perguntam, não."

E, mais que peças-chave na interação entre agências e demandantes, para as vagas de trabalho que estão em jogo ali na rua, alguns plaqueiros estão habilitados a acionar rapidamente tanto sua "clientela" (demandantes que se tornam conhecidos por freqüentarem a região) quanto seus próprios contatos pessoais. São os plaqueiros captadores de candidatos, como Fernando e Raimundo. Eles teriam, conforme observações e relatos, uma teia de contatos pessoais e até mesmo uma "clientela", composta por candidatos que procuram com freqüência trabalho no Centro; isso lhes permite alcançar, com rapidez, um bom número de candidatos para preencher uma determinada demanda, o que é vital para o bom desempenho das pequenas agências privadas, onde o senso de urgência dá o tom. É ilustrativo desse aspecto o trecho de um depoimento de uma funcionária de agência entrevistada por Cerqueira (2000):

"O que acontece, atualmente, é que o cliente liga para nossa consultoria pedindo 20 pessoas para preencherem, vamos supor, as vagas de caixa para ontem. Os plaqueiros nos ajudam muito nessas vagas que temos que fechar de um dia para o outro, porque eles, inclusive, muitas vezes já têm contato com as pessoas, têm mesmo uma clientela e já são super conhecidos na rua."(apud Cerqueira, 2000, pp. 38. Grifos meus)

O plaqueiro pode acionar também seus contatos pessoais, amigos e conhecidos, tornando-se um canal de captação e recrutamento que pode ser duplamente vantajoso. Eis o depoimento de Fernando:

“Tem umas meninas, por exemplo, que estão sempre procurando por aqui. Eu sei que elas têm experiência com vendas, com call center. Se eu sei que agencia tá precisando desse tipo de menina, eu já procuro elas por aqui, se encontro uma já falo para ela avisar as outras. A mesma coisa pro pessoal de obras, tem uns caras que de tempos em tempos estão por aqui e acabam até virando nosso amigos. Se a agencia ta precisando de pedreiro, eu já faço a informação chegar neles correndo. Tem uns que até me deixam um telefone, um cartão."

A rapidez na localização de candidatos seria uma vantagem, e a indicação de pessoas conhecidas que, teoricamente, portariam o atributo distintivo do capital confiança (são, conhecidas, daí “serem de confiança”), seria a outra. É possível perceber que as agências de emprego, formas 
usualmente entendidas como mercantis e, por isso mesmo, institucionalizadas e impessoais de intermediação de mão-de-obra, operam, como tudo na vida econômica, de forma mais complexa, utilizando-se dos serviços dos plaqueiros para também contar com os mecanismos pessoais de recrutamento de trabalho, que podem ser, e na maioria das vezes são, mais eficientes ${ }^{55}$. Fernando disse também que leva as informações das vagas ofertadas na agência para sua família e para sua vizinhança. Ele disse que já indicou suas sobrinhas para vagas de vendedoras e vários vizinhos para vagas diversas. Raimundo também indica vizinhos e parentes para concorrer às vagas que ele próprio divulga. "É o pessoal da agência mesmo que pergunta se eu não conheço ninguém, não sou eu que ando empurrando meus amigos, não", disse Raimundo se explicando. Para as agências privadas, os plaqueiros também podem funcionar como eficazes captadores de candidatos.

Pensando nas agências como estabelecimentos que têm duas tarefas básicas, captar vagas de trabalho nas empresas-cliente e captar candidatos para essas vagas, esses plaqueiros captadores assumem lugar central na frente voltada aos candidatos. Aqui eles não apenas servem como peça de ligação entre agências e demandantes, mas podem buscar ativamente candidatos para vagas específicas. Nesses casos em que os plaqueiros acionam suas redes sociais como meio de recrutamento e desenvolvem estratégias de abordagem, estabelecimento e manutenção de contatos com os demandantes, a "clientela", poder-se-ia dizer que esse personagem contribui ativamente no delineamento e dinâmica da situação de procura trabalho, interferindo nela e no resultado final do processo de convergência entre uma vaga de trabalho e um demandante.

Dos plaqueiros entrevistados, três deles são apenas "divulgadores de vagas", dois deles são, além de divulgadores, também "receptores de currículos" e outros dois acumulam à essas funções a de "captadores de candidatos". Não se quer sugerir a importância quantitativa das diferentes linhas de atividades, mas assinalar a diversidade existente e os distintos impactos sobre a dinâmica da situação de procura que cada uma dessas formas é capaz de produzir.

Finalizando, vimos até aqui que os plaqueiros são personagens típicos daquele espaço e daquela situação social; e que eles são uma conexão crucial entre as agências e o espaço da rua, tanto quanto entre as agências e os demandantes. A dinâmica de divulgação de vagas e de captação de candidatos está, para muitas agencias de emprego, totalmente assentada na atuação dos plaqueiros, razão pela qual os destacamos para uma descrição mais acurada, independente daquela que foi inicialmente

55 A eficiência dos mecanismos pessoais, destacada por Granovetter em seu clássico trabalho de 1974 foi também encontrada como resultado do survey realizado em 2004 na região metropolitana de São Paulo com demandantes de trabalho (Guimarães, 2007-a e 2009). 
feita com respeito às agências e antecedendo a que se fará em seguida com respeito ao demandante de trabalho.

\section{Os demandantes de trabalho}

Os demandantes de trabalho constituem o mais numeroso e variado grupo de atores que transitam naquele território e constituem a situação de procura de trabalho. Mais que isso, eles são, na verdade, o objeto primeiro do interesse de todos, já que são os principais clientes dos mercados que ali operam, vale dizer, tanto do mercado de intermediação de mão-de-obra, quanto do "mercado de condutas".

Entretanto, antes de prosseguir é necessário repetir uma observação já anteriormente formulada e que é importante para bem abordarmos o tema, assumindo o que distancia (e não somente o que aproxima) os campos do desemprego e da procura de trabalho: nem todo demandante de trabalho é necessariamente um desempregado, conquanto, em São Paulo, e nesse momento, para a grande maioria dos casos dos que afluem ao Centro essa relação seja verdadeira. Tê-lo em mente é importante pois é um dos eixos de explicação para a diversidade de conduta na situação de procura: ali, há os que nunca trabalharam e estão em busca de um primeiro emprego (e nesse sentido almejam deixar o que tecnicamente se chama situação de inatividade); há os que perderam o emprego e estão em busca de um novo trabalho, estando desocupados ( o que tecnicamente configura a situação de desemprego), e há os que, tendo trabalho, estão em busca de um trabalho de melhor qualidade (o que tecnicamente nos faria classifica-los como ocupados). Essa diferença de situação vis-à-vis o mercado de trabalho não somente é prenhe de consequiências com respeito à modalidade de conduta na procura, como é decisiva para diferenciar os três principais tipos de trabalhadores que buscam trabalhos em agências de emprego, tal como documentada em cuidadosa analise quantitativa, usando os dados do survey "À procura de trabalho" (Guimarães e Melo, apud Guimarães 2009).

Diferentemente dos outros atores, que têm uma atuação diária, estável, duradoura e repetitiva naquela situação, os demandantes de trabalho são transitórios, atuam nela apenas por algumas horas, ou até mesmo, por alguns minutos e estão ali em constante movimento de rotatividade. No entanto, o demandante de trabalho é aquele que está conectado a todos os outros atores e que, ao mesmo tempo, os conecta entre si.

É esse o ator que tem como objetivo encontrar um trabalho e que vive a experiência social da procura de trabalho, da qual aquela situação de procura é parte. Os outros atores da situação de 
procura trabalho têm outros objetivos, que se resumem na tarefa de tornar possível a convergência entre uma vaga e um trabalhador. Dentro de uma situação social, a atuação de todos os atores é igualmente relevante para a constituição de sua dinâmica, e um dos objetivos desse trabalho é justamente o de reforçar essa idéia através da argumentação da pertinência da situação social como unidade de análise.

Como um dos objetivos dessa investigação é entender mais sobre a experiência da procura, tal como vivida pelos demandantes, no capítulo 4 ele será o personagem privilegiado da análise. Ali buscaremos entender não apenas elementos de sua atuação na situação de procura, mas compreender como essa vivência situada está conectada com outras dimensões sociais da vida do demandante. No capítulo seguinte apresentaremos em detalhe os demandantes entrevistados, levando em conta suas características sociais e seus discursos para compreender os condicionantes da experiência de procura. Na presente sessão, no entanto, focaremos a atuação e performance desse ator na situação investigada. Cabe, porém, iniciar com uma apresentação das características gerais dos demandantes que acorrem àquele espaço de procura. Na seqüência apresentamos uma descrição detalhada de sua atuação e interação com os outros atores daquele território. Ao longo de todo o processo de pesquisa, desde a fase exploratória, foram abordados e escutados mais de 40 demandantes de trabalho. Porém, foram entrevistados a partir de um roteiro comum de questões exatamente 24 demandantes. As interpretações e análises foram feitas a partir desses 24 entrevistas, sem, contudo, descartar as informações e discursos coletados na fase exploratória da pesquisa.

\subsection{Perfil e características gerais}

Recente estudo sobre perfil dos demandantes de trabalho em instituições de intermediação de mão-de-obra (tanto públicas quanto privadas) da região metropolitana de São Paulo, (Guimarães e Melo, 2008) tomou por base um survey amostral e revelou que o a clientela mais importante dessas instituições de intermediação é formada por trabalhadores jovens, muito mais freqüentes nessa amostra do que na média da força de trabalho em procura de emprego em São Paulo. A sua escolaridade também os tipifica, por estar bem acima da média da população economicamente ativa da metrópole paulista. Nenhuma diferença significativa na participação por sexo parece caracterizar este grupo, tendo-se em conta ainda os dados do survey “À procura de trabalho". Entretanto, do ponto de vista da composição racial, pretos e pardos pareciam sub-representados nos dados do survey se comparados a seu peso entre os indivíduos ativos em São Paulo. 
Os achados desse estudo vão ao encontro do que foi observado no curso da nossa pesquisa na região da Barão de Itapetininga e adjacências. Naquele território, homens e mulheres parecem estar em igual proporção no grupo dos demandantes, assim como parece haver uma parcela muito pequena de negros. Na Barão, os demandantes também são majoritariamente jovens. Ainda que não se tenha qualquer pretensão de representatividade, pode-se notar que o perfil do nosso grupo de entrevistados preserva a diversidade que caracteriza o conjunto dos demandantes em agências. Assim, dos 24 entrevistados, 13 eram homens e 11 mulheres. A maioria dos demandantes entrevistados se encaixa na categoria de jovens ou jovens adultos. Três deles tinham menos de 18 anos, 17 deles possuíam idades entre 18 a 30 anos e apenas quatro dos entrevistados tinham mais de 30 anos.

A escolaridade do demandante que acorre às agências do Centro, na maioria dos casos, também parece ter como piso o nível médio completo, segundo os levantamentos de campo e Tartuce (2007, 2007-b). Dentre os nossos os 24 entrevistados, 16 possuem nível médio completo ou incompleto e 5 deles possuem escolaridade de nível superior incompleto.

A observação de algumas características como escolaridade dos pais, local de moradia, tipo de instituição de estudo (privada/pública), profissão, ocupação anterior, ocupação almejada, entre outras, nos levam a concluir, assim como Tartuce (2007, 2007-b), que a grande maioria dos demandantes que frequientam as agências do Centro provém de uma origem social em grupos de mais baixa renda. É certo que, pelos atributos simbólicos e custos materiais que a procura de trabalho em instituições de intermediação requer (roupa adequada, transporte, alimentação, cópia de currículos, fotos, etc.) pode-se dizer que eles não pertencem a uma condição de extrema pobreza, mas se situam em setores de uma baixa classe média. A origem social desses candidatos a trabalho parece estar articulada ao tipo de vaga que se oferece ali. Demandantes de poder aquisitivo mais alto buscam trabalho, predominantemente através da internet (Hirano, 2007; Georges e Janequine, 2007; Tartuce, 2007, 2007-b; Vieira, 2007) e é muito difícil encontrá-los em clusters de intermediação de mão-de-obra, como o da Rua Barão de Itapetininga, até mesmo porque as vagas ofertadas ali são de baixa qualidade (exigem pouca qualificação e experiência e oferecem remuneração baixa).

Todos os entrevistados estudaram em escolas públicas. Quando graduados ou graduandos no ensino superior, a instituição cursada era particular e pouco reconhecida ou valorizada. Os estudantes de ensino superior que estavam procurando trabalho não buscavam necessariamente uma ocupação relacionada à sua área de formação ou estudo. Quatro dos 24 entrevistados eram primodemandantes, ou seja, buscavam seu primeiro emprego. 
Tartuce (2007, 2007-b) entrevistou jovens em procura de trabalho a partir de dois locais/espaços diferentes para captar os significados da transição escola-trabalho. Um desses locais foi o CIEE (maior centro de intermediação de estágios do Brasil) e outro foi justamente o cluster de intermediação de mão-de-obra do Centro: a Barão de Itapetininga. Um dos achados mais interessantes de sua investigação foi o de que os jovens que procuram ocupação através desses dois tipos de espaço e estratégias são muito diferentes do ponto de vista sócio-econômico: os que procuram estágios no CIEE têm origem social mais privilegiada e, via de regra, maior nível de escolaridade do que aqueles que procuram no cluster do Centro. Ademais, mesmo quando a origem sócio-econômica se assemelha, há um elemento determinante que os diferencia: o tipo de trabalho procurado. A pesquisa de Tartuce (2007-b) pôde comprovar que o jovem em busca de trabalho no Centro, diferentemente dos que procuram estágio no CIEE, não demandam empregos de qualidade, no seu campo de formação ou condizente com suas aspirações quanto ao futuro profissional; almejam, antes de mais nada, encontrar um trabalho que lhes permita suprir as necessidades materiais prementes.

A presente pesquisa corrobora esses achados de Tartuce. Vimos, em nosso trabalho de campo, que o principal fator que move os demandantes entrevistados até o Centro para procurar trabalho é a urgência material, aliada à idéia, amplamente difundida, de que naquele espaço é "fácil arrumar um trabalho". Essa facilidade, porém, só existe para os postos pouco qualificados e mal remunerados, características que já estão implícitas na idéia de "facilidade", pois, os demandantes sabem que não se acha "bons trabalhos" com facilidade.

As vagas nas áreas de vendas e serviços são as mais procuradas, até porque também se constituem nas vagas que ali são mais ofertadas. Quando a pergunta foi "qual tipo de ocupação você está procurando aqui?", as respostas mais freqüentes foram vendedor e operador de telemarketing, mas limpeza, serviços gerais, vigilante, auxiliar de escritório e recepcionista também foram ocupações bastante citadas. Uma observação curiosa, entretanto, é que, em resposta a essa pergunta, os entrevistados tendiam a citar mais de um tipo de ocupação, por vezes até muitos tipos de ocupação, como se ilustra na tabela abaixo. Isso porque o objetivo é ter vários alvos para aumentar as chances de obtenção de emprego dada a premência, antes que focalizar num alvo, numa estratégia seletiva e profissionalmente orientada.

Outra questão importante é a forma como o demandante tomou conhecimento daquele espaço. É interessante notar que foram os contatos pessoais são aqueles mais citados como fornecedores das informações que levaram os demandantes até aquele espaço. Sete entrevistados chegaram até lá 
através de informações dadas por parentes, 18 deles por informações provenientes de amigos, conhecidos ou namorado (a), 3 deles através da internet, 2 através da televisão e 1 descobriu o local sozinho, passando por aquela rua.

Quais os motivos que levam os demandantes até àquele espaço da cidade e não a outro qualquer é também uma questão relevante para se entender um pouco mais sobre a representação que eles têm sobre aquele espaço. As respostas elaboradas pelos demandantes a essa questão foram agrupadas em categorias, de forma que se pode dizer que as três razões que mais mobilizaram os demandantes a se deslocar até o Centro da cidade, vindos muitas vezes de muito longe dali, foram: i) a enorme concentração de agências, que facilita a procura e maximiza as chances de se obter sucesso, ii) a fama de que o lugar possibilita obtenção fácil de trabalho e o iii) acesso facilitado ao local por meios públicos e variados de transporte, destacado o metrô. Com efeito, vindos das mais variadas e longínquas regiões da metrópole, os demandantes, em sua esmagadora maioria, fazem esse percurso através de um ou vários meios de transporte público. Dos 24 entrevistados, 17 chegaram até o Centro por transporte público, 4 foram de carona (carro), 1 foi com motocicleta própria, 1 com motocicleta emprestada e 1 a pé.

Esses achados reforçam a idéia de que a operação das agências de emprego em clusters é eficiente na captação de candidatos. Podemos interpretar também que a relação do demandante com aquele espaço é motivada e mediada pela expectativa de arrumar um trabalho com facilidade e rapidez (e não necessariamente um trabalho de qualidade, motivo citado apenas por duas pessoas), reforçando a idéia apresentada acima de que uma das principais características do demandante de trabalho que acorre às agências do Centro é a necessidade financeira expressa na urgência da procura e na disponibilidade em aceitar trabalhos pouco qualificados e mal remunerados, mesmo que inferiores à sua ocupação anterior ou que à sua expectativa inicial.

Descrito o perfil geral dos demandantes que acorrem às agências privadas de intermediação com base em trabalho quantitativo (Guimarães e Melo, 2008) e algumas características dos demandantes entrevistados nesse estudo ${ }^{56}$ - assim como as motivações que os levaram até aquele espaço e as expectativas que os guiam naquela situação de procura - passemos à sua atuação e

\footnotetext{
${ }^{56}$ Esse sub-item não pretende sugerir uma caracterização geral de perfil dos demandantes que acorrem ao Centro, pois os dados colhidos não têm força quantitativa para isso, já que o que aqui importava era não a generabilidade do perfil, mas a riqueza dos discursos. Aqui se busca, antes, ressaltar somente que o grupo dos demandantes entrevistados preserva, de alguma forma, a diversidade das características daqueles que acorrem às agências privadas de emprego, encontradas no estudo quantitativo acima referido. Busca-se também introduzir algumas das características dos demandantes entrevistados, as quais serão tratadas em detalhe no capítulo seguinte.
} 
performance na situação propriamente dita. Aqui importa o processo de procura, suas práticas, gestos e interações com os outros atores e usos do espaço.

\subsection{0 demandante na situação: atuação, interação e conduta}

O processo que praticamente todos os demandantes enfrentam na tarefa de procurar trabalho naquele território é parecido. Para começar o processo de procura é preciso ter em mãos, no mínimo, um número grande de cópias de currículo nas mãos. Essas cópias podem ser trazidas de casa ou feitas lá em algum estabelecimento especializado nisso. O próprio currículo também pode ser feito lá, em algum desses estabelecimentos, como já adiantamos, mas não necessariamente. Com as cópias em mãos, geralmente armazenadas em pasta, o demandante está pronto para começar sua peregrinação pelas diversas agências da região. Para que essa tarefa seja tão eficiente quanto se deseja e nenhuma agência escape, pode-se adquirir um "guia das agências da região", vendido na rua por vendedores ambulantes ou nos estabelecimentos que fazem e copiam currículos. Esse guia, no entanto, não é, como o currículo, instrumento indispensável. A grande maioria dos demandantes chega àquele lugar com a intenção de fazer esse circuito entre numerosas agências, e não para visitar uma ou outra agência específica. Para os demandantes, o principal atrativo daquele espaço é a grande concentração de agências, que passa a ser explorada através de uma longa peregrinação em edifícios e galerias diversas.

Antes de explorar esse universo das agências propriamente ditas, o demandante, ao chegar naquela rua, se depara com uma infinidade de anúncios de vagas de trabalho colados nos postes, nos muros, no chão e veiculadas pelos plaqueiros. Então, o processo de procura começa ali mesmo na rua, onde os demandantes olham esses anúncios e procuram identificar as vagas que lhes interessa ou nas quais ele se encaixa. Quando a vaga que despertou interesse está veiculada num anúncio de papel colado em algum lugar, o que o demandante faz é anotar o endereço ou contato do estabelecimento que está ofertando aquele posto. Se o interesse surge de uma vaga veiculada por um plaqueiro, o processo pode ser diferente. Caso o plaqueiro seja apenas um divulgador de vagas, o demandante pode anotar ou memorizar o nome da agência que ele representa, para depois procurála. Já se o plaqueiro for, além de um divulgador, um receptor de currículos, o demandante pode deixar o seu currículo com esse profissional, e fica dispensado de deixar outra cópia na recepção da agência que o plaqueiro representa. O plaqueiro pode simplesmente recolher o currículo ou então fazer uma breve análise, selecionado-o ou não. Nesse caso, a interação entre demandante e plaqueiro é mais intensa e muito verbal, e há espaço para perguntas, para pedidos de informações por parte dos 
demandantes e até para negociações. Se o demandante não possui algum dos pré-requisitos exigidos para a vaga, pode tentar convencer o plaqueiro a levar o seu currículo e coloca-lo junto dos currículos pré-selecionados por ele, alegando possuir alguma qualidade que o torne adequado à vaga. Por exemplo, um demandante pode alegar que não possui o tempo de experiência exigido, mas que possui cursos na área de atuação da vaga, insistindo para o plaqueiro separar seu currículo e deixando aberta uma possibilidade de tê-lo analisado pela agência, o que nem aconteceria se o plaqueiro o descartasse. Esse tipo de negociação explícita foi observada e relatada, tanto por plaqueiros quanto por demandantes. A interação entre demandantes e plaqueiros é descontraída e amistosa, ás vezes mais longa, às vezes mais curta, dependendo do movimento e do número de demandantes que esteja ao redor do mesmo plaqueiro.

Após essa busca preliminar na rua, o candidato passa a se dirigir para as agências de emprego. Os demandantes entram nos edifícios e galerias e buscam alcançar o maior número de agências possível, para deixar seu currículo na recepção de cada uma. No caso dos edifícios, os demandantes chegam até às agências através de escadas ou elevadores. Nos horários mais movimentados do dia é comum formarem-se pequenas filas ou aglomerações na recepção das agências, porém essas se dispersam rapidamente. Já na porta do edifício Rio Branco, onde a entrada é controlada e limitada a pequenos grupos de pessoas e a horários limitados do dia, a fila se forma na própria rua e não se desfaz rapidamente. É possível um demandante ficar até uma hora nessa fila. Esse é o momento onde a interação entre os próprios demandantes é mais facilmente observada. De pé, na fila, os demandantes iniciam conversas que podem durar até que chegue a vez de se entrar no prédio, ou seja, vários minutos. Os assuntos giram, como era de se esperar, ao redor do tema procura de trabalho: dicas, informações e desabafos dão o tom dessas conversas. Há, inclusive, um tom de solidariedade e cooperação, pois estão partilhando a mesma condição de demandante, com suas dificuldades e desafios. Nesse tipo de interação que ocorre nas filas ou na recepção de uma agencia, não é possível notar um clima de competição entre os demandantes, pois, a rigor, ainda não são concorrentes, já que nesse processo de distribuição de currículos não estão disputando nenhuma vaga específica. Esse clima de solidariedade perde lugar para o de competição quando se encontram disputando as mesmas vagas em dinâmicas de grupo ou na recepção de uma agência, no aguardo de sua entrevista com a selecionadora, como colocado anteriormente, quando fizemos a descrição dos processos seletivos transcorridos nas agencias. 


\section{Figura 3.5. Demandantes de trabalho em fila}

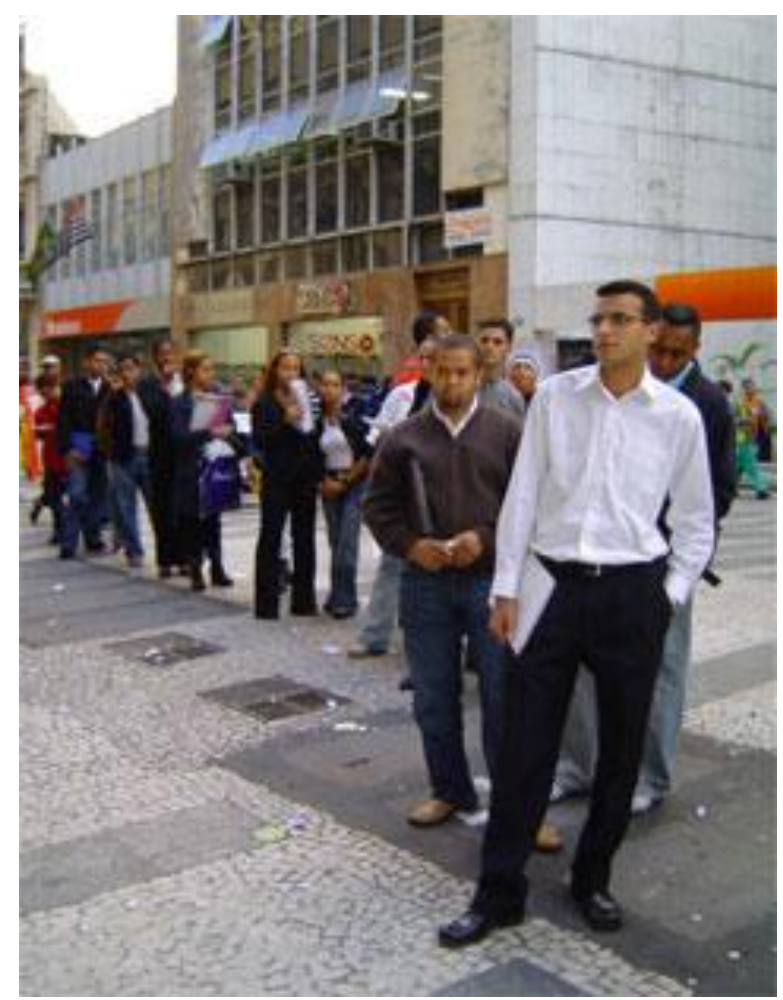

Fonte: Site do Centro de Estudos da Metrópole (www.centrodametropole.org.br/divercidade/numero4)

Já dentro das agências, a interação com os funcionários pode ser bem breve, mas, na maioria dos casos, as recepcionistas são orientadas a, no mínimo, conferir rapidamente alguns dados dos currículos na frente dos demandantes, como desenvolvido em item anterior. Finalizada a interação entre o demandante e a recepcionista, ele deixa aquela recepção e procura outra agência onde possa entregar o seu currículo e repetir o mesmo processo. Em alguns casos, após a checagem rápida do currículo, os demandantes podem ser convidados para participar de um processo seletivo, recebendo também as informações sobre data, hora e local de tal processo, que pode até ser realizado naquele mesmo momento. Nesse caso, o demandante permanece na agência e participa de algum tipo de avaliação, seja um exame escrito, seja uma entrevista com selecionador, ou ambos. A resposta para a aprovação ou não do candidato naquele processo pode até ser instantânea.

A interação entre demandante e selecionador é fundamental no processo de procura, como exposto anteriormente. Essa interação é aquele que provoca mais constrangimento nos demandantes, pois é orientada por um processo de julgamento e avaliação e está assentada em uma desigualdade muito grande de papéis e de status. Além disso, é exatamente no decorrer dessa interação que a conduta do bom demandante de trabalho precisa ser exemplarmente encenada. Aqui a manutenção 
do personagem com seu discurso adequado (aí compreendida a manipulação correta das informações) e suas práticas e gestos adequados é decisiva para o sucesso do processo de procura. A pressão imposta por essa interação no desempenho do demandante causa medo e insegurança nos mesmos, segundo seus relatos. Há, ainda, outro elemento que pode provocar ruído nessa interação, que é a falta de compreensão do demandante das expectativas que o selecionador tem a respeito dele, o que dificulta a encenação adequada do personagem, possibilitando a manipulação incorreta das informações, por exemplo. Se o demandante não partilha ou conhece os códigos da conduta que o selecionador espera dele, pode ser julgado como "despreparado", o que, de fato, acontece, como apontamos anteriormente quando caracterizamos os selecionadores, seus discursos e suas práticas . O conhecimento dos códigos e a capacidade de encená-los na forma de uma conduta convincente é determinante da interação dos demandantes nas interações com os funcionários das agencias e do resultado dos processos seletivos.

Mesmo que o demandante não participe de nenhum processo seletivo e apenas deixe seus currículos com as recepcionistas, o percurso completo entre todas as agências pode demorar horas. Entre tirar cópias de currículo, olhar anúncios na rua e distribuir currículos nas mais de sessenta agências da região, pode-se demorar mais de um período do dia; assim, é freqüente que as pessoas cheguem de manhã e fiquem até parte da tarde. Até porque outros serviços, como os apresentados em item anterior desse capítulo, podem ser, e comumente são, utilizados pelos demandantes antes, durante ou mesmo após essa peregrinação entre as agências, estendendo o tempo de permanência naquele local.

O maior fluxo dos demandantes é no começo da semana (segunda e terça são os dias mais lotados) e no período da manhã. O movimento de demandantes na rua começa por volta das oito horas da manhã, quando as agências abrem suas portas e os plaqueiros vão para as ruas e termina por volta das dezessete horas. No horário de almoço (12 horas e 13h30min horas) o movimento de demandantes se dispersa porque os plaqueiros deixam a rua para cumprir o seu próprio horário de almoço e grande parte das agências fecha as portas nesse período. Esse é um momento em que as lan houses e as copiadoras ficam cheias, sem falar, é claro, nos restaurantes e lanchonetes da região.

Nos estabelecimentos que oferecem serviços correlatos à procura, os demandantes interagem entre si, e, principalmente, com seus funcionários. É interessante notar que aqui a interação é diferente daquela se estabelece com os funcionários das agências. Em primeiro lugar, porque essa é uma relação exclusivamente mercantil, o que não é verdade para a relação do demandante com a agência. Os demandantes não são clientes das agencias de emprego, e sim as empresas contratantes. 
Os demandantes não são vistos como clientes pelas agencias, mas sim por esses estabelecimentos, que os tratam como tal. Ademais, outra característica interessante dessa interação é que nela o demandante não precisa encarnar o personagem do "bom demandante de trabalho", como nas agências. Isso porque ali ele não demanda um trabalho, mas um serviço, e esses serviços têm o objetivo de justamente dota-lo de recursos e instrumentos necessários a essa conduta que será encenada fora desses estabelecimentos. A interação entre um demandante e um funcionário de algum estabelecimento do "mercado de condutas" está baseada na expressão e verbalização das necessidades e dificuldades envolvidas na constituição desse personagem, nas quais os serviços devem atuar. Essas interações são revestidas de um caráter mais colaborativo, no qual os funcionários devem dar a devida assessoria aos clientes, os demandantes. Porém, essa relação pode ser conflituosa, como mostramos anteriormente.

$\mathrm{Na}$ constituição do personagem de demandante, a roupa é um elemento de considerável importância. Os trajes dos demandantes podem, obviamente, variar, mas há uma tendência ao uso de calças compridas, tanto para homens quanto para mulheres; de tênis e sapatos fechados para homens, e sapatos ou sandálias, preferencialmente de salto, para mulheres. $\mathrm{O}$ uso de camisetas sem mangas é freqüente nos dias quentes, mas shorts, vestidos e saias curtas não são comuns, assim como os chinelos de borracha. Cores muito fortes ou a mistura de cores também não são usuais. Os trajes não são formais e o que impera ali é o básico "calça jeans e camiseta"; às vezes uma camisa social, porém, como sugerem os relatos, há uma preocupação em escolher a melhor calça e a melhor camiseta para esse tipo de ocasião, como pode ser percebido pelos relatos:

\footnotetext{
"Eu nunca sei que roupa usar para procurar emprego. Para participar de uma entrevista então, nem se fale... Eu já deixo uma roupa meio separada pra isso. Tem uma calça mais social que eu uso sempre que eu vou procurar trabalho, nem fico usando em outras ocasiões pra não estragar." (Thiago, 19 anos).

"Tem gente que fala que para procurar trabalho não pode sandália ou sapato aberto, tem gente que fala que tem que usar calça social. Eu acho que é exagero. Aqui o pessoal se veste mais descontraído. Para entrevista tem que se arrumar mais, mas para distribuir currículo não precisa tanto. Mas acho tem que estar com uma roupa nova, limpa, eu to de calça jeans e blusa, mas elas são novinhas. Essa blusa é uma das que eu mais gosto e acho boa para procurar trabalho porque ela parece séria, comportada, não é uma blusa decotada, por exemplo." (Silvana, 30 anos)
}

Há, portanto, por parte dos demandantes uma preocupação constante com a aparência e com a limpeza, com o objetivo de fazer a melhor figuração possível e adequar a própria imagem de si à imagem de um bom candidato, tal como esta é socialmente representada. Porém, nem sempre os demandantes sabem qual o tipo de roupa é esperado que eles vistam nessa situação; as selecionadoras reclamam que muitas pessoas fazem uso do vestuário inadequado, como roupas curtas, decotadas, sujas e informais. Essa questão será retomada no capítulo a seguir. Por ora, é 
importante registrar que, antes de partir para a procura propriamente dita, às vezes é necessário completar a imagem do "bom demandante" retocando a maquiagem ou substituindo algum item do vestuário que não esteja adequado. Uma das informantes, Ângela, contou que tinha esperado a loja de calçados abrir para poder comprar uma "sandália decente", nas palavras dela, com a intenção de tornar-se mais apresentável ao mercado de trabalho, já que a dela estava, ela disse, "gasta e velha". Um rapaz, com quem conversei na fase exploratória da pesquisa, contou que precisou comprar uma camiseta nova, pois a sua sujou logo no começo do dia de procura. Carmem, uma senhora entrevistada, substituiu o chinelo que calçava pelo sapato fechado que trazia na bolsa, pois para o longo trajeto de trem e ônibus o chinelo era mais adequado, enquanto que, para procurar trabalho, ela julgava necessário o sapato fechado. Mas, apesar de ter o caráter de preparação, todo esse processo já faz parte da experiência da procura, o qual, na verdade, começa bem antes de o demandante sair de sua casa. Todo o processo de juntar informações sobre o local para onde ir, o trajeto a ser feito até lá, a escolha da roupa, do calçado e da bolsa, a composição do currículo, a coleta de dicas de parentes e amigos, tudo isso constitui também a experiência de procura de trabalho e é anterior ao momento de pisar naquele território e atuar naquela situação.

Ademais, a constituição da conduta do demandante de trabalho é coletiva, não só porque é orientada por valores coletivamente reconhecidos, mas também porque ao redor de cada demandante de trabalho, há, como vimos antes, um conjunto de pessoas e serviços que pretendem torná-lo um "verdadeiro" demandante de trabalho ou demandante de trabalho "de sucesso". Assim, além dos processos em jogo no "mercado de condutas", a construção das práticas e dos discursos que as pessoas colocam em cena no momento da procura de trabalho passa também, e fortemente, por um conjunto de relações exteriores ao mercado de trabalho, ao mercado de intermediação de mão de obra e ao mercado de condutas. A família e os amigos atuam intensamente nesse processo. O que se quer dizer é que as relações pessoais do demandante podem atuar não só através de informações e indicações a vagas de trabalho, o que nós sabemos que é o método mais eficiente de obtenção (Granovetter, 1974, Guimarães, 2009) mas também agem sobre a construção da conduta de demandante que será desenvolvida no processo de procura. Essa ação se dá sob a forma de conselhos, ensinamentos, advertências, dicas e truques para que se tenha o desempenho esperado, além de uma série de favores. A companhia dos amigos e parentes durante o processo de procura também é recorrente e dá apoio emocional nessa que é uma situação de vulnerabilidade ${ }^{57}$. É muito comum que mães acompanhem seus filhos ou mesmo que filhos acompanhem os pais e mães, como

57 Tartuce $(2007,2007-b)$ também o documentou em seu trabalho de campo. 
foi possível flagrar essa situação no trabalho de campo. Sair para procurar trabalho com os amigos que também estão desempregados é freqüente entre os jovens, situação também observada e narrada pelos entrevistados. A experiência da procura é coletivamente partilhada e a construção da conduta também, como será explorado no capítulo a seguir. Aqui nesse capítulo, no entanto, apresentou-se essa conduta tal como uma conduta situada, construída a partir das regras da situação (e suas possíveis negociações e re-interpretações) e das interações com os outros atores.

\section{A situação de procura. Considerações finais}

A título de finalização, cabe uma tentativa de amarrar idéias que ficaram dispersas ao longo do capítulo, sem esgotá-las e chamando a atenção para o fato de que essas são algumas entre as várias formas possíveis de interpretação da dinâmica social investigada. Influenciadas por um olhar interpretativo, essas possíveis leituras acabam ressaltando alguns aspectos em detrimento de outros, como acontece em qualquer tentativa de análise, sempre parcial. Aqui há uma tentativa de explicitar como a situação de procura estudada é pautada, em sua constituição, pelos usos do espaço, pela interação entre os atores, pelos códigos que pautam as condutas situadas e pela relação daquela realidade micro-sociológica com outras situações sociais e com outra dimensões da realidade social, inclusive macro-sociológicas. Tal como teoricamente antecipado, a natureza do espaço é um determinante importante da dinâmica interna à situação de procura e, nela, à atuação de cada tipo de ator. Assim, seria impossível descrever a conduta de cada ator desprezando a relação que ele tem com o espaço, através de suas formas de apropriação; da mesma forma que não teria sentido descrever o espaço exclusivamente através de seus dispositivos físicos, ignorando os usos e apropriações sociais que dele se faz. O processo de procura analisado é espacialmente organizado; este foi o ponto de partida que deu sentido ao presente capitulo.

Para começar, podemos reiterar que as estratégias de atuação das agências de emprego são tão articuladas com a dinâmica da situação e do espaço que a grande maioria delas é, em alguns casos mais e em outros menos, dependentes do poder de atração de demandantes daquele território. Dessa forma o próprio enraizamento dessas firmas naquela dinâmica espacial passa a ser uma boa categoria para subdividi-las e para analisá-las vis-à-vis sua relação com o espaço, mas também com os seus próprios funcionários e com os demandantes de trabalho. A relação que os plaqueiros estabelecem com o espaço também os diferencia entre si; uns circulam pelas ruas, outros circulam apenas pela Rua Barão de Itapetininga, outros ficam no mesmo lugar o dia todo. E mesmo essa 
ocupação do espaço não é trivial e desorganizada; alguns plaqueiros ocupam, com legitimidade e respeito dos demais, o mesmo espaço da rua há anos, outros têm que concorrer por espaços.

Ainda, os dispositivos físicos da situação criam uma estratégia de procura, por parte dos demandantes, que se dá em duas fases extremamente relacionadas com o espaço em que se estabelecem: a primeira, na rua, através dos plaqueiros e dos cartazes; a outra, nos edifícios e galerias, através de uma exaustiva peregrinação entre escadas e elevadores para chegar às agências. Além disso, a relação que os demandantes de trabalho podem estabelecer com aquele espaço é tão importante que ela chega a extrapolar os limites daquela situação de procura, permitindo a vivencia de uma experiência urbana e social que enriquece os sentidos da experiência de procura de trabalho, como será desenvolvido no próximo capítulo. Aqui basta notar o espaço como uma categoria que também permite articular diferentes experiências sociais.

No que diz respeito à articulação dos usos do espaço, é importante repetir que esses usos são múltiplos e se sobrepõem. Os usos do espaço que aqui constituem o "território da procura de trabalho" também são múltiplos, se sobrepõem e se fortalecem, à medida que fortalecem também as práticas que tornam aquele espaço um reconhecido território de procura de trabalho. Pretende-se chamar atenção para articulação de usos do espaço, mas também para a conexão daquele território com fenômenos sociais exteriores a ele.

Interessante notar que a articulação de práticas e usos se dá também pela articulação de dimensões espaciais que nem mesmo pertencem à mesma natureza. Para começar, me refiro aqui à articulação do espaço físico e do espaço virtual. Hoje em dia a procura de trabalho perpassa essas duas dimensões (presencial e virtual), com destaque para o crescimento da importância da segunda dimensão. O que importa aqui é a forma como uma dimensão perpassa a outra, também gerando uma sobreposição de espaços que torna o território estudado ainda mais interessante. Apesar do fluxo intenso, relatos apontam para uma queda do movimento de demandantes na região. Isso também pôde ser notado ao longo das observações realizadas nos últimos anos ${ }^{58}$. A causa dessa queda do número de demandantes, como insistentemente apontado, é a internet. Á medida que a internet vem se tornando uma ferramenta mais utilizada e democrática, a ela também acorrem às agências de emprego. Antes, apenas as melhores vagas e aquelas que seriam preenchidas por

\footnotetext{
58 Do início das observações, em 2005, até o começo da crise econômica mundial, no segundo semestre de 2008 foi possível notar uma queda do movimento, que, porém, cresceu novamente no período de crise, devido ao aumento do desemprego. Porém, mesmo nesse momento de retomada do movimento, ele não se iguala ao que era observado no começo das observações. A fila no Edifício Rio Branco, por exemplo, está menor hoje do que na fase inicial da pesquisa de campo. Muitas agências de emprego fecharam e muitas operam com as portas fechadas.
} 
candidatos mais qualificados ficavam disponíveis na internet. As vagas operacionais e desqualificadas eram predominantemente anunciadas na própria rua ou no jornal. Porém, isso está mudando e as agências estão investindo cada vez mais na captação de candidatos através da internet, com a criação de sites e bancos digitais de currículos próprios, além da sofisticação das ferramentas de seleção e busca virtual de candidatos ${ }^{59}$.

Mas essa mesma tendência criou a necessidade de um outro serviço ofertado naquele comércio, pois o acesso e os conhecimentos da ferramenta de internet não são, de fato, tão democráticos assim. Muitos dos que procuram trabalho na Barão não têm acesso à internet e nem sabem como utilizá-la. Dessa forma, os negócios que antes ofereciam a confecção de currículos agora fazem, como um de seus serviços, a distribuição desse currículo pela internet, envolvendo-se e responsabilizando-se mais ainda pelo processo de procura. Esses negócios ofertam também o acesso à internet, funcionando assim como lan houses. O curioso é que, hoje, algumas pessoas se deslocam até àquele espaço não apenas para procurar as agências de emprego, mas também para procurar esses estabelecimentos que possibilitam e se responsabilizam, de alguma maneira, pela realização do processo de procura virtual. No que diz respeito ao crescimento da importância da internet na procura, cabe ressaltar que há, portanto, uma sobreposição dos espaços físico e virtual e não uma justaposição dos dois, onde um exclui o outro, mas pelo contrário, onde um complementa o outro. As experiências da procura virtual e presencial, que são distintas, podem se realizar na mesma situação de procura.

Ainda que a presença física das antigas agências naquele espaço pareça estar perdendo importância, o que é questionável, outras atividades e serviços, como os correlatos à procura, reiteram a natureza de "território de procura de trabalho" que qualifica aquela região. Da mesma forma, empresas que nem estão localizadas ali mandam plaqueiros e selecionadores próprios para aquele espaço, em busca de candidatos, prescindindo das agências intermediadoras, e fazendo uso do poder de atração de demandantes que tem o território, o que sugere que esse, com seus usos e apropriações relacionados à procura, é mais forte que o mercado de intermediação em si. À medida que surgem novos atores, instituições, serviços e possibilidades, a situação de procura se torna mais complexa, mais rica e singular enquanto uma dinâmica própria, fazendo que o poder de atração de demandantes daquele território também aumente.

Pretende-se chamar atenção também para a relação do referido espaço com outros espaços e atores da cidade, captando a forma como ele, apesar de ser um espaço sui generis, também está

$59 \quad$ Hirano (2007) já pôde detectar essa tendência durante seu trabalho de campo no ano de 2006. 
inserido na dinâmica urbana mais ampla e na dinâmica de poder relacionada, em tese, com atores exteriores àquele território de procura. $\mathrm{O}$ trabalho de campo pôde flagrar um momento de tensão entre aquele espaço e o poder público, através de diretrizes e iniciativas urbanísticas governamentais mais amplas, que tiveram e ainda têm repercussão em toda a cidade. Aqui a referência é o "Projeto Cidade Limpa”, implantado em 2006 pela gestão Kassab da Prefeitura de São Paulo. Como o próprio nome diz, o objetivo do projeto é mudar a cara da cidade, combatendo, principalmente, a poluição visual. Os alvos foram, no princípio, os anúncios, propagandas e fachadas de estabelecimentos comerciais, que precisaram ser removidos ou regularizados. Porém, na esteira desse movimento, supostamente voltado a "embelezar" a cidade, a guerra aos mendigos e aos camelôs foi declarada, principalmente no Centro. Essa tendência foi posta em prática por uma série de ações da Subprefeitura da Sé, com o apoio da ONG "Viva o Centro", que defende a revitalização da região central da cidade. Os "cedezeiros", ambulantes que vendem CDs e DVDs piratas, tornaram-se "o grande vilão do Centro" durante o ano de 2008 e têm sido fortemente combatidos por meio de fiscalização intensa. Tendo sido razoavelmente contornado o problema dos camelôs ${ }^{60}$, a atenção recaiu sobre outras fontes de "poluição" do espaço: os plaqueiros e os anúncios de emprego que caracterizam aquele território. Passou-se a condenar e combater uma série de práticas já antigas por parte desses personagens, mas que nunca ou só raramente haviam sido questionadas pelo poder público, como o uso de banquinhos, cadeiras e caixotes, tanto para sentar, quanto para veicular anúncios de emprego. Aos plaqueiros cabe somente ficar em pé e as informações sobre vagas de trabalho ou outros serviços só podem ser veiculadas em seus corpos. Ou seja, colar anúncios nas paredes, nos muros, no chão ou nos poste da rua, práticas ilegais, mas antes toleradas, passaram a ser combatidas. Recolher currículos das mãos dos demandantes de trabalho na rua, prática cada vez mais comum, é ilegal, à medida que configura comércio em espaço público, e que se almeja combater. Essas práticas têm sido reprimidas pelos fiscais da Sub-prefeitura da $\mathrm{Sé}^{61}$ e desde então o clima tem sido de tensão. A preocupação não é tanto com os bancos ou caixotes, que podem ser facilmente substituídos, mas com a proibição da coleta de currículos, como desenvolvido no item 6 ,

\footnotetext{
60 A Rua Barão de Itapetininga, antes ocupada por esses ambulantes, vê-se hoje ocupada por policiais e viaturas das Guarda Civil e Metropolitana e da Polícia Militar; os “cedezeiros” só ocasionalmente aparecem por lá. Apenas os ambulantes licenciados permanecem com seus negócios e, mesmo assim, são recorrentemente fiscalizados e, não raro, têm suas licenças e mercadorias apreendidas, se constatada alguma irregularidade.

61 Tive a oportunidade de observar o processo de treinamento de novos fiscais da Subprefeitura em julho de 2008. O "braço direito" do Subprefeito na época conduzia uma equipe de cerca de quinze homens pela rua Barão de Itapetininga e suas adjacências mostrando-lhes, in loco, as irregularidades que eles, na qualidade de fiscais, deveriam combater. Este senhor, que então ocupava o cargo de Coordenador de Assistência Social e Desenvolvimento da Subprefeitura da Sé, ele próprio um velho conhecido do pessoal da rua, apontava os bancos usados pelos plaqueiros e condenava a coleta de currículos por parte desses trabalhadores, prática cada vez mais comum.
} 
que pode ter repercussão na forma de atuação das agências de emprego ali estabelecidas e na apropriação do espaço, subvertendo a ordem que foi estabelecida pelos personagens locais, em que se sustentava aquela dinâmica de procura de trabalho, tal como convencionalmente constituída. Essa mudança poderia ter impacto na dinâmica de funcionamento das agencias e de interações que se dão rua. Porém, devido à processos informais de negociação com os agentes da Guarda Metropolitana, os plaqueiros continuam a realizar sua atividades com base nas mesmas práticas de antes. Ocorre uma mudança na expectativa que um ator (poder público) tem sobre atuação de outros atores (plaqueiros), o que, nesse caso, implicaria na imposição de uma mudança da dinâmica da situação e essa mudança imposta da ordem gera conflitos. Há, portanto, um processo de quebra da ordem típica daquele espaço que se dá pela tentativa forçada de mudança das regras da situação, a qual passa ser temporariamente re-estabelecida através de processos negociativos. Ressaltam-se as relações de concorrência, conflito e negociação que os atores estabelecem pelo uso do espaço e para tentar controlar a dinâmica da situação.

Ainda no que diz à relação daquele território com a dinâmica mais ampla da cidade, é fundamental repetir que o poder de atração de demandantes de trabalho está diretamente relacionado à articulação da região da Barão com a malha urbana e com o sistema de transporte público da cidade, que permitem um acesso facilitador tanto por meio de carro, quanto através de transporte público. A localização desse território no Centro da cidade aumenta substancialmente a sua acessibilidade, se comparado a outros clusters de intermediação de mão-de-obra. Sem falar que a localização no Centro permite a articulação da atividade de procura de trabalho com outras atividades por parte dos demandantes como compras, lazer ou resolução de pendências da vida cotidiana, tais como a consulta a médicos, advogados, pedidos de empréstimo e etc. Esse fator também aumenta as vantagens desse espaço de procura de trabalho frente a outros e faz com que a procura de trabalho naquele território ganhe outras dimensões e se caracterize também como uma experiência de consumo e de vivência da cidade. Essa discussão será aprofundada no capítulo seguinte.

Por último, cabe destacar que há um outro fator de natureza macro que afeta diretamente a dinâmica daquele espaço: a economia encarnada pelos movimentos do mercado de trabalho. Momentos de crise econômica e crescimento do desemprego aumentam o movimento de demandantes à procura de trabalho; a rua fica mais movimentada, as filas ficam mais longas, as lan houses e os estabelecimentos que fazem e copiam currículos ficam mais cheios, as agências recebem mais currículos. Nesses momentos aquele espaço é procurado por um volume maior de 
demandantes, porém, a chance de obtenção de trabalho é menor, pois aumenta a demanda de trabalho, mas diminui a oferta. Aumento da oferta de trabalho também incide, obviamente, sobre a dinâmica do lugar. O período de um ano é marcado por períodos de aumento e queda do movimento no território de procura de trabalho e essas temporadas são marcadas fundamentalmente por ciclos de aumento de oferta de postos. O melhor exemplo é o crescimento da oferta de trabalhos temporários em comércio e indústria no final do ano, estimulado pelo aumento da produção e das vendas típico desse período, que eleva incrivelmente o movimento da região nos meses de setembro e outubro, à medida que decai substancialmente o movimento nos meses de novembro e dezembro, quando a oferta de trabalhos temporários também diminui. Essa mesma tendência também se expressas nos períodos que antecedem a Páscoa ou o Dia das Mães, por exemplo, embora em menor proporção que no Natal. Há períodos de baixa, no entanto, em que tanto a oferta quanto a demanda de trabalho diminuem. O período que gira em torno do mês de maio, mês do dissídio, em que as demissões são proibidas, é o período de menor movimento, conforme observações e relatos. Esses movimentos de alta e baixa, influenciados pela economia, alteram a intensidade do uso daquele espaço pelos demandantes, a lucratividade das instituições comerciais e a relação entre os atores, pois, a intensidade e duração das interações dos plaqueiros e das recepcionistas com os demandantes, por exemplo, também são ditadas pela quantidade de pessoas que eles têm que atender e dar atenção. Quando o movimento é menor, a interação pode ser mais intensa e longa e o contrário é verdadeiro para os períodos em que o movimento é maior.

Um determinado espaço de procura de trabalho configura uma situação de procura específica e diferenciada, a qual é conformada pela relação entre os diversos atores que ali atuam, mas também pela relação com atores exteriores àquele espaço e pela relação com outros espaços. Ou seja, a intenção é demonstrar que o espaço também é uma categoria fundamental para pensar tal situação social, pois a partir dele podemos apreender a especificidade da situação e das relações que ela cria, assim como é possível apreender também a membrana de contato dessa situação com outros processos sociais mais amplos. A partir do espaço podemos captar elementos micro-sociológicos que delineiam a situação de procura, como pontes com fenômenos macro-sociológicos que acabam por atuar sobre as interações e as condutas lá desenvolvidas.

Tratando mais explicitamente das interações, é possível afirmar que os atores têm nessa situação, como nas demais situações sociais, possibilidades de manejar as informações emitidas (verbais ou gestuais) e sua própria atuação, manipulando, de alguma forma, a interação com os outros atores na situação social e agindo sobre a mesma sem, contudo, desprezar as regras de 
ordenamento e os códigos implícitos, os quais formam a base do léxico social que engendra aquela dinâmica. Ao longo do capítulo foram citadas diversas possibilidade de manipulação de informações e negociações por parte dos atores da situação.

Porém, para além dessas técnicas interativas, notamos também que é necessário que haja conhecimento das regras e códigos da situação de procura e das expectativas que cada ator tem em relação a outro. Essa é a condição para que as interações sejam adequadamente desempenhadas e a “ordem interativa” típica daquela situação seja estabelecida e mantida. Quando há mudança das expectativas, como no caso da mudança das regras de atuação dos plaqueiros, pode haver conflito. Quando há desconhecimento das expectativas do outro, pode haver constrangimento e frustração, como pode acontecer na interação entre selecionador e demandante em um processo seletivo, quando esse último não sabe o que esperam de um bom demandante de trabalho. Ou seja, mudanças nas regras ou incompreensões das mesmas pode gerar, a princípio, ruídos na orquestração da dinâmica das interações. Mas, há sempre a possibilidade de negociações e re-adaptações para o restabelecimento da ordem das interações.

No que diz respeito às interações entre atores do mesmo tipo, ou seja, entre aqueles que desempenham o mesmo papel, é possível dizer que elas podem estar, em alguns momentos da vivência da situação de procura, baseadas na concorrência. Isso é especialmente verdadeiro para os demandantes de trabalho que, em processos seletivos, disputam os mesmos postos de trabalho, mas também é verdadeiro para as agências de emprego que, enquanto parte do mesmo mercado, disputam não só clientes, mas também candidatos. Os estabelecimentos que ofertam serviços conexos à procura de trabalho têm sua concorrência por clientes explícita nas diversas promoções anunciadas na rua. E, até mesmo os plaqueiros, concorrem entre si por espaços estabelecidos da rua e por visibilidade.

Como fortemente articulados dentro da situação de procura, uma prática típica de um ator ou instituição tem reflexo na dinâmica geral de práticas e interações com os demais. As estratégias de captação de candidatos por parte das agências através de plaqueiros e anúncios na rua, por exemplo, influenciam toda a dinâmica de procura de trabalho daquele território e constroem interações peculiares daquela situação. O delineamento de uma prática, como a citada, interfere na situação, inserindo novos atores e criando novas interações. Reforçando esse argumento, podemos dar ainda outro exemplo. A relação entre demandantes e agência é mediada ali pelo uso de um instrumento, o currículo. Essa prática, que não é natural, mas socialmente construída, acabou gerando um conjunto de outras práticas típicas, engendradas num mercado paralelo ao mercado de intermediação, através 
da elaboração e duplicação desses currículos. À medida que as agências passaram a investir na captação virtual de candidatos, outros estabelecimentos surgiram, facilitando ou se responsabilizando pela procura virtual. Ou seja, as instituições e os atores estão articulados de forma que uma prática ou mudança das agências pode influenciar a dinâmica geral da situação.

Já as múltiplas formas de atuação que cada um dos plaqueiros pode exercer na rua também influenciam a construção da situação, pois cada tipo de atuação/ performance de plaqueiro divulgação de vagas, recebimento de currículos e captação de candidatos - determina um tipo de interação com os demandantes que, por tabela, determina o tipo de interação entre o demandante e a agência de emprego que o plaqueiro representa na rua. Isso porque há um "consenso operacional", no qual cada ator compreende as ações e a conduta do outro e interage com ele a partir dessa compreensão; a ação de um é também determinada pela ação daqueles com quem ele interage e essa orquestração de ações e condutas que se constrói na base do sentido compartilhado é o que Goffman chama de "ordem interacional".

Os demandantes de trabalho, por sua vez, investidos de sua conduta social - o tipo de comportamento minimamente padronizado que se espera de uma pessoa em busca de trabalho também determinam a sua própria interação com os atores que configuram aquela situação. Do bom ou mau desempenho dessa conduta depende a forma como ele será visto na situação pelos outros atores e é a partir dessa imagem transmitida através de práticas, palavras e gestos que a interação do demandante com os outros atores se construirá. Essa conduta também se constrói com base nas expectativas daqueles com quem se interagirá e, para isso, é preciso compreendê-las tanto quanto dominar os códigos de atuação da conduta esperada para poder colocá-la em prática, encená-la. Aqui cabe ressaltar a importância da linguagem verbal, visual e gestual na construção da situação social, tal como defende Strauss, e dos processos comunicacionais socialmente partilhados na formação das identidades coletivas e das condutas sociais. Essas condutas são situadas, e, portanto, articuladas à situação social em que transcorrem, porém, sua construção não se limita àquele momento.

As condutas são, como tentamos mostrar, e como exploraremos melhor no capítulo seguinte, formadas por processos múltiplos e complexos, que se iniciam muito antes do momento de atuação na situação de procura de trabalho. A conduta social do demandante de trabalho é formada também por processos de aprendizagem que se dão na esfera familiar, na convivência com amigos, na vivência no mundo do trabalho e através dos mais diversos meios de comunicação. Dessa forma, a conduta que é momentaneamente encenada na procura de trabalho pelo demandante está 
extremamente articulada ao espaço e aos atores que formam aquela situação social, mas também está articulada à representações sociais engendradas em outras dimensões da vida social como a família, a escola , o trabalho, a economia e os meios de comunicação.

São essas outras articulações que exploraremos no capítulo seguinte no qual o foco será a experiência da procura de trabalho, sempre mediada por significados sociais, por outras vivências dos demandantes assim como por suas características sociais (condição sócio-econômica, idade, posição na família e trajetória ocupacional). Tentaremos apresentar no capítulo seguinte algumas pontes e mediações entre aquela situação social, tomada como unidade de análise, e outras dimensões da vida social do demandante, para seguir explorando as membranas de contato daquela realidade sociológica com outras, de natureza micro ou macro, e entender um pouco mais a experiência social da procura de trabalho.

No presente capítulo, no entanto, o que se buscou foi enfatizar justamente as membranas que criam uma dinâmica interna e tornam aquela situação social uma realidade sui generis, uma unidade analítica em si, que se diferencia de outras, já que dotada de dinâmica, atuações, interações, práticas e códigos muito próprios. 


\section{CAPÍTULO 4}

\section{Os demandantes e a experiência da procura de trabalho}

Esse capítulo é dedicado a tratar mais de perto elementos da experiência social da procura de trabalho, tal como vivida pelos demandantes, e a partir de seus próprios discursos. Nele, o demandante entra e cena como personagem privilegiado da análise, já que é ele aquele que, de fato, procura um emprego e vivencia a experiência da procura de trabalho. Experiência que não é apenas individual, mas que é também social.

A experiência social da procura seria o resultado da vivência de variadas situações sociais por parte desses demandantes. As situações de procura, tal como a que foi descrita e analisada no capítulo anterior, são constituintes dessa experiência social, como adiantamos. Porém, a situação de procura descrita, com todos seus elementos, regras e práticas, seria apenas um exemplo, entre outros possíveis, de situação de procura e uma forma, entre outras existentes, de viver a procura de trabalho. Ao descrevê-la, ao modo do capítulo anterior, tencionava-se captar uma vivência situada de procura de trabalho para entender melhor os processos que se desenrolam, as práticas cotidianas por meio das quais se constrói essa experiência. Estudar a procura de trabalho a partir de uma situação mostrou-se pertinente também porque sabemos que as condutas são situadas e a conduta do demandante de trabalho, como as demais, depende da situação na qual é colocada em prática, isto é, do espaço na qual ela se desenvolve, das relações que esse demandante estabelece com as instituições ali atuantes e das interações que estabelece com os atores que partilham a situação. Isso porque tal conduta pode ser negociada, manipulada e readaptada no curso das interações que se estabelecem na situação de procura. Porém, como já adiantamos no capítulo anterior, mesmo que dotada de uma lógica social interna, a situação de procura de trabalho, como unidade analítica, está articulada a outras situações sociais e outros fenômenos sociais.

Do mesmo modo, a experiência da procura de trabalho, da qual a vivência da situação social de procura é constitutiva, está também articulada a outras dimensões sociais da vida dos demandantes. Em primeiro lugar, está articulada às características sociais dos demandantes tais como: idade, sexo, cor, profissão, escolaridade, condição sócio-econômica, posição na família, entre outras. Diferentes configurações dessas características produzem contextos sociais distintos e formas diferentes de viver a situação de procura. Em segundo lugar, a vivência daquela situação baseada também em códigos, ensinamentos e aprendizados sociais que são apreendidos em outras esferas da 
vida social do demandante, ou seja, a partir de outras vivências. E, além disso, a própria atividade de trabalho pode propiciar aos demandantes vivências sociais de outras naturezas.

As características sociais e as diferentes vivências sociais de cada demandante são elementos que, apesar de influenciarem na vivência da situação de procura, estão para além dela e configuram diferentes experiências de procura. Tentaremos explicitar esses dois elementos para compreender um pouco mais sobre essas mesmas experiências. A terceira dimensão da experiência da procura que tentaremos explorar aqui é o conjunto de significados sociais associados a essa atividade, ou seja, quais os sentidos que a procura de trabalho pode assumir na vida dos demandantes. Esse capítulo abordará esses três elementos, que foram aqueles que as entrevistas permitiram captar. Sabe-se, no entanto, que a construção dessa experiência da procura de trabalho é mais complexa, composta por outros elementos além dos que são tratados aqui.

As interpretações subseqüentes estão baseadas nos relatos colhidos através das entrevistas com 24 demandantes de trabalho, colhidas na situação de procura de trabalho investigada. Aqui é importante ressaltar que essa coleta de discursos não foi pautada pela busca de representatividade inerente aos estudos quantitativos; pretendeu alcançar, antes, a riqueza dos relatos dos demandantes de trabalho que foram escolhidos de modo a contemplar-se a diversidade social que se apresenta naquele universo.

Ressaltamos também que essas interpretações a respeito da experiência da procura de trabalho são preliminares e tentativas, já que foram captadas a partir de entrevistas que não tinham apenas esse alvo. Isso porque, se os roteiros de entrevista tinham como alvo principal a situação de procura de trabalho no território da Rua Barão de Itapetininga, eles também buscavam estimular discursos que permitissem fazer apontamentos sobre outras dimensões da experiência da procura. O tipo de roteiro aplicado e o ambiente em que as entrevistas tinham que transcorrer não estimulavam elaborações subjetivas muito densas e longas; apesar disso, pôde-se captar discursos muito ricos e pistas muito interessantes, que se buscará aproveitar aqui. Acredita-se, porém, que para o tratamento mais elaborado dessa questão caberia um estudo que estimulasse mais as narrativas sobre a experiência social de procura e um investimento mais profundo de captação de discursos e subjetividades. Aqui pretendemos avançar, dentro do possível, nas questões referentes à experiência da procura de trabalho, lidando apenas com algumas de suas dimensões constitutivas, mas, principalmente, deixar pistas para progressos futuros.

Para empreender a análise da experiência da procura de trabalho, esse capítulo trabalhará com os três de seus elementos constituintes: i) contexto social e características sociais dos demandantes, 
ii) articulação da vivência da procura com outras vivências sociais e iii) significados sociais da atividade de procura de trabalho. Esse capítulo, portanto, é divido em três partes distintas, sendo que cada uma delas tenta problematizar um desses elementos da experiência social da procura. Ao longo dessas três partes tentar-se-á ainda explicitar elementos subjetivos, como sensações e sentimentos, que são muito típicos dessa experiência social e que foram evidenciados pelos informantes.

\section{Características sociais, expectativas e dificuldades: tipos de demandantes e de experiências de procura}

Parte-se do pressuposto, o qual foi confirmado pelas análises dos discursos, que diferentes configurações de características sociais dos demandantes engendram experiências sociais de procura de trabalho também diversas. Isso porque a essas características estão associadas dificuldades e expectativas, as quais interferem nas ações e decisões tomadas durante a procura de trabalho e conferem a essa experiência social diferentes significados sociais. Tomamos o conjunto de características sociais de cada demandante, que também pode ser entendido como contexto social, como um dos elementos constituintes da experiência da procura. E à medida que são constituintes, também delineiam diferentes tipos de experiência. Essas características definem os constrangimentos que o demandante vai encarar na sua busca, assim como os significados que esse processo vai adquirir, ou seja, definem os contornos da vivência dessa experiência social.

Para iniciar o trabalho de interpretação foi construída uma tipologia dos demandantes de trabalho entrevistados, tendo como base suas características sociais (idade, sexo, escolaridade e origem social), mas também suas expectativas, objetivos e dificuldades na procura associadas a essas características e narradas nas entrevistas, as quais são constituintes da experiência social da procura de trabalho.

Os 24 demandantes de trabalho, que coincidentemente, também eram todos desempregados, foram classificados em quatro tipos, tendo em conta as características que mais os aproximavam entre si e os diferenciavam frente aos outros. Cada um deles representa não só um tipo de demandante de trabalho, mas também um tipo de experiência social de procura de trabalho, marcada por representações sociais (expectativas, objetivos, dificuldades, constrangimentos sociais e sentimentos) que influenciam ações e decisões tomadas durante o processo de procura e a forma de ver e viver aquela situação específica. Os tipos foram construídos a partir de um conjunto de características: idade, posição na família, condição social, escolaridade, trajetória de trabalho 
anterior e tipo de trabalho procurado. È importante ressaltar que parcela considerável dos demandantes que acorrem ao cluster de intermediação do Centro é formada por demandantes jovens e/ou provenientes de origens sociais desfavorecidas e que essas características se refletem no perfil do grupo de demandantes entrevistados. Como se poderá notar, as expectativas, dificuldades e as subjetividades referentes ao processo de busca também são centrais na configuração de cada um dos tipos, que são: a) Busca do primeiro emprego, b) Jovens adultos em busca de um bom emprego, c) Jovens adultos em busca de um emprego com urgência e d) Adultos em busca de um novo emprego.

Esses quatro tipos inspiram-se nos três tipos principais encontrados na análise quantitativa dos dados do survey por amostra representativa. Com efeito, Guimarães e Melo (2008), utilizando a técnica do "grade of membership" (GOM) para uma amostra de cerca de 1500 casos de demandantes em busca de trabalho em agencias em São Paulo, encontraram três tipos principais ("tipos puros", conforme a terminologia do GoM) que recobriam a maioria dos casos e que mostravam um perfil bastante homogêneos de características (para o que os autores lançaram mão de cerca de 70 diferentes variáveis). Guimarães e Melo denominaram estes tipos como sendo: “os muito jovens em busca de um primeiro emprego", "os jovens adultos em busca de um melhor emprego" e "os adultos em busca de um novo emprego". Observamos que a grande maioria dos 24 casos entrevistados no Centro em grande medida também refletia este perfil, conquanto um quarto grupo típico devesse ser agregado, o dos "jovens adultos em busca de um emprego com urgência".

Partindo do discurso dos demandantes foi possível perceber que a idade e as representações sociais que giram em torno de cada faixa etária e de cada ciclo de vida interferem muito na forma de viver o desemprego e de encarar a procura de trabalho. O mesmo se passa com a posição na família e no provimento da renda familiar. Destaca-se igualmente a necessidade de tomar a experiência anterior de trabalho dos indivíduos para entender a experiência do desemprego (já que todos eram desempregados) e de procura de trabalho; também o tempo de procura também é determinante da forma de encarar essa experiência. A condição sócio-econômica da família, assim como a presença ou não de redes sociais de apoio material e psicológico contribuem, como veremos, sobremaneira para o delineamento da mesma. E o maior ou menor domínio dos códigos e práticas necessários ao bom desempenho da conduta de demandante de trabalho também influencia nessa construção subjetiva. Vimos que todos esses fatores determinavam os constrangimentos que os demandantes tinham que enfrentar na experiência de procura, mas podiam determinar também a forma como os próprios demandantes interpretam sua experiência e nela constroem suas ações e tomam suas decisões. 


\subsection{Em busca do primeiro emprego.}

Quatro são os entrevistados que se encaixam nessa classificação: Juliana (17 anos), Elisa (18 anos), Darcio (16 anos) e Mara (37 anos). Com exceção de Mara, de 37 anos, os três demais são muito jovens; estão no grupo dos mais jovens entrevistados. Os quatro não possuem experiência de trabalho regular anterior, embora já tenham realizado atividades ocupacionais de forma irregular ou não remunerada. Não possuem a "experiência comprovada" e é isso o que eles buscam, um trabalho que eles possam comprovar na carteira ou colocar no currículo. É a primeira vez que eles procuram trabalho ativamente.

Mara (37 anos) é dona-de-casa e mãe de três filhos, tem fundamental incompleto e nunca teve um emprego formal e regular; o marido sustentava a casa e ela, ocasionalmente, lavava e passava roupa para fora, como complemento à renda familiar. Devido às recentes dificuldades financeiras que a família vem sofrendo desde que seu marido ficou doente, ela resolveu procurar trabalho regular estável e se encontrava na Rua Barão de Itapetininga com seu filho e sobrinho, ambos de 19 anos, que também procuravam trabalho e foram entrevistados. Devido à sua pouca escolaridade e à falta de experiência, ela buscava algum trabalho na área de limpeza. Era a primeira vez que ela ia ao cluster de intermediação de mão-de-obra do Centro; foi levada pelo filho e sobrinho, que foram os responsáveis pela elaboração do currículo dela. Ela nunca havia participado de um processo eletivo, estava muito insegura, mas também otimista.

Juliana, 17 anos, tem curso médio incompleto e nunca trabalhou; buscava trabalho de vendedora, operadora de telemarketing ou recepcionista. Ela sabia que, sem experiência, teria que aceitar o que aparecesse, mas, a princípio, não aceitaria trabalho manual ou "trabalho pesado", como ela disse. Sua preocupação era arrumar um trabalho que lhe permitisse ganhar experiência, pois, em breve, precisaria de um "bom" emprego que a possibilitasse pagar a mensalidade da faculdade que ela faria no futuro, quando terminasse o curso médio. Juliana tinha bastante apoio da família em seu processo de busca, tanto emocional quanto no custeio dos gastos envolvidos na procura de trabalho.

Darcio, 16 anos, já havia trabalhado em loja, mas apenas como temporário e sem registro. Queria um trabalho na área de vendas ou telemarketing, que lhe permitisse ajudar na renda familiar, mas, principalmente, adquirir experiência. Darcio assumiu que não dominava muito bem os códigos da procura e que tinha medo dos processos seletivos, pois era tímido. Mas estava empenhado em 
superar essa dificuldade para conseguir um trabalho. Ele disse que buscava informações e dicas sobre procura de trabalho na internet e nas conversas com amigos e vizinhos.

Elisa, de 18 anos, já havia trabalhado como ajudante na papelaria de sua madrinha e acabara de ingressar no nível superior, fazendo curso de Turismo em uma universidade particular. Ela buscava um emprego que lhe possibilitasse pagar a faculdade e tinha extrema urgência em encontrá-lo, pois sua madrinha se comprometeu a ajudá-la apenas nos primeiros meses, enquanto ela não arrumasse trabalho. Elisa estava na companhia de duas vizinhas que também procuravam trabalho e já tinha ido às agências do Centro quatro meses antes da entrevista. Na ocasião, ela foi chamada para dois processos seletivos, um para promotora de vendas e outro para recepcionista, mas não passou em nenhum dos dois. Ela acreditava que isso teria acontecido porque ela nunca tinha participado de processos seletivos e estava muito insegura; no entanto, desta vez achava que dessa teria mais sucesso, pois já estava procurando há alguns meses e dominava melhor os códigos.

\section{Quadro 4.1.Características dos demandantes do grupo "Em Busca do Primeiro Emprego"}

\begin{tabular}{|l|l|l|l|l|l|}
\hline Nome & Moradia & Idade & Escolaridade & Profissão & O que procura \\
\hline Juliana & $\begin{array}{l}\text { Jardim } \\
\text { Marisa }\end{array}$ & 17 & $\begin{array}{l}\text { E Médio } \\
\text { Incompleto } \\
\text { Está estudando }\end{array}$ & $\begin{array}{l}\text { Busca do } \\
\text { primeiro } \\
\text { emprego }\end{array}$ & $\begin{array}{l}\text { Telemarketing } \\
\text { Recepcionista } \\
\text { Vendedora }\end{array}$ \\
\hline Mara & Vila Matilde & 37 & $\begin{array}{l}\text { E fundamental } \\
\text { completo }\end{array}$ & $\begin{array}{l}\text { Dona-de-casa } \\
\text { Busca do } \\
\text { primeiro } \\
\text { emprego }\end{array}$ & $\begin{array}{l}\text { Limpeza } \\
\text { Manutenção } \\
\text { Vendas }\end{array}$ \\
\hline Darcio & $\begin{array}{l}\text { Vila } \\
\text { Clementino } \\
\text { (V. Mariana) }\end{array}$ & 16 & $\begin{array}{l}\text { E Médio incompleto } \\
\text { Está estudando. }\end{array}$ & $\begin{array}{l}\text { Busca do } \\
\text { primeiro } \\
\text { emprego }\end{array}$ & $\begin{array}{l}\text { Vendas } \\
\text { Telemarketing }\end{array}$ \\
\hline Elisa & Mooca & 18 & $\begin{array}{l}\text { E Superior incompleto } \\
\text { (turismo) }\end{array}$ & $\begin{array}{l}\text { Busca do } \\
\text { primeiro } \\
\text { emprego }\end{array}$ & $\begin{array}{l}\text { Vendas } \\
\text { Recepção }\end{array}$ \\
\hline
\end{tabular}

Fonte, Levantamento de campo, 2009.

Na busca de Darcio e Juliana o que se fazia mais importante era a experiência comprovada de trabalho, enquanto que para Mara e Elisa a necessidade de uma renda era mais urgente e o fator determinante da procura. No discurso deles havia também um tom muito próprio: para eles a procura de trabalho constituía uma experiência nova, sobre a qual (e com a qual) estavam aprendendo ou ainda tinham muito a aprender. Os demandantes desse grupo demonstraram dificuldades no domínio dos seus códigos e práticas. O difícil acesso às informações sobre oportunidades de trabalho também constitui uma marca desse grupo. Juliana, Mara e Darcio 
disseram que não sabiam muito bem onde e nem como procurar. A família se mostrou importante como meio de sociabilização de informações e dos códigos da procura, mas o próprio processo de procura também se mostrou importante nessa aprendizagem e incorporação de códigos. Porém, apesar das diversas dificuldades, dúvidas e incertezas, o otimismo é outra característica do discurso desse grupo de entrevistados. Eles pareciam acreditar que, caso se empenhassem na procura, iriam achar um trabalho.

Aqui nesse grupo, a pouca seletividade e disponibilidade para aceitar um trabalho que não fosse "o emprego dos sonhos" não vem acompanhada de pessimismo ou derrotismo, pois, está associada a uma necessidade circunstancial e momentânea, alheia a seus atributos pessoais, mas decorrente de vicissitudes do curso da vida ou do contexto. Eles sabiam que, pela falta de experiência, não acessariam trabalhos muito bons (mais qualificados e bem remunerados) e aceitariam o que aparecesse, com a expectativa de, no futuro, pudessem vir a alcançar um posto melhor, aquele que exige a experiência que eles ainda não têm. A consciência da dificuldade em conseguir trabalho pela falta de experiência profissional diminuía as suas expectativas, levando-os a uma busca menos direcionada e exigente. A procura de trabalho parecia menos um fardo e mais um desafio natural do momento de vida que eles atravessavam.

\subsection{Jovens adultos em busca de um bom emprego}

São sete os entrevistados que podem se encaixar nessa categoria: Ana Maria, Juliano, Wellington, Rogério, Fabiana, Sandro e Adriano. Todos são jovens, com idades que variam de 17 a 20 anos, mas já possuem alguma experiência de trabalho e procuram ou uma vaga que se encaixe, minimamente, na sua área de atuação precedente ou então buscam um posto melhor do que o que tinham antes, por terem feito algum investimento de qualificação que lhes teria dado o crédito para almejar essa melhora.

Ana Maria e Fabiana possuem perfis parecidos. As duas possuem nível médio incompleto e continuavam estudando; buscavam, portanto, um trabalho que pudesse ser articulado ao estudo, sem prejuízo desse último. Ana Maria (19 anos) teve várias ocupações como vendedora de lojas de roupa (temporárias e efetivas) e buscava exatamente esse tipo de trabalho. Já Fabiana (17 anos), que havia trabalhado como babá, queria um trabalho (que para ela era melhor), tal como o de vendedora, ou recepcionista ou operadora de telemarketing. As duas, que já tinham alguma experiência profissional, queriam trabalhar para custear suas despesas pessoais e ajudar na renda familiar, mas 
afirmaram que não sofriam grande pressão da família, que as estava apoiando nessa busca. A pressão maior era delas mesmas, que sentiam a necessidade de ter o próprio dinheiro e alcançar uma independência em relação à família. Fabiana estava acompanhada de um amigo que também procurava trabalho e foi quem sugeriu que eles fossem até às agências de emprego do Centro.

Juliano e Wellington, ambos de 19 anos e com curso médio já completo, são primos. Juliano já havia trabalhado na construção civil, como ajudante de obras, tanto formal, quanto informalmente. Wellington já havia trabalhado como vendedor e como professor de capoeira. Há dois meses eles haviam feito um curso profissionalizante para segurança e vigia, e, além de vagas nas áreas em que eles já haviam atuado, buscavam também trabalho na área de vigilância e segurança, pois, apesar de não terem experiência, acreditavam que o curso realizado poderia contar pontos nessa busca. Os dois precisavam colaborar na renda familiar com mais necessidade que Ana Maria e Juliana. Porém, eles estavam motivados a conseguir um "bom trabalho", um trabalho melhor do que os que eles tiveram, não pareciam dispostos a aceitar qualquer coisa. Os dois demonstraram grande interesse em ingressar na área de segurança e vigilância e esse interesse guiava suas buscas.

Rogério (19 anos) havia trabalhado anteriormente como estoquista de uma rede de hipermercados e como ajudante de obras. Agora, porém, ele procurava um "trabalho melhor"; queria trabalhar em escritório, loja ou call center, pois achava que, com o Ensino Médio completo, tinha chances para conseguir esse tipo de trabalho que antes ele não conseguiria. Ele não queria mais realizar um trabalho manual; estava em busca de um trabalho melhor por sua remuneração mais alta e que lhe proporcionasse possibilidade de crescimento. Rogério afirmou que não sabia que roupa usar na atividade de procura e disse que já havia pago pela elaboração de seu currículo.

Sandro (20 anos), apesar de razoavelmente jovem, tinha um amplo currículo na área de vendas e buscava um trabalho nessa área. Sua experiência e rede de contatos o faziam portador de um discurso bastante seguro e otimista, apesar de ser ele um pai de família (casado e com uma filha) e ter uma necessidade material maior que os outros desse grupo. Ele parecia saber como e onde procurar e não estava disposto a aceitar ocupação com remuneração menor que a que ele tinha antes.

Adriano (19 anos) também tinha um discurso seguro e otimista, não tanto por sua experiência, que não era tão vasta quanto a de Sandro, mas por sua qualificação. Ele já havia feito vários cursos de computação, fazia naquele momento um curso de Análise de Sistemas e cursava faculdade de Informática. Já havia trabalhado como técnico de informática e buscava apenas trabalho nessa área, de preferência em uma grande empresa, o que, segundo ele, fazia muita diferença no currículo. 
Adriano fazia uma busca bastante seletiva e focada em um tipo de ocupação específica. Além disso, era fundamental para ele que o trabalho não atrapalhasse seus estudos.

\section{Quadro4.2: Características dos demandantes do grupo de "Jovens adultos em busca de um} bom emprego"

\begin{tabular}{|c|c|c|c|c|c|}
\hline Nome & Moradia & Idade & Escolaridade & Profissão & O que procura \\
\hline Ana Maria & $\begin{array}{l}\text { Mandaqui } \\
\text { (Santana) }\end{array}$ & 19 & $\begin{array}{c}\text { E Médio } \\
\text { Incompleto } \\
\text { Está estudando. }\end{array}$ & Vendedora & Vendedora \\
\hline Juliano & Vila Matilde & 19 & $\begin{array}{l}\text { E Médio } \\
\text { Completo }\end{array}$ & $\begin{array}{c}\text { Ajudante de } \\
\text { obras }\end{array}$ & $\begin{array}{c}\text { Construção civil } \\
\text { Vigilante }\end{array}$ \\
\hline Wellington & Vila Matilde & 19 & $\begin{array}{l}\text { E Médio } \\
\text { Completo }\end{array}$ & $\begin{array}{c}\text { Professor de } \\
\text { capoeira } \\
\text { Vendedor }\end{array}$ & $\begin{array}{l}\text { Vigilante } \\
\text { Vendas }\end{array}$ \\
\hline Rogério & Pirituba & 19 & E Médio completo & $\begin{array}{c}\text { Estoquista } \\
\text { Ajudante de } \\
\text { obras } \\
\end{array}$ & $\begin{array}{c}\text { Estoquista } \\
\text { Escritório } \\
\text { telemarketing }\end{array}$ \\
\hline Fabiana & $\begin{array}{c}\text { Ermelino } \\
\text { Matarazzo }\end{array}$ & 17 & $\begin{array}{l}\text { E Médio incompleto } \\
\text { Está estudando. }\end{array}$ & Babá & $\begin{array}{l}\text { Recepcionista } \\
\text { Vendedora } \\
\text { Telemarketing }\end{array}$ \\
\hline Sandro & Osasco & 20 & $\begin{array}{l}\text { E Médio } \\
\text { completo }\end{array}$ & Vendedor & Vendas \\
\hline Adriano & Pirituba & 19 & $\begin{array}{c}\text { E Superior } \\
\text { incompleto } \\
\text { (informática) } \\
\text { Está estudando. }\end{array}$ & $\begin{array}{l}\text { Técnico em } \\
\text { informática }\end{array}$ & $\begin{array}{c}\text { Técnico em } \\
\text { informática } \\
\text { Ajudante de } \\
\text { escritório }\end{array}$ \\
\hline
\end{tabular}

Fonte: Levantamento de campo, 2009.

Por se acreditarem possuidores de alguma experiência e/ou qualificação, os integrantes desse grupo têm menos disponibilidade de aceitar qualquer tipo de trabalho. Ademais, por sua posição na família, pouco tempo de desemprego e/ou condição sócio-econômica familiar favorável, não apresentam a mesma urgência na obtenção de trabalho e renda dos próximos dois grupos. Nesse grupo é menor a premência da renda e de obtenção de experiência. Com exceção de Sandro, todos ainda moravam com a família e contavam com ela financeiramente, ainda que em alguns casos com alguma pressão para obtenção de trabalho.

Podemos dizer que os jovens desse grupo já passaram da fase do grupo anterior, onde a pouca seletividade é quase condição sine qua non para obtenção de um emprego. Aqui há uma certa seletividade de alvo, pois a procura é mais direcionada; os jovens buscam postos em que já têm alguma experiência ou qualificação, como no caso de Juliano e Wellington que fizeram curso para 
vigilante/ segurança e Adriano que fazia curso universitário no campo da informática e análise de sistemas. A experiência da procura é, portanto, mais delimitada, de forma a atender às expectativas profissionais de cada um deles. Ela é, ademais, pautada por expectativas de crescimento profissional.

Por outro lado, a procura de trabalho não lhes parece algo tão misterioso; dominam melhor alguns códigos e estratégias de procura, sabendo, por exemplo, onde é maior a oferta para as vagas que eles buscam e já possuem alguma rede de contatos que pode lhes oferecer informações sobre trabalho, como é o caso de Ana Maria, Wellington, Sandro e Adriano. Porém, a insegurança e as dúvidas quanto ao processo de procura também se fazem presentes nesse grupo e esse é um assunto tratado no ambiente familiar, mas, principalmente nas esferas de amizade e vizinhança. Aqui há também uma busca ativa de informações sobre esse tema em meios de comunicação diversos.

\subsection{Jovens adultos em busca de um emprego com urgência}

Esse é o grupo mais numeroso, composto por nove dos vinte e quatro entrevistados: Thiago, Édson, Walter, Ângela, Silvana, Ana Paula, Marcelo, Silmara e Carlão. A faixa etária aqui é mais larga, de 19 a 30 anos. Eles são, na média, mais velhos que os demandantes dos dois primeiros grupos e possuem escolaridade mais alta. Todos têm, pelo menos, curso médio completo, três deles estão cursando faculdade e um deles já é formado em curso superior. Cinco deles já constituíram família, sendo que Silvana e Ana Paula são casadas, mas não têm filhos, Walter é casado e tem filhos e Silmara tem filhos, mas não é casada. Eles possuem mais escolaridade, mais experiência de trabalho e mais responsabilidades no provimento da renda familiar do que os grupos anteriores; podemos dizer que, ainda que jovens, eles são mais "adultos" que os outros dois grupos. Alguns dos jovens desse grupo parecem enfrentar situações de necessidade material momentânea, outros, como Ângela, Walter e Marcelo, pelo que foi possível captar com as entrevistas, parecem provir de um meio social mais pobre e desfavorecido.

A maior característica dos demandantes desse grupo e o que mais os aproxima entre si é a urgência em arrumar trabalho. Isso por várias razões possíveis: i) possuem família constituída e lar e filhos para sustentar, ii) sua participação na renda familiar é fundamental, iii) não podem contar com uma rede de apoio familiar à sobrevivência no desemprego, iv) têm dívidas a saldar, v) enfrentam um período longo de desemprego e vi) mensalidade da faculdade para pagar. Todos os demandantes desse grupo enfrentam uma ou várias dessas situações citadas, o que os deixa mais vulneráveis à condição de desemprego e às necessidades materiais. Esses demandantes, apesar da razoável 
qualificação e experiência de alguns, não podem mais restringir ou selecionar sua busca, encontramse num momento em que a urgência em obter renda é o que rege a procura. A razão que os move até o cluster de intermediação da Rua Barão de Itapetininga é justamente o imaginário de que é fácil conseguir trabalho lá.

Thiago, Édson e Ana Paula enfrentam o problema do custeio do curso superior. Apesar do desemprego, têm que honrar as mensalidades. No caso de Thiago (19 anos), quem o ajuda é sua irmã mais velha, com quem ele mora. Ele gostaria muito de fazer um estágio na sua área, Contabilidade, mas estava disposto a aceitar ocupações fora desse ramo. Édson (23 anos) tem várias mensalidades de seu curso atrasado, pois seus pais não têm condições de arcar com esse custo. Por isso, ele que trabalhou quatro anos como caixa de banco, disse que estava "disposto a aceitar trabalho até de operador de telemarketing”, nas suas palavras. Ana Paula (26 anos), recém-casada, tem suas mensalidades pagas pelo marido, mas ambos se encontram endividados pelas compras de móveis e eletrodomésticos, feitas pós-casamento. Ela, que afirma que ganhava muito bem em seu último emprego de secretária, estava disposta a aceitar salários inferiores. Aqui, mensalidades e dívidas criam a necessidade de renda urgente, assim como a pressão gerada por familiares e cônjuge. Assim, eles estão dispostos a aceitar trabalho, mesmo que fora de sua área de formação e experiência anterior e com remuneração inferior. Em nome do investimento na qualificação, eles estavam dispostos a sacrificar momentaneamente o investimento em uma carreira profissional e aceitar qualquer trabalho. A obtenção de trabalho assume um caráter muito prático, o de possibilitar o pagamento de dívidas referentes ao ensino superior, o qual nenhum dos três queria abandonar.

Silvana (23 anos), que mora com seu namorado, precisa ajudá-lo nas despesas da casa assim como, mandar dinheiro para sua mãe que mora em Minas Gerais. Seu desemprego coloca em risco não só sua própria condição material, quanto a de sua família, que não pode apoiá-la e ainda necessita dela. Ela já tinha trabalhado como promotora de vendas em shoppings e supermercados, mas sua última ocupação foi como professora. Ela, que sonhava atuar nessa área, abria mão de seu sonho aceitando outros trabalhos pela necessidade material. Silvana tinha um discurso bastante desesperado e afirmou que já pediu dinheiro emprestado para agiotas. Ela estava acompanhada de seu namorado, que disse que estava tentando apóia-la nesse momento por saber que ela estava muito nervosa e ansiosa. Depois da procura, eles iriam passear, para "esfriar a cabeça".

Walter (29 anos) é casado, chefe de família e tem dois filhos. Sua experiência é como porteiro e vigilante, mas disse que aceitaria trabalhos "mais pesados", como manutenção, serviços gerais e limpeza, pois ele é o provedor da família e não pode contar com apoio material de sua rede familiar. 
A sua família parecia viver numa situação de pobreza, pois Walter narrou dificuldades financeiras, inclusive para comprar comida. Walter disse que todos os seus trabalhos foram obtidos através de indicação e que essa era a primeira vez que ele se via obrigado a recorrer às agências de emprego, situação da qual ele não gostava muito. Foi seu irmão quem fez o seu currículo e o estimulou a distribuí-los nas agências do Centro.

Silmara (30 anos) é mãe de dois filhos e os sustenta sozinha, com o apoio da aposentadoria de sua mãe. Ela é cabeleireira e manicure e faz bicos nessa área. Ela buscava trabalho na sua área de atuação, mas também aceitaria vagas como vendedora, recepcionista ou operadora de telemarketing, mesmo que pagasse menos do que ela ganhava como cabeleireira, contanto que fosse um trabalho registrado com remuneração fixa. Ela se sentia muito angustiada e vulnerável como cabeleireira autônoma e o que ela buscava realmente era um trabalho registrado e estável, com urgência e independentemente da área de atuação. Após o dia de procura no centro, Silmara iria aproveitar que estava naquele espaço da cidade para comprar os produtos de beleza que ela utiliza na prestação de seus serviços de cabeleireira e manicure, pois, ela disse “aqui os preços são melhores e há mais variedade".

Ângela (22 anos), Marcelo (24 anos) e Carlão (25 anos) vivem com suas famílias, mas sofrem muita pressão de seus pais e irmãos para arrumar trabalho. Nesse caso, a pressão é tanto para colaborarem na renda familiar, quanto para não ficarem "desocupados" em casa ou na rua, pois eles não estudam e do ponto de vista de suas famílias, já passaram da idade em que se é socialmente permitido ficar em casa. Marcelo e Carlão narraram conflitos com os familiares por esse motivo. Marcelo e Ângela pareciam possuir uma condição social bastante desfavorecida, sugerindo em seus discursos situações de pobreza, como dificuldades para comprar comida e pagar as contas mais básicas. Os três já se encontravam, em média, há mais de um ano, em situação de desemprego, não realizavam bicos e chegaram num momento de intensificação da procura e queda da seletividade, tanto para responder às pressões familiares, quanto para sair do desânimo e do insulamento na vida privada em que se encontravam.

Quadro 4.3: Características dos demandantes do grupo de "Jovens adultos em busca de um emprego com urgência"

\begin{tabular}{|l|l|l|l|l|l|}
\hline Nome & Moradia & Idade & Escolaridade & Profissão & $\begin{array}{l}\text { O que } \\
\text { procura? }\end{array}$ \\
\hline Thiago & Bela Vista & 19 & $\begin{array}{l}\text { Ensino Superior } \\
\text { incompleto } \\
\text { (contabilidade) }\end{array}$ & $\begin{array}{l}\text { Operador de } \\
\text { Telemarketing }\end{array}$ & $\begin{array}{l}\text { Telemarketing } \\
\text { Estágio em } \\
\text { contabilidade }\end{array}$ \\
\hline Edson & Freguesia do ó & 23 & Ensino Superior & Caixa de banco & Telemarketing \\
\hline
\end{tabular}




\begin{tabular}{|c|c|c|c|c|c|}
\hline & & & incompleto & & $\begin{array}{l}\text { Vendas } \\
\text { Ajudante de } \\
\text { escritório }\end{array}$ \\
\hline Walter & $\begin{array}{l}\text { Jardim Helena } \\
\text { (S. Miguel } \\
\text { Paulista) }\end{array}$ & 29 & $\begin{array}{l}\text { Ensino Médio } \\
\text { Completo }\end{array}$ & $\begin{array}{l}\text { Vigilante/ } \\
\text { Porteiro }\end{array}$ & $\begin{array}{l}\text { Vigilante } \\
\text { Porteiro } \\
\text { Limpeza } \\
\text { Serviços Gerais }\end{array}$ \\
\hline Ângela & Vila Alpina & 22 & $\begin{array}{l}\text { E médio } \\
\text { Completo }\end{array}$ & $\begin{array}{l}\text { Operadora de } \\
\text { máquina (setor } \\
\text { alimentício) }\end{array}$ & $\begin{array}{l}\text { Qualquer } \\
\text { trabalho }\end{array}$ \\
\hline Silvana & $\begin{array}{l}\text { Vila das } \\
\text { Mercês } \\
\text { (Ipiranga) }\end{array}$ & 23 & $\begin{array}{l}\text { E Superior completo } \\
\text { (pedagogia) }\end{array}$ & $\begin{array}{l}\text { Promotora de } \\
\text { Vendas } \\
\text { Professora }\end{array}$ & $\begin{array}{l}\text { Vendedora } \\
\text { Recepcionista } \\
\text { Escritório } \\
\text { Escola }\end{array}$ \\
\hline Ana Paula & Saúde & 26 & $\begin{array}{l}\text { E. Superior } \\
\text { incompleto } \\
\text { (administração) }\end{array}$ & $\begin{array}{l}\text { Secretária } \\
\text { Ajudante de } \\
\text { escritório }\end{array}$ & $\begin{array}{l}\text { Recepcionista } \\
\text { Secretária } \\
\text { Ajudante } \\
\text { escritório } \\
\text { Telemarketing } \\
\text { Estágio }\end{array}$ \\
\hline Marcelo & Casa Verde & 24 & E Médio completo & $\begin{array}{l}\text { Moto boy } \\
\text { Office-boy }\end{array}$ & $\begin{array}{l}\text { Moto boy } \\
\text { Office-boy }\end{array}$ \\
\hline Silmara & $\begin{array}{l}\text { Vila } \\
\text { Guilherme }\end{array}$ & 30 & E Médio completo & $\begin{array}{l}\text { Cabeleireira } \\
\text { Manicure }\end{array}$ & $\begin{array}{l}\text { Cabeleireira } \\
\text { Manicure } \\
\text { Vendedora } \\
\text { Telemarketing }\end{array}$ \\
\hline Carlão & $\begin{array}{l}\text { Vila Mascote } \\
\text { (Santo } \\
\text { Amaro) }\end{array}$ & 25 & E Médio completo & Segurança & $\begin{array}{l}\text { Segurança } \\
\text { Telemarketing }\end{array}$ \\
\hline
\end{tabular}

Fonte: levantamento de campo, 2009.

Esse é o grupo mais numeroso e variado, do ponto de vista do tipo de profissão, do tipo de ocupação almejada e das dificuldades enfrentadas, mas, como argumentado, a necessidade de superar a privação financeira imposta pelo desemprego é, por vários motivos, o que leva esses demandantes a uma procura menos seletiva e, até, em alguns casos, mais desesperada. O constrangimento social e familiar pode estar associado a essa questão material. Há um tom de derrotismo e de desânimo nos discursos que relatam essa "busca urgente". Perdido o domínio sobre a própria trajetória profissional e sobre sua própria re-inserção no mercado de trabalho, eles se rendem às oportunidades existentes, sejam elas quais forem. Esses demandantes são, em seu processo de procura, constrangidos por necessidades econômicas que eles não conseguem driblar, o que provoca angústia e cria a sensação de falta de autonomia sobre a própria trajetória, as quais pode-se tentar contornar através da busca freqüente de trabalho.

É interessante notar que nesse grupo há uma pressão familiar e um constrangimento social que os atinge e por vezes humilha, e que também se tenta minimizar através da procura ativa de trabalho. 
A busca sem sucesso é geralmente atribuída a fatores como injustiça em processos seletivos, falta de sorte e crise econômica, fatores esse exteriores aos indivíduos e por eles incontroláveis. Outra causa apontada algumas vezes foi a falta de compreensão dos códigos, atributos e habilidades exigidas pelo mercado de trabalho, entidade igualmente exterior ao demandante e incontrolável. Por mais que eles crescentemente dominem as práticas e os instrumentos básicos à procura, o que escapa à sua percepção, talvez por efeito do próprio insucesso nessa procura, é o "mercado de trabalho", tratado quase como uma entidade misteriosa.

A experiência da procura de trabalho, nesse grupo, está fortemente demarcada por constrangimentos econômicos e sociais dos demandantes que lhes criam dificuldades e pautam as suas expectativas de forma a criar impacto nas decisões que tomam sobre como e, principalmente, o que buscar. Essa experiência é marcada também por sentimentos como fracasso, humilhação e vergonha.

\subsection{Adultos em busca de um novo emprego.}

Esse grupo se caracteriza por englobar os quatro entrevistados mais velhos, aqueles quatro únicos entrevistados que possuem mais de 30 anos: Vera, Armando, Carmem e Miro. Eles se caracterizam também por possuir uma trajetória ocupacional mais longa e razoavelmente estável, principalmente em serviços manuais. A escolaridade mais baixa também caracteriza esse grupo de entrevistados. Os demandantes desse pequeno grupo parecem ser os que mais se aproximam de uma condição de pobreza.

Vera, 37 anos, casada, mãe de duas filhas e com curso fundamental completo, trabalhou muitos anos na indústria, como operadora de máquinas, mas seus trabalhos mais recentes foram na área de limpeza. Ela havia sido demitida há mais de um ano de um escritório, onde era responsável pela limpeza e manutenção; desde então fazia apenas bicos como faxineira diarista. Ela buscava um novo emprego, mas, para além da necessidade financeira e da urgência, ela também fazia questão de salientar que o que buscava ali era um trabalho registrado. Ela preferia trabalhar, mesmo que na área de limpeza, em estabelecimentos comerciais, pois não gostava de trabalhar em "casa de família"; e queria um emprego formal, pois tinha preocupação com a contribuição para sua futura aposentadoria. Ela havia recentemente começado a procurar trabalho em agências de emprego e foi uma de suas filhas que a ajudou a fazer o currículo e a escolher a roupa para procurar trabalho.

Armando, 43 anos, curso médio completo, é motorista. Já trabalhou como motorista de caminhão e motorista particular, mas seus últimos trabalhos foram com como motorista de firmas. 
Desempregado, não realizava nenhum bico no momento e buscava trabalho como motorista, mas aceitava "qualquer outro trabalho que aparecer". Divorciado e sem filhos, morava na casa do irmão mais velho. Ele sobrevivia do seu fundo de garantia e da ajuda de parentes. Já tinha procurado trabalho outras vezes na região da Barão, e achava que não iria conseguir nada. Mesmo assim, ele insistia em voltar lá, porque seria "melhor procurar do que ficar em casa", incômodo que se acentuava pelo falo dele morar "de favor" na casa de parentes.

Carmem, 50 anos e com curso fundamental completo, sempre trabalhou como costureira e bordadeira; aposentada por invalidez, ela buscava um trabalho que lhe ajudasse a complementar a renda. Fazia bicos como costureira, mas, devido a seus problemas de saúde, não podia mais trabalhar muitas horas na máquina de costura. O seu discurso era muito desesperançado e ela mesma disse que só estava ali "por desencargo de consciência", ou seja, para poder dizer para os outros, e para si mesma, que havia tentado.

Miro, 48 anos, casado e chefe de família, não chegou a completar o curso médio; é marceneiro, mas seu último trabalho foi como caseiro em uma chácara nas proximidades da cidade. Após um desentendimento com o patrão, foi demitido. Moveu uma ação contra o seu ex-patrão na Justiça do Trabalho, pois não recebeu todos os pagamentos que acreditava corresponderem a "seus direitos", e estava procurando trabalho como marceneiro ou na área de manutenção e serviços gerais. Miro, que é chefe de família, estava desempregado há mais de cinco meses e a urgência na obtenção de trabalho dava o tom de seu relato; mas ele estava otimista, pois já havia, há muitos anos atrás, conseguido trabalho, também na região da Barão, como marceneiro para um serviço por empreiteira.

\section{Quadro 4.4. Características dos demandantes do grupo dos "Adultos em busca de um novo} emprego"

\begin{tabular}{|c|c|c|c|c|c|}
\hline Nome & Moradia & Idade & Escolaridade & Profissão & $\begin{array}{c}\text { O que } \\
\text { procura? }\end{array}$ \\
\hline Vera & Interlagos & 37 & $\begin{array}{c}\text { Fundamental } \\
\text { completo }\end{array}$ & $\begin{array}{c}\text { Limpeza } \\
\text { Operadora de } \\
\text { máquina }\end{array}$ & Limpeza \\
\hline Armando & Arthur Alvim & 43 & $\begin{array}{c}\text { E Médio } \\
\text { Completo }\end{array}$ & $\begin{array}{c}\text { Motorista } \\
\text { Serviços gerais } \\
\text { Ou qualquer } \\
\text { outro trabalho }\end{array}$ \\
\hline Carmem & Jaguaré & 50 & $\begin{array}{c}\text { E fundamental } \\
\text { completo }\end{array}$ & $\begin{array}{c}\text { Costureira/ } \\
\text { Bordadeira } \\
\text { Aposentada }\end{array}$ & $\begin{array}{c}\text { Limpeza } \\
\text { Serviços Gerais }\end{array}$ \\
\hline Miro & São Bernardo & 48 & E Médio incompleto & $\begin{array}{c}\text { Marceneiro e } \\
\text { caseiro }\end{array}$ & $\begin{array}{c}\text { Marcenaria } \\
\text { Manutenção } \\
\text { Serviços gerais }\end{array}$ \\
\hline
\end{tabular}


Fonte: Levantamento de Campo, 2009.

A busca por um novo trabalho se mostrava mais penosa para esse grupo do que para os demais. Carmem e Armando demonstraram falta de esperança e descrédito na sua própria atividade de procura. Vera e Miro, por outro lado, apesar de oferecerem discursos um pouco mais esperançosos, demonstraram mais desespero e urgência na obtenção de uma renda, pela configuração de suas famílias e papel central que eles assumem no provimento da renda familiar. Vemos, assim, que a conduta na procura reflete, em importante medida as características dos meios sociais dos demandantes. Diferentes contextos sociais, e diferentes posições nesses contextos, produzem dificuldades e expectativas diversas e engendram experiências de procura marcadas por sentimentos e significados também distintos. Esse elemento constitutivo das experiências sociais pode influenciar também a vivência da situação de procura estudada.

Mas não só atributos e contexto influenciam a conduta na pesquisa. Apesar da grande experiência ocupacional que os entrevistados desse quarto grupo possuem, podemos observar que há, exceto no discurso de Miro, aquele que já havia obtido trabalho ali uma vez, uma falta do domínio das práticas e códigos necessários à procura de trabalho por meio das instituições de intermediação de mão-de-obra. E, paradoxalmente, nesse grupo onde os componentes são os mais velhos da amostra de entrevistados, e de forma semelhante ao grupo dos primo-demandantes, onde estão os mais jovens da amostra, a procura, nesses moldes, também é uma experiência nova. Porém, entre os mais velhos, essa é uma aprendizagem mais difícil e dolorosa. A construção de uma conduta de demandante é um processo que passa por práticas que eles não precisaram realizar para conseguir a maioria de seus trabalhos anteriores, obtidos por meio de contatos pessoais. Vemos, assim, que a conduta de demandante de trabalho não está, necessariamente, relacionada à conduta ou identidade de trabalhador, pois pode passar por processos que não são aprendidos na prática do trabalho, mas em outras dimensões da vida social, como pretendemos explorar no item a seguir.

Os possíveis delineamentos de tipos de experiências de procura que apresentamos estão baseados nas informações que puderam ser captadas. Uma série de características sociais que podem influenciar na configuração dessas experiências podem ter escapado à investigação. Então, ressaltase que os tipos de experiências apresentadas acima são construídas com base em algumas das características sociais dos demandantes, as quais foram possíveis captar, e são, antes, um exercício exploratório de análise desses dados. Seguimos esse exercício exploratório através de outro 
elemento constitutivo da experiência da procura de trabalho: seus elos com outras vivências e sociais dos demandantes.

\section{A procura de trabalho e as outras dimensões da vida social}

Vimos que a experiência da procura de trabalho é condicionada pelas características sociais dos demandantes. A diferentes tipos de demandantes estão associadas diferentes experiências de procura, pois baseadas em expectativas e dificuldades também diversas, e essas podem produzir distintas formas de vivência de uma situação de procura, como a que foi investigada.

Mas as experiências de procura podem se diferenciar também pela forma como essa atividade está (ou não) articulada a outras dimensões da vida social do demandante, sendo esse um outro elemento constitutivo da experiência social de procura de trabalho.

Os discursos colhidos em campo permitiram perceber que essa articulação da vivência da procura de trabalho com outras vivências e outras dimensões sociais pode se dar por duas vias. $\mathrm{O}$ primeiro tipo de articulação possível é aquele que se estabelece entre vivências sociais precedentes ao processo de procura e em outras dimensões da vida social, os quais acabam por interferir na produção múltipla da conduta do demandante na situação de procura. Nesse ponto nos referimos aos processos sociais de aprendizado, troca e incorporação de códigos e regras referentes à procura. A segunda forma identificada de articulação da vivência da procura com outras dimensões é aquela que se dá através do estímulo de outras vivências sociais, vindas da própria atividade de procura. No primeiro caso buscamos entender como outras vivências sociais refletem na procura; no segundo buscamos entender como a procura gera outras vivências, sendo que essas podem estar relacionadas a diferentes dimensões da vida social.

Ambas as formas de articulação que podem ser estabelecidas entre a vivência da situação de procura e vivências em outras situações e dimensões sociais são indícios das articulações imprecisas, mas constitutivas da experiência social da procura de trabalho. É certo que outras formas de articulação podem ter sentido, mas essas foram as que os discursos colhidos nos permitiram captar, e as quais se explora com a intenção de prosseguir na compreensão dos elementos constituintes da experiência da procura.

\subsection{Conduta social do demandante de trabalho: construção múltipla}

A conduta do demandante de trabalho é muito peculiar e marcada por um conjunto de códigos e práticas que se expressam na forma de falar, de se vestir, de se portar. Ainda que essa conduta seja 
situada e seja também, em parte, construída na situação, há uma série de códigos relativos à demanda de trabalho que se deve conhecer antes de começar o processo. Isso porque esses códigos não são naturais, são socialmente construídos e seu aprendizado não constitui um processo trivial, já que não se aprende esse tipo de ensinamento na escola e nem no trabalho. Há tanta dificuldade na composição dessa conduta que alguns serviços são procurados para preencher essas lacunas, tal como mostramos no capítulo anterior, onde apresentamos os serviços correlatos à procura que acabam por facilitar e até realizar essa atividade para os demandantes. Parte dos códigos e instrumentos básicos à procura pode ser adquirida no curso do próprio processo, mas não exclusivamente. $\mathrm{O}$ que os discursos permitiram perceber é que essa é uma construção que não se dá em uma ou outra dimensão da vida social, mas em várias, reforçando a idéia de que é uma construção múltipla.

Sabe-se, há um conjunto de códigos básicos indispensáveis ao bom demandante de trabalho. Esse conjunto geral de códigos, claro, deve ser articulado às exigências específicas de cada vaga, como determinada escolaridade, formação e experiência anterior. Esses aspectos, citados tanto por funcionários de agências quanto por demandantes no capítulo anterior, serão rapidamente sistematizados na seqüência, quando tentaremos explicitar as dúvidas e dificuldades que esses códigos suscitam, tanto quanto as dimensões sociais por meio das quais eles podem ser transmitidos, trocados e aprendidos.

O processo de julgamento de um demandante começa pela aparência. Essa pode ser julgada tanto pelos atributos físicos de cada um (altura, peso, cor, traços do rosto e tipo de corpo) quanto pela vestimenta. É importante que o demandante se encaixe, pelo menos minimante, nos padrões de beleza vigentes e que esteja bem vestido. No que diz respeito aos atributos físicos, é sabido que há muita discriminação; são consideradas fora desses padrões estéticos considerados aceitáveis pelos recrutadores (que via de regra arguem o crivo do empregador para estabelecê-los) tipos físicos como: pessoas com sobrepeso, pessoas com manchas, machucados ou cicatrizes na pele e pessoas com falhas na arcada dentária, entre outras características. O trabalho de campo pode coletar discursos sobre esse tipo de discriminação, tanto formulados por aquele que discrimina, quanto por quem é discriminado. Uma selecionadora assumiu que não seleciona candidatos acima do peso ou com dentes mal cuidados. Por outro lado, uma demandante entrevistada acreditava que a razão da sua dificuldade em conseguir trabalho estava associada ao seu excesso de peso; disse ela, "entre uma magra e uma gorda, vão sempre escolher a magra". Um outro jovem entrevistado disse que sentia preterido nos processos seletivos por causa das queimaduras que possuía nas mãos e braços. Tanto 
discursos quanto a literatura sobre mercado de trabalho também indicam que a cor é um quesito determinante na seleção de candidatos.

Além dos atributos físicos, há muito julgamento envolvendo a vestimenta. Antes de sair para procurar trabalho ou para participar de um processo seletivo, todo demandante tem que enfrentar a tarefa de escolher a roupa mais adequada. Essa escolha pode envolver tempo, empréstimo de amigos e parentes e até compra de roupa nova. Há, portanto, uma "roupa de procurar trabalho", que é mais especial e não é necessariamente o mesmo vestuário utilizado no dia-a-dia de trabalho da ocupação pretendida. $\mathrm{O}$ cuidado com os cabelos também é citado como importante na composição da imagem, tanto para homens como para mulheres. A preparação do figurino representa o primeiro passo para a encarnação do personagem, e, sem dúvidas, a vestimenta e a aparência, tão minuciosamente preparadas, podem indicar se o candidato domina ou não os códigos que dele se espera. A dimensão da "apresentação de si" é complementada com a apresentação de um "bom currículo", o qual deve seguir as exigências descritas no capítulo anterior.

A boa oratória ou a habilidade para expressão verbal constituem outro item básico do bom demandante de trabalho, habitualmente referido como a "boa comunicação". O demandante de trabalho deve saber apresentar-se, falar de forma confiante e desinibida sobre si mesmo e sobre temas propostos tanto para selecionadores quanto para outros candidatos que com ele concorrem. A capacidade de expressar opiniões, bem como o uso adequado da língua são habilidades consideradas fundamentais por quem recruta. E, novamente, esse é o tipo de habilidade que não é natural; tal postura comunicativa e desinibida é muito difícil de ser incorporada, até mesmo porque o processo de procura pode gerar sentimentos de insegurança. Esse elemento da postura do "candidato ideal" gera muita dificuldade para ser incorporado à performance já que muitas pessoas são tímidas e ficam nervosas ao falar em público, mesmo se em pequenos grupos, ou para falar em situações críticas. Ademais, a fluência e o conforto requerem um repertório que é parte de um capital cultural construído em meios sociais bastante específicos e mais das vezes distintos ao meio de origem do demandante típico que recorre às agencias do Centro. Por isso mesmo, os eles tentam criar estratégias para driblar essa dificuldade, ensaiando discursos e formas de se apresentar e até mesmo decorando frases de efeito para utilizar nessas situações, conforme depoimento de Sandro (20 anos) e Silmara (30 anos). Essa preparação da fala é um recurso muito comum e ajuda a compor o personagem que, como argumentamos desde o inicio e gradativamente vemos com mais clareza, é multiplamente construído. 
Além dos elementos que qualificam a apresentação visual do demandante e a sua apresentação oral, há um conjunto de impressões subjetivas que qualificam sua personalidade: seriedade, comprometimento e segurança são as mais citadas pelos selecionadores. É fundamental que o demandante de trabalho demonstre nos seus gestos, atitudes e palavras que possui tais virtudes. Esses elementos são positivamente considerados pelos selecionadores, que criam estratégias para capta-los e analisa-los. Porém, como demonstrar durante poucos minutos que a pessoa é séria, comprometida e segura? Tais códigos de conduta são, sem sombra de dúvida, os que mais dependem do entendimento subjetivo do selecionador, sendo, por isso mesmo, aqueles que os demandantes têm mais dificuldade de incorporar à atuação de seu personagem.

Vê-se, assim, que há, na construção desse "personagem", muitos e complexos componentes. Muitos informantes afirmaram que não sabiam exatamente o que o mercado de intermediação esperava deles. A idéia do improviso e do "tentar se virar" nos processos seletivos foi muito freqüente nos discursos. Demandantes com boa escolaridade, tanto quanto demandantes com longa trajetória de trabalho, afirmaram não dominar completamente os códigos dessa conduta, o que reforça a idéia de que não é no trabalho nem nas instituições de ensino que eles são aprendidos. Mas, então, fica a pergunta: como aprendê-los?

É verdade que o próprio processo de procura pode proporcionar o contato com os códigos e expectativas que giram em torno dos demandantes de trabalho. Não só a busca de serviços correlatos à procura, mas também a observação dos outros demandantes podem oferecer muitas pistas para esse processo de aprendizagem. A socialização no contexto de interação, no seu sentido amplo, que caracteriza a situação de busca de trabalho, parece ser condição decisiva para a construção adequada do personagem e, sobretudo, para o desenvolvimento da capacidade de negociar a sua performance em ato. Após participar de muitas entrevistas e dinâmicas de grupo, um demandante pode captar a lógica e a linguagem que regem esses processos na prática. Alguns demandantes, após muitas experiências de procura de trabalho e em processos seletivos, podem passar a compreender a linguagem e a conduta típica desse tipo de situação e não seria exagero falar que podem se tornar verdadeiros "mestres da procura". Seguindo esse raciocínio, aqueles que passaram por poucas dessas experiências, como os primos-demandantes, podem ser chamados de "aprendizes da procura”. Isso pode sugerir que procurar trabalho se aprende procurando, o que, em parte, é verdade, já que quanto maior a intimidade com uma situação, maior o domínio dos códigos. Mas os relatos sugerem também que essas informações e códigos são incorporados também, e 
principalmente, através de outras formas de aprendizado, como a convivência e a troca de experiências com amigos e família e o contato com meios de comunicação diversos.

A família é um espaço social onde circulam os ensinamentos de códigos sociais os mais diversos. No que se refere aos códigos acionados na procura de trabalho não é diferente. Pais, mães e irmãos assumem parte desse processo de transmissão de códigos aos jovens e, muitas vezes, dividem também a responsabilidade da realização de parte do próprio processo de procura, fazendo currículos, comprando roupas adequadas à procura, indicando os locais para procurar trabalho e dando dicas sobre comportamento em entrevistas e dinâmicas. Os pais e irmãos mais velhos acompanham de perto a experiência da procura de seus filhos e irmãos mais novos. Ademais, pela relação de intimidade que sustenta o processo interativo, a família é um espaço em que o jovem pode fazer perguntas e mostrar suas dúvidas e inseguranças sem tanto desconforto; até porque procurar trabalho é um valor e, nesse sentido, da perspectiva da família, muito provavelmente ter duvidas sobre tal empreendimento e procurar solvê-las para se qualificar, uma indiscutível virtude. Não sem razão, são recorrentes os achados de pesquisas anteriores em que se relata que os jovens se sentem premidos pela família, depois de uma certa idade e, especialmente, em certas classes sociais, a buscar trabalho, a deixar a rua, a mostrar que pode ser capaz de deslanchar o seu processo de autonomizacão de status, diríamos com a literatura (Demazière, Guimarães e Sugita, 2006; Tartuce 2007-b) No nosso trabalho de campo esse tipo de relato também se fez presente e foi especialmente marcante nos discursos dos jovens Juliana (17 anos), Rogério (19 anos) e Fabiana (17 anos). Além disso, é comum que familiares façam papel de acompanhantes dos demandantes, acompanhando o processo, oferecendo apoio emocional e dicas in loco, ao longo do próprio processo de procura, tal como também encontrado por Tartuce (2007-b).

Porém, os filhos também podem ser os responsáveis pela transmissão desses códigos aos pais, como pude flagrar em campo, no caso de Mara (37 anos), que estava em busca do primeiro emprego, não conhecia os códigos da procura e, por isso, fazia sua busca acompanhada do filho e do sobrinho, Juliano e Wellington, ambos de 19 anos. Isso pode ser especialmente verdadeiro também para adultos que praticaram, ao longo de sua trajetória ocupacional, a procura de trabalho através de jornais, contatos pessoais e aplicação direta e que não dominam os códigos da procura em meios institucionalizados, tais como internet e agências de intermediação de mão-de-obra. Nesses casos, os filhos jovens que estão vivendo ou já viveram esse tipo de procura encarnam o papel de canal de transmissão de informações, as quais eles podem ter aprendido em outros meios sociais. A transmissão dos códigos de conduta do demandante na dimensão social da família se mostrou 
especialmente importante para os demandantes do grupo 1 que, além de serem primo-demandantes, são, com exceção de Mara, muito jovens e moram com a família, que acompanha e se interessa pelo processo de procura. No caso dos demandantes do grupo 2 a família também se mostrou um espaço de aprendizado importante, embora com menor intensidade do que no grupo 1. Mas, é importante registrar que, nesses dois casos, a família pode ser, além de um espaço de apoio, também um espaço de cobrança e de constrangimento.

Talvez por isso, apesar do papel socialmente legítimo de transmissora de códigos sociais e culturais que a família assume, a convivência e troca de informações entre amigos foi a forma mais apontada pelos jovens por sua importância no processo de aquisição de códigos, conhecimentos, e informações sobre procura de trabalho. Esse achado pode ser especialmente significativo para o grupo de demandantes que procuram trabalho naquele cluster de intermediação, já que lá a maioria é composta por jovens. Essa troca de experiências que se dá informalmente entre amigos, colegas, vizinhos e namorados tem um papel muito forte no processo de incorporação dos códigos constituintes da conduta do demandante de trabalho e se mostrou muito significativo nos relatos. Os discursos mostram que os amigos narram uns para os outros suas experiências de procura de trabalho, contando detalhes sobre as entrevistas e as dinâmicas. Assim, os jovens tomam conhecimento sobre esse universo de códigos através da experiência do outro e discutem entre si sobre qual a melhor roupa para usar nessa situação, o que falar, como se portar. Livres da pressão que a família pode exercer para a obtenção de um trabalho, entre amigos essas conversas adquirem um tom mais informal, de troca, onde um pode aprender com o outro. É muito comum também amigos saírem para procurar trabalhos juntos; pegar roupa e até mesmo dinheiro emprestado, dividindo, de fato, essa experiência. Elisa (18 anos) estava procurando trabalho com duas vizinhas, Fabiana (17 anos) estava acompanhada de um amigo que também buscava trabalho e Silvana contou com a companhia do namorado. A esfera das amizades se mostrou muito importante nos relatos dos demandantes de três dos quatro grupos apresentados acima, os grupos 1, 2 e 3.

Os meios de comunicação como internet, televisão e revistas também foram muito citados como fontes de informação e conhecimento sobre os códigos necessários à conduta de um bom demandante de trabalho. Os jovens, em especial, demonstraram interesse por programas e reportagens que tocassem nesse tema e alguns afirmaram procurar ativamente dicas e informações a esse respeito em sites da internet ou em revistas especializadas. A busca por guias ou manuais de procura de trabalho em bancas de revista foi também citada. Um quadro que foi ao ar por uns meses num famoso programa veiculado na TV aos domingos, $O$ Fantástico, também foi várias vezes 
citado como fonte de informação sobre procura de trabalho. Isso pode ocorrer pela falta de um interlocutor próximo, ou seja, de um amigo ou parente, com quem possa trocar experiências, pedir informações e fazer perguntas sobre esse tema. O papel dos meios de comunicação na transmissão de códigos e dicas sobre procura de trabalho foi, assim, um outro achado, tendo sido foi citado por demandantes de todos os quatro grupos.

Mas, além disso, os discursos permitiram perceber que há uma necessidade de buscar ajuda “especializada", pois a conduta de demandante de trabalho corresponde também a um conjunto de representações e expectativas que está baseado em discursos criados no domínio da gestão de recursos humanos. Esse domínio especializado tem um discurso muito próprio e poderoso sobre as práticas de seleção de candidatos e sobre a construção da imagem do bom candidato. Porém, esse é um universo muito distante da grande maioria das pessoas e mesmo dos trabalhadores. Assim, as representações sociais do bom candidato engendradas nesse meio não chegam de maneira direta até os atores sociais, mas são transmitidas através de livros, revistas, reportagens, consultorias, etc. A falta de compreensão dos códigos e das práticas da gestão de recursos humanos e a curiosidade e a disponibilidade de tentar apreende-los através de pesquisas, livros, revistas e reportagens constituem um achado interessante dos discursos de alguns informantes, principalmente daqueles dos grupos 2 e 3.

A conduta de comportamento desempenhada por uma pessoa à procura de trabalho é, portanto, construída também a partir da vivência de outras dimensões da vida social, onde esses códigos podem ser observados, aprendidos, discutidos e trocados. A construção da conduta social do demandante de trabalho é, portanto, múltipla e constante. É múltipla à medida que os códigos que a constituem são incorporados através da vivência de diversas situações e dimensões sociais, não só da situação de procura de trabalho; e constante porque a cada novo código incorporado há uma reconfiguração dessa conduta como um conjunto. Tal conduta é também fruto da reformulação que lhe é aposta no desempenho de cada ator, pois, como bem destacam os interacionistas, há sempre, na encenação dos personagens sociais, espaço também para a re-interpretação e manipulação do léxico social.

A cada uma das situações sociais em que os atores participam corresponde uma conduta social específica, mais ou menos definida por um conjunto de códigos e práticas referentes ao papel que cada ator desempenha naquela situação. Ao papel de aluno corresponde um conjunto de comportamentos e expectativas, por exemplo. Idem para o papel de pai, para o papel de trabalhador, para o papel de cliente, e assim por diante. Para o desempenho adequado de alguns desses papéis 
sociais há um longo período de socialização com os códigos e práticas que lhes dizem respeito. Além disso, alguns desses papéis são desempenhados com mais frequiência ou por maiores períodos de tempo, facilitando, assim, a compreensão e a incorporação dos referentes códigos de conduta. A conduta de demandante de trabalho, no entanto, está associada a um papel social que (até mesmo socialmente e pelo modo como normatizado o desemprego, é entendido como sendo um papel que) só eventualmente é desempenhado e para o qual não há, habitualmente, um longo processo de preparação cognitiva. Assim, ao se deparar com a necessidade de enfrentar a procura de trabalho e assumir uma conduta condizente à essa situação, as pessoas enfrentam muitas dúvidas, dificuldades e insegurança. O papel de demandante de trabalho pode ser especialmente difícil de ser adequadamente desempenhado porque, como sugerimos, não há um processo longo de familiarização e sociabilização com os códigos que o regem e porque esse é um papel muito transitório e eventual, que é encarnado apenas em momentos e espaços muito circunscritos. Cientes da falta de domínio desses códigos, os demandantes têm muita curiosidade e muita vontade de desvendá-los e, por isso, buscam formas diversas de preencher essa lacuna em outras dimensões da vida social. A necessidade de conversar sobre esse processo com amigos e parentes e o interesse em buscar ativamente informações a esse respeito são indícios disso. Pela ausência de uma dimensão social privilegiada para a transmissão das regras e códigos da composição dessa conduta, ela é uma conduta múltipla, resultado de vivências em diversas dimensões sociais.

Por fim, é importante ressaltar que a incorporação da conduta do demandante, que é fruto de um processo múltiplo, pode ser e, na grande maioria das vezes é, um processo difícil, cheio de dúvidas, incertezas e incompreensões, mesmo que compartilhado com amigos e parentes, como deixaram explícitos os discursos. Ainda mais, o julgamento constante dessa conduta gera insegurança e medo. Uma dinâmica de grupo, por exemplo, pode gerar nervosismo, gagueira, suor excessivo e até tremedeira em um demandante de trabalho. O mercado de trabalho, visto pela ótica daqueles que acorrem ao mercado de intermediação de mão de obra, é tratado como uma entidade misteriosa e distante, que é regido por códigos que os demandantes não dominam muito bem. Assim, mesmo que a importância do mercado de intermediação de mão-de-obra tenha aumentado tanto para as empresas, quanto para os demandantes, pode-se dizer que ele é um domínio que opera por a um novo conjunto de regras e códigos que escapam a esses últimos, os quais, portanto, nutrem por tal conjunto de códigos, sensações ambivalentes de curiosidade e medo. Desse ponto de vista, a experiência da procura de trabalho pode assumir, e via de regra assume, uma faceta dolorosa. 
Porém, como será argumentado em seguida, essa experiência também assume uma dimensão simbólica muito positiva.

\subsection{A experiência da procura de trabalho: uma experiência múltipla}

Ainda que o deslocamento até o Centro seja estimulado pela necessidade de buscar trabalho, pudemos perceber que a experiência de procura pode estimular outras experiências sociais, todas parte de um entorno social mais amplo, de interface com a "membrana" que define os contornos da situação de procura, e que dizem de aspectos específicos da própria experiência urbana, dentre os quais destacaria três delas: a experiência de lazer, a experiência de consumo e a experiência da vida pública.

Estar naquele espaço da cidade é uma oportunidade para desenvolver outras atividades e vivenciar outras experiências a ele associadas, além da experiência de procura; mesmo se esta é urgente, mesmo se é emocionalmente central e mesmo se mostra socialmente decisiva. Com efeito, acabamos de documentar que a forma pela qual um demandante de trabalho vive a situação de procura é determinada também por vivências precedentes àquela situação e realizadas em outras dimensões sociais. Vamos tentar mostrar agora que outras vivências sociais podem ser construídas a partir da própria vivência da situação de procura. Assim, argüiremos que esta ultima deve ser também encarada como fruto de uma articulação imprecisa entre vivências que se dão antes, durante e após a atividade de procura propriamente dita. Os relatos dos demandantes nos permitiram indicar algumas delas, construídas na própria situação de procura de trabalho, e outras a partir dela, das quais trataremos em seguida.

Os demandantes de trabalho que acorrem ao mercado de intermediação instalado naquele território de procura, vêm dos mais diversos e até longínquos lugares da metrópole, realizando um deslocamento espacial que já é uma experiência em si mesmo. Deslocar-se da periferia ou de outras cidades da região metropolitana até o Centro não é uma tarefa trivial, e nem sempre é uma tarefa fácil, apesar do acesso facilitado pela ampla gama de meios de transporte público. Tal tarefa exige dinheiro para o transporte, paciência para enfrentar a superlotação dos mesmos, tempo, já que o deslocamento pode levar horas, e disposição, já que a distância pode exigir que se saia de casa tão cedo, antes mesmo que tenha clareado o dia.

O deslocamento periferia-centro está impregnado de significados. Há nesse processo uma mudança brusca de ambiente social. O Centro da cidade contrasta muito, do ponto de vista 
arquitetônico, urbanístico e simbólico, com os bairros e, principalmente, os bairros periféricos, de onde vem a grande maioria dos demandantes entrevistados.

A idéia de centralidade está expressa também na noção, tão difundida no senso comum, de que no Centro da cidade é possível se encontrar "de tudo", tanto no que se refere a serviços, produtos e atividades de lazer, quanto no que se refere à tipos de pessoas. O Centro concentraria o mais numeroso e variado conjunto de pessoas possível, do ponto de vista sócio-econômico e cultural, possibilitando àqueles que o freqüentam uma experiência de contato com o outro e de contato com a multiplicidade social e cultural.

Essa experiência pode extrapolar, e extrapola em muito, os limites da experiência da procura de trabalho. Ela é também uma experiência urbana, pois é uma experiência de deslocamento espacial e de re-localização simbólica. Assim é que entendo o que alguns informantes afirmaram quando diziam gostar de estar no Centro e das sensações que aquela experiência da cidade lhes propiciava. Podiam ver outros ambientes, conhecer lugares novos, "ver gente", viver a agitação típica daquele espaço, entre outros. Essa experiência urbana pode adquirir significados especialmente importantes dentro da experiência da procura de trabalho à medida que propicia também outros tipos de vivências sociais.

De acordo com relatos dos informantes, podemos afirmar que é comum que os demandantes aproveitem a oportunidade de "estar no Centro", para realizar outras atividades. Dos 24 entrevistados, 16 afirmaram que realizaram ou iriam realizar outra atividade no Centro além da procura de trabalho. Significativamente, a mais citada dessas atividades foi o passeio e o lazer, mencionada por oito entrevistados. Tendo em conta que todos os demandantes entrevistados se encontravam em situação de desemprego, tão caracterizada pelo insulamento domiciliar e isolamento social, esse simples passeio pela cidade pode adquirir um significado simbólico e surtir um efeito psicológico positivo, que são prenhes de importância e significado subjetivo.

Para eles, a idéia de que um dia de procura de trabalho pode ser também um dia de passeio não só é muito comum, como e está relacionada à idéia de que a atividade da procura de trabalho tira o desempregado do insulamento na vida privada e o traz à vida pública, vestido não com o pesado estereótipo de sem-trabalho, de desempregado, mas com a honrosa feição de batalhador, de demandante de trabalho.

Ademais, "Ver gente", "passear”, “conhecer lugares novos” e sentir a agitação e efervescência daquele espaço são sensações importantes à medida que contrastam com a monotonia da vida doméstica. Assim, esse deslocamento na cidade até o Centro parece adquirir um sentido de 
deslocamento da vida privada para a vida pública. Essa experiência de lazer pode trazer uma dimensão de prazer a uma atividade impregnada de sensações difíceis e dolorosas, como exploramos no item anterior, e pode, assim, propiciar uma vivência da dimensão pública da vida social.

A segunda atividade mais citada dentre aquelas que se pode realizar no Centro, antes ou depois da procura é o consumo, mencionada por sete dos entrevistados. Do ponto de vista econômico, o deslocamento até o Centro pode proporcionar o acesso a uma aglomeração apreciável de equipamentos, serviços e produtos típicos da região central da cidade e não só ao mercado de intermediação de mão de obra e aos serviços a ele correlatos. Assim, a ida até o Centro para procurar trabalho pode ser, e muitas vezes é, atrelada a outras atividades econômicas. A variedade de produtos e, principalmente, de preços é um grande atrativo do comércio do Centro, que contrasta com o daqueles pólos comerciais das regiões periféricas da cidade, as chamadas "centralidades periféricas". Além do mais, o comércio popular da região Central é muito grande e consolidado, atraindo consumidores das mais diversas regiões da metrópole, para não dizer de todo o Estado. A região da Rua Vinte e Cinco de Março, por exemplo, atrai consumidores de todo o país. Mais ainda, o Centro concentra espaços especializados em determinados produtos e serviços, a exemplo do mercado de intermediação de mão de obra. Outros bons exemplos são a Rua Conselheiro Crispiniano (travessa da Rua Barão de Itapetininga), especializada em artigos fotográficos e as galerias próximas à região da Rua Barão de Itapetininga, como a Galeria do Rock e a Galeria do Rap que atraem jovens das mais diversas regiões da cidade, em busca de lazer e consumo de artigos musicais.

Um tipo de consumo bastante citado pelos demandantes foi aquele de bens que são mobilizados na procura de trabalho, como pastas (para guardar currículos) e, principalmente, vestimentas e acessórios para os momentos de procura de trabalho. A imagem de si é cuidadosamente elaborada e, todos os elementos que possam ajudar a compor essa imagem da forma que se julga mais adequada, podem ser alvos de consumo; estes estão à mão e a bom preço no Centro, o que pode ajudar a reduzir o custo do investimento tanto na procura de trabalho, quanto a minimizar custos da sobrevivência no período de desemprego. A compra de produtos que possam ser utilizados em alguma atividade de geração de renda também foi citada; assim, a compra de mercadorias para uma posterior revenda é uma possibilidade, tanto quanto de matérias-primas para artesanato (como citado pela informante Mara), ou de materiais usados na prestação de serviços autônomos (como o exemplo de uma outra entrevistada, Silmara, que fazia bicos como manicure e cabeleireira e comprava ali os produtos necessários, como cremes, xampus e esmaltes). 
Mas, além do consumo ligado à procura e à geração de renda, outros itens e serviços também são buscados. Aproveita-se o deslocamento feito até o Centro para a compra de artigos que ali se encontram em maior variedade e a melhores preços. A experiência de consumo no Centro pode estar associada, assim, tanto à geração de renda, quanto à intenção de aproveitar as vantagens do comércio ali estabelecido.

A resolução de pendências e problemas da vida prática é uma terceira possibilidade de atividade que costuma ser realizada antes ou depois da procura de trabalho no centro da cidade. Solicitação e regularização de documentos (há um posto do Poupatempo na Sé), consulta a advogados ou médicos que anunciam ali seus serviços, venda de bens pessoais e pedidos de empréstimo foram algumas das atividades citadas pelos demandantes. O empenho na resolução de questões de ordem prática da vida pode ajudar a minimizar as sensações de ócio e inutilidade que também estão frequentemente associadas à situação de desemprego.

A relação dos demandantes de trabalho com o espaço estudado extrapola, assim, os limites da atividade de procura, e, por outro lado, soma à experiência da procura outras vivências sociais que a tornam mais cheia de significados, como se explicitará no próximo item. Quanto mais experiências sociais a atividade de procura produza, mais significados sociais a experiência de procura passará a adquirir para um demandante. A vivência da procura na situação investigada é pautada por experiências de aprendizagem e troca realizadas em outras dimensões da vida social, mas também cria outras vivências, como exploramos aqui. Estas podem engendrar novos significados sociais para a experiência da procura, como apresentaremos no item a seguir.

\section{Os significados da procura de trabalho}

A cada experiência social corresponde um conjunto de significados sociais. O território dos significados e representações sociais pode ser considerado como aquele onde se dá a construção subjetiva do real, onde se articulam fenômenos sociais e experiências individuais. Foi possível perceber que existem alguns significados, representações, idéias e sentimentos que podem ser associados à experiência da procura de trabalho.

A seguir apresenta-se esse conjunto de elementos recolhidos dos discursos sobre a experiência da procura de trabalho, de modo a interpretar as interpretações dos indivíduos sobre suas próprias experiências. Isso, pois seguindo ainda a tradição interacionista, ela mesma influenciada pela perspectiva weberiana, a idéia é fazer um esforço intelectual de capturar o significado que o próprio 
ator confere às suas ações e experiências, ou seja, investir no trabalho de interpretar a interpretação dos atores. Para tal, parte-se da concepção de que as categorias "desempregado" ou "demandante de trabalho" são, elas mesmas, fruto de construções sociais e, nesse sentido, se faz necessário compreendê-las a partir das representações que lhe são associadas e que, por isso mesmo, são coletivamente reconhecidas e individualmente re-elaboradas.

Os discursos sobre esses significados sociais foram colhidos ao longo do próprio processo de procura, ou seja, no momento em que eles eram vividos e elaborados pelos demandantes. Assim sendo, os significados relatados estão muito pautados pela vivência daquela situação de procura específica e daquele momento particular; por certo, relatos colhidos em outros momentos da vida do demandante ou em outras situações de procura deveriam gerar uma narrativa em que outros significados pudessem ganhar proeminência, ou em que esses significados pudessem ser narrados de outra forma. Portanto eles são também "significados situados", ou seja, pautados pela situação social em que foram estimulados e narrados. E esta razão é, ela mesma, heuristicamente valiosa para um trabalho, como este, que pretende penetrar, de perto e de dentro, da situação de procura de trabalho.

Apesar disso, não deixamos de considerar na análise que se segue aqueles significados associados a vivências sociais distintas que a situação de procura pode produzir e que foram apresentados no sub-item anterior. Muitos desses significados dão indícios da importância que a atividade da procura de trabalho pode adquirir dentro da experiência do desemprego e das possíveis causas para a insistência na procura, apesar da descrença na obtenção de trabalho no dia da entrevista (afirmação aparentemente contraditória, mas muito freqüente entre os diversos tipos de demandantes).

Menos do que uma análise profunda e um levantamento exaustivo das representações e significados sociais da procura de trabalho, o que se faz nesse item, que se constitui numa exploração primeira dos achados, é a recuperação do repertório dos significados que foi possível apreender nos discursos, encetando-se primeiras explorações analíticas com respeito aos mesmos.

\section{1 - Legitimação social e manipulação de estigmas}

Chama a atenção em primeiro lugar um achado: a insistência na procura parece expressar uma forma de resposta à pressão social que se exerce sobre o desempregado, obrigado que está à procura de trabalho como maneira de diferenciar-se dos vagabundos, legitimando, dessa forma, a sua situação temporária de não-trabalhador. Tal como discutido no capítulo 1, a categoria “desempregado" está condicionada acadêmica e administrativamente definida por sua umbilical 
associação à procura regular de trabalho; assim são construídos os números e estatísticas sobre o desemprego e assim tem sido formulada a maior parte das análises que sobre esses números se erige. Mas, para além de uma categorização oficial e institucional, aparentemente distante da vida cotidiana das pessoas; ali, a procura de trabalho também é fundamental para legitimar socialmente o desempregado dentro de seu circulo social. De acordo com vários depoimentos, o desempregado que não procura trabalho regularmente é mal visto. É necessário sair de casa para procurar, distribuir o maior número de currículos, coletar o maior número de informações. ${ }^{62}$

É preciso procurar trabalho regularmente e mais, é preciso fazer com que as pessoas do seu meio social saibam; a procura deve ser visível aos olhos dos outros. Isso para evitar a imagem de desocupado, preguiçoso e incapaz. Aquele que procura trabalho regularmente, ao contrário, é visto como temporária ou ocasionalmente fora de atuação, sem sorte ou vítima de uma crise econômica. O estigma da condição de desempregado é amenizado quando entra em cena a imagem proativa de "demandante de trabalho". Nesse caso, quando há procura de trabalho reconhecida, a culpa da condição de desemprego se desloca, em parcela importante, do próprio indivíduo desempregado para as estruturas sociais exteriores a ele, tais como a economia, o mercado de trabalho, a ineficiência dos políticos, etc. A questão do estigma pode ser tão significativa que não raro as pessoas preferem não dizer que estão desempregadas, mas que estão "procurando trabalho". A procura de trabalho traz em si uma dimensão positiva, que é ressaltada, e possibilita esconder ou evitar a palavra "desemprego", tão impregnada de significados negativos. Por isso mesmo, na realização do trabalho de campo optou-se por usar a expressão "procura de trabalho", ao invés da palavra "desemprego", embora sempre prestando atenção às formas como essa última era utilizada ou evitada, por meio de estratégias de contorno. Isso porque, a procura de trabalho tanto é usada como figura de legitimação social da categoria de desempregado, como pode também ser acionada como forma de evitar a auto-classificação nessa categoria. A atividade da procura de trabalho pode ser subjetivamente manobrada de forma a amenizar estigmas sociais, seja de desocupado, seja mesmo de desempregado, e, por isso é tão impregnada de importância social e simbólica.

\footnotetext{
${ }^{62} \mathrm{~A}$ força simbólica com que esse valor se exprime, dá lugar a formas significativas de nomeação; por exemplo expressas na recusa à atribuição (ou à assunção) da condição de desempregado, preterida pela de "batalhador", aquele que "está na luta", ou "está na batalha" - luta e batalha que por vezes significam estar "se virando" no mercado no exercício de "bicos", mas que outras vezes quer aludir ao fato de que se está em busca intensa, dedicada e sistemática de um novo trabalho (Guimarães, 2009-b). Sua vigência é tão impressionantemente forte, e associada a uma significação positiva do trabalho, que foi encontrada em diversos contextos societais, como um dos mínimos denominadores comuns; Assim, Sugita, por exemplo, documentou-a nos discursos dos jovens desempregados da região de Tóquio, para quem ser desempregado é coisa dos antigos, daqueles a quem pode-se atribuir o "ter desistido de procurar trabalho" (Demazière, Guimarães e Sugita, 2006)
} 


\section{2 - "Quem procura acha"}

A expressão "quem procura acha" foi frequentemente repetida por vários entrevistados, assim como expressões semelhantes a ela, em referência à importância da atividade de procura. Essa idéia é muito associada à experiência da procura de trabalho. Esse tipo de máxima é mobilizada para justificar a insistência na procura após frequientes tentativas fracassadas. A idéia subjacente parece ser a de que a obtenção de trabalho só depende do esforço e insistência de cada um e, nesse sentido, que a responsabilidade pela recolocação no mercado de trabalho é totalmente depositada em cada indivíduo e na sua determinação e insistência. Seguindo essa lógica, se um demandante ainda não achou trabalho é porque ainda não procurou o suficiente, e se um demandante parou de procurar é porque não é suficientemente determinado e insistente.

O ditado popular "quem procura acha" reforça a insistência na procura. Esse tipo de representação social tem implícita a idéia de que o trabalho existe, que só depende do indivíduo achá-lo, como num jogo de esconde-esconde. Porém, essa representação social, tão difundida e que mobiliza os atores a procurarem insistentemente, desconsidera que ao demandante não basta procurar, ele precisa ser selecionado, pois no jogo da procura de trabalho não há um único jogador; existe outro, o empregador ou selecionador, e, esse sim, é quem tem controle sobre o jogo.

\section{3 - Sensação de autonomia e controle sobre a própria trajetória}

Além da incorporação de pressões e representações sociais, a procura de trabalho pode ser manejada simbolicamente pelos indivíduos como estratégia de manutenção ou fortalecimento do equilíbrio emocional. Isso, porque a procura de trabalho foi relatada como uma das atividades que podem oferecer a sensação de autonomia e de controle sobre a própria trajetória. O estudo para aumentar a qualificação ou para exames de concursos públicos são outras atividades que dão essa sensação.

Essas atividades minimizam o sentimento de falta de domínio sobre a própria vida e sobre as próprias escolhas e permitem a mobilização das energias e habilidades de cada um em prol do redirecionamento da própria trajetória. Estudos de survey (Guimarães, Hirata, Montagner, Sugita, 2004) mostraram, para demandantes em busca de trabalho na Região Metropolitana de São Paulo, que a razão mais apontada pelos próprios entrevistados como causa de seu insucesso na procura é creditada a suas próprias limitações. Os indivíduos incorporam a culpa do próprio insucesso e a capacitação e o investimento na procura são os antídotos reconhecidos como cabíveis por muitos deles, sendo tratados como suficientes para superar essas dificuldades. Esses antídotos significam um investimento na própria trajetória, e minimizam desconsolo da falta de ocupação. Deposita-se 
no próprio esforço, aplicado no estudo e na procura, a responsabilidade do sucesso da saída da condição do desemprego. Acredita-se que essa é uma das razões pelas qual o interesse pelos concursos públicos vem aumentando à medida que aumenta também o tempo de procura de trabalho entre os desempregados, sem falar, é claro, do sonho da estabilidade da carreira pública.

A tentativa de recuperar o controle sobre a própria vida foi, cremos que por isso mesmo,um dos significados da procura de trabalho mais presentes nas narrativas.

\subsection{Reorganização do tempo e da rotina}

A experiência do desemprego é muito marcada por uma sensação de monotonia e ociosidade e a questão do tempo livre é muito citada como elemento emocionalmente desestabilizador. São elementos constitutivos da experiência do desemprego a falta de atividades regulares, a falta de rotina, a falta de horários e a sensação de inutilidade.

De acordo com os relatos, a procura de trabalho pode ser entendida como um elemento norteador da organização do tempo e do cotidiano do desempregado, pois há uma incorporação dessa atividade à rotina e organização do tempo em função dela. A experiência de procura de trabalho combate a sensação de ociosidade e preenche o tempo livre de uma forma positiva. Há uma certa organização das atividades semanais em função dos dias dedicados à procura, assim como uma organização do dia em função da atividade da procura de trabalho. Quando em procura regular de trabalho, a rotina do demandante ganha movimentos e contornos e é pautada por atividades e objetivos a serem cumpridos. O preenchimento do tempo e a organização da rotina constituem outro significado importante da procura de trabalho.

\subsection{Recuperação da dimensão pública da vida social}

Busca-se também, através da atividade da procura de trabalho, a experiência da vida pública que contrasta com a natureza privada da rotina domiciliar do desemprego. Sair para procurar trabalho cria a sensação de autonomia na construção do próprio destino, mas também ameniza a tão citada "angústia" de ficar dentro de casa "sem ter o que fazer". Almeja-se sair de casa, ver outras paisagens, mas também a interação com outras pessoas, a troca de experiências, o estabelecimento de novos contatos, os quais podem até resultar em futuros canais de informação sobre oportunidades de trabalho. A recuperação da dimensão pública da vida social foi citada como uma característica importante e interessante da atividade de procura de trabalho. E isso pode ser especialmente importante aos demandantes que acorrem às agências do Centro da cidade, onde há muita interação, muitos estímulos e a vida social é muito rica e intensa. Todo esse contexto de 
interações e efervescência pode produzir sensações de animação e euforia, que contrastam com a monotonia do insulamento domiciliar, típico do desemprego.

\subsection{Renovação da esperança e das expectativas}

A manutenção da esperança é outra forma sobre a qual a procura de trabalho incide positivamente no equilíbrio emocional de desempregados. E, como se acredita que "quem procura acha”, a esperança se mantém e sempre há a expectativa do contato de alguma agência de emprego na qual se deixou o currículo. Assim, a procura gera expectativas ao mesmo tempo em que as renova. E nisso reside um dos importantes significados simbólicos dessa atividade, já que uma longa experiência de desemprego pode levar ao desconsolo, ao desespero e à depressão.

Com esperança e expectativas renovadas, há mais probabilidade de continuidade da procura, da busca de novas estratégias de procura, de investimento em qualificação ou mesmo de vislumbrar possibilidades alternativas de ocupação e geração de renda, evitando, por exemplo, a depressão e/ ou a entrada na inatividade. A manutenção da esperança é muito importante para o equilíbrio emocional do demandante, inclusive para manter a procura, o que caracteriza o último significado social da procura de trabalho aqui listado.

\section{A situação de procura e a experiência social da procura de trabalho: considerações finais}

A experiência social da procura de trabalho é constituída de um repertório de situações sociais e fruto de uma articulação complexa e imprecisa de vivências sociais dos demandantes. A vivência da situação de procura de trabalho analisada pode ser constituinte dessa experiência, por isso foi tomada como recorte empírico e como local de observação e coleta de discursos.

A atuação na situação de procura está pautada em regras e códigos próprios da dinâmica daquela situação social específica, como problematizado no capítulo anterior. Mas, da mesma forma como a própria situação de procura está articulada a outras situações sociais e outros fenômenos sociais, como também apresentamos no capítulo 3, a experiência social da procura não se encerra no momento de busca e se articula a outras vivências, a outras dimensões e a outros fenômenos da vida dos demandantes, além da experiência construída na própria situação de procura. Dessa articulação complexa e imprecisa de elementos foram eleitos três, a partir dos quais se buscou, neste capítulo, entender a experiência social da procura de trabalho, mesmo se numa abordagem ainda exploratória. 
O primeiro passo para compreender melhor essa experiência, tal como vivida pelos demandantes foi olhar para o contexto social em que eles se encontravam, atentando para algumas características sociais. Para entender de que lugar social aqueles atores olhavam, analisavam e interpretavam aquela situação de procura era preciso entender melhor a própria vida desses demandantes e o contexto social no qual estavam inseridos. Isso permitiu a percepção das dificuldades, das expectativas e dos constrangimentos que delineavam experiências de procura diversas e, conseqüentemente, formas distintas de viver aquela situação social estudada. Foi possível identificar quatro tipos de experiências de procura de trabalho, as quais estavam baseadas em quatro conjuntos de características sociais de demandantes.

$\mathrm{Na}$ compreensão da experiência social de procura destacou-se, em segundo lugar, o papel analítico da articulação dessa experiência com outras esferas e experiências da vida social do demandante de trabalho. Essas articulações que podem ser vistas, retomando a metáfora de Goffman, como as membranas de contato dessa experiência com outras dimensões sociais, são buscadas nas análises micro-sociológicas com a intenção de mostrar que a vivência cotidiana das situações sociais, as mais corriqueiras, está sempre impregnada das estruturas sociais que as comportam, assim como dos significados sociais que lhes dão sentido.

Do ponto de vista da articulação com outras vivências sociais de natureza micro, a experiência da procura de trabalho é pautada por um conjunto de comportamentos, discursos e códigos que são aprendidos, transmitidos, discutidos, trocados e interpretados em situações sociais diversas como no seio da família, da rede de amigos e de meios de comunicação, sem falar, claro, da vivência da própria atividade de procura de trabalho. A vivência de situações sociais aparentemente desconectadas com a situação de procura pode oferecer elementos e informações que serão nela mobilizadas. Além disso, a vivência da situação de procura pode engendrar outras vivências sociais como a experiência urbana, a experiência de lazer e a experiência de consumo, que passam a criar novos significados para a experiência da procura de trabalho.

Já no que se refere à articulação dessa experiência com dimensões sociais de natureza macro, é importante ressaltar, em primeiro lugar, que mesmo a conduta social do demandante de trabalho, construída de forma múltipla em diversas situações sociais, inclusive a situação de procura, também passa pelo mercado de intermediação e pelo mercado de trabalho através dos valores e exigências eleitos como legítimos pelo universo da gestão de recursos humanos. Outro apontamento com relação à articulação dessa experiência com fenômenos de nível macro pôde, então, ser feito. A ausência de instituições governamentais eficazes de suporte ao desemprego e à procura de trabalho 
também influencia sobremaneira na natureza dessa experiência, acentuando sua dimensão individual em detrimento da dimensão social. Devido a essa característica institucional, a recolocação no mercado de trabalho é uma responsabilidade do indivíduo que, fazendo uso de suas próprias habilidades, meios de informação e redes sociais, tem que arcar com os custos materiais e simbólicos desse empreendimento. Por isso, o período de procura de trabalho está frequentemente associado à privação material e ao desenvolvimento de trabalhos ocasionais, os "bicos". Ademais, essa lacuna institucional estimula o recurso aos meios privados de intermediação de mão-de-obra, como as agências que operam na situação estudada, e às redes sociais como suporte material. Na ausência de apoio institucional e das redes sociais, os indivíduos se vêem obrigados a realizar uma "busca com urgência”, ou seja, uma busca pouco pautada por critérios de seletividade, onde o que dá o tom é a premência material, característica marcante da experiência de parcela considerável dos demandantes entrevistados naquela situação de procura.

Olhando para a dimensão subjetiva, o terceiro elemento constitutivo da experiência estudada, foi possível avançar que, uma mesma experiência subjetiva pode ser, e frequentemente é, marcada por dois conjuntos antagônicos de significados sociais e de sentimentos individuais. Os discursos dos demandantes de trabalho parecem sugerir que esses sentimentos são constituintes da mesma experiência social, e são, só aparentemente, expressões subjetivas contraditórias. Por isso, proponho que o podemos entender recorrendo à metáfora de uma moeda e seus dois lados.

Por um lado, a dor, a angústia, a insegurança, o medo e ansiedade gerados pelo processo de aprendizagem e incorporação de códigos de conduta pouco triviais, ditados por universos sociais muitas vezes distantes da maioria das pessoas e pelo processo constante de julgamento do bom desempenho dessa conduta. Todo esse processo, que começa pela aprendizagem dos códigos sociais e termina na avaliação do personagem encenado na situação de procura, é constituído pela manipulação de símbolos e significados e permeado de sentimentos. A incompreensão dos códigos, o medo do julgamento alheio, a dor de uma candidatura negada ou da eliminação de um processo seletivo fazem parte da experiência da procura. Cada "não" recebido ao longo desse processo corresponde a sentimentos de frustração e humilhação. Aqui desse lado da moeda, a situação de procura cria sentimentos que podem ser negativos, configurando a experiência da procura de trabalho com uma experiência difícil que potencializaria as dores típicas da experiência subjetiva do desemprego.

Do outro lado da moeda, a vivência da situação de procura também engendra sentimentos positivos como a esperança, a expectativa renovada, a sensação de controle sobre a própria vida, o 
preenchimento do tempo livre, a reorganização do cotidiano, a empolgação e a euforia. Esses sentimentos, constituintes da experiência de procura, permitem encarar a experiência do desemprego com mais facilidade, assim como permitem a manutenção da esperança, tão importante no próprio processo de procura. E, ainda, a vivência da procura permite a manipulação da identidade social pelos indivíduos, legitimando sua identidade de desempregado ou escondendo essa categoria para a incorporação da identidade de demandante de trabalho. Além da obtenção de um posto, a atividade de procura pode contribuir positivamente para a vivência do desemprego do ponto de vista subjetivo.

Com isso tentamos mostrar como é ambivalente, em sua rica complexidade, a vivência da situação de procura estudada. Ela faz parte da experiência da procura de trabalho, a qual está pautada no contexto social do demandante, nas vivências e experiências dele e está impregnada de sentimentos e significados que incidem sobre as ações dos demandantes, dentro e fora das situações de procura. Além da riqueza de elementos analíticos e questões sociológicas que essa experiência social revelou, tentamos mostrar, por último, a importância que ela adquire na vida dos demandantes, ressaltando mais uma vez a pertinência de estudá-la. 


\section{CONSIDERAÇÕES FINAIS}

\section{A experiência da procura de trabalho a partir de um estudo de caso}

A procura é uma das variáveis definidoras da categoria de desempregado, mas é possível também que esteja dissociada do desemprego já que nada impede que ela venha a ser realizada durante períodos de ocupação. À medida que a procura pode estar descolada da condição de desemprego, é razoável trata-la analiticamente como uma atividade em si e como um dos processos constitutivos das trajetórias dos trabalhadores, sejam eles desempregados ou não.

Porém, mais que isso, o que se buscou mostrar ao longo deste trabalho foi que a procura configura uma experiência social em si mesma. Uma experiência na qual são engendrados processos sociais peculiares e que configura um universo simbólico próprio. Ainda que o objetivo da procura de trabalho seja a obtenção de uma nova ocupação ou a re-inserção no mercado de trabalho, a vivência da procura está pautada por códigos, práticas, condutas e significados que provêm da esfera do trabalho, mas ela é igualmente tributária de outros códigos, práticas, condutas e significados que não necessariamente se desenvolvem nesta esfera, mesmo que possam revelar muito sobre ela. Esses elementos sociais que regem a prática cotidiana da procura ajudam a compreender o processo de convergência entre uma vaga de trabalho e um candidato, ou seja, o resultado final do encontro entre ofertantes e demandantes de emprego, que é o processo mais fundamental do mercado de trabalho.

O processo de procura de trabalho, no entanto, foi apenas marginalmente tratado pela Sociologia do Desemprego e praticamente ignorado pela Sociologia do Trabalho. Essa última tem enfrentado a procura apenas como uma variável de construção das medidas do desemprego. Já a primeira se dedicou a estudar o movimento que leva da ocupação ao desemprego, mas só muito raramente concentrou a sua atenção no movimento que leva à saída dele e à re-inserção no mercado de trabalho. Assim, essa abordagem sociológica do desemprego, que de forma tão pertinente analisou esse fenômeno como uma experiência subjetiva e moral e buscou desvendar a "dimensão do vivido" no que diz respeito a ela, apenas tangencialmente tratou da procura. E, quando o fez, não buscou compreende-la como uma vivência social, moral e subjetiva.

Identificadas essas lacunas e as potencialidades da análise da procura de trabalho - nela retendo o distintivo de ser uma experiência social, moral e subjetiva, tornou-se então o objeto de interesse dessa pesquisa, que buscou avançar nesta direção. 
Foi possível identificar alguns dos fatores que fazem da procura de trabalho não só uma experiência econômica, mas também social, moral e subjetiva, nos termos da sociologia do Desemprego. Estudando a procura tal como ela é vivida numa situação específica foi possível tornar visíveis e compreender melhor os processos micro-sociológicos que constituem essa experiência, assim como desvelar ao menos alguns dos constrangimentos, significados e sentimentos que a compõem, enquanto fenômeno que contempla uma dimensão do vivido que lhe é essencial. Portanto, aqui nas considerações finais busca-se destacar esses dois eixos de achados e questões que o estudo de caso permitiu apontar sobre a experiência da procura: os processos micro-sociológicos e a dimensão do vivido.

Sabe - se, desde os trabalhos seminais de Granovetter $(1973,1974)$ que é com muita dificuldade que circulam as informações sobre oportunidades ocupacionais e que as redes sociais seriam fundamentais no processo de convergência entre uma vaga disponível e um candidato, funcionando como verdadeiros atalhos informacionais. A procura seria, portanto, um processo intrinsecamente social. Entretanto, no modo de construir o objeto deste estudo, assume-se que a natureza social desse processo pode se manifestar através de outras formas, além daquela que ficou consagrada nos estudos de Granovetter, ou seja, além das redes sociais.

Para tal, tomamos um caso em que as ofertas de trabalho circulam através do mercado, um mercado de intermediação, fortemente institucionalizado; ou seja, em tese, as redes pessoais não seriam ali os mecanismos precípuos para tal circulação. Nem por isso a construção social da procura era menos evidente, e a complexidade do processo menos palpável. Assim, foi possível constatar ali que o processo de procura, conquanto manifeste, na situação estudada, uma aparência mercantil e empresarial que salta aos olhos logo à primeira observação, está completamente enraizado nas relações sociais, algumas vezes através das redes, tal como antecipara Granovetter, mas, e principalmente, através dos fundamentos sociais e simbólicos que ancoram as interações entre os agentes econômicos. O processo de procura no caso estudado é construído a partir de uma dinâmica de interações, para cuja compreensão é imprescindível ter em conta processos de natureza micro-sociológica. Ademais, a vivência dessa atividade está pautada em constrangimentos sociais e pressões morais e baseada em sentimentos e significados sociais, os quais se pretende retomar brevemente aqui.

Com a análise da constituição de uma situação de procura buscou-se compreender o próprio processo de procura e os elementos micro-sociológicos dessa vivência enquanto ela é realizada num determinado local da cidade, através de um conjunto específico de instituições e a partir das 
interações entre certos atores. Retomar essa preliminar é importante posto que o processo de procura, quando transcorre em outros contextos ou através de outras estratégias, deve se realizar através de outras dinâmicas micro-sociológicas. A escolha desse contexto de procura, e não qualquer outro (como a procura virtual, ou a procura por anúncios de jornais, ou a procura direta junto a firmas, só para referir alguns deles) se justifica pelo crescimento da relevância das instituições de intermediação no mercado de trabalho e por aquele ter se mostrado o principal espaço de procura da metrópole paulista e, portanto, um grande concentrador de informações ocupacionais.

Uma das especificidades da situação de procura escolhida, é que este espaço concentra principalmente informações sobre vagas de trabalho de má qualidade e atrai especialmente demandantes jovens e pobres, os quais, diante da escassez de informações ocupacionais, se lançam numa procura pouco seletiva e urgente. Produzimos e apresentamos ao longo deste trabalho, uma análise sobre a procura que é, ela mesma (não apenas a procura, mas a nossa própria análise) contextualizada, pois tem que levar em conta as características das instituições e dos atores que caracterizam a situação escolhida.

\section{A procura de trabalho e os processos micro-sociológicos}

O estudo qualitativo, de base etnográfica, sobre uma situação de procura revelou o quão complexo, do ponto de vista micro-sociológico, pode ser o processo de busca de trabalho. Analisando a dinâmica da situação e a atuação dos atores foi possível apreender alguns dos processos micro-sociológicos que engendram a procura e que estão na base da convergência entre uma vaga de trabalho disponível no mercado e um candidato que a ela se apresenta. Aqui ressaltamos, à guisa de conclusão, alguns desses aspectos, principalmente aqueles com maior potencial para alterar o curso desse processo de convergência.

A abordagem micro-sociológica do caso estudado permite apontar primeiro, que os demandantes de trabalho têm que desenvolver uma performance própria, a qual é composta por certas práticas e códigos. Essa forma de atuação típica se dá através de ações, gestos e discursos e constitui a "conduta do demandante do trabalho". Ela será julgada e avaliada no processo de procura tanto pelos funcionários das agências, sejam eles as recepcionistas, os selecionadores ou até os plaqueiros, quanto pelos seus concorrentes, ou seja, os outros demandantes. Assim, essa performance é constituída em interação com os outros atores da situação e dentro de uma dinâmica de interações relativamente articuladas e organizadas, onde demandantes e funcionários do mercado 
de intermediação sabem (e, simultaneamente, aprendem) qual papel devem desempenhar. A procura de trabalho é, nesse sentido, um processo interativo.

$\mathrm{Na}$ análise das situações sociais, e seguindo a pista do interacionismo simbólico, ressalta-se a importância dos atores e seu poder de agência, manipulação, negociação e re-interpretação do léxico social, articulando-se a isso a força de condicionantes sociais e culturais que engendram comportamentos institucionalizados ou generalizados. Essa articulação, que pode ser imprecisa, se expressa na vida mais cotidiana dos indivíduos organizando-a, pois a vida social composta por diferentes situações sociais não é um caos, mas um quebra-cabeça ditado por uma ordem social que em Goffman é anunciada como sendo uma "ordem interativa" e em Strauss é referida como uma “ordem negociada". Esse tipo de ordem social é construído também pelos atores, e nisso reside a especificidade de tal abordagem teórica, que é aqui tomada de empréstimo e que permite entender aquela situação de procura, recuperando-a enquanto uma dinâmica organizada de interações entre demandantes e funcionários do mercado de intermediação ou de serviços correlatos à procura.

O processo de convergência entre vagas de trabalho ofertadas e candidatos é, do ponto de vista da micro-sociologia, composto por uma série de interações e cada uma delas é delineada por regras implícitas e por técnicas interativas diferentes. Dentro desse processo, o objetivo do demandante é a obtenção de um trabalho (o melhor trabalho possível do seu ponto de vista) e o preenchimento de uma dessas vagas que estão em jogo no mercado. Para tanto, ele tem um longo percurso interativo a fazer e, nele, lhe cabe construir uma performance convincente.

No caso do demandante, a manipulação das informações que constroem sua imagem, ou seja, sua conduta, é especialmente importante, pois determina sua relação com os outros atores, mas pode também determinar seu sucesso ou fracasso na obtenção de trabalho, retomando o argumento de Goffman. Porém, essa conduta, ao mesmo tempo em que é constituída de um conjunto de códigos, é também flexível e permite negociações e re-interpretações por parte dos atores sociais, assim como a manipulação de informações, no qual se esconde aquelas que podem ser negativas e ressalta as que podem ser positivas. Da necessidade de desempenhar um conjunto esperado de práticas e da possibilidade de re-interpretá-las advém toda a preocupação do demandante com o vestuário, com a aparência, com a confecção do currículo e o desejo de entender, de fato, o que é que se espera de um bom candidato, para, a partir do entendimento dessa expectativa social, poder dominar esses códigos e bem representar seu personagem - ou a atitude social generalizada, nos termos de Mead, ou as condutas socialmente institucionalizadas, nos termos de Goffman. Para manipular positivamente suas informações, o demandante de trabalho tem que saber qual é a 
performance esperada do "bom candidato", o que eles nem sempre sabem e por isso encontram dificuldades no seu processo de busca, como desenvolvemos nos capítulos 3 e 4.

Mas, além de um processo interativo, a procura de trabalho é um processo de julgamento e avaliação. A interação entre demandantes e funcionários das agências é completamente pautada pelo julgamento dos primeiros pelos segundos, o que configura uma interação regida pela diferença e desequilíbrio dos papéis sociais. Esse julgamento se dá a partir de critérios que os selecionadores elegem como legítimos e que, como demonstramos, os demandantes podem desconhecer. Alguns desses critérios que direcionam a expectativa que o mercado de intermediação tem em relação aos demandantes são independentes dos pré-requisitos específicos a cada tipo de vaga: boa apresentação de si (tanto através do currículo quanto da aparência física), boa capacidade de expressão oral, domínio da língua, capacidade de elaborar opiniões e construir argumentações, além de juízos fortemente subjetivos e de difícil aferição comparativa numa situação de concorrência como "força de vontade", "vontade de vencer", "garra”, "determinação", "pró-atividade”, "comprometimento", "responsabilidade", "segurança", "confiança", "iniciativa", "liderança".

Mas, quando não há partilha das regras e dos códigos que formam a base do léxico social de uma dinâmica de interação e dos critérios de julgamento, podem haver conflitos ou frustração de expectativas. No caso da procura de trabalho, quando o demandante não sabe o que os representantes do mercado de intermediação esperam dele ou quando não consegue encenar adequadamente essa conduta o que se frustra é a expectativa de obtenção de trabalho. Para o sucesso na procura não basta ao demandante preencher os pré-requisitos do mercado de trabalho como qualificação e experiência profissional, é preciso ter acesso às informações ocupacionais, que são escassas, há que dominar o conjunto de códigos e as práticas da procura, que é complexo e subjetivo, e é imperioso cumprir as expectativas dos outros atores econômicos em relação a ele.

Essa incompreensão das expectativas ou a falta de domínio dos códigos da conduta do demandante é apontada pelos selecionadores como o principal problema dos processos de seleção e recrutamento; mais ainda, eles sugerem que essa é uma característica do perfil dos demandantes que acorrem àquele espaço de procura, geralmente jovens e provenientes de classes pobres, ainda que possam ter escolaridade média ou até superior. Como foi possível identificar nos relatos há realmente muitas incompreensões, por parte desses demandantes, a respeito do que se espera deles na busca, e como isso pode ser fator de insucesso nessa empreitada, gera-se ansiedade, insegurança e medo, sentimentos frequentemente associados à vivência dessa atividade. 
Porém, outro dos achados da pesquisa é que, diante de tais incompreensões e falta de domínio dos códigos, pode haver, e muitas vezes há, uma busca ativa de informações a esse respeito. Motivados por interesse e curiosidade, os demandantes fazem desse um assunto privilegiado nas esferas da família e, principalmente das amizades, e podem investir em uma pesquisa sobre esse tema em internet, pesquisas e livros. Busca-se "aprender" aquilo não foi socialmente incorporado. Isso porque a conduta do demandante de trabalho não é, como outros papéis sociais podem ser, socialmente incorporada ao longo da trajetória dos indivíduos. Como ressaltamos, não é na esfera do trabalho nem nas instituições de ensino que esses códigos são formalmente transmitidos. Esse conjunto de regras e práticas é apreendido em múltiplas dimensões da vida social do demandante, como família, amigos e meios de comunicação, mas também pode ser incorporado, a partir de observações, no próprio processo de procura e, como acontece na situação investigada, virar alvo de serviços mercantis, como a elaboração de currículo, por exemplo. Portanto, pode-se apontar que as condutas sociais são situadas e construídas no curso das interações, mas também são articuladas às outras situações sociais e a outras dimensões sociais da vida dos demandantes. E o bom desempenho dessa conduta é fundamental no processo econômico de concorrência pelas vagas disponíveis no mercado de trabalho.

Além das interações com selecionadores e recepcionistas, há uma outra interação, típica daquela situação de procura, e que se revelou capaz de interferir no curso do processo de procura, com potencialidade para, inclusive, determinar seu resultado final. Trata-se da interação entre plaqueiros e demandantes. Na rua, os demandantes podem, durante o processo de interação, fazer negociações com os plaqueiros persuadindo-os a recolher um currículo que, a princípio, não preencheria todos os requisitos da vaga. Nesse processo simples, um demandante que estaria fora da concorrência por uma vaga, insere seu currículo nessa competição a partir de uma negociação com o plaqueiro, e passa ater chances de ser selecionado. A situação de procura de trabalho, tomada como unidade analítica, também pode configurar um contexto de negociação no qual vagas de trabalho e adequação de demandantes a essas vagas são negociadas, entre outros elementos. Mas, a interação do demandante com o plaqueiro pode interferir no processo de procura ainda por outra via.

Como mostramos no capítulo 3, esses personagens não só divulgam vagas e recebem currículos, mas também podem ser agentes ativos de captação de demandantes através de sua rede pessoal de contatos e de sua clientela. Assim, se um demandante que freqüenta aquele cluster de intermediação criar uma relação diferenciada com um ou outro plaqueiro pode passar a ser parte da clientela deste, ou seja, ter acesso privilegiado ao conjunto de contatos que ele pode acionar para o 
preenchimento de certas vagas. Através dessa relação diferenciada, um demandante pode ter acesso privilegiado a informações sobre postos de trabalho, o que é fundamental dada a grande dificuldade com que circulam tais informações. A partir da análise das relações entre demandantes e funcionários das agências (recepcionistas, selecionadores e plaqueiros), é possível afirmar que as diversas interações sociais, pela forma como transcorrem, ou seja pelo modo como são socialmente negociadas nos micro-contatos, podem igualmente determinar o curso do processo de convergência entre uma vaga e um candidato, mesmo quando tal processo se dá no bojo de instituições de intermediação.

No que diz respeito à natureza das relações entre os próprios demandantes de trabalho no seio do processo de procura, elas podem ser tanto de cooperação e cumplicidade quanto de competição e concorrência. No primeiro caso, pode haver troca de experiências e informações sobre oportunidades ocupacionais e esse tipo de interação pode vir a produzir, inclusive, o conhecimento de alguma possibilidade de obtenção de trabalho que eventualmente se concretize. Esse tipo de interação se dá principalmente na rua e no momento da distribuição de currículos, quando, a princípio, os demandantes não competem pelas mesmas vagas. Porém, durante um processo seletivo a interação entre candidatos à mesma vaga é pautada pela concorrência e pela necessidade de que um candidato se sobressaia frente aos demais. Nesse caso, quanto menos informações um candidato partilhar com seu concorrente, melhor, pois o que rege essa interação é a competição econômica. Nas interações entre candidatos nas dinâmicas de grupo, por exemplo, é fundamental que eles demonstrem suas qualidades, evidenciando as fragilidades dos concorrentes. Ou seja, as interações entre os próprios demandantes, cúmplices da mesma condição ou concorrentes econômicos, podem contribuir para o resultado final do processo de procura, positiva ou negativamente.

Quanto aos processos micro-sociológicos que dão base à vivência do processo de procura de trabalho é importante ressaltar o papel do espaço como variável que influencia na dinâmica das interações e que dá novas dimensões e significados à experiência da procura. A atividade da procura de trabalho pode ser, e muitas vezes é, espacialmente pautada. Isso não quer dizer simplesmente que a procura de trabalho se realiza num determinado espaço, mas que, na situação investigada, ela é diretamente influenciada pelo espaço em que se realiza. O território de procura de trabalho é, portanto, o que dá a base espacial para a encenação da situação de procura, determinando a sua dinâmica micro-sociológica de interações. Esse território é configurado pelos usos sociais do espaço pelos diversos atores que nele atuam. Ademais, ele é fluído, não é fixo e concretamente delimitado, 
abrigando e criando as condições de possibilidade para um conjunto de práticas e condutas razoavelmente articuladas e organizadas em torno da atividade da procura de trabalho.

Porém, o espaço é especialmente importante na experiência da procura de trabalho por mais algumas razões. Primeiro, pois se constituindo numa atividade, e não num estado, tal como o desemprego, a procura de trabalho é circunscrita num tempo e num espaço. E o espaço é, ainda mais importante à medida que se sabe que o mercado de intermediação de mão de obra é uma construção territorializada (Guimarães, 2007-c, 2007-d). Então, a procura de trabalho em agências de emprego na metrópole paulista é uma atividade circunscrita em determinados espaços do tecido urbano. Além disso, o próprio trabalho de campo pode comprovar que a procura de trabalho no Centro da cidade é, não só uma experiência de natureza econômica, mas é também uma experiência urbana, uma experiência de deslocamento e de localização simbólica na cidade.

Esses processos micro-sociológicos de interações e construção de condutas sociais regem a dinâmica da procura e, como apontamos, são determinantes dela e do resultado final da busca. Isso reforça a idéia de que o processo de convergência entre uma vaga e um trabalhador é também um processo de natureza micro-sociológica. A procura de trabalho é uma atividade que se desenvolve no bojo da esfera da economia, mas, como todo processo econômico, é permeado por relações e constrangimentos sociais. Isso também é verdadeiro para a procura de trabalho através das instituições de intermediação, como acreditamos haver demonstrado. Para que, ao final, haja convergência entre um posto de trabalho e um candidato é necessário que os atores econômicos passem por um longo caminho de interações, negociações, manipulação de informações, partilha de expectativas e julgamentos, como a análise permitiu desvelar. A observação da prática da procura permitiu identificar que nessa dinâmica cada ator econômico tem uma função e um conjunto de práticas a ela relacionadas. Ainda mais, é possível reiterar que a operacionalização prática dessa convergência se dá através de inúmeros processos micro-sociológicos e deles depende, inclusive, o seu resultado final.

O processo econômico de procura de trabalho em instituições de intermediação é, se abordado por uma lente micro-sociológica, também um processo interativo, um processo de construção de condutas, um processo de julgamento, um processo de concorrência, um processo de negociação, um processo de aprendizagem de códigos, um processo de troca de informações ocupacionais e um processo de deslocamento e localização simbólica na cidade.

A vivência desse complexo processo micro-sociológico, por parte dos demandantes, é orientada por objetivos econômicos, mas também é pautada por constrangimentos sociais e por sentimentos e 
significados próprios, como a análise dos discursos revelou. Esses elementos constituem a dimensão social, moral, e subjetiva da experiência da procura, a "dimensão do vivido", e se expressam tanto durante o próprio processo econômico de procura, como em outras dimensões da vida dos demandantes de trabalho.

\section{A vivência da procura de trabalho: elementos sociais, morais e subjetivos}

Através desse estudo de caso foi possível avançar no entendimento da vivência da procura de trabalho, não apenas através de seus processos micro-sociológicos situados, mas também de sua dimensão social, moral e subjetiva. Com base nos discursos dos demandantes, colhidos numa situação de procura específica, foi possível entender um pouco mais sobre como essa vivência é condicionada por elementos sociais exteriores à situação e como essa atividade é simbólica e subjetivamente incorporada à vida dos demandantes e interpretada por eles.

A vivência do processo de procura é condicionada, em parte, pelo contexto social dos demandantes. Para entender como os demandantes vivem e interpretam o processo de procura é necessário entender de que lugar social eles vem, pois diferentes contextos sociais produzem dificuldades, expectativas e constrangimentos também diversos e esses se expressam sob formas diferenciadas de viver a procura. Foi possível identificar quatro tipos de experiências de procura pautadas pelas diferentes características dos demandantes: a) Busca do primeiro emprego, b) Jovens adultos em busca de um bom emprego, c) Jovens adultos em busca de um emprego com urgência e d) Adultos em busca de um novo emprego.

Esses tipos foram construídos a partir de características sociais (idade, posição na família, condição social, escolaridade, trajetória de trabalho anterior e tipo de trabalho procurado) e subjetivas (expectativas, objetivos, dificuldades e sentimentos) dos demandantes. A partir desse exercício de tipificar as experiências de procura foi possível dizer, por exemplo, que quanto mais elevada a idade, maior a pressão social para a recolocação no mercado de trabalho. Isso porque a cada momento no ciclo de vida estão associadas certas responsabilidades e representações sociais; assim, se é socialmente permitido a um jovem estudante estar sem trabalho, o mesmo não é verdadeiro para adultos ou para jovens que já concluíram o ensino médio.

A posição do indivíduo na família também é um fator que diferencia a vivência da procura entre os demandantes, pois quanto maior a responsabilidade de um indivíduo no seio familiar, maior a pressão para obtenção de emprego. E, o que se mostrou mais importante para os demandantes que 
circulam no espaço de procura investigado, quanto maior a necessidade material do demandante, mais urgente e pouco direcionada e seletiva a busca de trabalho. Essa necessidade material, que representa um constrangimento no processo de procura, é delineada por algumas características dos demandantes como: condição sócio-econômica desfavorecida, condição de provedor da família ou significante importância na renda familiar, presença de dívidas, tempo elevado de desemprego e ausência de redes sociais de apoio.

Quando a busca é pautada por uma pressão social e familiar ou pela premência material, as expectativas de um bom trabalho diminuem e essa experiência se torna mais dolorosa e pautada pela urgência, pela pouca seletividade e pelos sentimentos de humilhação e de falta de autonomia sob a própria trajetória. Porém, quando a importância do demandante no provimento familiar é baixo ou insignificante ou quando ele é emocional e materialmente apoiado por sua família ou outras redes sociais, a procura de trabalho é uma experiência menos dolorosa, mais seletiva, direcionada e pode trazer em si a possibilidade de um bom trabalho ou de um trabalho melhor que o que se tinha antes. Ou seja, quanto menos constrangimentos sociais atuando sobre o demandante, maior a chance de que a experiência de procura seja vivenciada com otimismo e como uma fonte de oportunidades. Isso se acentua se o demandante tiver razoável qualificação ou uma boa experiência profissional. As pressões e constrangimentos sociais e econômicos se expressam na vivência da procura condicionando as expectativas e dificuldades e os sentimentos relacionados a essa atividade.

A vivência da procura de trabalho também pode se articular à realização de outras atividades, 0 que passa a lhe conferir outros significados. Como já ressaltamos, a procura no Centro da cidade pode configurar não só uma experiência econômica, mas uma experiência urbana, de deslocamento e localização nos espaços da cidade. Assim, a procura de trabalho pode ser também descrita como um retrato da convergência de dois tipos de experiências sociais analiticamente distintas. Por um lado, a "experiência da cidade" expressa na movimentação e atuação no espaço urbano e na vivência da paisagem urbana. Por outro lado, a "experiência da economia" expressa na vivência do mercado de trabalho por intermédio do mercado de intermediação de oportunidades ocupacionais. Mas, como pudemos apreender, a procura de trabalho no Centro pode engendrar também experiências de lazer e consumo e estimular a vivência da dimensão pública da vida social. Isso não é nada desprezível se considerarmos que grande parte dos demandantes é constituída por desempregados que enfrentam a sensação de ócio e inutilidade e o insulamento na vida privada, elementos subjetivos típicos da condição do desemprego. À medida que a procura de trabalho se articula a outras experiências 
sociais, essa vivência ganha novos significados e faz com que essa atividade seja especialmente importante, do ponto de vista simbólico e subjetivo, para os demandantes desempregados.

Para avançar nessa questão é importante ressaltar que cada experiência social engendra um conjunto de significados e que estes pautam a construção subjetiva e simbólica dos fenômenos sociais. Esses significados são coletivamente partilhados, mas podem ser individualmente reelaborados. A vivência da procura de trabalho está envolta por uma série de significados e sensações que constituem sua dimensão simbólica e subjetiva. A análise exploratória dos discursos permitiu apontar a multiplicidade de idéias e representações que estão por trás da vivência da procura e é possível dizer que, como todos os demandantes de trabalho entrevistados eram também desempregados, os significados da procura estão muito articulados à vivência subjetiva do desemprego.

A atividade da procura de trabalho pode ser desempenhada como forma de legitimação social do desempregado dentro do seu círculo social, na tentativa de se diferenciar do vagabundo e evitar esse estigma social, pois aquele que não procura não é bem visto. Ou, o que é mais interessante, essa atividade pode ser mobilizada como forma de evitar o próprio estigma de desempregado. Assumindo a procura ao invés do desemprego, os demandantes ressaltam a dimensão positiva que a procura tem e evitam a palavra "desemprego", impregnada de significados sociais negativos. Nesse sentido, a atividade da busca de trabalho assume dois significados sociais muito importantes, o da legitimação social da categoria de desempregado ou da manipulação do estigma social da mesma.

Dentro da situação de desemprego a atividade de procura assume outro significado simbólico e subjetivo que se mostrou extremamente importante para os demandantes que é a tentativa da recuperação da autonomia e do controle sobre a própria trajetória. À medida que a condição do desemprego, que se caracteriza pela ausência involuntária de ocupação, cria a sensação de falta de controle sobre o próprio destino, a atividade é mobilizada como estratégia de recuperá-lo. Os demandantes investem na procura e assim sentem que estão canalizando suas forças e energias em prol do redirecionamento da sua trajetória profissional.

A procura de trabalho é mobilizada, também, como elemento de reorganização do tempo e do cotidiano dos demandantes desempregados. O preenchimento do tempo e a organização da rotina ajudam a combater a sensação de ócio, típica da vivencia subjetiva da falta de trabalho. Já o insulamento domiciliar, outra característica do desemprego, também pode ser simbolicamente amenizado através da procura freqüente de trabalho. Ao sair de casa para procurar trabalho o demandante recupera a dimensão pública da vida social. No caso da procura no Centro da cidade 
isso é especialmente verdadeiro, pois lá o contexto de interações intensas e efervescência contrastam com a rotina domiciliar da vivência do desemprego.

A cada investimento na procura de trabalho, surgem novas expectativas e esperanças. Por fim, podemos dizer que, como se acredita que "quem procura acha", ao investir na procura o demandante renova suas expectativas e esperanças e pode enfrentar o desemprego com mais confiança e otimismo.

Assim, à medida que o desemprego é carregado de significados sociais negativos, a procura, mesmo que permeada de sentimentos como insegurança, frustração e medo, é interpretada pelos demandantes, principalmente, através de significados sociais positivos. Os demandantes elaboram subjetivamente tais significados positivos da procura de forma a facilitar a dura vivência do desemprego; a procura de trabalho adquire muita importância simbólica e subjetiva na vida dos demandantes desempregados. A identificação dos significados sociais que regem a experiência da procura nos permite dizer que esse é uma vivência social na qual pode haver legitimação e manipulação de identidade social, renovação das expectativas, sensação de controle sobre a própria vida, preenchimento do tempo livre, reorganização do cotidiano e recuperação da dimensão pública da vida.

Nesse sentido, os demandantes, ainda que sejam agentes econômicos, estão sujeitos a constrangimentos sociais e a pressões morais e tais elementos incidem sobre a vivência da procura. E ademais a procura de trabalho, que é um processo econômico, é também pautada por significados sociais e subjetividades.

Acredita-se que foi possível, através deste estudo de caso, avançar no entendimento da procura de trabalho como uma experiência social, moral e subjetiva, além de progredir na compreensão dos processos micro-sociológicos que constituem a vivência desse processo.

Porém, sabe-se que mesmo que tenha sido possível, nesse estudo de caso, compreender melhor os processos micro-sociológicos e os elementos subjetivos e simbólicos da experiência da procura de trabalho, com certeza muitas questões fundamentais sobre os mecanismos de (re)inserção no mercado de trabalho carecem de investigação. Exemplifica-se, indicando duas linhas possíveis de continuidade. Primeiro, como essa pesquisa se focou no estudo de uma situação de procura de trabalho delineada por instituições privadas de intermediação, não foi possível avançar no conhecimento sobre outras estratégias de procura. Com certeza seria relevante entender melhor a dinâmica social através da qual operam outras formas de procurar e obter trabalho. Além disso, seria 
pertinente compreender como se articulam diferentes estratégias de procura e investigar quais são aquelas mais eficientes para cada tipo de demandante.

Em segundo lugar, como foi possível identificar o peso que as interações e os julgamentos sociais têm no processo de convergência entre uma vaga e um candidato, a questão da discriminação e do preconceito nas seleções e recrutamentos se mostrou relevante e digna de continuidade. Foi possível captar alguns discursos dos funcionários das agências sobre características comportamentais e físicas (como peso e cor) dos candidatos que são determinantes dos processos seletivos, assim como percepções dos demandantes a este respeito . Porém, devido à pouca quantidade de material não foi possível avançar nesse caminho extremamente pertinente que poderia revelar mais sobre os elementos sociais que regem o processo econômico de procura e compõem o mercado de trabalho.

Esses, como outros exemplos que se poderia levantar, são vias de avanço no desvendamento de um tema cuja complexidade deriva não apenas do enredo multifacético que caracteriza a realidade, mas da notável falta de conhecimento sobre um processo - como o de buscar e obter trabalho - que se revela tão central, em nossos dias. Isso, tanto com respeito às políticas públicas, às formas de pacto e entendimento macro-social, como com respeito à experiência cotidiana dos indivíduos em contextos desafiados pela intensa e célere transformação socioeconômica e, sobretudo, dos meios de acesso e circulação de informações. 


\section{BIBLIOGRAFIA}

ALEXANDER, Jeffrey (1987) Twenty Lectures- Sociological theory since World War II, Columbia University Press, New York.

Sociais, no 4. pp.5-28.

(1987-b). "O novo movimento teórico". Revista Brasileira de Ciências

ALONSO, José Rojo (1991) A rua Barão de Itapetininga. Documento encomendado pela "Ação Local Barão de Itapetininga”. Mimeo.

AMADEO E. J. e DUTT, A. (1994) A teoria econômica do desemprego. São Paulo. Hucitec.

AMERICANO, Jorge. (1957) São Paulo naquele tempo: 1985- 1915. São Paulo. Ed. Saraiva.

ANELLI, Renato Luiz Sobral. (2005) "Calçadões Paulistanos - em debate o futuro das áreas de pedestres do centro de São Paulo” Arquitextos, São Paulo, v. 060, n. maio.

ANTUNES, Ricardo (1999) Os sentidos do trabalho. São Paulo. Boitempo Editorial, 6a edição.

ARANTES, Antônio A. (2000) Paisagens paulistanas: transformações do espaço público. Campinas. Editora da Unicamp.

BALTAR, P. E., PRONI, M. W. (1996) "Sobre o regime de trabalho no Brasil: rotatividade da mãode-obra, emprego formal e estrutura salarial". In: OLIVEIRA, C. A.; MATTOSO, J. (Orgs.) Crise e trabalho no Brasil. São Paulo, Scritta, pp. 109-149.

BARBOSA, Alexandre de Freitas e MORETTO, Amilton (1998). Políticas de Emprego e proteção Social. In: DEDECCA, C. (Org.) Coleção ABET - Mercado de trabalho, v.1. São Paulo. Associação Brasileira de Estudos do Trabalho - ABET.

BARLEY, Stephen, EVANS, James e KUNDA, Gideon (2002) "Why do contractors contract? The experience of highly technical professionals in a contigent labor market" in: Industrial and Labor Relations Review, vol, 55, No 2, pp. 234-261.

BECKER, Howard, MCCALL, Michael (1990). Symbolic Interacion and Culture Studies. Chicago. The University of Chicago Press.

BENHABIB, Jess, BULL, Clive (1983) "Job search: the choice of intensity", The Journal of Political Economy, vol. 91, no 5, pp. 747- 764.

BENOIT-GUILBOT, O. (1990)"La recherche d'emploi: stratégies, qualification scolaire ou professionnelle et qualification sociale”. Sociologie du travail, Paris, n. 4, p. 491-506.

BERGER, Bennett (1986). "Foreword” In: GOFFMAN, E. Frame Analysis, Boston.E. Northeastern University Press. 
BESSA, Vagner e CONSONI, Flávia (2007). "Mecanismos institucionalizados na procura de trabalho: como se configura o mercado de locação de mão-de-obra?”. In: GUIMARÃES, N. À procura de trabalho: Instituições de intermediação e redes sociais na saída do desemprego. São Paulo numa perspectiva comparada, Relatório de Pesquisa. Pp. 113-130. Disponível no site: www.centrodametropole.org.br .

BLUMER, Herbert (1969). Symbolic Interacionism. Perspective and method, New Jersey. Prentice Hall.

BORGES, Ângela. (2006) "Impactos do desemprego e da precarização sobre famílias metropolitanas". Revista brasileira de estudos populacionais. São Paulo, v. 23, n. 2, 2006, pp. 205-222.

BRANDÃO, S., WATANABE, M., FERREIRA, S., MONTAGNER, P. (2006) "Mobilidade ocupacional: a experiência da região metropolitana de São Paulo". In: GUIMARÃES, N., HIRATA, H. (Orgs). Desemprego: trajetórias, identidades, mobilizações. São Paulo, Editora Senac. pp. 91125.

BRANDÃO, S. \& HOFFMAN, M. (2006) Medição de emprego. Cadernos do CESIT., $\mathrm{n}^{\circ}$ 22, Campinas. IE/CESIT.

CACCIAMALI, Maria Cristina (2005). "As políticas ativas de mercado de trabalho no Mercosul. Tipos, sínteses de estudos de avaliação e reorientação". Revista do Instituto de Estudos Avançados, vol. 19 , no 55. pp. 85-104.

CACCIAMALI, Maria Cristina \& JOSÉ-SILVA, Maria de Fátima (2002). "Emprego e seguridade social: mais de uma década perdida no mercado de trabalho da América Latina". Paper apresentado nos Anales de la XV Conferencia de la Associacion de Faculdades, Escuelas e Institutos de Economia da América Latina. São Jose.

CAMPOS, NAKANO e ROLNIK (2004) "Dinâmicas dos subespaços da área central de São Paulo"In: COMIN, A., SOMEKH, N. (Org.) Caminhos para o Centro: estratégias de desenvolvimento para a região central de São Paulo. São Paulo. Empresa Municipal de Urbanização (EMURB), Prefeitura Municipal de São Paulo e Centro de Estudos da Metrópole (CEM). pp. 123-158.

CASTEL, Robert. (2005) As metamorfoses da questão social. Petrópolis. Editora Vozes.

CERQUEIRA, Monique Barbosa (2000). Os guardiões do tempo sobrevivem à cidade veloz: trabalho informal e saúde. Dimensões da exclusão social. Tese de mestrado apresentada ao Departamento de Sociologia, Unicamp.

CHAHAD, José Paulo Zeetano (2003) "Tendências recentes no mercado de trabalho: pesquisa de emprego e desemprego", São Paulo em Perspectiva, v.17 n.3-4, São Paulo, julho/dez, pp.205-217.

COLLINS, Randall (1994). Four sociological traditions, Oxford University Press. 
DAECTO, Marisa Midori (2002) Comércio e vida urbana na cidade de São Paulo (1889-1930). São Paulo.Editora Senac SP.

DEDECCA, Claudio Salvadori. (1996) "Racionalização econômica e heterogeneidade nas relações e nos mercados de trabalho no capitalismo avançado”. In: OLIVEIRA, C. A.; MATTOSO, J. (Orgs.) Crise e trabalho no Brasil. São Paulo: Scritta. pp. 55-85.

DEJOURS, Christophe (1987). A loucura do trabalho. São Paulo. Oboré Editorial.

DEMAZIÉRE, Didier (1995), La sociologie du chômage, Paris, Edition La Decouverte.

(2003) Le Chomage : Comment peut-être chomeur ?, Paris, Belin.

(2006) "Uma abordagem sociológica sobre a categoria do desemprego" In: GUIMARÃES, N., HIRATA, H. (Org). Desemprego: trajetórias, identidades, mobilizações. São Paulo. Editora Senac, SP. pp. 25-42.

DEMAZIÈRE, Didier, GUIMARÃES, Nadya A., SUGITA, Kurumi.(2006) Unemployment as a biographical experience. In: KASE, K., SUGITA, K. (Orgs.) The Unemployed and Unemployment in an International Perspective: Comparative Studies of Japan, France and Brasil, Tokyo, The University of Tokyo Institute of Social Sciences, ch. 4, pp. 68-148.

ECHEVERRÍA, M. (2001) In :XIMENA, D., EUGENIA, H. (Orgs.) Trabajo, flexibilidad y genero : tensiones de un proceso. Santiago. Centro de Estudios de la Mujer.

FINE, Gary Alan (1993) "The sad demise, mysterious disappearance and glorious triumph of symbolic interactionism”, Annual Review of Sociology, vol. 19, pp.61-87.

FOOTE-WHITE, Willian (2005) Sociedade de Esquina. São Paulo. Jorge Zahar.

FREYSSINET, Jacques. (1984), Le chômage, Paris, La Découverte.

FRÚGOLI, H. (1992) "Os shoppings de São Paulo e a trama do urbano: um olhar antropológico." In: PINTAUDI, S., FRÚGOLI, H. (Org.) Shoppings centers: Espaço, cultura e modernidade nas cidades brasileiras. São Paulo. Editora da Unesp, pp. 75-92.

Marco Zero.

(1995) São Paulo: espaços públicos e interação social. São Paulo. Editora

(2000) Centralidade em São Paulo: trajetórias, conflitos e negociações na cidade. São Paulo, Cortez/Edusp.

GEORGES, Isabel; JANEQUINE, Olívia (2007) "Onde a lei pega? Etnografia de uma agência privada de intermediação de mão-de-obra" In: GUIMARÃES, N. À procura de trabalho: Instituições de intermediação e redes sociais na saída do desemprego. São Paulo numa perspectiva comparada, Relatório de Pesquisa. pp.171-188 Disponível no site: www.centrodametropole.org.br . 
GOFFMAN, Erving (1961) Encounters: two studies in the sociology of interaction. Bobbs-Merril Company Inc, Indiana.

(1963). Behavior in public places. Notes on the social organization of gatherings. Free Press. New York.

(1964) "The neglected situation". American Anthropologist, New Series, Vol. 66, part 3: the ethnography of communication, pp 133-136.

(1982). Interaction ritual. Pantheon Books, New York.

(1983). A representação do eu na vida cotidiana, Editora Vozes, Petrópolis.

(1983-b) "The interaction order. American sociological Association, 1982 Presidential Adress." American Sociological Review, Vol. 48, nº 1, pp. 1-7.

(1988). Estigma. Notas sobre a manipulação da identidade deteriorada. Rio de Janeiro. Editora Guanabara.

(1986). Frame Analisys. Boston.Northeastern University Press

(2003). Manicômios, prisões e conventos. São Paulo. Perspectiva.

GRANOVETTER, Mark. (1973). "The strength of weak ties". American Journal of Sociology, Vol. 78, n. 6, pp.1361-1380.

University Press.

(1974). Getting a job - a study on contacts and careers. Cambridge, Harvard

GUIMARÃES, Laís de Barros Monteiro Samarão (2005). Centro Velho de São Paulo. São Paulo. Scor Editora Tecci,

GUIMARÃES, Nadya Araujo (2002) "Por uma sociologia do desemprego: contextos societais, construções normativas e experiências subjetivas". Revista Brasileira de Ciências Sociais, v. 17, São Paulo, pp. 103-122.

(2004) Caminhos Cruzados - Estratégias de Empresas $e$ Trajetórias de Trabalhadores, São Paulo, Editora 34 e Programa de Pós-Graduação em Sociologia.

(2006-a) "Flexibilizando o flexível: formas do trabalho sob o prisma do mercado de intermediação". Comunicação apresentada no Colóquio Internacional Novas formas do trabalho e do desemprego. Japão, França e Brasil numa perspectiva comparada realizado na Universidade de São Paulo (USP), São Paulo. 
(2006-b) Novas formas, novas medidas?: desemprego, trajetórias ocupacionais e experiências na produção de informações. São Paulo em Perspectiva, São Paulo, Fundação Seade, v. 20, n. 4, p. 103-126, out./dez. 2006. Disponível em:http://www.seade.gov.br; http://www.scielo.br.

(2007-a) À procura de trabalho: Instituições de intermediação e redes sociais na saída do desemprego. São Paulo numa perspectiva comparada, Relatório de Pesquisa disponível no site: www.centrodametropole.org.br

(2007-b) "À Procura de Trabalho: Desempregado, demandante de trabalho, candidato" In: GUIMARÃES, N. À procura de trabalho: Instituições de intermediação e redes sociais na saída do desemprego. São Paulo numa perspectiva comparada, Relatório de Pesquisa. pp. 252-281. Disponível no site: www.centrodametropole.org.br

(2007-c) "O sistema de intermediação de empregos. Um outro olhar sobre o mercado de trabalho da região metropolitana de São Paulo”. In: GUIMARÃES, N. À procura de trabalho: Instituições de intermediação e redes sociais na saída do desemprego. São Paulo numa perspectiva comparada, Relatório de Pesquisa. pp. 10-79. Disponível no site: www.centrodametropole.org.br

(2007-d) "Empresariando o trabalho: os agentes econômicos da intermediação de empregos, esses ilustres desconhecidos" In: GUIMARÃES, N. À procura de trabalho: Instituições de intermediação e redes sociais na saída do desemprego. São Paulo numa perspectiva comparada, Relatório de Pesquisa. pp. 80-112. Disponível no site: www.centrodametropole.org.br

(2009) À procura de trabalho. Instituições do mercado e redes. Belo Horizonte. Ed. Argvmentvm, CEM, IUPERJ.

Argvmentvm, CEM, IUPERJ.

(2009-b) Desemprego: Uma construção social. Belo Horizonte. Ed.

GUIMARÃES, Nadya; HIRATA，Helena; MONTAGNER，Paula; SUGITA，Kurumi (2004) "Desemprego - mercados, instituições e percepções: Brasil e Japão numa perspectiva comparada", Tempo Social, v.16, n² 2, São Paulo, pp. 257-287.

GUIMARÃES, Nadya \& MELO, Frederico (2008) "Quem recorre às instituições do mercado para encontrar trabalho?". Comunicação Encontro Nacional de Estudos Populacionais, Associação Brasileira de Estudos Populacionais, Caxambu, mimeo.

HAGUETTE, Teresa Maria Frota (1987) Metodologias qualitativas na Sociologia. Petrópolis. Editora Vozes. 
HIRANO, Luis Felipe Kojima (2007) “Currículo: embalagem do produto?”. In: GUIMARÃES, N. À procura de trabalho: Instituições de intermediação e redes sociais na saída do desemprego. São Paulo numa perspectiva comparada. Relatório de Pesquisa. pp. 189-228. Disponível no site: www.centrodametropole.org.br .

IPEA (2007) Boletim Políticas Sociais. Acompanhamento e Análise. 1995-2005. Edição Especial. Disponível em: www.ipea.gov.br

JOAS, Hans (1999) "Interacionismo simbólico" In: GIDDENS, A. \& TURNER, J. (Orgs.) Teoria Social Hoje. São Paulo. Editora da Unesp, pp.127-174.

JOSEPH, Isaac. (2000). Erving Goffman e a microssociologia. Rio de janeiro. Editora FGV.

KEYNES, Jonh. (1936) Teoria Geral do Emprego, do Juro e da Moeda. São Paulo. Abril Cultural, Coleção Grandes Cientistas Sociais, 1978.

KOENE, Bas e PURCELL, Kate (2004) "The value of relationships in a transactional labour market: constructing a market for temporary employment”, mimeo, não publicado.

LAHIRE, Bernard (2002) O Homem Plural: os determinantes da ação. Vozes. Petrópolis.

LAZARSFELD, Paul; YAHODA, Marie; ZEIZEL, Hans (1981). Les Chômeurs de Marienthal. Paris. Ed. De Minuit.

LEDRUT, R. (1966), Sociologie du chômage, Paris, PUF

LIPPMAN, Steven \& MCCALL, Jonh (1976) "The economics of job search", Economy Iquiry 14. pp. 155-189.

LUZ, Rogério Ribeiro da. (1999) Centro Velho de São Paulo: memória-momento. Massao Ohno Editor, São Paulo.

MAGNANI, José Guilherme (1996) "Quando o campo é a cidade: fazendo antropologia na metrópole” In: MAGNANI, J. G. (Org.) Na metrópole: textos de antropologia urbana. São Paulo. Edusp.

MAINES, David R. (1977) "Social Organization and Social Structure in Symbolic Interactionism Thought”, Annual Review of Sociology, Vol. 3, pp 235-259.

(1979) "Mesostructure and social process. Reviewed work: Negotiations: Varieties, contexts, processes and social order", Contemporary Sociology, Vol. 8, № 4, pp 524-527.

MALIN, Mauro. (1995) Memórias do Comércio. São Paulo. Editado por: FCESP, SESC, SENAC, SEBRAE.

MANKIW, N. Gregory (1995). Macroeconomia. São Paulo LTC Editora. 
MARQUES, Gabriel (1966). Ruas e tradições de São Paulo. São Paulo. Conselho Estadual de Cultura do Estado de São Paulo.

MARUANI, Margaret \& REYNAUD, Emmanuèle. (1993), Sociologie de l'emploi. Paris, Éditions La Decouverte (Collection Repéres, n. 132).

MEAD, George H. (1952) Mind, Self and Society. Chicago. The University of Chicago Press.

MUSOLF, Gil Richard (1992) "Structure, Institutions, Power and Ideology: new directions within symbolic interactionism” The Sociological Quarterly, Vol. 33, n² 2, pp. 171-189.

NUNES, Jordão Horta (2005) Interacionismo Simbólico e dramaturgia.A sociologia de Goffman .Associação Editorial Humanitas, São Paulo, Goiânia, Editora UFG.

OFFE, Claus (1989). "Trabalho: uma categoria-chave da sociologia?" in Revista Brasileira de Ciências Sociais, vol. 4, n. 10, junho de 1989, pp. 5-20

O’TOOLE, Richard (1979) "Reviewed Work: Negotiations: Varieties, contexts, processes and social order”, Social Forces, Vol. 58, No 2. pp. 693-684.

PAMPLONA, João Batista. (2002) "Estudo das empresas prestadoras de serviços de seleção, agenciamentos e locação de mão de obra temporária do Grande ABC Paulista.” In: GUIMARAES, LEITE, BENTO, SOARES. (Orgs.) Gestão local, empregabilidade e equidade de gênero e raça: um experimento de política pública na região do ABC Paulista. Relatório final, São Paulo, FAPESP/CEBRAP/ Prefeitura Municipal de Santo André/ CEERT/ ELAS, capt 19, disponível em: www.fflch.us.br/sociologia/nadya

PEDRO, Mônica Aparecida Varasquim (2007) “A intermediação de mão-de-obra numa grande organização: especificidades de uma empresa pioneira" in: GUIMARÃES, N. Á Procura de Trabalho: instituições de intermediação e redes sociais na saída do desemprego. São Paulo numa perspectiva comparada. Relatório de Pesquisa. pp. 148-170. Disponível no site: www.centrodametropole.org.br

PEIRANO, Mariza (1992) A favor da Antropologia. (Série Antropologia, 130). Brasília, Universidade de Brasília, Instituto de Ciências Humanas.

POCHMANN, Márcio (1999) O trabalho sob fogo cruzado. São Paulo, Contexto. (2007) O emprego na era da globalização. São Paulo. Boitempo.

RODARTE, M. M. S.; BRAGA, T. S. (2005) "Tendências recentes do Mercado de Trabalho no Brasil a partir da Pesquisa de Emprego e Desemprego (PED)". In: DIEESE/Cesit (Orgs.). $O$ trabalho no setor terciário - emprego e desenvolvimento tecnológico. São Paulo/Campinas DIEESE/ CESIT, pp. 67-94.

RODRIK, Dani. (1997) Has globalization gone too far?.Washington, DC. Institute for international Economics. 
SENNETT, Richard. (2003) A corrosão do caráter - conseqüências pessoais do trabalho no novo capitalismo. Rio de Janeiro, Record.

SINGER, Paul (2000) Globalização e desemprego: diagnóstico e alternativas. São Paulo. Contexto.

STINGLER, George (1961) “The economics of information”, Journal of Political Economy, Vol 69, pp. 213-225.

STRAUSS, Anselm (1979) Social words and spatial processes: an analyltic perspective. Department of Social and Behavioral Sciences. University of California, San Francisco. Disponível em: http://www.ucfs.edu/ansemstrauss

(1988) Negotiations: Varieties, Contexts, processes and Social Order. Califórnia. Jossey Bass Publishers.

(1999) Espelhos e máscaras. A busca da identidade. São Paulo.Edusp.

STRYKER, Sheldon (1987) "The vitalization of Symbolic Interactionism" in: Social Psychology Quarterly, Vol. 50, nº1, pp. 83-94.

TARTUCE, Gisela Lobo (2007) "Da escola ao trabalho: tensões e intenções dos jovens à procura de emprego em agências do Centro de São Paulo". In: GUIMARÃES, N. À procura de trabalho: Instituições de intermediação e redes sociais na saída do desemprego. São Paulo numa perspectiva comparada, Relatório de Pesquisa. pp. 313-353. Disponível no site: www.centrodametropole.org.br

(2007-b) Tensões e intenções na transição escola-trabalho. Um estudo das vivências e percepções de jovens sobre os processos de qualificação profissional e (re) inserção no mercado de trabalho na cidade de São Paulo. Tese de doutorado apresentada ao Programa de Pós -Graduação em Sociologia da USP.

TELLES, Vera da Silva. (2006) "Trajetórias urbanas: fios de uma descrição da cidade". In: CABANES, R., TELLES, V. (Org.) Nas tramas da cidade: trajetórias e seus territórios, São Paulo.Humanitas.

VELHO, Gilberto (1999) “Apresentação. Anselm Strauss: Indivíduo e Vida Social” In: STRAUSS, A. Espelhos e máscaras. A busca da identidade, São Paulo. Edusp.

VIEIRA, Priscila (2007) "O homem e a placa ou a placa e o homem: os homens-placa e a procura de trabalho no Centro". In: GUIMARÃES, N. À procura de trabalho: Instituições de intermediação e redes sociais na saída do desemprego. São Paulo numa perspectiva comparada, Relatório de Pesquisa, pp. 229-250. Disponível no site: www.centrodametropole.org.br .

VISHWANATH, Tara (1989) "Job search, Stigma effect and rate escape from unemployment", Journal of Labor Economics, vol. 7, $\mathrm{n}^{\circ}$ 4. pp.487-502. 
YOSHINAGA, Mário. (2004) "Infra estrutura urbana: ruas subterrâneas", Minha cidade ano 4, vol. 9, abril. São Paulo. pp.95.9595 4, vol. 9, abr. 2004, p. 095

WILLIANS, Simon Johnson (1986) “Appraising Goffman”, The British Journal of Sociology, Vol. 37, n 3, pp. 348-369.

ZUKIN, Sharon (2000) "Paisagens urbanas pós-modernas: mapeando cultura e poder", Pp. 81-103, In: ARANTES, A. (Org) O espaço da diferença, Campinas, Papirus.

\section{Sites consultados:}

www.sampa.art.br WWw.vivaocentro.org.br

www.sampacentro.terra.com.br

www.vivasp.com

www.saopaulominhacidade.com.br

WwW.oglobo.globo.com

www.fotoplus.com

www.centrodametropole.org.br

Www.prefeitura.sp.gov.br

www.seade.gov.br

www.ipea.gov.br

www.dieese.org.br

http://www.ucfs.edu/ansemstraus 


\section{ANEXO 1 \\ Índices}

\section{1. Índice de tabelas}

1.1: Distribuição das agências privadas da RMSP por porte e localização.

\section{2. Índice de figuras}

1.1.Evolução do Tempo Médio de Procura de Trabalho (em semanas) por tipo de desemprego na RMSP (1990-2008)

1.2. Onde moram os demandantes entrevistados no cluster de agências do Centro

3.1. Mapa da Região da Rua Barão de Itapetininga

3.2. Foto da Rua Barão de Itapetininga

3.3. Foto de anúncios de trabalho colados nas fachadas do comércio

3.4. Foto dos plaqueiros divulgando vagas na Rua Barão de Itapetininga

3.5. Demandantes de trabalho em fila

\section{3. Índice de quadros}

2.1.Distribuição das conversas por tipo de informante e local de abordagem (julho/agosto 2008)

2.2. Distribuição das entrevistas por tipo de informante (dez/2008 - mar/2009)

2.3. Temas comuns a todos os roteiros de entrevistas

2.4. Roteiro de entrevista aplicado aos funcionários das agências de emprego.

2.5. Distribuição de observações e entrevistas por agência analisada

2.6. Entrevistas com funcionários de Agências de Emprego (março/ 2009)

2.7. Roteiro de entrevistas aplicado aos estabelecimentos que ofertam serviços correlatos à procura

2.8. Distribuição de entrevistas e observações nos estabelecimentos que ofertam serviços conexos à procura por tipo de estabelecimento (janeiro/2009)

2.9. Entrevistas com funcionários dos estabelecimentos que ofertam serviços conexos à procura

2.10. Roteiro de entrevista aplicado aos plaqueiros 
2.11. Entrevistas com plaqueiros (Janeiro/2009)

2.12. Roteiro de entrevista aplicado aos demandantes de trabalho

2.13. Entrevistas com demandantes de trabalho (dezembro/2008-fevereiro/2009)

3.1.Características dos funcionários entrevistados nas agencias

3.2: Características das agências de emprego investigadas

3.3.Práticas e atividades dos plaqueiros entrevistados

4.1.Características dos demandantes do grupo "Em Busca do Primeiro Emprego"

4.2: Características dos demandantes do grupo de "Jovens adultos em busca de um bom emprego"

4.3: Características dos demandantes do grupo de "Jovens adultos em busca de um emprego com urgência"

4.4. Características dos demandantes do grupo dos "Adultos em busca de um novo emprego 